\title{
PROBLEMAS ACTUALES SOBRE DERECHOS HUMANOS
}

Una propuesta filosófica

JAVIER SALDAÑA SERRANO

Coordinador 
PROBLEMAS ACTUALES SOBRE DERECHOS HUMANOS

Una propuesta filosófica 


\section{INSTITUTO DE INVESTIGACIONES JURÍDICAS}

Serie E: VARIOS, núm. 88

\section{COORDINACIÓN EDITORIAL}

Lic. Raúl Márquez Romero

Secretario Técnico

Lic. Wendy Vanesa Rocha Cacho

Jefa del Departamento de Publicaciones

Javier Mendoza Villegas

Formación en computadora

Carlos Martín Aguilera Ortiz

Elaboración de portada 


\section{PROBLEMAS ACTUALES SOBRE \\ DERECHOS HUMANOS}

Una propuesta filosófica

JAVIER SALDAÑA

Coordinador
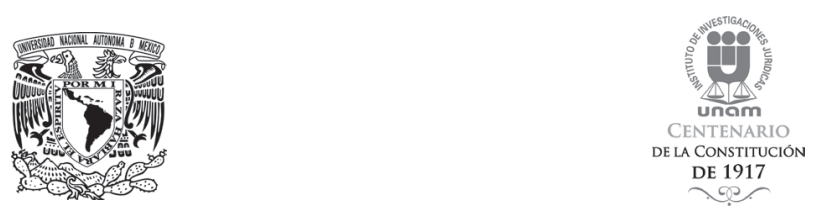

UNIVERSIDAD NACIONAL AUTÓNOMA DE MÉXICO INSTITUTO DE INVESTIGACIONES JURÍDICAS 
Primera edición: 1997

Primera reimpresión: 2000

Segunda reimpresión: 14 de diciembre de 2017

DR (C) 2017. Universidad Nacional Autónoma de México

\section{INSTITUTO DE INVESTIGACIONES JURÍDICAS}

Circuito Maestro Mario de la Cueva s/n

Ciudad de la Investigación en Humanidades

Ciudad Universitaria, 04510 Ciudad de México

Impreso y hecho en México

ISBN 978-968-36-6457-0 


\section{INTRODUCCIÓN}

Hal Foster comienza la introducción de The Anti-esthetic: Essays on Postmodern Culture preguntándose si en verdad existe el llamado posmodernismo y, si esto es así, qué significa realmente. Más adelante continúa interrogándose si éste es un concepto o una práctica; si es una cuestión de estilo local o todo un periodo de la historia o una nueva fase de la economía; ¿cuáles son sus formas — continúa diciendo—-, sus efectos y su lugar? ¿Se está verdaderamente más allá de la modernidad y por tanto en un época posindustrial? Estas preguntas no encuentran respuesta, más bien generan una mayor incertidumbre. Podríamos decir al final que esto es quizá lo que caracteriza a los tiempos que corren, los que desde diversos ángulos del pensamiento humano se han calificado bajo el nombre de posmodernidad.

En este sentido, la primera pregunta a formularse sería: ¿cuál es el significado real de la posmodernidad, al menos en sus aspectos más generales? Ésta, se nos dice, parece consistir esencialmente en una ruptura con la herencia cultural del mundo moderno y, sobre todo, en la puesta en evidencia de los excesos de la razón como instancia última del conocimiento y del pensar humano que los ilustrados franceses habían determinado como verdad absoluta; en definitiva, la innegable crisis de la razón de la que ahora la humanidad parece tomar conciencia. La posmodernidad es, como lo señaló el Frankfurter Allgemeine Zeitung, lo antimoderno.

Lo antimoderno fue inicialmente un movimiento que tuvo su origen en el terreno de la estética y que ahora describe — como lo señala Habermas- "una corriente emocional de nuestro tiempo que ha penetrado en todos los aspectos de la vida intelectual", ${ }^{1}$ presentándose como un fracaso de la modernidad y del paradigma que la sostuvo: el progreso humano como fatalmente inevitable.

Este progreso de lo "humano", esencialmente partía de lo económico y encontraba eco en lo político y religioso. En el aspecto económico, la pretendida prosperidad sería reflejada en una mejora cuantitativamente

1 AA. VV., "La modernidad, un proyecto incompleto", La posmodernidad, México, KairónColofón, 1988, pp. 19 y ss. 
Este obra forma parte del acervo de la Biblioteca Jurídica Virtual del Instituto de Investigaciones Jurídicas de la UNAM www.juridicas.unam.mx

https://biblio.juridicas.unam.mx/bjv

sustancial de las condiciones de vida individual, asegurada por la efectiva libertad de la circulación de las mercancías y el gradual aumento de la plusvalía comercial. En lo político, el progreso de las personas vendría dado, en primer lugar, por el reconocimiento de los derechos humanos, producto estos del iusnaturalismo racionalista y en el que el "individuo" sería primordialmente libre, pero sobre todo, esencialmente igual a todos los demás hombres, adquiriendo con ello la categoría superior de ciudadano de un Estado democrático en oposición al Estado estamental de la sociedad feudal. En segundo lugar, la construcción de la democracia como forma de gobierno en la que la participación ciudadana aseguraba la mejor y más próspera convivencia social a través de la participación política de sus miembros en la fundación del Estado liberal. Finalmente, por lo que al ámbito religioso respecta, era claro que el individuo "mejoraría" sus expectativas espirituales alejándose de la violencia y represión que fueron impuestas por el dogmatismo religioso medieval.

Los vicios que engendra llevar al extremo estos postulados es a lo que también renunciaría lo "antimoderno". Entre ellos, el excesivo economicismo que se observa en el sistema capitalista y que permea toda la realidad social trivializando lo que encuentra a su paso (en realidad ésta es la forma más sutil de alienación humana); la cada vez más preocupante destrucción del medio urbano y natural y de las diferentes formas de sociabilidad humana; la crisis de las estructuras que mantuvieron el estado liberal y el estado social de derecho y, sobre todo, la pérdida del sentido de trascendencia con la correspondiente negación de cualquier instancia superior a lo puramente humano. Éstas son, entre otras cosas, contra las que reaccionan, en mayor o menor medida, autores como Michel Foucault, ${ }^{2}$ Jürgen Habermas, ${ }^{3}$ K. O. Apel, ${ }^{4}$ etcétera, y los lleva a reconocer a los tiempos que corren como tiempos de decadencia.

2 Cfr. Foucalt, M., L'archeologie du savoir, París, Gallimard, 1969, passim; idem, A verdae e as formas jurídicas, Río de Janeiro, Pontificia Universidad Católica de Río de Janeiro, 1978, passim; Foucault, M., Chomsky, N., Reflexive Water. The Basic Concern of Humankind, London, Souvenir Press, 1974.

3 Cfr. Habermas, J., Der philosophische diskurs der moderne: zwölt vorlesungen, Suhrkamp Verlag, Frankfurt am Main, 1985, passim; idem, Nachmetaphysisches deken, Suhrkamp Verlag, Frankfurt am Main, 1988, passim; idem, "Über moralität und sittlichkeit- was macht eine lebensorm rational?", Rationalität, Suhrkamp Verlang, Frankfurt am Main, 1986; idem, "La modernidad, un proyecto incompleto", La posmodernidad..., op. cit., pp. 19-36.

4 Cfr. Apel, K. O., Transformation der philosophie, Suhrkamp Verlang, Frankfurt am Main, 1972, passim; idem, "Das problem einer philosophischen, theorie der rationalitätsypen”, Rationalität, Suhrkamp Verlang, Frankfurt am Main, 1984. 
Este obra forma parte del acervo de la Biblioteca Jurídica Virtual del Instituto de Investigaciones Jurídicas de la UNAM www.juridicas.unam.mx

https://biblio.juridicas.unam.mx/bjv

Sin embargo, a pesar de las evidencias expuestas como efecto de la crisis contemporánea, la posmodernidad y sus seguidores, los posmodernos, parecen encontrarse en un callejón sin salida y ante una evidente contradicción, pues a la vez que exponen los resultados ominosos de la modernidad de finales del siglo XX, intentan también volver a los temas importantes para el hombre a lo largo de su historia. Es salir del engaño ilustrado (tal y como lo califican los posmodernistas) y regresar a cuestiones trascendentales para el ser humano: problemas que buscarían, en términos de Foucault, "una nueva espiritualidad en el hombre"; una visión distinta y renovada de la democracia con verdadera y más amplia participación social; una forma diferente de concebir el progreso económico, como un mejoramiento más solidario y más social; 5 una concepción contraria hasta la ahora presentada para la explotación de los recursos naturales como una forma más racional de protección del medio ambiente, etcétera. Todo esto sustentado en el concepto de persona, que ni el poder económico ni el político podrían suplantar.

Esta otra posmodernidad llevada al terreno de lo jurídico, implicaría constitutivamente el cuestionamiento de la pretendida pureza de la ciencia jurídica ${ }^{6}$ de la mano, cada vez más evidente, de la estrecha relación entre el derecho y la moral dentro del decisionismo judicial, y que constituye, en definitiva, la puesta en jaque a la afirmación de que el derecho no es sino voluntad del poder, como lo había proclamado Hobbes. ${ }^{7}$ Esta visón de la posmodernidad es la que Ballesteros identifica como resistencia, la cual

5 Vid. Cómo uno de los autores más importantes del liberalismo contemporáneo como lo es Robert Nozick, va, sobre todo en su libro The Examined Life. Philosophical Meditations, del liberalismo más extremo de la década de los años ochenta a un liberalismo moderado, en el que el Estado ha de preocuparse más por los menos favorecidos de la sociedad. Cfr. Nozick, R., The Examined Life. Philosophical Meditations, 2a. ed., trad. cast. C. Gardini, Barcelona, Gedisa, 1992, passim.

6 Para un análisis más agudo del cuestionamiento de la ciencia jurídica en la posmodernidad cfr. D“Agostino, "La giustizia tra moderno e postmoderno”, Filosofia del diritto, Torino, G. Giappichelli, 1993, pp. 111-127; Ballesteros, J., "El cientificismo en la filosofía jurídica”, Sobre el sentido del derecho, 2a. ed., Madrid, Tecnos, 1986, pp. 19-62.

7 Bajo la expresión: "El legislador en todos los Estados es sólo el soberano, ya sea un hombre como en la monarquía, o en una asamblea de hombres como en una democracia o aristocracia. Porque legislador es el que hace la ley, y el Estado sólo prescribe y ordena la observancia de aquellas reglas que llamamos leyes: por tanto, el Estado es el legislador", se verifica la tesis moderna de que el derecho no es sino expresión de la voluntad de poder. Cfr. Thomas Hobbes, Leviathan or the Matter, Form and Power of Commonwealth Eclesiastical and Civil, trad. cast. M. Sánchez Sarto, México, FCE, 1994, pp. 217 y ss. 
Este obra forma parte del acervo de la Biblioteca Jurídica Virtual del Instituto de Investigaciones Jurídicas de la UNAM www.juridicas.unam.mx

sigue creyendo en la razón, en el progreso y en la democracia. Una razón integral y ampliada que se apoya en lo interdisciplinar y trata de satisfacer las necesidades humanas fundamentales, de lo biológico a lo simbólico [...] Un progreso como fruto del esfuerzo de la libertad humana, que parte de la convicción de que los grandes problemas de nuestro tiempo no son técnicos, sino éticos, y competen al homo qua homo. Una democracia que, lejos del etnocentrismo y del relativismo busca ante todo el respeto a lo inalienable en la persona tanto frente al Estado como frente al mercado. ${ }^{8}$

Encontrémonos o no en este final de siglo envueltos en la posmodernidad, en realidad es, quizá, lo menos relevante. De este ejercicio intelectual, lo verdaderamente significativo es que, independientemente de que hayamos superado los paradigmas vendidos por la modernidad (cosa de la que por otra parte yo no estoy seguro), hoy se tiene que observar una real preocupación por la persona y por sus problemas en sociedad, por el zoon politikon del que hablaba Aristóteles (Política, I, 2, 1253 a 2-3), en definitiva por un respeto de lo humano en lo social. Sin embargo, este cuidado por la persona no debe ser del estilo individualista, egoísta e insolidario como el que produjo la Ilustración francesa, sino una concepción por el hombre como persona, es decir, por el conjunto de relaciones en que se encuentra el hombre con los otros hombres o con las cosas, empleando la expresión de Kaufmann.

Lo antes expuesto en el derecho nos coloca inevitablemente ante la aceptación — como lo hemos señalado- de la estrecha relación que se observa en la nueva ciencia jurídica entre hecho y valor. Así, el derecho, y la reflexión sobre éste, ha de dirigirse necesariamente "al problema del derecho justo y finalmente hacia la justicia". ${ }^{9}$ Sin embargo, esto no podrá lograrse sin que antes se hayan superado los reduccionismos modernos a los que el positivismo jurídico ha llevado al derecho y que impiden captarlo en toda su realidad. ${ }^{10}$ En este sentido, el summ justum de los tiempos contemporáneos consiste, entre otras cosas, en lo que conocemos e identificamos como lo más esencial de la persona, sus derechos más esenciales, es decir, sus derechos humanos y los problemas realmente importantes que atañen al ser personal, y de los que en este volumen damos cuenta a continuación.

8 Ballesteros, J., Posmodernidad: decadencia o resistencia, Madrid, Tecnos, 1989, pp. 13-14.

9 Kaufmann, A., Rechtsphilosophie in der Nach-Neuzeit, 2a. ed., trad. cast. L. Villar Borda, Santa Fe de Bogotá, Temis, 1992, p. 38.

10 Cfr. Ballesteros, J., Sobre el sentido..., op. cit., p. 84. 


\section{Deberes jurídicos}

Habíamos señalado que uno de los temas importantes en la filosofía jurídica de hoy y que viene constituyéndose como esencial, es el relativo a la relación existente entre la ética y el derecho. Este es el punto de partida que trata de rescatar Jorge Adame al inicio de su trabajo, el cual aborda a partir del análisis de un elemento común a los tres conjuntos normativos (él incluye las leyes): la noción de deber. Deberes éticos, deberes políticos y deberes jurídicos.

Para alcanzar dicho objetivo, parte de un análisis fenomenológico de la persona humana, $\mathrm{y}$, sobre todo, de lo objetivamente conveniente a ella como el fundamento de todo deber, tanto ético como político y jurídico. Vale la pena aclarar que lo llamado por Adame como "objetivamente conveniente a la persona", no es sino la relación establecida entre la conducta libre y el perfeccionamiento de ésta. Es, como lo llama: la verdad ética o la verdad acerca del bien del hombre.

La explicación de los deberes éticos parte de un postulado fundamental: debes hacer esto, debes evitar esto otro; obra aquello que te perfecciona y evita lo que te degrada. Éste es el principio evidente que corresponde a la inclinación natural del hombre a ser feliz. De este modo, los deberes éticos fundamentales positivos son: deber de amor a uno mismo, el deber de amar al prójimo y el de amar a Dios. Correlativamente a estos corresponden los deberes negativos que son: la prohibición del homicidio, del robo, del adulterio y de la mentira.

Al lado de los deberes éticos se encuentran también los deberes políticos, es decir, aquellos cuyo cumplimiento interesa a la comunidad y que son básicamente el deber de colaboración en la consecución del bien comunitario, llamado también deber de solidaridad, y el deber de dar a cada uno lo suyo o deber de justicia. Estos deberes comunitarios se refieren a conductas necesarias o muy convenientes para el bien y conservación de la comunidad. De entre estos se distinguen los propiamente políticos, es decir, aquellos que se refieren específicamente al bien de la República, y que son los que se encuentran definidos en las leyes promulgadas y sancionadas por el poder público. Se reconoce también para estos deberes su origen eminentemente ético, o sea, son conducta adecuada al bien de la persona y de la comunidad.

Finalmente, los deberes jurídicamente exigibles, igual que los anteriores, provienen de un sustrato ético, y son aquellos cuyo cumplimiento 
Este obra forma parte del acervo de la Biblioteca Jurídica Virtual del Instituto de Investigaciones Jurídicas de la UNAM www.juridicas.unam.mx

es exigido ante un órgano jurisdiccional. Su rasgo característico es la posibilidad de su reclamación judicial. Así, tanto el análisis de los deberes éticos, como los políticos y los jurídicos, demuestran claramente la relación entre lo jurídico y lo moral. Implícitamente se reconoce a la persona como la cúspide en la pirámide de las ciencias prácticas.

\section{Una propuesta para fundamentar los derechos humanos}

La tesis que propone Aguayo sobre el pensamiento de Mauricio Beuchot viene a confirmar la idea que otros autores ya habían señalado acerca del nuevo planteamiento que sobre el derecho natural y los derechos humanos se viene dando en México. En este sentido, dentro de los muchos datos que podemos destacar del pensamiento filosófico de Beuchot, uno de los más relevantes tiene que ver con la defensa del derecho natural y particularmente del concepto de naturaleza humana desde postulados de filosofía analítica. Lo anterior parece quedar perfectamente explicado en dos de su libros (Filosofía y derechos humanos, y Derechos humanos. Iuspositivismo. Iusnaturalismo), de los que da cuenta el profesor Aguayo. En estos mismos podemos perfectamente observar cómo desde postulados analíticos es posible defender la naturaleza humana, los conceptos del derecho natural clásico, y, por tanto, los derechos humanos.

\section{Universalidad en los derechos}

Mauricio Beuchot aborda en su trabajo uno de los problemas más importantes en el campo de los derechos humanos: el problema de su universalidad. ¿Cuál es el fundamento de esta universalidad?, ¿cómo puede legitimarse cognoscitivamente el que no estén sujetos a ser particularizados o relativizados a algún contexto dado? Ante el escepticismo de autores como Rorty, Lyotard, Vattimo, etcétera, Beuchot propone una universalización que respete las diferencias de los hombres y culturas, y al mismo tiempo alcance la igualdad que sea posible lograr: una universalización analógica que consiste en congregar cognoscitivamente varios elementos respetando sus diferencias principales. Dicha postura es tomada de Aristóteles de su idea de la predicación o atribución pros hen, esto es, según algo uno es primero, y que se realiza proporcionalmente en los sujetos a los que se aplica. Desde la posición de Beuchot, es posible trabajar en la actualidad con el pensamiento antiguo, de manera que a partir de 
Este obra forma parte del acervo de la Biblioteca Jurídica Virtual del Instituto de Investigaciones Jurídicas de la UNAM www.juridicas.unam.mx

esto se pueda llegar a un tipo de universal diferenciado, que exige matización, que presenta y exhibe la distinción, y que también permite un ánimo de uniformidad suficiente, de manera que no invalida las diferencias.

Lo anterior lo lleva a la búsqueda de un fundamento a la universalidad de los derechos humanos, señalando que es posible ofrecer un fundamento de estos derechos en una utilización moderada, matizada y contextuada de la razón, un fundamento analógico. En efecto - como lo señala-, hay que moderar muchas cosas que se han hecho en la fundamentación de los derechos humanos; por ejemplo, la solidaridad o fraternidad, la cual ha quedado, en los tiempos modernos, relegada a un segundo plano o casi olvidada, detrás de la libertad y de la igualdad. La fraternidad llevará, en la medida en que se logre equilibrar la igualdad y la libertad a lo que Beuchot llama equidad analógica proporcional.

La universalidad analógica tiene mucho de semejanza con lo que Wolfgang Huber ha denominado "universalidad relativa". Esta última coincide con la analogía en su intención de respetar las características principales de los elementos del conjunto, los particulares de ese universal. Es una posición intermedia, que, sin perder la consideración de las diferencias, permita lo máximo de universalidad. Así, la tensión presentada entre lo universal y lo particular se equilibra no postulando que es algo que se va acordando en cada contexto, y por eso se hace universal, sino que se va acordando en cada contexto precisamente porque es universal. Bajo esta perspectiva, según lo manifiesta, se logrará una universalidad por el interés del otro, en los otros, en los muchos, en los más. Es, en definitiva, una universalización apoyada en la solidaridad, en aquello que antes era denominado bajo el calificativo de bien común, más allá de la sola preocupación por el bien individual.

\section{Igualdad y simetría}

Por su parte, Carpintero reconoce que los derechos clásicos de la modernidad son la libertad, la igualdad y el derecho individual de propiedad, aunque este último es poco probable que se contemple hoy como un derecho esencial básico. En cambio, lo que sí ha permanecido es la exigencia de igual libertad individual desde la que parece ha de partir hoy la teoría de la justicia. Sin embargo, ¿es posible que esta idea pueda dar respuestas a las interrogantes que plantean otras ramas del derecho? 
Este obra forma parte del acervo de la Biblioteca Jurídica Virtual del Instituto de Investigaciones Jurídicas de la UNAM www.juridicas.unam.mx

Para Carpintero, el análisis de esta cuestión ha de partir de una ética dialógica, es decir, de aquella ética que necesariamente reposa sobre la generalización propia del imperativo categórico kantiano. En este sentido, los nuevos sistemas de ética observan a la razón como una simple función que surge desde la conjunción de las libertades personales con los intereses igualmente individuales. Esta nueva razón que habita en el lenguaje, ha propuesto desde el siglo XVIII hasta hoy una ética utilitarista que desconoce la justicia. Prescindir de esta idea y erigir a unas utilidades en el verdadero rostro de la justicia es prescindir de lo más humano. Y el hombre no se entiende si se prescinde de lo humano.

Después de hacer un análisis de algunos rasgos del pensamiento kantiano, señala que parece mejor descartar la "posibilidad siempre presente" de trasladar "la generalidad del imperativo categórico kantiano" a la justicia que hace las leyes o las sentencias, para conocer la justicia de cada caso. Porque desconoce la singularidad de cada ser humano, y porque no tiene en cuenta la humanidad del hombre, que es más que un cazador de cosas para ser feliz.

\section{Derechos y deberes}

Los tiempos actuales reflejan una clara confianza en los derechos humanos, esto lo señala D’Agostino, y nos dice también que ésta se revela como verdadera "corriente candente" capaz de convertir el pensamiento en praxis y de escribir una página nueva en la historia de la humanidad. Así, el nuevo derecho internacional parece descubrir en el concepto de dignidad de la persona su nuevo objetivo, su nuevo centro de gravedad. En resumen, los derechos humanos representan realmente una revolución cultural de incalculables proposiciones. Sin embargo — nos advierte el profesor- esto no quiere decir que haya que asumir posiciones triunfalistas, antes hay que salvar una serie de problemas que plantean los mismos derechos humanos. ¿Por qué los derechos humanos son en gran parte irrealizables, defectuosos, incluso en aquellos ordenamientos que los han constitucionalizado? A tal interrogante no es fácil responder, ya que existen motivos históricos bien determinados de las violaciones de estos derechos en cada país. Sin embargo, se podrían señalar algunas de las dificultades que presenta la real observancia de estos mismos. Una de estas es la que se refiere a los límites políticos de los derechos del hombre; otra es de carácter estructural, que se atiene a la lógica puramente jurídica y que 
Este obra forma parte del acervo de la Biblioteca Jurídica Virtual del Instituto de Investigaciones Jurídicas de la UNAM www.juridicas.unam.mx

se refleja en el signo de la maximización de la libertad de todos, donde los derechos de unos pueden entrar en colisión con los derechos de los otros. Esta dificultad nace de confundir el estatuto específico del conflicto de derecho con el de valores. Es un conflicto entre opuestas pretensiones jurídicas subjetivas y no entre valores opuestos. El problema puede ser resuelto si acudimos al criterio de universalidad.

Otro problema igual de importante que los anteriores es el que tiene que ver con el excesivo aumento de cartas y documentos protectores de derechos humanos. Que en los últimos tiempos exista esta inadecuada proliferación es un síntoma de crisis. En este sentido, la mejor vía para defender los derechos humanos es a través de la conciencia que todos deben contribuir a defender, que el hombre sea garantizado verdaderamente. Sólo cuando todos los derechos que se le reconocen sean reducidos a un único y estable fundamento: el derecho de tener derecho.

$\mathrm{Al}$ referirse finalmente a los deberes, D'Agostino se pregunta si existen deberes fundamentales, respondiéndose afirmativamente. Lo esencial de la fórmula deberes fundamentales es la calificación de fundamental. Lo fundamental es, no porque sea dotado de importancia, sino al contrario: es de verdad importante sólo lo que es fundamental, porque no tiene otro fundamento que sí mismo. El deber fundamental es una deuda que no puede no ser pagada. Pero, ¿estos deberes fundamentales, en un discurso análogo, podrían ser hechos para los derechos fundamentales? D'Agostino señala que si el deber fundamental es aquello en el que coincide el Sein y Sollen, también el derecho fundamental debe ser clarificado en modo análogo, y se llama entonces fundamental a aquel derecho que, inherente a tal punto al hombre, que nunca puede ser sustraído de aquel derecho que constituye el fundamento de una pretensión subjetiva tal, de no poder no ser en cualquier modo satisfecha.

\section{Derecho y derechos humanos}

La reflexión que hace Huidobro parte del sentido que tiene la expresión derechos humanos y de los límites de los acuerdos prácticos recogidos en la base de las declaraciones de derechos del siglo XX. En este sentido comienza preguntándose sobre la titularidad del derecho: ¿qué significa ser titular de un derecho? Parece claro: la titularidad de un derecho humano, y de cualquier derecho en general, radica en el título que se tiene sobre él; es decir, en aquello por virtud de lo cual el derecho perte- 
Este obra forma parte del acervo de la Biblioteca Jurídica Virtual del Instituto de Investigaciones Jurídicas de la UNAM www.juridicas.unam.mx

nece o está atribuido a una persona y que por tanto a ésta misma le es debida. Y a todo esto ¿qué entendemos por derechos humanos? Se sabe que cuando se habla de derechos humanos, dicha expresión hace una referencia necesaria al hombre. Claros ejemplos de esto son las declaraciones de Virginia de 1776 y la francesa de 1789. Cuando hablamos de derechos humanos los distinguimos de los derechos positivos, es decir, de aquellos que el Estado asigna. De este modo — continúa el profesor chileno- los derechos humanos denotan ciertas cosas o atributos que corresponden a todo individuo de la especie humana. Así, estos derechos no serían más que la expresión jurídica y política de la dignidad humana, y ella no se posee por lo que se haya hecho o tenga, sino por lo que se es: hombre.

Continuando con las preguntas, Huidobro se formula las siguientes interrogantes: ¿por qué hay que respetar los derechos humanos?, ¿será acaso que el acuerdo sobre el qué de los derechos sea más importante al porqué del consenso llegado en 1948? Algo parece evidente: el porqué ha contribuido a consolidar una voluntad de respeto de los derechos humanos, aunque sigan existiendo problemas de tipo jurídico y político, junto a otros, que son difíciles de resolver. Sin embargo, parece que la concepción de una idea de bien podría ayudar a resolver algunos conflictos que presentan los derechos humanos. Así — como lo señala-, los principios de derechos humanos tal como se recogen en diversos textos internacionales constituyen directrices de acción, criterios de legitimidad y reglas de solución de conflictos, que parecen razonables a hombres de diversa procedencia. Reconociendo la problemática teórica que implica la aceptación de las distintas declaraciones de derechos y el apremio, cada vez más urgente, de su efectiva garantía, hoy resulta cada vez más imprescindible intentar comprender mejor qué es el hombre, pues en la medida en que se entienda éste, podremos saber qué es lo humano e inhumano en el entramado social.

\section{Los derechos humanos en la filosofía política}

Si alguna ganancia hemos de extraer del siglo que ahora termina, ésta ha de ser necesariamente la preocupación cada vez más constante por la protección de los derechos humanos. Ésta es la afirmación con la que comienza su trabajo la profesora Herrero, el cual desarrolla en tres apartados principales: la delimitación conceptual de estos; el significado de lo que ha de entenderse por intervención, y su relación con los derechos hu- 
manos; y un análisis del orden político definido desde el momento en que aparece la defensa de estos derechos.

La conceptuación de los derechos humanos presenta dos dificultades: es una expresión ambigua y es sumamente cuestionada a la hora de interpretarlos. En todo caso, parece que esta expresión denota una serie de derechos arraigados en la naturaleza de la persona y que reflejan exigencias objetivas e inviolables de una ley universal. Visto desde otro ángulo el problema de la conceptuación, los derechos humanos pueden parecer como un estadio intermedio entre el derecho natural, el derecho de gentes y el derecho positivo. No son ninguna de las tres cosas y son las tres a la vez.

Otro problema que los derechos humanos plantean es el que tiene que ver con el concepto de intervención. Ésta hace siempre referencia al uso de la fuerza, y es aceptada en derecho internacional como justificación en el supuesto de la violación de los derechos humanos, considerándose a estos mismos como una tarea moral en el ámbito internacional. Sin embargo, aun en los supuestos en los que se posibilita la intervención, se puede observar en estos motivos de carácter político, que hacen depender la decisión final de la intervención en el criterio de la ONU; ¿la Organización de las Naciones Unidas no puede violar los derechos humanos? Esto plantea un tercer problema para los derechos humanos, que parece irrenunciable: el tema del universalismo y particularismo; ¿pueden o no convivir estos dos órdenes? A esta pregunta responde que hoy parece que es difícil que se pueda dar tal supuesto. De este modo, termina señalando que la conquista de la paz mundial ha de fundarse en un orden de paz. Frente a la utopía del universalismo liberal se sitúa una teoría pluralista, para lo cual el logro de la paz sólo es posible mediante el desarrollo de una medida para la relación entre diversas unidades políticas que no hacen más que expresar el pluralismo de la vida del espíritu. Tales relaciones han de quedar recogidas en una ordenación jurídica internacional.

\section{Derechos humanos y crisis social}

Dentro de la compleja problemática que plantean los derechos humanos, parece necesario acudir a las causas que originan la actual preocupación por la eficaz protección de los derechos humanos. Parece que éstas pueden ser encontradas en la crisis actual de la sociedad, la cual es palpable en los distintos ámbitos del quehacer humano. El enjuiciamiento de la 
Este obra forma parte del acervo de la Biblioteca Jurídica Virtual del Instituto de Investigaciones Jurídicas de la UNAM www.juridicas.unam.mx

sociedad actual, es el punto del que parte la profesora Ilva Hoyos en su análisis sobre los derechos humanos. Para tal cuestionamiento comencemos por aceptar que en la sociedad contemporánea existe una diferenciación entre la pluralidad y el pluralismo (características ambas de dicha sociedad). Mientras la pluralidad reconoce la diversidad de individuos por un fin común y por la actividad también común de alcanzarlo, el pluralismo es expresión de un relativismo, es una actitud que reduce la verdad a la opinión, la certeza a un placer, los bienes a estimaciones subjetivas. En el pluralismo no hay nada bueno ni malo: todo es aceptable o es la mayoría la que determina qué es aquello que debe realizarse en determinada situación.

Así, la sociedad pluralista es aquella que está dominada por una mentalidad pluralista en la que se considera que cualquier idea, convicción o creencia es igualmente deseable en sociedad, sin que importe su contenido ni su referencia a un criterio de verdad. Así las cosas, es lógico que la causa de la crisis en la sociedad actual sea la pérdida teórica y práctica del respeto a la dignidad de la persona humana. Tal y como lo señala la profesora, la crisis de la época actual radica en la desorientación sobre el ser personal; pero como la persona vive en sociedad, esa desorientación también abarca al ser mismo de la sociedad. En el terreno de los derechos humanos y de la justicia en general, esta crisis se evidencia en la ruptura de un orden, el de la lesión no primariamente de normas, valores o estimaciones, sino la lesión de los bienes debidos a la persona y por ende el desconocimiento de la misma dignidad de la persona.

Así, parece entonces que es necesario reconocer la necesidad de una recuperación del concepto de persona y de su juridicidad natural. Por esta última se reconoce que existen derechos con una precedencia anterior a la ley positiva. Esta juridicidad natural y los derechos que contiene son lo que se predica de la persona, de su ser, de su dignidad. De esta manera, los derechos humanos son la expresión jurídica de la dignidad de la persona, dignidad que tiene relación con el ser con los fines. Fuera del orden, del ser y de los fines no puede haber derecho que se califique como humano; sólo injusticia, y, en cuanto tal, desconocimiento de la dignidad de la persona.

Finaliza la profesora diciendo que habrá que reconocer que los derechos humanos como expresión dinámica de la dignidad de la persona humana son algo más que lo que quiere cierto humanismo, que lleva a un relativismo y permisivismo, son las manifestaciones de las exigencias que 
Este obra forma parte del acervo de la Biblioteca Jurídica Virtual del Instituto de Investigaciones Jurídicas de la UNAM www.juridicas.unam.mx

https://biblio.juridicas.unam.mx/bjv

surgen de su propio ser. Así, pues, en esta época de crisis moral los derechos humanos deben reivindicarse como una recuperación no sólo teórica, sino también práctica de la dignidad de la persona humana.

\section{El derecho a la vida y los derechos humanos}

El profesor argentino Carlos Ignacio Massini aborda la problemática filosófica de uno de los derechos humanos más importantes: el derecho a la vida. Todo derecho presupone cuatro elementos: los sujetos (titular y obligado), la pretensión y el fundamento. En el caso de los derechos humanos, este último es la dignidad personal de todo ente humano. Estos derechos son entonces aquellos cuyo fundamento o justificación objetiva, tanto mediata como inmediata, se vincula al carácter personal del viviente humano y a la dignidad que corresponde a toda persona, y que no dependen esencialmente de su reconocimiento por los ordenamientos jurídicopositivos. Existen, incluso, aunque un ordenamiento los niegue o desconozca. Con estas premisas, define a los derechos humanos como aquellos derechos subjetivos cuyo título radica en la personeidad de su sujeto activo, o en alguna de las dimensiones básicas del desenvolvimiento de esa personeidad y de los que se es titular, los reconozca o no el ordenamiento jurídico positivo y aun cuando éste los niegue.

De esta manera, el contenido de los derechos humanos, como lo señala la Escuela de Derecho Natural inglesa, viene dado por los bienes humanos básicos que orientan la conducta de los hombres a su perfección como personas. Así, cada derecho humano se ordena a la realización de uno o varios bienes humanos básicos y recibe a su vez de éstos su justificación objetiva. En el caso concreto del derecho a la vida, éste tiene su fundamento racional en la dignidad de la persona, y su contenido está dado por el bien básico, que es la vida o existencia de los entes humanos. Este derecho ha de perdurar durante todo el tiempo de persistencia del bien que está destinado a proteger, es decir, la vida humana, y, por lo tanto, desde la concepción hasta la muerte. Del mismo modo, el derecho a la inviolabilidad de la vida — como lo llama el profesor Massini- se tiene o no se tiene. Es un derecho que no admite grados, no puede tenerse poco, o más o menos, o mucho. El derecho a la vida no puede ser nunca sobrepasado o suspendido por un principio de utilidad o de convivencia porque se trata, como el resto de los derechos humanos, de exigencias basadas en principios morales absolutos, es decir, inexcepcionales, que 
Este obra forma parte del acervo de la Biblioteca Jurídica Virtual del Instituto de Investigaciones Jurídicas de la UNAM www.juridicas.unam.mx

valen siempre y para siempre. Estos principios impiden, si se violan, la realización de un bien humano básico o principal, como puede ser la vida. Y es — como lo señala Massini-, por el carácter decisivo del impedimento y por la principalidad del bien atacado, por lo que son principios; normas que valen sin excepción, es decir, de un modo absoluto.

Finalmente, el profesor argentino termina señalando que las afirmaciones anteriores se oponen frontalmente al decidido antihumanismo, con el consiguiente menosprecio de la vida humana que caracteriza a buena parte del pensamiento actual. Este antihumanismo no es sino una necesaria consecuencia del inmanentismo y antitrascendentalismo del pensamiento tardomoderno y posmoderno, que niega la posibilidad de acceder al conocimiento de la realidad en sí y, por lo tanto, al absoluto que lo fundamenta.

\section{Utopía y tópicos en los derechos humanos}

En líneas parecidas a las apuntadas anteriormente, Ollero reconoce que la lucha por los derechos humanos aparece históricamente con caracteres de utopía social, la cual corre el riesgo de convertirse en tópico, es decir, en punto final de una utopía autosatisfecha; erigiéndose así en nido de gérmenes de su posible degeneración que pueden estar cumpliendo una función negativa para los derechos humanos, presentando como indiscutibles determinadas versiones de lo humano o descalificando, sin juicio previo, alternativas frente a las que no parece disponerse de argumentación.

Los tópicos antes descritos son los que Ollero denomina como tópicos al servicio de una utopía clandestina, entre los que encontramos: "las exigencias de la realidad social", cuyo riesgo es el de convertir las circunstancias sociales en criterios éticos indiscutibles. Otro es el de "las exigencias del progreso científico". Donde la dimensión cualitativa de la ética se ve suplantada por la conversión de lo cuantitativo en criterio supremo. Uno más es el "consenso social". Por último, los que enuncia al final son: "no imponer las propias convicciones a los demás" y "el pluralismo no confesional".

Ollero propone como forma de salvar de los tópicos a la utopía, en forma breve, lo siguiente: buscar detrás de cada alusión tópica su trasfondo antropológico; convertir en alusión tópica obligada las exigencias solidarias de los derechos humanos; dar paso a un uso reflexivo del ordena- 
miento jurídico que ayude a recordar que la pasividad ante los derechos humanos equivale a su traición; abatir la cotidiana tópica jurídica, mediante una transparencia argumental que permita convertirla en una utopía atesoradora de exigencias de lo humano.

\section{Los derechos humanos y el liberalismo}

Una de las críticas más importantes que han recibido los derechos humanos (principalmente los que conocemos como económicos, sociales y culturales), provienen del liberalismo, o, para hablar con más propiedad, del neoliberalismo, en cualquiera de sus especies. Sin embargo, valdría la pena reflexionar — como lo hace la profesora Velarde - acerca del espíritu que animó las primeras declaraciones de derechos. En este sentido, parece obligado identificar lo aún vigente de dicho espíritu inspirador en la concepción actual de los derechos humanos. De este modo, la primera cosa que debemos tener clara es la puesta en entredicho del proyecto liberal ilustrado, el cual descansaba en el acuerdo generalizado que reconocía una supuesta legitimidad democrática y en la noción de los derechos humanos; ambos, pilares del sistema liberal hoy en crisis y que necesitan ser sometidos a revisión. Desde el punto de vista de la ciencia del derecho, el carácter definidor de ésta es el de tratarse de una noción que se funda en una visión personalista del derecho en lugar de realista. El centro de atención no es la cosa sino la persona a la que le es debida, o, mejor aún, las vías de que dispone para la reclamación de esa deuda. En el plano político, los derechos se reducen a poderes de los individuos frente al poder soberano del gobernante, insistiendo particularmente, como característica de la Ilustración, en poner por escrito la relación de características del individuo humano que han de ser respetadas por todos los demás.

Parece, entonces, que dos de los intentos de respuesta a los problemas que plantean hoy los derechos humanos vienen dados por la confrontación univesalismo vs. comunitarismo con las matizaciones y precisiones de cada uno de ellos. Autores como Nagel, Gewirth, Rorty, Charles Taylor, Sandel, MacIntyre, reconocen la existencia de una serie de situaciones en el terreno de los derechos humanos de difícil solución. En todo caso, uno de los más importantes temas sobre estos mismos es el del contenido de los derechos. En este sentido, para abordar la cuestión del contenido de estos derechos habría que partir del nivel de conocimiento científico en el que la noción de derecho ha de ser desarrollada. 
Este obra forma parte del acervo de la Biblioteca Jurídica Virtual del Instituto de Investigaciones Jurídicas de la UNAM www.juridicas.unam.mx

Y lo primero a analizar es si estamos en presencia de una categoría moral o jurídica. En cualquier caso, por lo que hace a estos derechos, convendría señalar que si no es posible determinar lo que sea justo para todos los hombres de todos los tiempos sí lo es en cambio la determinación de cuál sea la conducta aquí y ahora. Ciertamente, el lenguaje jurídico no ofrece una sola respuesta para los problemas con que la razón práctica se enfrenta. En cambio, sí es posible delimitar lo que no puede ser considerado derecho. Como lo afirma la profesora Velarde, no es posible determinar $a$ priori el contenido de los derechos, y sí, en cambio, lo que sea justo en cada caso concreto, aunque la misma naturaleza, no sólo práctica sino instrumental del derecho, permite que ordinariamente las soluciones sean más de una.

\section{El consenso y los derechos humanos}

Uno de los tópicos anunciados anteriormente es el del consenso social, el cual no parece ser el que mejor resuelva el problema de la fundamentación de los derechos humanos. De este modo, si queremos tomarnos en serio los derechos (utilizando la expresión de Dworkin) y la fundamentación de éstos, tendremos que comenzar aceptando que ésta nos determina perfectamente lo que de objetivo hay en ellos, es decir, de aquellos datos evidentes, y qué de ideología en estos mismos. Parece claro que esa realidad objetiva a la que nosotros apelamos, puede ser el primer dato al que acudir para comenzar a buscar la respuesta al problema, siempre presente, del fundamento de los derechos humanos, por más que se insista en la pérdida de tiempo que implica esta labor filosófica.

\section{Agradecimientos}

La revisión que hemos hecho de los trabajos precedentes está muy lejos de agotar el contenido y riqueza de cada uno de ellos. Sin embargo, hemos querido hacer notar los puntos más significativos de los mismos bajo el riesgo, siempre constante, de trivializarlos. Mil disculpas...

Con esta aclaración que tranquiliza mi conciencia, no me resta más que agradecer a quienes colaboran en este trabajo, el apoyo brindado para la elaboración del mismo; a los colegas y amigos del Instituto de Investigaciones Jurídicas de la UNAM y, en especial, a su director, José Luis Soberanes, la constante preocupación por el estudio y difusión de los de- 
rechos humanos en la cultura jurídica mexicana. En forma personal, a Hugo Saúl Ramírez García por su empeñosa participación en la preparación del presente volumen.

Javier SALDAÑA SERRANO

Ciudad Universitaria, abril de 1997 


\title{
ÉTICA, LEGISLACIÓN Y DERECHO
}

\author{
Jorge ADAME GODDARD
}

SUMARIO: I. Introducción. II. El fundamento del deber. III. Los deberes éticos. IV. Los deberes políticos. V. Los deberes jurídicos. VI. Proposiciones.

\section{INTRODUCCIÓN}

La amplia cuestión de las relaciones entre la ética, las leyes y el derecho es hoy, en mi opinión, un problema central para el desarrollo del derecho y de la sociedad mexicana. Comprende preguntas tan acuciantes como estas: ¿deben las leyes respetar las tradiciones éticas de la sociedad, o pueden contradecirlas?, ¿deben las tradiciones éticas convertirse en leyes para ser respetadas o pueden y deben sobrevivir sin ser normas legisladas?, ¿tienen los ciudadanos el deber de obedecer leyes que violentan sus convicciones éticas o, por el contrario, tienen el deber de desobedecer las leyes? ${ }^{1}$

El tema es muy complejo, por lo que pretender abordarlo en su totalidad en un artículo sería totalmente inadecuado. En este trabajo sólo pretendo examinarlo a partir del análisis de un elemento que es común a los tres conjuntos normativos: la noción del deber. Parto de una premisa que es la afirmación de que el fundamento o razón del deber es único, tanto para los deberes éticos como para los deberes previstos en las leyes y para los sancionados jurídicamente. Por eso, en primer lugar, intentaré explicar y fundamentar dicha afirmación, a partir de un análisis fenomenológico de la persona humana (epígrafe II). Luego, con base en esa premisa, procederé a analizar brevemente la naturaleza de los deberes éticos (III), de los deberes señalados por las leyes a los que llamo deberes políticos (IV) y

1 Este problema se presenta hoy de manera más compleja dado el actual pluralismo ético y religioso de muchas de las sociedades occidentales. En México, se tiende hacia un pluralismo así, aunque aún sigue habiendo una considerable mayoría de la población que sigue las tradiciones éticas y la fe cristiana. 
Este obra forma parte del acervo de la Biblioteca Jurídica Virtual del Instituto de Investigaciones Jurídicas de la UNAM www.juridicas.unam.mx

de los deberes jurídicamente exigibles (V). Concluyo (VI) haciendo una exposición sintética de mi pensamiento sobre el tema en tres proposiciones.

A primera vista, advertirá el lector que separo la legislación del derecho, ya que considero, siguiendo en esto a Álvaro d'Ors, ${ }^{2}$ que las leyes, como mandatos del poder público, son órdenes, actos y obra de la voluntad, mientras que el derecho, que en parte está recogido en las leyes, ${ }^{3}$ lo constituyen básicamente criterios racionales o reglas para juzgar la conducta humana desde el punto de vista de lo justo, por lo que es principalmente obra de la razón. Esta distinción — que no es aquí el momento de analizarla - resulta muy útil, como constatará el lector, para el examen del problema que aquí nos ocupa.

Debo advertir que este trabajo es un primer intento de organización de mis ideas sobre este tema, por lo que es necesariamente general y todavía falto de fundamentación documental, aunque espero que la exposición de conjunto tenga la congruencia suficiente para que parezca al menos como un pensamiento no descabellado.

\section{EL FUNDAMENTO DEL DEBER}

La persona humana tiene conciencia de ser alguien inacabado, alguien que está por hacerse y que está haciéndose. No tiene en vida un momento de reposo pleno en el que pueda decirse a sí misma "ya estoy hecha", sino que siempre está en proceso de ser y dejar de ser.

La misma conciencia da testimonio de que la persona se realiza por medio de sus acciones. Las acciones de la persona, de las que ella es causa eficiente en el sentido no sólo de ser quien las produce, sino también quien las mantiene o suspende, sirven, por una parte, como medios para conseguir fines externos a ella, como son todos los bienes que necesita para su subsistencia y desarrollo; pero las acciones también sirven, por otra parte, como medios para la construcción de la misma persona, puesto que ella misma queda conformada por las acciones que ejecuta. Así, quien estudia derecho no sólo adquiere conocimientos jurídicos, sino que su misma inteligencia se modifica, se conforma al modo de pensar jurídico. Por eso se afirma que las acciones de la persona tienen un fin o signi-

2 D’Ors, Á., Una introducción al estudio del derecho, 3a. ed., Madrid, Rialp, 1977.

3 Pero no todo lo que está en las leyes es derecho, ni todo el derecho está en las leyes. 
Este obra forma parte del acervo de la Biblioteca Jurídica Virtual del Instituto de Investigaciones Jurídicas de la UNAM www.juridicas.unam.mx

ficado transitivo, que es a fin de cuentas el dominio o humanización del mundo, y otro intransitivo, que es la construcción de la propia persona. Aquí interesa considerar principalmente el significado intransitivo o de construcción de la persona.

La persona también queda conformada por cosas que ella no hace sino que simplemente le ocurren o le suceden. Así, los hechos terminales de la vida humana, el nacimiento y la muerte, son sucesos que le acaecen a la persona independientemente de su voluntad. Igualmente, todos los procesos somatovegetativos que se dan en el cuerpo de la persona obedecen a una causalidad independiente de la voluntad humana. Sin embargo, la persona puede influir en estos acontecimientos o sucesos de modo indirecto, colocándose en circunstancias o poniendo medios que sirvan para activarlos o desactivarlos, por ejemplo tomando o dejando de tomar medicamentos para remediar una enfermedad. Asimismo, puede influir en cuanto al resultado que tengan esos sucesos en su propia conformación mediante la decisión de asumirlos personalmente de una manera u otra, por ejemplo, encarando una enfermedad con rebeldía o con resignación, tomándola como un castigo o como una prueba, o simplemente como un accidente, etcétera.

La persona es alguien entonces que se conforma a sí misma mediante sus acciones, y también mediante sus decisiones en torno a lo que le ocurre. El vivir de la persona no es un mero sobrevivir o vegetar ni un mero reaccionar a la realidad circundante, sino que es un hacerse a sí misma transformando el mundo circundante; su vida es biografía o historia de un sujeto, y no mero acontecer. La multitud de acciones que ella realiza y la multitud de cosas que le ocurren en la forma que ella las asume se entretejen para ir configurando el rostro de la persona. Con esta labor está ligada su aspiración natural a la propia felicidad. La persona quiere naturalmente la felicidad, y aquí naturalmente significa que no puede dejar de quererla; pero advierte que esa felicidad a la que aspira, vagamente intuida, no es algo que simplemente recibirá, como recibió la vida o como recibirá la muerte, sino que es algo que ella ha de alcanzar por medio de sus acciones.

Esta labor de la persona de hacerse a sí misma implica naturalmente hacer también la comunidad donde vive, principalmente la familia y la nación, no sólo porque la persona necesita para subsistir del grupo social, en el sentido de que no puede proporcionarse por sí los satisfactores necesarios para mantener su vida al mero nivel de sobrevivencia, sino princi- 
Este obra forma parte del acervo de la Biblioteca Jurídica Virtual del Instituto de Investigaciones Jurídicas de la UNAM www.juridicas.unam.mx

palmente porque se desarrolla a sí misma en sus facultades superiores precisamente estando en comunión con otras personas, actuando con ellas, queriendo lo que ellas quieren, y a veces quizá sólo porque las otras lo quieren, y trabajando conjuntamente por fines o bienes comunes. Esto lo evidencia el mero lenguaje que, siendo el instrumento necesario para el desarrollo afectivo e intelectual de la persona, es un resultado, y al mismo tiempo presupuesto, de la colaboración entre personas.

El hacerse a sí misma y, consecuentemente, a la comunidad, es la tarea fundamental de la persona. Esto supone la estimación de que la persona es un bien en sí mismo de valor superior a las cosas, incluidos en esta categoría los sistemas sociales, la ciencia, la cultura, el derecho o el Estado, los cuales son sólo bienes mediales o útiles al servicio de la persona. No se trata de replantear la inútil polémica entre individualismo y colectivismo, porque precisamente la persona no es individuo aislado, sino — como se afirma desde Kierkegard -4 un yo referido a un tú, de modo que el bien de la persona es igualmente bien de la comunidad, tal como el buen profesional, maestro o padre de familia es un bien para sus colegas y clientes, para sus discípulos, para su esposa e hijos, para su patria.

En esta labor de hacerse a sí misma y a la comunidad, la persona procede, como le es natural, guiada por la inteligencia, de manera semejante a como procede en la labor de construcción y dominio del mundo. Y así como para construir una presa deben observar las relaciones objetivas que se dan entre las cosas, y auxiliarse de la ingeniería hidráulica, de manera semejante debe observar la relación objetiva que se da entre su conducta y el perfeccionamiento de sí y de la comunidad. Esta relación objetiva entre la conducta libre y el perfeccionamiento de la persona es la verdad ética o verdad acerca del bien del hombre.

La referencia natural del actuar de la persona hacia la verdad acerca de su propio perfeccionamiento o verdad sobre el hombre, le hace ver la relación de conveniencia o disconveniencia de sus actos con su perfeccionamiento personal y el de la comunidad. Esta relación, en cuanto es algo objetivo, cognoscible por la sola razón e independiente de la voluntad humana, se manifiesta como una ley u ordenamiento, que constituye el fundamento objetivo de todo deber o prohibición: las conductas que son con-

4 Ver Caso, A., La persona humana y el Estado totalitario, México, UNAM, 1941, pp. 199200. 
Este obra forma parte del acervo de la Biblioteca Jurídica Virtual del Instituto de Investigaciones Jurídicas de la UNAM www.juridicas.unam.mx

venientes a ese fin son las conductas debidas, y las que son inconvenientes al mismo son las prohibidas.

Pero las nociones de deber y prohibición se forman no sólo con el mero reconocimiento de la relación objetiva entre la conducta y el perfeccionamiento, sino que hace falta además la aprobación subjetiva, es decir, que la persona apruebe el juicio que afirma que una conducta es debida o prohibida, y lo apruebe no sólo en su formulación general sino además como algo vinculante para ella aquí y ahora. Por ejemplo, no basta con reconocer la relación objetiva entre estudiar y el perfeccionamiento personal y aprobar el juicio "estudiar es bueno" para que alguien experimente el deber de estudiar, sino que hace falta que lo experimente como algo vinculante para ella aquí y ahora para que pueda decirse a sí misma "yo debo estudiar".

Resulta, así, un fundamento doble de los deberes y prohibiciones: a) uno objetivo, la relación entre la conducta y el perfeccionamiento personal y comunitario, que se expresa por medio de juicios que afirman que ciertas conductas son debidas y otras prohibidas, y b) otro subjetivo, consistente en la aprobación personal, en conciencia, de tales juicios.

En pocas palabras, puede decirse que el fundamento del deber es lo objetivamente conveniente a la persona y a la comunidad y aprobado por ella como tal. Este es el fundamento de todos los deberes, tanto de los deberes éticos como de los deberes políticos y de los jurídicos.

Precisado este fundamento común, pasaré a proponer una explicación de los contenidos y características distintivas de los deberes contemplados respectivamente por la ética, la legislación y el derecho.

\section{LOS DEBERES ÉTICOS}

La ética es la ciencia que elabora y sistematiza los juicios (también llamados reglas o normas) respecto de la conducta humana libre en orden al perfeccionamiento personal y comunitario. El juicio ético es el que afirma o niega que una conducta es debida o prohibida. La veracidad del juicio ético depende de que las conductas que se afirman como debidas o prohibidas sean realmente convenientes o disconvenientes a la persona y a la comunidad. La ética, en la formulación de sus juicios, como cualquier otra ciencia, puede acertar o equivocarse; pero tiene, lo mismo que las demás ciencias, la aspiración fundamental de acertar, sin la cual sería imposible cualquier trabajo científico. 
Este obra forma parte del acervo de la Biblioteca Jurídica Virtual del Instituto de Investigaciones Jurídicas de la UNAM www.juridicas.unam.mx

La ética parte de una verdad axiomática que dice "obra el bien y evita el mal", obra aquello que te perfecciona y evita lo que te degrada. Es un principio evidente y que corresponde perfectamente a la inclinación natural del hombre a su propia felicidad, por lo que podría también formularse diciendo "obra aquello que te hará feliz y evita lo que te hará infeliz", ya que la felicidad, como estado subjetivo de la persona, se identifica con la posesión objetiva del bien, es decir, con el perfeccionamiento de la persona.

Este primer principio hace una discriminación necesaria entre las conductas humanas: hay unas que perfeccionan y otras que perjudican a la persona y a la comunidad. A partir de esta discriminación inicial, la razón humana puede juzgar de cada conducta si corresponde a una categoría u otra y, como consecuencia, señalar si son conductas debidas o deberes o si son conductas prohibidas o prohibiciones. La ética es, pues, la ciencia que formula los deberes y prohibiciones que la persona ha de observar en orden a su perfeccionamiento. En general, y sin entrar en detalles, se aceptan comúnmente tres deberes y cuatro prohibiciones fundamentales.

Los deberes fundamentales son: el deber de la persona de amarse a sí misma, el de amar al prójimo y el de amar a Dios como el Creador y Dador del ser y la vida. Los tres están firmemente arraigados en la naturaleza humana, aunque los dos primeros se apoyan también en instintos biológicos, el de conservación y reproducción, y el último, en la aspiración natural del espíritu humano a la verdad, el bien y la belleza.

El deber de amor a uno mismo se corresponde con el instinto de conservación, pero no se identifica con él. Sólo se concibe cuando la inteligencia percibe el valor o dignidad de la persona, como un bien que merece amarse por sí mismo, es decir, como un bien honesto. La noción del deber no es un resultado del instinto, sino que se apoya en la existencia del instinto, pero depende principalmente del juicio de la razón acerca del valor eminente de la persona y de su destino trascendente.

El amor del prójimo es un deber que se apoya parcialmente en el instinto de reproducción, pero depende del reconocimiento del prójimo como una persona, como alguien que, al igual que uno mismo, merece ser amado por lo que es y no como medio o bien útil. Por eso, la medida de este amor al prójimo es el amor de sí mismo: ama a tu prójimo como a ti mismo; no más, porque sería darle una categoría que no tiene; ni menos, porque sería menospreciarlo. 
Este obra forma parte del acervo de la Biblioteca Jurídica Virtual del Instituto de Investigaciones Jurídicas de la UNAM www.juridicas.unam.mx

El deber de amar a Dios tiene un doble sustento racional. Se funda, por una parte, en el reconocimiento de Él como creador, dador y sustentador de la vida humana. Es entonces, por principio de cuentas, un deber de gratitud. Pero tiene también como fundamento el reconocimiento de Dios como la Verdad, el Bien y la Belleza absolutas, en quien está la felicidad a la que naturalmente aspiramos; es decir, el reconocimiento de que el amor de Dios, tanto en el sentido de amor de la persona a Dios como en el de amor de Dios a la persona, es la razón más profunda y el último fin de la vida humana.

Estos tres deberes se pueden enunciar así en sentido general, pero su cumplimiento se concreta en multitud de actos en los que práctica y efectivamente la persona se ama a sí, a su prójimo y a Dios, que van desde el cuidado de la salud, el cultivo de la inteligencia, hasta los actos de culto y de confianza en Dios, pasando por los actos de amistad, de justicia y compasión con el prójimo. Son deberes, pues, que marcan caminos anchos por donde cada persona ha de transitar con entera libertad y escogiendo en cada momento lo que resulte más adecuado y mejor.

Las prohibiciones tienen un significado más restringido, pero también más preciso. Señalan las conductas que de ser realizadas, o incluso de ser meramente queridas por la voluntad, degradan a la persona al ponerla en directa contradicción con su naturaleza racional. Son la prohibición del homicidio, del robo, del adulterio y de la mentira. Estas prohibiciones son conceptos límite o frontera, en el sentido de que marcan las conductas que rebasan los límites de lo humano. No obstante su fomulación negativa, implican un contenido positivo en tanto que son como barreras que defienden de manera precisa e indeclinable la vida humana, la propiedad privada, el amor humano, la veracidad y la buena fama.

Los deberes éticos (incluyendo en ellos las prohibiciones como deberes negativos o de no hacer) si bien obligan "en conciencia", es decir, que la persona los experimenta como urgencia íntima de hacer o no hacer algo, pueden sin embargo ser exigidos por las personas o por la comunidad a quienes afecta su incumplimiento. Los deberes éticos pueden distinguirse de otros deberes por el modo como se exige su cumplimiento: por vía de reproche o amonestación, lo que incluye desde la amonestación paterna hasta el rechazo social, así como diversas formas de advertencia, como la que se hace entre amigos, la que se hace entre cónyuges o la que pueden hacer los policías o los gobernantes. Siendo socialmente exigibles, los deberes éticos se integran en la vida social como parte —en mi 
Este obra forma parte del acervo de la Biblioteca Jurídica Virtual del Instituto de Investigaciones Jurídicas de la UNAM www.juridicas.unam.mx

opinión la parte fundamental—, del orden social. Se definen y propagan principalmente por medio de las tradiciones familiares. ${ }^{5}$

\section{LOS DEBERES POLÍTICOS}

De los deberes éticos, cabe distinguir aquellos cuyo cumplimiento importa principalmente a la persona individual, de aquellos cuyo cumplimiento interesa a la comunidad. Por eso, suele hablarse de una ética individual y una ética social.

Los deberes ético-sociales son básicamente los comprendidos en el deber general de amor al prójimo; los principales son el deber de colaboración en la consecución del bien comunitario o deber de solidaridad y el deber de dar a cada quien lo suyo o deber de justicia. Los diferentes grupos humanos tienden a asegurar el cumplimiento de estos deberes por medio de leyes. Hablo aquí de leyes en sentido lato, de modo que se incluyen los reglamentos, decretos y demás disposiciones administrativas, e incluso las leyes particulares o estatutos de grupos intermedios.

Estos deberes definidos en las leyes pueden denominarse en general "deberes comunitarios", puesto que todos se refieren a conductas necesarias o muy convenientes para el bien de la comunidad. Son una multitud de deberes de contenido diverso que comprenden, por ejemplo, el deber de pagar una cuota de mantenimiento de un club deportivo, el de respetar los estatutos de una asociación civil o el reglamento de higiene de una empresa, así como el de votar en las elecciones de gobernantes, pagar los impuestos o desempeñar los cargos públicos de conformidad con las leyes, y también todos los deberes prescritos en los reglamentos de policía, las leyes mercantiles y demás ordenamientos.

De entre estos deberes comunitarios pueden distinguirse los deberes políticos, como aquellos que se refieren específicamente al bien de la comunidad política o república, y que son los que están definidos en las leyes (de cualquier tipo) promulgadas y sancionadas por el poder público. Se distinguen del resto de los deberes comunitarios por dos causas: por razón del fin, que es el bien de la república, y por razón del instrumento que los sanciona, que es un ordenamiento promulgado y sancionado por el poder público.

5 No debe pasarse por alto el papel de la Iglesia y las demás asociaciones religiosas en la difusión de una ética ligada al credo religioso, pero esa labor llega finalmente a las familias y en ellas produce frutos. 
Este obra forma parte del acervo de la Biblioteca Jurídica Virtual del Instituto de Investigaciones Jurídicas de la UNAM www.juridicas.unam.mx

https://biblio.juridicas.unam.mx/bjv

El cumplimiento de estos deberes políticos está asegurado mediante una sanción pública. Debe notarse que se trata en su origen de deberes éticos, de modo que la razón de que sean debidos es la misma de todos los deberes: el que sean conductas adecuadas al bien de la persona y de la comunidad. El ordenamiento legislativo que los recoge y promulga lo único que hace es aprobarlos como deberes, sustituyendo en esto de algún modo la aprobación de la conciencia personal con el consenso comunitario, ${ }^{6}$ y añadir una sanción para asegurar su cumplimiento. Podría pensarse que puede haber deberes definidos en las leyes que no puedan ser formulados como conclusiones derivadas de los principios éticos fundamentales, como la que establecen los reglamentos de tránsito de que los automovilistas conduzcan por el lado derecho de las calles, pero el fundamento de este deber, como el de cualquier otro sancionado legalmente, es el deber ético (derivado del deber de solidaridad) de obedecer las leyes promulgadas por la potestad pública legítimamente constituida.

En la mayoría de las leyes se prevén castigos para el caso de que sean incumplidas, que en el lenguaje legal se denominan sanciones administrativas, es decir, sanciones que imponen los órganos gubernamentales correspondientes y que son de muy variados tipos: multas, negativas o revocaciones de permisos o concesiones, cobro de gastos administrativos, impuestos compensatorios, clausuras, decomisos, arrestos, etcétera. Para la imposición de las sanciones de este tipo, el órgano gubernamental debe cumplir un determinado procedimiento, y el afectado puede ordinariamente pedir una revisión de la decisión ante una instancia superior del órgano administrativo que la tomó.

El conjunto de leyes se integra también en el orden social configurando un orden legislativo u orden de leyes. Este orden constituye y regula la cosa pública o república. Pero no es todo el orden social, sino parte de él, de la misma manera que la república no se identifica con la sociedad (o nación), sino que es un aspecto, ciertamente determinante, pero no más que un aspecto, de la sociedad.

6 No se quiere decir que la aprobación comunitaria o promulgación sustituya completamente la conciencia personal, puesto que a ésta siempre le corresponde el último juicio sobre si la conducta definida en la ley es finalmente debida o no; pero ciertamente la promulgación de una ley es un hecho que ha de mover a la conciencia personal a tener como debidas las conductas prescritas en ellas, en tanto que los gobernantes las han juzgado como convenientes al bien común. 
Este obra forma parte del acervo de la Biblioteca Jurídica Virtual del Instituto de Investigaciones Jurídicas de la UNAM www.juridicas.unam.mx

\section{LOS DEBERES JURÍDICOS}

De los deberes de justicia y solidaridad reconocidos por las leyes, hay algunos cuyo cumplimiento resulta, por así decirlo, más necesario para la subsistencia del orden social, por lo que los grupos sociales buscan asegurar su cumplimiento no sólo mediante las leyes, sino además estableciendo la posibilidad de que las personas afectadas, no necesariamente los órganos gubernamentales, puedan exigir su cumplimiento ante órganos jurisdiccionales independientes del gobierno, es decir, ante los jueces estos deberes cuyo cumplimiento puede ser judicialmente exigible son los que puede denominarse deberes jurídicos.

Se trata, como los deberes comunitarios, de deberes que son originalmente deberes éticos de justicia y solidaridad, pero que se sancionan socialmente a través de órganos jurisdiccionales o jueces independientes (más o menos según el lugar y el tiempo) del poder gubernamental, quienes pueden imponer al transgresor una pena y forzarlo al cumplimiento del deber o a una reparación del daño causado con el incumplimiento.

La necesidad de una sanción diferente, de la coacción judicial en vez de la pena administrativa, deriva de la mayor importancia que tiene para la sociedad el cumplimiento de estos deberes. Originariamente la coacción judicial, y con ella el derecho, aparece para la represión de conductas que violan las prohibiciones fundamentales, es decir, para el castigo y reparación del robo, el homicidio, el adulterio y la mentira. Por eso, puede afirmarse que el derecho se fundamenta en esas prohibiciones o preceptos negativos: el derecho penal castiga precisamente la violación de estas prohibiciones; el derecho familiar se estructura sobre la base de la fidelidad conyugal y el castigo del adulterio; el derecho privado se estructura a partir del castigo del robo y del respeto a la propiedad, y a partir del castigo de la mentira y de la consecuente fidelidad a la palabra o fides, que es el punto de partida de los contratos.

La definición de lo jurídico en cada momento y sociedad depende de lo que cada comunidad juzgue como de mayor importancia. Hay conductas que ordinariamente tienen una coacción judicial más o menos diferenciada, en todos los pueblos y en diferentes épocas, como son las que constituyen violaciones directas de las prohibiciones fundamentales. Pero hay muchos deberes que se sancionan jurídicamente en ciertas épocas y pueblos y en otros no. Por ejemplo, las conductas relacionadas con la protección ambiental: el cuidado del medio ambiente y de los bienes en ge- 
Este obra forma parte del acervo de la Biblioteca Jurídica Virtual del Instituto de Investigaciones Jurídicas de la UNAM www.juridicas.unam.mx

https://biblio.juridicas.unam.mx/bjv

neral es un deber ético, que ahora se ha sancionado mediante leyes de protección ambiental, convirtiéndolo así en un deber político cuyo incumplimiento sanciona el gobierno, y que además se ha transformado en un deber jurídicamente exigible mediante el otorgamiento a los ciudadanos de acciones populares ejercitables ante órganos jurisdiccionales (o cuasijurisdiccionales).

Como lo decisivo para considerar un deber como jurídico es la posibilidad de reclamación judicial, la ciencia del derecho se organiza no tanto como estudio sistemático de los deberes, sino más bien como orden sistemático de las acciones o derechos a exigir judicialmente el cumplimiento de deberes. Por eso, me parece que no es conveniente hablar de "deberes jurídicos", sino que es más preciso hablar de deberes jurídicamente o judicialmente exigibles.

Los derechos pueden estar definidos en las leyes o en otros instrumentos como sentencias de los jueces, costumbres u opiniones de autores reconocidos por los jueces como autoridades en el discernimiento de lo justo en el caso concreto.

El conjunto de derechos se integra también en el orden social como orden jurídico. Pero hay una diferencia importante respecto del orden legislado. El orden legislativo tiene fundamentalmente una función integradora: la de definir y sancionar conductas necesarias y convenientes para el bien de la república. En cambio, el orden jurídico tiene más bien una función reparadora: la de restablecer el orden social violado, y por eso se presenta como orden de derechos, de exigencias, y no como orden de deberes.

Un punto interesante de conexión entre el orden de leyes y el orden jurídico se da en aquellas leyes que establecen el control judicial de los actos de gobierno, como por ejemplo, las leyes fiscales. El deber de los ciudadanos de pagar impuestos es un deber político, cuyo incumplimiento lo sanciona directamente la administración fiscal; pero la sanción impuesta puede ser revisada por un órgano judicial independiente, por lo que el deber de la instancia fiscal de respetar las leyes es un deber jurídico cuyo incumplimiento pueden reclamar judicialmente los causantes. Resulta así que las leyes fiscales definen tanto el deber de los ciudadanos de pagar impuesto, como el derecho de los mismos de exigir que las instancias fiscales respeten la legalidad establecida. Cuando se habla ahora de "Estado de derecho", en mi opinión eso debe entenderse en el sentido de gobierno sujeto a control judicial, y no en el sentido de gobierno o Estado 
Este obra forma parte del acervo de la Biblioteca Jurídica Virtual del Instituto de Investigaciones Jurídicas de la UNAM www.juridicas.unam.mx

organizado por medio de leyes, lo cual debiera denotarse mejor con la expresión "Estado de legalidad".

\section{PROPOSICIONES}

Con objeto de hacer más expreso mi pensamiento sobre el tema analizado, lo sintetizo aquí en tres proposiciones que dejo a la consideración del lector:

la. El fundamento, causa o razón del deber ético, político o jurídico es siempre el mismo: la relación de conveniencia o disconveniencia de una conducta personal con el bien de la persona y la comunidad.

2a. La diferencia más palpable entre deberes éticos, políticos y jurídicos es el modo en que se difunden y se exige su cumplimiento: los deberes éticos se conservan, tutelan y difunden por las familias y las tradiciones familiares, y se exigen por vía de reproche o amonestación. Los deberes políticos se difunden por medio de las leyes, y su cumplimiento lo exige el poder público (el Poder Ejecutivo, según la terminología constitucional actual). Los deberes jurídicos son definidos principalmente por los juristas, cuyas conclusiones son asumidas por las tradiciones judiciales y las leyes, y son exigidos por los jueces.

3a. El orden social es fundamentalmente un orden ético, un orden de deberes, reforzado, en cierto sector, como orden de leyes y como orden de juicios. Para una vida social sana es necesario un orden con estos tres sectores debidamente integrados y equilibrados. No es un progreso convertir todos los deberes en deberes jurídicamente exigibles, o legalmente sancionables. En este sentido, la aspiración de ser, como se dice ahora, "un país de leyes", es una aspiración incompleta y errónea, ya que sería inhumano, además de prácticamente imposible, sancionar todos los deberes personales y comunitarios con el apoyo del poder público. El ideal completo sería ser "un país de tradiciones éticas, de leyes y de jueces". 


\section{UNA NUEVA PROPUESTA IUSNATURALISTA EN LA FILOSOFÍA MEXICANA PARA FUNDAMENTAR LOS DERECHOS HUMANOS}

\section{Enrique I. AGUAYO CRUZ}

SUMARIO: I. Introducción. II. Definición de filosofía del derecho. III. Concepto de iusnaturalismo. IV. Fundamento del derecho y de los deberes. V. Fundamento del derecho natural o derechos humanos. VI. Necesidad de fundamentar el derecho natural. VII. Relación entre derecho natural y felicidad. VIII. Relación entre derecho natural y derecho positivo. IX. Conclusión.

\section{INTRODUCCIÓN}

Es común en nuestros días que la gente, tanto en los medios de comunicación masiva como en las charlas cotidianas, se ocupe de los derechos humanos, en virtud de que son violados a cada instante, de diversos modos, por personas que tienen diferentes tipos de autoridad: un policía, un juez, un padre de familia, un profesor, un ejecutivo, etcétera.

Es claro, al menos para nosotros, que tales violaciones están, en la mayoría de los casos, provocadas por distintos intereses: económicos, políticos, ideológicos, religiosos, educativos, etcétera. Hay ocasiones, quizás las menos, en que se infringen los derechos humanos por ignorancia, porque se desconocen o no se comprenden con cierto detalle.

De ahí la importancia de volver una y otra vez sobre el tema de los derechos humanos (o naturales) para promoverlos y defenderlos, evitando, en la medida de lo posible, que se quebranten. Veremos aquí los planteamientos del filósofo mexicano Mauricio Beuchot sobre la posibilidad de una fundamentación filosófica iusnaturalista para estos derechos.

Para este autor hogaño se llaman derechos humanos los mismos derechos que antaño equivalían, al menos en parte, al derecho natural. El concepto que él prefiere es el segundo, porque —así lo creemos- está en 
Este obra forma parte del acervo de la Biblioteca Jurídica Virtual del Instituto de Investigaciones Jurídicas de la UNAM www.juridicas.unam.mx

función de comprender que el hombre, cada ser humano, por el hecho de serlo, tiene derechos, los mismos, y sin excepción, para todos.

Siguiendo su iusnaturalismo, nosotros también aceptamos el concepto de derecho natural, además de la razón ya expuesta, porque el hombre, para poder existir, debe estar dotado con un mínimo de elementos que le permitan su supervivencia. Más aún: la naturaleza dota a todos los seres de los elementos necesarios que le permitan existir del mejor modo. Y la persona no es la excepción. Pero a diferencia del resto de los seres del mundo, el hombre busca y desea la felicidad. Por tanto, el respeto al derecho natural le proporcionará su felicidad, la cual le dará una razón para vivir.

Algunos de esos elementos con los que estamos dotados para poder ser felices son los derechos naturales: a la vida, la libertad, la amistad; al alimento, al vestido, al hogar, al juego; a la educación, al estudio, al trabajo; a la formación de la propia familia, la asociación de personas; la expresión; a profesar alguna religión e ideología, etcétera. Todo ello dentro de lo bueno, lo lícito y lo justo.

A nuestro juicio, el objetivo primordial de Beuchot, al tratar el tema del derecho natural, consiste en fundamentarlo filosóficamente en el mismo ser del hombre, lo cual significa que el derecho natural es anterior al derecho positivo. En consecuencia, éste no puede ser el fundamento del derecho natural o derechos humanos, y menos aún lo serán los acuerdos entre los hombres o el capricho de algún legislador o gobernante.

El estudio de Beuchot encuéntrase inscrito dentro del tomismo, pero lo desborda, pues no sólo reflexiona sobre aspectos tomistas, sino que también sigue a autores ajenos a esa corriente.

Estudia a Santo Tomás, a los tomistas de la escuela de Salamanca del siglo XVI; los frailes dominicos como Francisco de Vitoria, Bartolomé de las Casas y Domingo de Soto; los actuales tomistas, como J. Finnis, Carlos I. Massini, Héctor H. Hernández, J. García-Huidobro, etcétera, y, desde luego, desarrolla su propio pensamiento.

De autores ajenos al tomismo, encontramos al franciscano Guillermo de Ockham y al jesuita Francisco Suárez, de los que acepta el concepto de derecho subjetivo y lo rastrea, en cuanto a contenido, no en cuanto a la expresión, en la obra de Santo Tomás, para unirlo al concepto de derecho objetivo, con el fin de tener completa la noción de derecho natural o derechos humanos.

También entra en debate con algunos autores que cuestionan la vigencia y alcance del derecho natural, como Norberto Bobbio, y otros que 
Este obra forma parte del acervo de la Biblioteca Jurídica Virtual del Instituto de Investigaciones Jurídicas de la UNAM www.juridicas.unam.mx

https://biblio.juridicas.unam.mx/bjv

lo conciben de diversa manera, como Leo Strauss. Igualmente, considera otras interpretaciones del derecho natural tomista, e intenta responder a ellas. Para ello utiliza instrumentos metodológicos tomados de la filosofía analítica, con autores tales como R. Dworkin, D. Wiggins, C. S. Nino y P. Dieterlen.

El estudio de la filosofía del derecho supone, necesariamente, una visión ontológica de la persona, tema este que hemos expuesto en otra parte. ${ }^{1}$ Por ello, para tratar ahora la concepción beuchotiana de filosofía del derecho, hemos estructurado este artículo en siete incisos: I. Introducción; II. Definición de filosofía del derecho; III. Concepto de iusnaturalismo; IV. Fundamento del derecho y de los deberes; V. Fundamento del derecho natural o derechos humanos; VI. Necesidad de fundamentar el derecho natural; VII. Relación entre derecho natural y felicidad, y VII. Relación entre derecho natural y derecho positivo. Añadimos una breve conclusión.

\section{DEFINICIÓN DE FILOSOFÍA DEL DERECHO}

"Es el estudio de la ley para ver su conexión con la ética, a través del derecho natural, que rige al derecho positivo". ${ }^{2}$ Veamos. Primero, Beuchot ubica la filosofía del derecho como ampliación de la ética, por lo cual entre ésta y la ley hay un vínculo, que consiste en lo siguiente: para que un acto humano y el objeto hacia el que se dirige sean buenos, deben estar adecuados a una norma de moralidad, la cual, en el tomismo, es doble: la ley y la conciencia. La ley es norma remota de moralidad, y la conciencia es norma próxima. Según Santo Tomás, al decir de Beuchot, "la ley es una orientación objetiva encontrada por la inteligencia y la razón", a la que debe seguir el hombre para poseer su fin propio, ${ }^{3}$ que es doble: a) objetivo, consistente en la propia perfección, y b) subjetivo, que es la felicidad a la que todo ser humano aspira. La ley la considera nuestro autor en su doble aspecto: a) natural, en sentido moral, y b) en su dimensión positiva, o sea, las leyes creadas por el hombre. Segundo, por el derecho natural el hombre hace el bien y evita el mal, como le ordena su

1 Aguayo Cruz, E. I., "El concepto de persona en la filosofía de Mauricio Beuchot", Estudios, México, ITAM, núm. 41, 1995, pp. 85-94.

2 Cfr. Beuchot, M., "Sobre el concepto de filosofía”, Logos, México, ULSA, núm. 71, 1996, p. 74.

3 Cfr. el mismo, Introducción a la filosofía de Santo Tomás de Aquino, México, UNAM, 1992, p. 135. Téngase presente la distinción que establece Santo Tomás entre actos del hombre y actos humanos. 
Este obra forma parte del acervo de la Biblioteca Jurídica Virtual del Instituto de Investigaciones Jurídicas de la UNAM www.juridicas.unam.mx

sindéresis o hábito de los primeros principios prácticos. Ese derecho se concretiza en los bienes que alguien necesita para existir dignamente: derecho a la vida, al alimento, a la educación, etcétera. Tercero, según Beuchot, el derecho natural rige al derecho positivo, pues éste - creemos nosotros- debe custodiar el ser, el hacer y los bienes que pueda obtener cada quien; es decir, el derecho positivo debe salvaguardar los derechos naturales del hombre. Si el derecho positivo viola el derecho natural, entonces es injusto.

\section{CONCEPTO DE IUSNATURALISMO}

El vocablo "iusnaturalismo" está compuesto por dos términos y un sufijo latinos: ius, iuris, que se traduce por derecho; naturalis, -e, que quiere decir natural (remite a la naturaleza), y el sufijo -ismo, que significa doctrina o ideología.

Antes de exponer y explicar el concepto de iusnaturalismo, veamos cómo define Beuchot las voces "derecho" y "naturaleza".

\section{Concepto de derecho}

En nuestra opinión, Beuchot toma la palabra "derecho" en su acepción ética, pero en dos sentidos distintos. En primer lugar, entiende el derecho como "la potestad de hacer u omitir algo". ${ }^{4}$ Esta definición no es en sentido jurídico. En consecuencia, no se está tomando en su aspecto bilateral y externo. ${ }^{5}$ Simplemente se trata de la posibilidad que cada quien tiene para hacer $u$ omitir algo, sobre todo cuando se trata de perfeccionarse a sí mismo mediante la posesión de ciertos bienes que se requieren. Por eso dice que la persona tiene dominio de sus actos, goza de la potestad - física y moral- de hacer u omitir ciertas cosas. Sobre todo en aquellas cosas que le son necesarias para realizar su propia naturaleza. ${ }^{6}$

En este sentido, el derecho natural — dice él- puede denominarse también "derecho subjetivo natural". ${ }^{7}$ Así, el derecho natural o derecho subjetivo natural es una capacidad o una libertad que posee la persona p. 23.

4 Cfr. el mismo, Derechos humanos, iuspositivismo y iusnaturalismo, México, UNAM, 1995,

5 Para una definición jurídica de derecho puede verse, v. gr., E. García Máynez, Diálogos jurídicos, México, Porrúa, 1978, p. 189.

6 Beuchot, M., Derechos humanos..., pp. 23-24.

7 Cfr. ibidem, pp. 7, 47, 63 y 98. 
Este obra forma parte del acervo de la Biblioteca Jurídica Virtual del Instituto de Investigaciones Jurídicas de la UNAM www.juridicas.unam.mx

https://biblio.juridicas.unam.mx/bjv

para hacer o no hacer algo. ${ }^{8}$ Afirma nuestro autor que, en la actualidad, el derecho natural o derecho subjetivo natural es lo que comúnmente se llama derechos humanos. ${ }^{9}$

El segundo sentido del término "derecho" es recibir algo, como cuando se dice que alguien tiene derecho a... obtener ciertos satisfactores para sobrevivir dignamente. Este significado aparece más abajo, en el inciso 4 a).

Ahora bien, hasta el momento hemos hablado de derecho natural, derechos subjetivos naturales y derechos humanos. En la ciencia jurídica la palabra "derecho" tiene diversas acepciones, tales como derecho objetivo, derecho subjetivo, derecho vigente y derecho natural. ${ }^{10}$ ¿Esto significa que la palabra "derecho" es equívoca? Beuchot considera que no, que más bien es analógica, pues el contenido del vocablo no cambia, lo que varía es su aplicación. En efecto, él afirma que el sentido más propio de "derecho" es el positivo, porque tiene fuerza coercitiva; pero, aun cuando sea en un sentido menos propio, el derecho natural puede llamarse "derecho", porque su fuerza radica en la obligación moral, en la fuerza de la conciencia y no sólo en los buenos deseos. ${ }^{11}$

De modo que, para que algo pueda ser llamado "derecho", tiene que ser coercitivo, pues su cumplimiento consiste en que una persona debe adecuar su conducta a las leyes jurídicas, excluyendo, pero no negando, aspectos internos del sujeto, como la intención o el respeto al deber moral. Por eso el derecho obliga.

Beuchot piensa que el aspecto propio del derecho es el objetivo. Lo define como "una característica que posee la cosa, la persona o la relación justa" ${ }^{12}$ es decir, como algo que es correcto y justo. Derivado de este aspecto objetivo, se da el de derecho subjetivo, en tanto propio del individuo o sujeto.

Así pues, para que el concepto de derecho sea analógico, siempre que se lo considere y aplique debe incluir el elemento coercitivo, en sus dos aspectos: externo, aplicado por alguna autoridad competente a quien no

8 Ibidem, p. 29. En esta parte, Beuchot expone el concepto de derecho subjetivo de Guillermo de Ockham.

9 Ibidem, p. 7.

40 .

10 Cfr. García Máynez, E., Introducción al estudio del derecho, México, Porrúa, 1986, pp. 36-

11 Cfr. Beuchot, M., op. cit., p. 124.

12 Ibidem, pp. 63 y 98. 
Este obra forma parte del acervo de la Biblioteca Jurídica Virtual del Instituto de Investigaciones Jurídicas de la UNAM www.juridicas.unam.mx

obedezca las leyes positivas, e interno, proveniente de la conciencia recta de cada quien.

\section{Concepto de naturaleza}

La palabra "naturaleza" está restringida aquí al hombre, y Beuchot la refiere a la razón humana, que es lo que de más natural tiene la persona, ${ }^{13}$ porque justamente la razón es la que diferencia al hombre del resto de los vivientes en el orden de lo finito intramundano.

Para evitar confusiones, es importante aclarar que nuestro autor no toma el vocablo "naturaleza" en el sentido de Hobbes, Locke o Rousseau, quienes dicen que el hombre, antes de formar una sociedad, se hallaba en estado de naturaleza, solo y siendo cada quien libre de llevar a cabo sus acciones sin tomar en cuenta a nadie; y siendo, además, cada individuo, señor único de sus bienes y juez exclusivo de sus propias actividades. La sociedad, según los tres autores, surge por convención o acuerdo entre los seres humanos.

Por el contrario, para Beuchot, siguiendo a Santo Tomás, lo natural en el hombre es estar en sociedad. Así que el estado de naturaleza humano es el vivir en sociedad, la cual, como se vio antes, es formada porque el hombre es racional. Sin embargo, también tiene un aspecto convencional, en cuanto al modo de realizarse.

Volvamos al concepto de naturaleza. Para nuestro autor, "la naturaleza misma es un hecho que ya está cargado de valor [porque] tiene implicaciones morales y jurídicas". ${ }^{14}$ Los valores —según él— “muestran lo que es relevante para nosotros", 15 de suerte que la naturaleza humana o racionalidad es valiosa en sí y portadora de valores, pues es la que más estima el ser humano, ya que por ella es como actúa. Esto puede constatarse fácilmente. Cuando alguien, por ejemplo, comete un error, suele decir: “¿por qué no lo pensé primero?”, “¿por qué no se me ocurrió antes?", etcétera, o, para evitar los errores, siempre se aconseja "pensar antes de actuar". 
Este obra forma parte del acervo de la Biblioteca Jurídica Virtual del Instituto de Investigaciones Jurídicas de la UNAM www.juridicas.unam.mx

https://biblio.juridicas.unam.mx/bjv

\section{Definición de iusnaturalismo}

Aceptando la filosofía tomista, Beuchot define el iusnaturalismo o derecho natural como un conjunto de principios y normas de tipo más bien ético o moral; esto es, no como una ley en sentido coercitivo, sino en sentido moral o directivo de la conciencia. ${ }^{16}$

Del hecho de que el iusnaturalismo sea un conjunto de principios o normas éticas, se sigue que no es coercitivo. En efecto, desde el punto de vista moral, no hay modo externo de obligar a alguien a cumplir normas éticas. La única sanción posible es interna: dimana de la conciencia, y consiste en el remordimiento. ${ }^{17}$ Para que éste se dé, dicho sea de paso, la conciencia debe ser recta, pero si está desviada, entonces, una de dos: o todo se ve como malo (conciencia escrupulosa); o todo se considera como bueno (conciencia laxa). En el primer caso, el remordimiento es patológico: constantemente se da. En consecuencia no hay modo de diferenciar lo bueno de lo malo. En el caso de la conciencia laxa, no hay remordimiento; por tanto no hay castigo interno, de donde se deriva que no existe la posibilidad de distinguir lo bueno de lo malo.

La ley a que se refiere la definición de iusnaturalismo antes citada es la denominada natural: ley natural en sentido moral, por la cual, una vez descubierta, la persona "hace el bien y evita el mal". Esta ley dirige, en efecto, la conciencia, indicándole que debe descubrir y diferenciar tanto el bien como el mal, para llevar a cabo el primero y no realizar el segundo. Proponemos este ejemplo para ilustrar la ley natural:

- Hay que hacer el bien y evitar el mal

- robar es malo o respetar los bienes ajenos es bueno

- luego, no hay que robar o hay que respetar los bienes de los otros.

Nuestro autor afirma que la validez del iusnaturalismo es "independiente y previa a su positivación por parte del legislador”. ${ }^{18}$ Así, primero existe el derecho natural y después, y para custodiarlo, aparece el derecho positivo.

Es importante aclarar que el derecho natural obliga en un sentido, pero en otro no.

16 Ibidem, p. 10.

17 El remordimiento es un fenómeno psicológico, i. e. es característica de la persona sentir dolor por no haber respetado algún precepto que tiene por justo, sea moral, social, religioso, etcétera.

$18 C f$ r. Beuchot, M., op. cit., p. 63. De otra manera hállase en p. 133. 
Es coercitivo si lo consideramos desde la moral, pues será su conciencia la que obligue a cada individuo a cumplir ese derecho. En efecto, la función de la conciencia moral es dirigir los actos humanos (libres y voluntarios) hacia el bien. Por ende, la obligatoriedad es interna. El premio o el castigo que de ahí se siguen es, en el primer caso, doble: la satisfacción de haber actuado rectamente; y la paz interna. En cuanto al castigo, la persona que no obedece los dictados de su propia conciencia experimenta el remordimiento, el cual surge por haber violado alguna norma ética.

El derecho natural no es coercitivo en el sentido de que no hay alguien que obligue a un ser humano a actuar de un modo u otro, no hay forma de obligar a alguien extrínsecamente (como sucede con el derecho positivo), a respetar o violar los preceptos éticos.

Cuando el derecho natural se incardina en el ámbito de lo jurídico, entonces se vuelve coercitivo; ${ }^{19}$ antes de esa incardinación no hay modo de obligar a alguien a respetarlo.

\section{FUNDAMENTO DEL DERECHO Y DE LOS DEBERES}

El fundamento del derecho - al decir de Beuchot- es la persona, pues tiene conocimiento y responsabilidad, actos, éstos, que dimanan de su ser sustancial de naturaleza racional y volitiva. Si la persona tiene conocimiento y libertad, entonces tiene la potestad, física y moral, de hacer $\mathrm{u}$ omitir ciertas cosas. Y esa potestad de hacer u omitir algo es lo que nuestro filósofo ha nombrado "derecho". Dicho fundamento es, en realidad, la naturaleza humana, asiento de las necesidades del hombre y de su alta dignidad.

Por lo que respecta a sus deberes, al ser la persona sociable, "tiene cierta dependencia social", de la cual dimanan sus deberes, "que son obligaciones en un ser dependiente que conoce y reconoce su dependencia" ${ }^{20}$

\section{FUNDAMENTO DEL DERECHO NATURAL O DERECHOS HUMANOS}

El fundamento de los derechos humanos — según nuestro autor- es la misma naturaleza humana considerada desde dos perspectivas diferentes: a) la dignidad, y b) la ley en sentido moral. 
Este obra forma parte del acervo de la Biblioteca Jurídica Virtual del Instituto de Investigaciones Jurídicas de la UNAM www.juridicas.unam.mx

https://biblio.juridicas.unam.mx/bjv

\section{La dignidad de la persona como fundamento del derecho natural}

Beuchot dice que la dignidad de la persona le da "el derecho fundamental de realizar su finalidad, su destino. Es el derecho de alcanzar su propia esencia". ${ }^{21}$ Alcanzar su propia esencia significa que el hombre tiene derecho a perfeccionar su propio ser en los órdenes que lo constituyen: intelectual: estudiar, reflexionar, observar, analizar; volitivo: elegir el bien que sea mejor para él, y corporal: desarrollar habilidades manuales, psicomotrices, etcétera. Ahora bien, como nadie puede perfeccionarse, desde que se está gestando en el vientre materno, a sí mismo, tiene derecho a que otras personas (sus padres, tutores) le vayan dando bienes que lo irán perfeccionando paulatinamente: derecho, en primer lugar, a que viva, se alimente, se vista, se eduque, juegue...; hasta que llegue a la edad en que pueda valerse por sí mismo. Llegada a esa edad, la persona sigue teniendo derechos que le permiten, ahora, vivir por sí misma, dignamente: derecho a formar una familia, a un trabajo honesto y bien remunerado, a formar asociaciones lícitas, etcétera.

Cuando Beuchot afirma que la persona tiene derecho a realizar su destino, quiere decir que el ser humano tiene derecho a trazar sus propias metas y alcanzarlas. La palabra "destino" hay que entenderla como el punto de llegada de la acción humana. Así, por ejemplo, el destino de un estudiante es ser ingeniero civil. Esta profesión es su meta o destino. Tiene derecho a estudiar en tal o cual universidad para obtener los conocimientos adecuados que le permitan realizarse en el campo propio de esa profesión.

\section{La ley natural en sentido moral como fundamento de los derechos humanos}

La ley natural moral es la que enuncia "haz el bien y evita el mal". El hombre llega al conocimiento de este principio - dice nuestro filósofo- porque reflexiona sobre la naturaleza humana, específicamente sobre la razón, principalmente la razón práctica. No se trata — aclara élde "la razón fría, estratégica y maquiavélica de la modernidad, sino de la razón recta" de que habla el aquinate, la cual está "inspirada por el conocimiento del bien y del fin del hombre". 
Este obra forma parte del acervo de la Biblioteca Jurídica Virtual del Instituto de Investigaciones Jurídicas de la UNAM www.juridicas.unam.mx

Ese bien o fin humano lo conoce la persona al través de sus inclinaciones, las cuales le muestran que, naturalmente, busca el bien y evita el mal. Tales inclinaciones las agrupa nuestro autor en tres clases:

a) Inclinación a la conservación propia, según la naturaleza; b) inclinación a la conservación de la especie por la procreación y educación de la prole, y c) inclinación al bien, correspondiente a la naturaleza racional, como el vivir en sociedad. ${ }^{22}$

Es un hecho de experiencia diaria que a nadie le agrada que le hagan cosas malas, y que a todo el mundo le gusta que le hagan el bien. Así que la máxima bonum faciendum, malum vitandum (el bien debe hacerse, el mal evitarse), no es vacía, sino que - al decir de Beuchot - adquiere contenido con el comportamiento humano. De modo que las inclinaciones humanas "sirven de elementos materiales con los que puede determinar desde su máxima generalidad", ${ }^{23}$ aplicando la máxima a circunstancias concretas de la vida individual.

La naturaleza humana — no está por demás recordarlo— la conoce el hombre por sus mismas operaciones: en el orden del conocimiento; lo primero que se conoce es el ser, en seguida se afirma de dos maneras: como existente y, entonces, se conoce uno de sus aspectos: la verdad; y se lo afirma, también, como apetecible, con lo que se descubre otra de sus características: la bondad. De aquí —dice él— que "el conocimiento del bien se pone en tercer lugar, después del conocimiento del ser y del conocimiento de la verdad". El ser es conocido por la razón teórica; el bien, por la razón práctica. Por eso, el movimiento de la voluntad sólo puede darse después del movimiento del conocimiento, ya que la persona primero conoce y luego quiere y se dirige hacia el bien.

La ley natural moral se funda en la razón práctica porque es la que conoce el bien y mueve a la voluntad hacia su acción propia: obtener realmente el bien.

El bien —dice Beuchot apoyándose en Santo Tomás- es lo que todos apetecen, pues el bien tiene razón de fin; por eso, el primer principio práctico es que el bien ha de ser procurado, y el mal, evitado. ${ }^{24}$

El cumplimiento de la ley natural está en función no de abstracciones, sino de una circunstancia concreta, ${ }^{25}$ de un momento específico en

24 Cfr. el mismo, Filosofía y derechos humanos..., p. 139.

25 Ibidem, p. 52. 
que se encuentra y vive cada quien. Esto, desde luego, no expresa que la ley natural moral sea arbitraria, ni que dependa del acuerdo entre los hombres; más bien significa que se adapta, objetivamente, a las necesidades de cada quien.

Pues bien - para nuestro filósofo- el derecho natural se funda en la naturaleza humana, porque la persona espontáneamente tiende hacia el bien. Con esto, el derecho natural, ontológicamente hablando, se funda en la dignidad y naturaleza humanas. ${ }^{26}$

\section{NECESIDAD DE FUNDAMENTAR EL DERECHO NATURAL}

La necesidad de comprender y comprobar que el derecho natural efectivamente brota del ser mismo del hombre, consiste — dice Beuchot- en evitar que tanto dichos derechos como su positivación sean independientes, en cuanto al respeto de que son objeto y suspensión injustificada de algunos de ellos, del arbitrio del legislador o del gobernante. En consecuencia, si los derechos naturales son comunes a todos los hombres, son anteriores e independientes a su positivación. ${ }^{27} \mathrm{Y}$ defienden al hombre incluso en contra de un derecho positivo injusto.

\section{RELACIÓN ENTRE DERECHO NATURAL Y FELICIDAD}

Por naturaleza, o sea espontáneamente, el hombre tiende y busca la felicidad. El derecho natural, o derechos humanos, tiene como finalidad, permitir que la persona se dirija hacia su propio fin, que es la felicidad, ${ }^{28}$ la cual le dará una razón para estudiar, trabajar, formar una familia, etcétera, $i$. e. la felicidad y, por ende, el respeto al derecho natural darán sentido a su vida.

\section{RELACIÓN ENTRE DERECHO NATURAL Y DERECHO POSITIVO}

Siguiendo el tomismo, Beuchot acepta que la función del derecho natural y, en consecuencia, la relación con el derecho positivo, es "iluminar con sus principios el ordenamiento del derecho positivo, de modo que, si 
éste lo contradice, será injusto". Así, el derecho positivo hállase fundado en el derecho natural y viene a ser como "una especie de cumplimiento suyo". 29

\section{CONCLUSIÓN}

El derecho natural no es otorgado, desde afuera, por las personas, sino, más bien, debe ser custodiado por ellas, para lo cual menester es inculcar en los estudiantes de los diversos grados de la educación (primaria, secundaria, preparatoria y profesional) qué es el derecho natural y cuáles son los derechos humanos, pues sólo quien conoce sus derechos los ejerce y los defiende.

Beuchot se afana por orientar su filosofía del derecho hacia los derechos humanos, y les da un fundamento iusnaturalista, de corte tomista, pero con elementos nuevos de la filosofía analítica, por ejemplo: la noción de clase natural, que habilita para hablar nuevamente de naturaleza o esencia; y defiende que el ser humano es una clase natural, subclase de las personas, y que no hay falacia naturalista en buscar en su estudio lo que después se establecerá como derechos humanos. 


\section{LOS DERECHOS HUMANOS Y EL FUNDAMENTO DE SU UNIVERSALIDAD}

SUMARIO: I. Introducción. II. El universal analógico y dialógico. III. Libertad, igualdad y fraternidad. IV. Universalidad relativa o analógica. V. Evaluación.

\section{INTRODUCCIÓN}

En este artículo me propongo abordar un problema principal que se plantea en cuanto a los derechos humanos. Se dice que son universales. Pero, ¿cuál es el fundamento de su universalidad? ¿Cómo puede legitimarse cognoscitivamente el que no estén sujetos a ser particularizados o relativizados a algún contexto dado? Aquí es donde se presenta el problema del modo como universalizamos esos derechos, cuál es el fundamento filosófico de dicha universalización.

Algunos autores en la actualidad han abominado la idea de la universalización. La ven como imposible, ilusoria, injustificada. Lo que se da es el individuo; y, con él, lo particular y lo diferente. Richard Rorty sostiene el particularismo, ${ }^{1}$ como resultado del cual llega al perspectivismo o relativismo. Derrida subraya la diferencia, y ve como empeño metafísico el querer homogeneizar o igualar, en lo cual consiste la universalización. Cerca de él caminan Lyotard y Vattimo, quejándose del esencialismo como adlátere de la universalización. Y la razón de fondo es que una universalización así arranca las diferencias y lleva a la igualdad impuesta y opresiva, como ellos aseveran.

Frente a ellos, intentaré proponer un modo de universalización que respete las diferencias de los hombres y de las culturas, y al mismo tiem-

1 R. Rorty no consigue librarse del particularismo y el relativismo, por más que quiera refugiarse en el pragmatismo. Cfr. Rorty, R., “Are Assertions Claims to Universal Validity?”, en C. B. Gutiérrez (ed.), El trabajo filosófico de hoy en el continente, Bogotá, Sociedad Iberoamericana de Filosofía-Sociedad Colombiana de Filosofía, 1995, pp. 71-82. 
Este obra forma parte del acervo de la Biblioteca Jurídica Virtual del Instituto de Investigaciones Jurídicas de la UNAM www.juridicas.unam.mx

po alcance la igualdad que sea posible lograr. Hay varios tipos de universalización, y defenderé sólo uno de ellos. Hay, fundamentalmente, una universalización univocista, otra equivocista y otra analógica. La univocista, completamente igualadora, es la que mantuvieron el positivismo, la fenomenología, el estructuralismo y otras formas de cientificismo que ahora son muy combatidas por los pensadores posmodernos. Por reacción contra ella, la mayoría de esos pensadores posmodernos se han entregado a la universalización equivocista, que es tan fragmentaria y atomizada, que no consigue reunir a los individuos en algo común, se diluye en la dispersión. De hecho acaba por no ser universalización. Pero, además de esas universalizaciones univocista y equivocista, creo que hay otra forma de universalizar: la universalización analógica, la del universal análogo, que respeta las diferencias pero las congrega en una aceptable unidad, la que — según Aristóteles - permitía seguir teniendo inferencias válidas. Una unidad bastante para poder seguir argumentando y fundamentando sin caer en el fundacionismo fuerte de la igualdad, de los univocistas, ni tampoco en el antifundacionismo fuerte de la diferencia, de los equivocistas.

\section{EL UNIVERSAL ANALÓGICO Y DIALÓGICO}

La universalización analógica, que conduce al universal análogo, consiste en congregar cognoscitivamente varios elementos respetando sus diferencias principales. Es un tipo de universalidad ya iniciado por Aristóteles con su idea de los términos parónimos y de la predicación o atribución pros hen, esto es, según algo uno que es primero, y que se realiza proporcionalmente en los sujetos a los que se aplica. Fue continuada su elaboración en el pensamiento medieval, para salvaguardar las diferencias de las cosas y los modos de ser. En el Renacimiento fue desarrollado por el célebre Cayetano, que tuvo muy en cuenta que lo análogo sólo tiene unidad proporcional, que ha de abstraerse o universalizarse de manera imperfecta y compleja, teniendo que rendir cuenta de los particulares analogados, de sus diferencias, de su riqueza. Me parece que se puede retrabajar en la actualidad el pensamiento y la argumentación analógicos de manera que nos conduzca a un tipo de universal diferenciado, que exige matización, que presenta y exhibe la distinción, y que también permite un mínimo de uniformidad suficiente, de manera que no invalide las inferencias.

Además, mi postura coincide en mucho con lo que dicen de la fundamentación de los derechos humanos los teóricos del diálogo y de los mí- 
Este obra forma parte del acervo de la Biblioteca Jurídica Virtual del Instituto de Investigaciones Jurídicas de la UNAM www.juridicas.unam.mx

https://biblio.juridicas.unam.mx/bjv

nimos morales, como Adela Cortina en España. De hecho, la universalización analógica requiere del diálogo no sólo para unificar, que es lo más fácil, sino para marcar las diferencias, los límites. Adela Cortina dice que los derechos humanos son los mínimos exigibles, a diferencia de los máximos con los que se tiene que convivir en una sociedad pluralista. ${ }^{2}$ Nos dice:

Pluralismo no significa obviamente "politeísmo axiológico", es decir, no significa que no haya entre los ciudadanos nada en común, sino todo lo contrario: precisamente el pluralismo es posible en una sociedad cuando sus miembros, a pesar de tener ideales morales distintos, tienen también en común unos mínimos morales que les parecen innegociables y a los que han ido llegando motu proprio y no por imposición. ${ }^{3}$

Y pone como ejemplo de eso los derechos humanos. Para ella, la universalización —en seguimiento de Apel— se logra por el diálogo. Un diálogo democrático y simétrico. Es como se llega a la intersubjetividad.

Eso es buscar un fundamento a la universalidad de los derechos humanos. En cambio, muchos teóricos posmodernos no conceden un fundamento "fuerte" (a veces ninguno) a tales derechos; pero con la misma arbitrariedad los defienden vehementemente. Yo todavía creo que se puede ofrecer un fundamento a los derechos humanos, en una utilización moderada, matizada y contextuada, de la razón. Un fundamento no tanto "débil" cuanto moderado, analógico. En efecto, hay que moderar muchas cosas que se han hecho en la fundamentación de los derechos humanos. Por ejemplo, Jesús Ballesteros ${ }^{4}$ hace una crítica de la idea de derecho subjetivo, porque le parece que está irremediablemente impregnada del individualismo moderno, es decir, del egoísmo que permea al liberalismo de todos los tiempos. 5 Son categorías capitalistas — dice- que ponen como paradigma el derecho de propiedad, alejados de la otra categoría de la solidaridad. No extraña que los derechos humanos, así planteados, tomen como modelo el derecho de propiedad para plantear los derechos a la vida, a la salud, a la libertad, etcétera. Todos ellos faltos de interconexión,

2 Cfr. Cortina, A., Ética civil y religión, Madrid, PPC, 1995, pp. 70-71.

3 Ibidem, p. 70.

4 Cfr. Ballesteros, J., Postmodernidad: decadencia o resistencia, Madrid, Tecnos, 1989, pp. 54-65.

5 Cfr. Saldaña, J., "Críticas en torno del derecho subjetivo como concepto de derechos humanos”, Boletín Mexicano de Derecho Comparado, México, núm. 86, UNAM, 1996, pp. 685-706. 
Este obra forma parte del acervo de la Biblioteca Jurídica Virtual del Instituto de Investigaciones Jurídicas de la UNAM www.juridicas.unam.mx

que sólo les podría dar la solidaridad. Son propiedades o libertades que el individuo hace valer, pero que no comparte con sus semejantes, y por ello no tiene la idea de poner en común la tierra, el trabajo, la libertad misma, la persona.

\section{LIBERTAD, IGUALDAD Y FRATERNIDAD}

Jesús Ballesteros señala la oposición que se da entre libertad e igualdad; si se me obliga a ser igual ya no estoy siendo completamente libre, y trata de marcar límites a una y a otra, para que no se relacionen con una disyuntiva, sino con una conjunción. Estoy de acuerdo con él en cuanto a esa relación de la igualdad y la libertad; pero me da la impresión de que Ballesteros no destaca lo suficiente el tercer elemento que iba en la modernidad junto a la igualdad y la libertad, a saber: la fraternidad. Esto se remonta a los mismos lemas de la modernidad. En efecto, la Revolución francesa proclamó tres cosas: igualdad, libertad y fraternidad. Se logró algo en el terreno de la igualdad y de la libertad; pero parece no haberse logrado casi nada en el terreno de la fraternidad. Por ello, el igualitarismo y el liberalismo modernos tienen pendiente la fraternidad, que es la única que podría contrarrestar el individualismo engendrado por el liberalismo y el competitivismo engendrado por el igualitarismo. En efecto, esos lemas tuvieron efectos contrarios a los que se esperaba de ellos. El ansia de igualdad llevó a querer sobresalir; no se contentó el hombre moderno con ser igual a los otros, con la democracia, sino que ello le daba una base firme para procurar superar a los otros. Además, el ansia de libertad, que no se contentó con la libertad de pensamiento y de acción dentro de los límites del bien común, pasó a proclamar la libre empresa, el libre comercio y la libre competencia. La libre empresa ocasiona el poder producir lo que se quiera, aunque no sirva a la comunidad; más aún, aunque agote la tierra y dañe la ecología. El libre comercio ocasionó que el hombre deseara vender lo que quisiera, sin importar si se trataba de necesidades inducidas. La libre competencia ocasionó que se buscara destruir a los rivales, llevarlos a la bancarrota o absorberlos. Todo ese individualismo carece del sentido de la solidaridad, que está asociada al ideal de la fraternidad. Hace falta, por tanto, inyectar ese ideal a la noción de derecho, y tal vez no llegar, como lo hace Ballesteros, a buscar una noción de derechos que dejen de ser subjetivos y se hagan comunitarios, sino tratar de hacer que nuestra noción de derechos subjetivos pueda desligarse de su heren- 
cia individualista y liberalista, y pueda conectarse con algo más objetivo y comunitario, a través de la solidaridad con los demás. Sin renunciar a su carácter subjetivo, señalar su dependencia de lo objetivo, que se da en las relaciones con los demás, en el ámbito comunitario, que es donde puede ejercerse la solidaridad. La fraternidad, me parece, en la medida en que se logre, equilibrará la igualdad y la libertad, que se tensionan entre sí, y llevará a lo que quisiera llamar equidad analógica, proporcional.

Hay algo, sin embargo, que me parece muy acertado en el análisis de Jesús Ballesteros, y es el que pida suplir el modelo de propiedad, que tienen los derechos humanos, por el modelo de la calidad de vida, la cual puede ser compartida por todos. Propone que, en lugar de hablar de lo inviolable, se hable de lo inalienable. Dice: "En efecto, ahora de lo que se trata no es tanto de defender los derechos frente al Estado como en el caso de la 'libertad de los modernos' o derechos de la primera generación, sino de defenderlos frente al mercado, e incluso frente a la propia voluntad individual del sujeto de los mismos" ${ }^{6}$ Con esto se podrían evitar muchos conflictos entre los mismos derechos humanos, por ejemplo, cuando se alega el derecho a la vida para no morir defendiendo a la patria, o cuando se alega el derecho a la vida de algunos para permitir la eutanasia o el aborto. Estos dos últimos casos son señalados por el propio Ballesteros. Explica:

De la visión integral del hombre como siendo también su propio cuerpo se desprende naturalmente la monstruosidad de la pena de muerte, de la tortura, que han podido ser presentadas históricamente como lícitas, apelando a la irrelevancia antropológica del cuerpo, pero igualmente de la eutanasia y del suicidio, y mucho más la del aborto, ya que, en este caso, del cuerpo que se pretende disponer no es siquiera de la mujer, sino del propio hijo. En el fondo, el problema del aborto se encuentra íntimamente relacionado con el de la paternidad artificial. En ambos casos, aunque de distinto modo, se piensa que la paternidad es un derecho subjetivo, algo de lo que disponemos positiva o negativamente a placer. Es, por el contrario, un derecho moral, una obligación de apertura a la vida, que excluye toda frivolidad o capricho. Tanto más repugnante es la introducción en estos temas de elementos de carácter lucrativo [por ejemplo, el comercio de órganos]. ${ }^{7}$ 
Este obra forma parte del acervo de la Biblioteca Jurídica Virtual del Instituto de Investigaciones Jurídicas de la UNAM www.juridicas.unam.mx

Creo que una postura que promueva la introducción de la solidaridad o fraternidad puede limar las colisiones entre la libertad y la igualdad, mediante la nueva conjunción del derecho y el deber, que la modernidad había separado. También por la conjunción de la economía y la política, que en el fondo es un sujetar el capitalismo a la democracia. ${ }^{8} \mathrm{Y}$ yo añadiría que de lo que más se trata es de no desconectar la política del derecho y el derecho de la moral o la ética. Esto es algo que ya se viene subsanando, al menos en parte, mediante la idea de derechos morales (moral rights), en la que algunos nuevos teóricos han querido fundamentar filosóficamente los derechos humanos (por ejemplo, Eusebio Fernández y Carlos Santiago Nino). ${ }^{9}$

Pero, en cuanto a los mismos posmodernos que Ballesteros coloca en la posmodernidad como decadencia, no en la posmodernidad como resistencia (frente a muchos antivalores de la modernidad), encuentro que no se atreven a negar la validez de los derechos humanos, a pesar de que su particularismo, relativismo y nominalismo tendrían que llevarlos a ello. Así, en una entrevista de 1993, Jean François Lyotard proclama que debe salvaguardarse algo común a todos los seres humanos, cosa que apoyaría esos derechos universales de los hombres. ${ }^{10}$

\section{UNIVERSALIDAD RELATIVA O ANALÓGICA}

Aquí volvemos a ver el problema de la universalidad de estos derechos. Yo he querido hacer ver, en repetidas ocasiones, que la universalidad se dice de muchas maneras, que hay varios tipos de universalidad. Uno de ellos es el del universal unívoco, otro el del equívoco y otro el del analógico. Yo estoy por esta última universalidad, la del universal análogo, proporcional. Me parece que esto se acerca a, y se ve apoyado por, lo que Wolfgang Huber, profesor de ética en Heidelberg, llama "universalidad relativa". En cuanto a los derechos humanos, trata de evitar la universalidad absoluta al igual que la particularidad absoluta. La primera supone que las intuiciones éticas de la cultura europea son universalizables

8 Cfr. ibidem, p. 156.

9 Cfr. Fernández, E., Teoría de la justicia y derechos humanos, Madrid, Debate, 1984; y Nino, C. S., Ética y derechos humanos. Un ensayo de fundamentación, Buenos Aires, Paidós, 1984.

10 De esa manera Lyotard quiere salvar el humanismo en contra de la tecnocracia. Cfr. Gruagnuolo, B., "Jean François Lyotard. Capitalismo a la Marx", El Mercurio, suplemento Artes y Letras, Santiago de Chile, 24 de octubre de 1993, pp. 8-9. 
para todas las culturas, y que las que no las aceptan lo hacen por su nivel cultural inferior. La segunda ha surgido de las críticas relativistas a los derechos humanos. Los relativistas dicen que las convicciones morales sólo son válidas dentro del entorno cultural en el que surgieron. Pero, así como la primera postura puede ser acusada de imperialismo o colonialismo cultural, esta segunda puede serlo a su vez de cerrazón o chauvinismo cultural. De hecho encontramos que ninguna cultura puede cerrarse en sí misma, y que tiene intersecciones, en muchos aspectos, con las demás, al menos con algunas, e incluso cada vez con más de ellas, ahora lanzada vertiginosamente por los medios de comunicación. Y eso alcanza a universalizar, así sea de una manera relativa y sólo multicultural. Ni uniculturalismo ni relativismo, sino multiculturalismo. Wolfgang Huber le da el nombre de "universalidad relativa", que creo coincidente con lo que yo llamo universalidad analógica. Huber aduce dos razones para su uso de esa expresión de la universalidad relativa. Explica:

Comparada con un relativismo radical, representa la necesidad y posibilidad de intuiciones éticas que trasciendan las culturas y las religiones, y que sean tan básicas que puedan llegar a ser legalmente compulsivas. Comparada con un universalismo radical, sin embargo, representa el hecho de que las intuiciones éticas y las normas legales son sólo preliminares en términos históricos y por consiguiente relativas. El consenso sobre tales intuiciones surge de la diversidad y de la riqueza de las tradiciones culturales y de las creencias religiosas. Tiene que estar firmemente anclada en esta diversidad y debe estar embebida en ella una y otra vez. ${ }^{11}$

Me parece que eso coincide con la analogía en su intención de respetar las características principales de los elementos del conjunto, los particulares de ese universal. Huber sigue diciendo:

Todo el que quiera reforzar la validez universal de las intuiciones éticas y los estándares de los derechos humanos tiene que ser receptivo con las peculiaridades de estas tradiciones y convicciones. Los que quieran reducir las tradiciones religiosas y culturales a sus enunciados comunes bloquearán las fuentes de las cuales puede brotar un ethos planetario. Todos los que desean llevar la diversidad de las religiones [y de las culturas] al lecho de Procusto de una comprensión común de la religión [y

11 Huber, W., “Winning the Future. We Need a Planetary Ethics”, Universitas, vol. 35, núm. 3, 1993, p. 165. 
Este obra forma parte del acervo de la Biblioteca Jurídica Virtual del Instituto de Investigaciones Jurídicas de la UNAM www.juridicas.unam.mx

de la cultura], privarán al diálogo interreligioso [e intercultural] de su dimensión más decisiva. ${ }^{12}$

La universalización lleva siempre sobre ella la espada de Damocles del etnocentrismo, pero la particularización lleva la del relativismo insostenible y absurdo. Se impone una postura intermedia, que, sin perder la consideración de las diferencias, permita lo máximo de universalidad. Pero tampoco se pueden aplicar indiscriminadamente en la práctica, pues hay conflictos y dilemas. No se pueden pensar los derechos humanos sin algún tipo de universalidad. Lo que me parece más exacto es decir que esa tensión entre lo universal y lo particular de los derechos humanos se equilibra no postulando que es algo que se va acordando en cada contexto y por eso se hace universal, sino que se va acordando en cada contexto precisamente porque es universal. Ésa es la prueba de su universalidad; es algo universal que se va adaptando y va adquiriendo matices particulares en cada contexto. No creo que ésta sea una distinción trivial o inútil; de ese cambio de perspectiva depende toda una visión filosófica de la realidad.

Además, la manera de universalizar, esto es, de lograr la universalidad, es distinta en el ámbito teórico y en el práctico. En el teórico se puede hacer de manera más precisa. En todo caso, en el práctico se requiere de más diálogo y persuasión. Por eso Aristóteles pensaba la retórica y la tópica como argumentaciones más eminentemente prácticas, sobre todo en la ética. ${ }^{13}$ Aquí es donde más se tiene que hablar de un universal analógico, proporcional y diferenciado, bien ponderado en su aplicación a los individuos según la diversa porción aplicable a cada uno. Allí las normas exigen un cumplimiento analógico, matizado, prudencial; no se pueden aplicar de manera unívoca, porque sería a seres ideales, ni tampoco de manera equívoca, porque no habría punto de comunicación. Mas también aquí se logra universalidad por el interés en el otro, en los otros, en los muchos, en los más; y se trata de una universalización apoyada por la benevolencia, la amistad, el ágape, la ayuda, por la solidaridad, en aquello que antes se llamaba el bien común, más allá de la sola preocupación por el bien particular. Y es la praxis apoyando la teoría, inclusive lo afectivo apoyando a lo conceptual.

13 Cfr. Camps, V., Ética, retórica, política, Madrid, Alianza, 1988, pp. 35 y ss. 
Se ha querido que a la moral de leyes la suceda ahora una moral de virtudes. Y se piensa que las virtudes, a fuer de resultados del ejercicio práctico, casi inconsciente, no requiere de leyes ni de reglas. Pero, aplicando la analogía, se puede decir que las virtudes no están reñidas con un mínimo de leyes, de principios. Los principios, leyes y reglas son para las virtudes una indicación, una invitación, un camino a seguir, más que una prescripción dura. Es el hombre el que las aplica, analógica o prudencialmente, a los casos concretos, con sus diferentes circunstancias, a las situaciones, según la proporcionalidad que conviene. De este modo se va formando y fortaleciendo la virtud moral. Se tiene, así, una universalidad analógica de la ley, que se hace concreta según el contexto de la circunstancia, y va configurando la virtud, que cada vez aplica mejor esas pocas leyes que la orientan, cada vez con más perfecta analogicidad o proporcionalidad más precisa.

Así veo también a los derechos humanos, universales por su pertenencia a la virtud de la justicia, virtud moral y práctica, que inclina y mueve de modo universal. La justicia, o se universaliza o no es justicia, pero no se universaliza de modo igual, es proporcional o analógica. Tiene que ser aplicada por otra virtud, la de la prudencia, en este caso iuris-prudentia, a los casos particulares, sobre todo en los que llevan conflicto entre derechos y los que conllevan dilemas acerca de los mismos. Esos casos se podrán resolver con equidad, que es lo mismo que la justicia; pero es una igualdad proporcional, analógica, prudencial. Es la virtud de la prudencia asistiendo a la de la justicia, en la misma estructura humana, como un hábito, desplegando su dinamismo de una manera armónica, armoniosa, por todo un proceso largo y arduo, pero también inclinante y esperanzador; proceso que en las sociedades y las personas no es otra cosa que el difícil camino de la virtud.

\section{EVALUACIÓN}

Ardua labor la de buscar los fundamentos de la universalidad de los derechos humanos. Pero si no tiene algún tipo de universalidad, es claro que no funcionarán como tales derechos. ¿De dónde se puede obtener esa universalización? Creo que si planteamos esa universalidad como fruto de una abstracción que no traicione la complejidad de lo concreto y particular, habrá que hablar de una abstracción analógica, que nos deparará un universal analógico, bien diferenciado y cribado, pero que de ninguna 
manera se pierde en los relativismos que lo amenazan. Nos da un pluralismo, pero el pluralismo es distinto según el punto de vista desde el cual se enfoque. Puede ser visto desde la univocidad, y pugnará por homogeneizar; puede ser visto desde la equivocidad, y tenderá a disgregar irreductiblemente; o puede ser visto desde la analogicidad, y vivirá de la tensión que se establece entre la intencionalidad de reunir las diferencias en la unidad y la intencionalidad de dar cuenta cuidadosa de las diferencias unificadas. 


\title{
IGUALDAD Y SIMETRÍA: LA SELECCIÓN DE LOS DERECHOS
}

Francisco CARPINTERO

\begin{abstract}
SUMARIO: I. La razón de hoy, que es la ilustrada. II. Kant tuvo sus propias ideas. III. La separación del derecho y la moral. IV. "Una posibilidad siempre presente”. V. Un epílogo posible.
\end{abstract}

No somos pasivos frente a nuestros derechos: no nos limitamos a decir "éstos son...". Los seleccionamos de acuerdo con las exigencias de nuestro momento cultural, que ha seguido definitivamente el camino de la Modernidad. Samuel Pufendorf indicó la meta: el fin de la vida práctica es hacer posible la libertad individual, que ha de ser lo más amplia posible. ${ }^{1}$ Mostró estas exigencias como realidades humanas ya constituidas, a las que dio el nombre de "cualidades morales". Locke añadió a esta igual libertad la tercera cualidad moral indispensable en la sociedad capitalista: el derecho individual a la propiedad privada. ${ }^{2}$ Así entraron en los comienzos del siglo XVIII los tres derechos fundamentales del hombre. La función del "Estado" (con mayúscula, porque es nombre propio) era la de garantizar en el estado hipotético de convivencia los derechos que los hombres ya poseían en el status naturae, que era el momento del estado absoluto del derecho natural. A causa de esta tarea aseguradora el

1 Este alemán propuso entender la libertad como un status, concretamente "Sic v.g. libertas pro statu concipitur ad analogiam spatii; pro facultate agendi ad modum qualitatis activae". Cfr. De iure naturae et gentium libri octo, Francofurti et Lipsiae, 1759, 1. I, cap. 1, 11, p. 11. En el 19 explica que esta cualidad moral "est enim maxime velut diffusiva sui".

2 Locke siguió estrechamente las ideas de Hobbes y Pufendorf sobre la naturaleza de la "ley" natural, que sólo crea derechos, no deberes. Vid. el 87 de su Segundo ensayo. A partir del 90 de esta obra, cambia su tono sobre la cantidad de propiedad inmobiliaria que cada cual puede poseer, y legitima el régimen existente. En el 121 enunció el principio que bastante más tarde seguirían los kantianos, a saber: que los derechos civiles dependen de la condición de propietario: "Ahora bien, no teniendo el gobierno jurisdicción directa sino sobre la tierra, y no alcanzando esta jurisdicción al poseedor de la misma [...] sino mientras vive en dicho Estado y disfruta de dichas tierras, la obligación que tiene por el disfrute de vivir sometido al gobierno empieza y acaba con ese disfrute". 
Este obra forma parte del acervo de la Biblioteca Jurídica Virtual del Instituto de Investigaciones Jurídicas de la UNAM www.juridicas.unam.mx

https://biblio.juridicas.unam.mx/bjv

Estado, ${ }^{3}$ pronto los alemanes le dieron el nombre de Rechtsstaat, o "Estado de derecho", porque su finalidad era proteger los derechos que peligraban en el estado de naturaleza. ${ }^{4}$

Después de las críticas socialistas, hoy son pocos los universitarios que contemplan la propiedad como un derecho individual básico. Pero ha permanecido la exigencia de la igual libertad como el elemento más que básico, y nuestras éticas universitarias son imprescindiblemente éticas dialógicas, porque académicamente es impensable la vuelta a una "moral" que imponga deberes heterónomamente. Los sujetos que dialogan son los seres individuales, por más que Habermas hable de unos extraños intereses emancipatorios que no son ni históricos ni trascendentales, sino cuasitrascendentales. En cualquier caso, a pesar de los intereses cuasi trascendentales habermasianos, Apel, Habermas o Rawls solamente tienen en cuenta la igual libertad individual de los seres humanos, y parece que éste ha de ser hoy el punto de partida de toda teoría de la justicia.

Este hecho deja al jurista algo perplejo. Porque los que nos hemos engolfado con varias ramas del derecho civil y mercantil observamos una variedad de situaciones decisivas para el enjuiciamiento, que no pueden ser explicadas desde las posibilidades excesivamente angostas de la igualdad personal. 5

3 Adam Smith advertía que "The appropiation of hards and flocks, which introduced an inequality of fortune, was that which first gave rise to regular government. Till there be property the can be no government, the very end of which is to secure wealth, and to defend the rich from the poor". Cfr. Lectures on Jurisprudence, Oxford, Clarendon Press, 1978, p. 404. Era lógico que John Austin, un siglo después, hiciera notar que la gente creía que los gobiernos sólo existen para proteger la propiedad: "It is commonly said that Government exist or should exist to institute and protect property". Cfr. Lectures on Jurisprudence or Philosophy of Positive Law, London, $5^{\text {a }}$ ed., 1911, p. 791.

4 Paul Johann Anselm Feuerbach explicaba que Kant no propugnó ninguna tiranía: “In Kant findet man keinen Vertheidigen dieser Ausdehnung der höchsten Gewalt [...] In wie ferne ist also dieser Anti-Hobbes auch ein Anti-Kant? Offenbar nicht in so ferne, dass der Regent, als blosse Privatperson nicht unverletzlich sey: dann das Gegentheil hievon ist Kants Behauptung nicht". Cfr. Anti-Hobbes oder über die Grenzen der höchsten Gewalt und das Zwangsrecht der Bürger gegen den Oberherrn. Erfurt, 1798, pp. 84 y 86. Feuerbach hacía esta precisión porque Kant propugnó la sumisión incondicional de los súbditos al poder político: vid. Principios metafísicos de la doctrina del derecho, edición de A. Córdova. No consta traductor, México, UNAM, 1978, pp. 149 y ss. La razón que movía a Feuerbach a exponer esta tesis era que en la sociedad política kantiana el "Regent" estaba incondicionalmente al servicio de los fines de la sociedad: vid. op. cit., p. 95, por ejemplo.

5 La palabra "persona" significó en la jurisprudencia romanista el conjunto de derechos y obligaciones — competencias- que eran originadas por cada situación jurídicamente relevante. En la Edad Moderna pasó a significar el ser independiente y autónomo que no reconoce superior y que únicamente puede quedar obligado cuando él presta libremente su consentimiento mediante un pacto. Vid. mi estudio "La independencia y autonomía del individuo: los orígenes de la 'persona jurídica"”, Anuario de Filosofía del Derecho, Madrid, IV, 1987, pp. 477-522. Un estudio más comparativo 
Este obra forma parte del acervo de la Biblioteca Jurídica Virtual del Instituto de Investigaciones Jurídicas de la UNAM www.juridicas.unam.mx

https://biblio.juridicas.unam.mx/bjv

La pregunta decisiva acaba recayendo: ¿por qué hemos de limitarnos a este dato? Note el lector que actualmente éste es el único derecho humano que posee prestigio y operatividad tanto dentro como fuera de los ámbitos académicos. No he hecho cálculos precisos, pero observo que en la jurisprudencia del Tribunal Constitucional español, el escueto artículo 14 de la Constitución española vigente, que establece la igualdad personal, es inconmensurablemente más alegado que cualquier otra disposición de la Constitución.

Las éticas dialógicas reposan sobre "la generalización propia del imperativo categórico kantiano". Y de la mano de este imperativo categórico han resucitado académicamente a Bentham y, con el matrimonio de Kant y Bentham, han dado vida a un nuevo y extraño "Principle of utility". Porque Bentham solo no puede aguantar: el inglés resulta demasiado $\operatorname{tosco}^{6} \mathrm{y}$ materialista para los tiempos que corren. Es preciso añadirle un toque normativo con el postulado del "fin en sí mismo" que corresponde a todo hombre según la filosofía kantiana. Siempre ha sido una constante introducir un matiz trascendental a lo que parece que es ante todo simple. ${ }^{7}$ Hay quienes van algo más allá y proponen hermanar la generalización de la propuesta kantiana, tal como aparece de modo sui generis en Rawls, por ejemplo, con un mordisco normativo. Esto es demasiado: es como tomarse en serio los intereses cuasitrascendentales de Habermas. ${ }^{8}$

con otras realidades análogas lo he publicado más recientemente: “Persona y 'officium': derechos y competencias", Rivista Internazionale de Filosofia del Diritto, LXXIII, 1996, pp. 3-59.

Francis Hutcheson explicaba con precisión que "Status est 'Hominis condictio permanens, varia iura, et longam obligationem seriem includens': Estque vel 'solutus et liber' quem constituit ipsa natura; vel 'adventitius', ab aliquo hominum instituto ortus". Cfr. Philosophia moralis institutio compendiaria, libris III, Glasgow, 1745, p. 144. La noción de status es sinónima de la de 'persona' u officium.

6 Bentham es realmente grosero en sus exposiciones. Demasiado desinhibido, falta al respeto a sus interlocutores, a los que frecuentemente descalifica mediante ironías.

7 John Stuart Mill ya hablaba de un "Eudemonismo trascendental" para referirse a lo que según Lorimer no era más que un hedonismo grosero. James Lorimer escribía: "Mr. Mill, in his latter writings, has sublimated utilitarism into something might be called Trascendental-Eudaemonism". En nota a pie explica: "In a interesting passage in his Autobiography, p. 189, he even speakes of the 'highest realizable ideal of human life' as a true object of human endeavour, though how this ideal should have possesed such valve in the eyes of one who regarded 'the pretended perfection of the order of nature and of the universe' as a 'superstition' is not explained". Cfr. The Institutes of Law, $2^{\mathrm{a}}$ ed., Edimburgh, 1880, p. 48.

8 En estos temas prefiero seguir el parecer del normalmente muy juicioso James Harrington cuando entendía que "That which I would infer from all this, is, that the generality of speculative men, for the most part guiding their understanding by those notions which they find in books, fall not seldom by this means into considerable errors". Cfr. "The Grounds and Reasons of Monarchy", The Oceana and Other Works, London, 1771, p. 5. 
Este obra forma parte del acervo de la Biblioteca Jurídica Virtual del Instituto de Investigaciones Jurídicas de la UNAM www.juridicas.unam.mx

Este batiburrillo de problemas y éticas procedimentales plantea perplejidades al jurista, y quisiera aludir a ellas muy grosso modo. Una de ellas podría consistir en que, según estos nuevos sistemas de ética, la razón humana es sólo una función que surge desde la conjunción de las libertades personales con los intereses igualmente individuales. Como el derecho no puede reconocer sin más todo tipo de intereses, la razón se desgrana en unas generalidades lingüísticas, que pretenden ser normativas, y que cada autor construye como puede. Por lo general, esta nueva razón que habita en el lenguaje, ha propuesto desde el siglo XVIII hasta hoy unas éticas utilitaristas (ahora hermanadas con los personales "fines en sí mismos") que no dejan de plantear problemas.

Como podemos jugar con las palabras llegando a un diálogo en el que nadie oye, creo que es preferible clarificar qué es esa "generalidad propia del imperativo categórico kantiano" que tantos toman como punto de referencia obligado. ${ }^{9}$ Y como la razón pura que usan estos teóricos de la justicia, que es solamente una secuela de la libertad individual, únicamente posee como palancas para poder avanzar, una mixtura de ética dialógica y de intereses individuales, me gustaría echar mi cuarto a espadas también sobre ella. Todo esto es un simple esbozo: pero el profesor de dibujo me enseñó, allá por mis quince años, que es mejor hacer un esbozo previo antes de dibujar un objeto entero. No es cuestión de discutir con él.

\section{LA RAZÓN DE HOY, QUE ES LA ILUSTRADA}

1. Kant fue el primer filósofo que pretendió una Razón pura, esto es, autónoma respecto del mundo sensible (el Sinnenwelt) y autosubsistente: una asignatura pendiente desde Descartes. El filósofo francés no la logró, sino que más bien consiguió que las filosofías de sus epígonos se movieran por campos idealistas, y la reacción de los ilustrados contra él y sus discípulos tomó un camino lógico y previsible: un talante sensista y fenomenista que no podía conocer ninguna eticidad en el sentido propio de esta palabra, según Kant.

9 Así era entendido desde antiguo el "imperativo categórico" de Kant. Carleton Kemp Allen escribía, en 1931, refiriéndose a Kant, que "This necessarily involved a harmony, or the constant attempt at harmony, between the individual and his fellow-members of society, from whom he can never be separated by practical reasons [...] Man has to conform his particular to his universal nature; and this involved the double task of establishing withim himself a harmony of the particular desires to reason and of conforming his relations as a principle of social unity". Cfr. Legal Duties and Other Essays on Jurisprudence, Oxford, Clarendon Press, 1931, p. 114. 
Este obra forma parte del acervo de la Biblioteca Jurídica Virtual del Instituto de Investigaciones Jurídicas de la UNAM www.juridicas.unam.mx

https://biblio.juridicas.unam.mx/bjv

De ahí las “utilidades” de Helvetius, D’Holbach, Hume o Bentham, como sucedáneos de la moralidad perdida. ${ }^{10}$ Mantener que el "principio de utilidad" constituye una moral parece estirar demasiado el significado posible de las palabras. ${ }^{11}$ Porque tenía razón Antonio Rosmini-Serbati cuando indicaba que la utilidad es un hecho, del mismo modo que las sensaciones, mientras que la justicia es una idea: "la justicia es un principio, y la utilidad es una consecuencia". ${ }^{12}$

Para hacer justicia hay que partir desde la justicia, desde su idea al menos, y llegar a unas consecuencias. Pero prescindir de esta idea y erigir a unas utilidades en el verdadero rostro de la justicia, es prescindir de lo más humano. Y los hombres no acabamos de entendernos a nosotros si prescindimos de lo humano. Dicho en términos más filosóficos: ¿cuál es el estatuto normativo de los sistemas de ética que nos han regalado los filósofos desde el siglo XVIII hasta hoy? Porque vemos mucha racionali$\mathrm{dad}$ en ellos, pero poco entronque con el hombre real y concreto que no se deja atrapar desde las estadísticas.

Además (visto el problema desde otro punto de vista), siempre permanecerá en pie la observación de James Lorimer: "just as the utilitarian assumes our knowledge of what is expedient or useful? The difficult is always with the what". ${ }^{13}$ La mentalidad que subyace a las "esferas de libertad" podría señalar que ese "what" lo determina cada cual personalmente; pero entonces hay que renunciar a toda pretensión de una moral social.

La crítica kantiana estaba justificada en su momento histórico, y ahora, y no es mala idea revisar esta razón que está en la base de sistemas éticos tan distintos.

10 Paul Henri Thiry, Baron d'Holbach, proporcionaba una noción de deber u obligación que cabalmente no puede ser entendida como un deber en el sentido usual del término: "L'obligation morale est la necessité de faire ou d'éviter des certains actions en vue du bien-être que nous cherchons dans la vie sociale". Cfr. La morale universelle ou les devoirs de l'homme fondées sur sa nature, Amsterdam, 1776, libro I, p. 2.

11 James Lorimer explicaba que "The utilitarian doctrine: if we reply to it by the question, 'Useful for what actions are means, not ends, and their quality can be tested only by reference to some final end or object (telos) [...] If the rule be, 'follow virtue', 'follow pleasure', 'follow nature', the realisation of whatever we may cloose to characterize as 'virtue', or 'pleasure', or 'nature', is the object of the rule [...] But 'follow utility' is a rule which has no object [...] the utilitarian system furnishes no test at all”. Cfr. The Institutes of Law, cit., p. 48.

12 "La giustizia é un principio, l'utilità é una conseguenza", Rosmini-Serbati, Filosofia del diritto, cit., p. 9.

13 The Institutes of Law, cit., p. 194. 
Este obra forma parte del acervo de la Biblioteca Jurídica Virtual del Instituto de Investigaciones Jurídicas de la UNAM www.juridicas.unam.mx

https://biblio.juridicas.unam.mx/bjv

FRANCISCO CARPINTERO

2. Indicaba que Kant quiso poner en marcha la razón pura desde sí misma, superando el cálculo de utilidades de los sujetos individuales. Parecía considerar que los intentos sensistas de los francófonos e ingleses sólo llegaban a producir cosas útiles para los hombres, pero no cosas que fueran necesariamente humanas. En cierto modo, Kant quiso rehabilitar la conciencia, perdida en los sistemas de derecho natural y de ética ilustrados. ${ }^{14}$ Sólo que no podía recurrir sin más a la conciencia moral clásica, desprestigiada en el movimiento secularizador: él trató de diseñar una conciencia moral secularizada, que partiera desde sí misma, sin apoyaturas en datos que no fueran suministrados exclusivamente por la razón $a$ priori.

En su Crítica de la razón pura mostró sin demasiados remilgos los resortes secretos de la nueva máquina (del mundo nouménico que él había diseñado), del movimiento incausado y perpetuo, siempre necesario, de la razón, movido por las leyes fundamentales de la mecánica cartesiana: la exigencia de plenitud espacial, ${ }^{15}$ determinada por el horror vacui. ${ }^{16}$

3. El tema es complejo, y se impone abordarlo desde distintos "principios del entendimiento", según se expresaba Hegel. Porque la racionalidad pura a priori que inventó Kant, y en cuya idea (tal como es entendida usualmente) se inspiran las racionalidades prácticas que ahora surgen tan

14 Lord Kames ya escribía que "This is a true which has been little attended to by those who have given us systems of natural law". Se refería al escamoteo de la conciencia moral. Cfr. Essays on the Principles of Morality and Natural Religion, London, 1758, p. 57.

15 La idea del "Sistema" determinaba esta plenitud. Un texto, entre muchos, en el que expone esta tesis podría ser este: "Si echamos una ojeada a nuestros conocimientos del entendimiento en toda su extensión, vemos que lo peculiar de la razón a este respecto, lo que ella intenta lograr, es la sistematización del conocimiento, es decir, su interconexión a partir de un solo principio". Cfr. Crítica de la razón pura, trad. de Pedro Ribó, Madrid, Alfaguara, 1988, A 645, p. 532 de esta edición. Más rotunda, pero quizá menos preciso, en A 323: "Consiguientemente, todas las ideas trascendentales podrán reducirse a a tres clases: la primera de ellas incluirá la unidad absoluta (incondicionada) del sujeto pensante; la segunda, la unidad absoluta de la serie de las condiciones del fenómeno; la tercera, la necesidad absoluta de la condición de todos los objetos del pensamiento en general'. El enfásis es de Kant.

Es más claro en la Rechtslehre que forma la segunda parte de la "Metafísica de las costumbres". Allí indicaba que "La ley de una obligación mutua [...] es en cierto modo la 'construcción' de esta noción del derecho, es decir, de su exposición en una intuición pura a priori según la analogía de la posibilidad de los movimientos libres de los cuerpos sometidos a la ley general de la acción y de la reacción". Cfr. Principios metafísicos de la doctrina del derecho, edición de A. Córdova, México, UNAM, 1978, p. 35.

16 "Non datur vacuum formarum; es decir, no hay diferentes géneros originarios y primeros que se hallen, por así decirlo, aislados y separados (por un intervalo vacío), sino que todos los diferentes géneros son simples divisiones de un único género supremo y universal". Cfr. Crítica de la razón pura, cit., A 659, p. 541. En A 661 indica que este continuum no es observable en la naturaleza, en donde hay un quantum discretum. 
Este obra forma parte del acervo de la Biblioteca Jurídica Virtual del Instituto de Investigaciones Jurídicas de la UNAM www.juridicas.unam.mx

https://biblio.juridicas.unam.mx/bjv

frecuentemente, no se deja atrapar desde un único punto de vista. Advierto al lector ante un discurso quebradizo.

Indicaba que los "sistemas de ética" utilitaristas de la Ilustración han cojeado por su insuficiencia. Demasiado psicologismo: ya en Helvetius la "razón” está al servicio de algunas pasiones del hombre. La ética devino psicología de masas.

4. Pero los constructos de base psicologista parecen hoy incompletos, esto es, insuficientes, o insuficientemente sistemáticos: una época cuya filosofía aspira a la plenitud del conocimiento (quiere explicarlo todo desde el único punto de vista posible) reclama plenitud, y los filósofos (¡extraña clase profesional!) sólo llegan a esta exigencia a través del postulado del sistema. Por este motivo, tras el éxito momentáneo de la Ilustración, nuestros filósofos actuales parecen entender que lo psicológico ha de ser completado con una filosofía más racional, esto es, con un discurso que posea más empaque abstracto y más cerrazón lógica. Hay que revalidar el éxito de Protágoras, a quien Platón no pudo vencer argumentativamente. El conocimiento directo de la realidad humana ha quedado otra vez arrumbado, y es preciso argumentar.

5. Ahora, a finales de siglo, terminado el talante del positivismo lógico, nuestro revertimini ad rationalem simplifica notablemente a Kant: de su filosofía sólo ha quedado la exigencia de igualdad personal, en cierto modo ya contenida en la tesis del Selbstzweck y la "generalidad propia del imperativo categórico kantiano".

Hemos simplificado a Kant: en vano buscaremos hoy referencias a Platón, el único autor al que Kant citaba elogiosamente, ${ }^{17}$ ni un universo o dimensión de la realidad que sea puramente a priori, nouménico. Solamente Habermas habla de un mundo extraño en el que existen unos "intereses emancipatorios"; pero como no puede sostener que son puramente empíricos e históricos (pues quedarían a merced del consenso histórico, siempre fuente posible de prepotencia), pero tampoco puede mantener que son trascendentales (esto supondría volver al homo noumenon kantiano, con lo que ello implica de idealismo), indica que son "cuastrascendentales" ¡No ha sido un alarde de imaginación!

17 En la Crítica de razón pura, A 318, escribe que "Si prescindimos de la exageración de sus términos, el empeño espiritual de Platón [...] constituye un esfuerzo digno de ser respetado y proseguirlo. Un mérito muy especial de Platón se halla en lo relativo a los principios de la Moral, de la legislación y de la religión, donde son las ideas las que hacen posible la misma experiencia". Cfr. op. cit., p. 313. 
Este obra forma parte del acervo de la Biblioteca Jurídica Virtual del Instituto de Investigaciones Jurídicas de la UNAM www.juridicas.unam.mx

6. Estamos en un momento singularmente sincrético porque es preciso, entre otras cosas, hermanar la función socializante del lenguaje (que funciona ahora como sustituyendo el universo nouménico kantiano), con una pluralidad de individuos egoístas que buscan hacer realidad sus propios intereses. Sería una nueva clave de la filosofía kantiana: una dimensión de la realidad a priori (el lenguaje) que ha de hacer realidad a unos sujetos que son entendidos exclusivamente al modo de la juristische Person de los kantianos. ${ }^{18}$ La libertad de los individuos como única realidad práctica vuelve por sus fueros; sólo que esta vez tiene en cuenta también los intereses individuales: el hermanamiento entre el talante de Bentham y el de Kant es la figura estelar de nuestros nuevos sistemas de ética.

7. Ha quedado una herencia claramente fijada: las nuevas propuestas han de ser ellas mismas motores inmóviles, autosubsistentes. Ha fracasado académicamente el causalismo finalista aristotélico y el sujeto nouménico kantiano. Pero nos queda el lenguaje, que parece ser la patria común a todos los filósofos que no quieren hipotecarse con ningún homo noumenon.

8. Es lógico que hayamos perdido el mundo nouménico de Kant: el lenguaje no puede funcionar ya, según los esquemas mecánico-espaciales que advertimos en el pequeño prusiano. Aquellas inmensas superficies planas que tendían a expanderse hasta llenar todo el espacio amorfo no gozan hoy de prestigio. ${ }^{19}$ Ya no estamos en la edad del maquinismo, plagada de poleas, correas transmisoras, engranajes y todo tipo de ruedas dentadas. Definitivamente la mecánica ha perdido su fuerza inspiradora en nuestras facultades. Cosa lógica en la era de la informática. Nuestro lenguaje, la única patria común que admitimos tras Percey y Dewey, necesita otros muelles que le impriman movimiento emancipatorio.

9. Han vencido históricamente "Los kantianos", Die Kantianer, aquellos teóricos del derecho tocados por la filosofía crítica de Kant a finales del siglo XVIII y comienzos del siglo siguiente. ${ }^{20}$ Hoy se nos manifiesta en tono victorioso una idea omnipresente en los filósofos que dije-

18 Vid. mi estudio sobre la juristische Person, ya citado.

19 Es curioso que John Austin, en la primera mitad del siglo XIX, ya reparara en que "The writers would attend to the suggestions of Hobbes and Locke, and would imitate the method so successfully pursued by geometers [...]". Cfr. Lectures on Jurisprudence or the Philosophy of positive Law, London, 1911, $5^{\text {a }}$ ed. revisada y editada por R. Campbell, p. 137.

20 Estos epígonos del pensamiento práctico kantiano arrollaron los ambientes universitarios de Centroeuropa durante varios decenios. Para conocerlos, vid. mi estudio La cabeza de Jano, Universidad de Cádiz, 1988, en donde expongo las teorías de ellos. Un estudio anterior, parcialmente distinto, fue el de " 'Naturrecht' y 'Rechtsphilosophie"”, Anuario de Filosofía del Derecho, Madrid, nueva época, III, 1986, pp. 243-397. 
Este obra forma parte del acervo de la Biblioteca Jurídica Virtual del Instituto de Investigaciones Jurídicas de la UNAM www.juridicas.unam.mx

https://biblio.juridicas.unam.mx/bjv

ron seguir la filosofía de Kant: la exigencia de la igual libertad es el gran fundamento de "una sociedad bien ordenada", y las restantes exigencias del nóumeno han quedado marginadas.

El predominio de ideas socialistas durante buena parte de los siglos XIX y XX nos hizo creer que la función socializante del derecho desplazó a esta consideración del hecho jurídico: no ha sido así históricamente. Savigny introdujo concienzudamente en el derecho privado la visión del mundo humano como "esferas de libertad" individuales (Freiheitssph $\ddot{a}$ ren), ${ }^{21}$ y los tratadistas ingleses de Jurisprudence del siglo pasado nos informaban que ésta era la consideración del derecho dominante en Alemania aún en la segunda mitad del siglo. ${ }^{22}$

10. Me parece que esto ha sido así por exclusión: no convence el universo nouménico de Kant, que apareja demasiada mecánica y excesiva "fe filosófica", y es preferible dejarse llevar por las olas del pensamiento dominante. Pero este pensamiento se afinca en la misma medida que sus pérdidas: sólo le queda la igualdad de los sujetos, y se aferra a ella como el patrimonio indiscutido. La intersubjetividad del convencimiento de la igualdad individual hace innecesaria cualquier otro tipo de explicación. La igualdad no es, pues, un punto de llegada, sino el punto de partida indiscutible.

11. La individualidad, así entendida, posibilita el movimiento: la razón práctica ya puede marchar. La igualdad introduce el segundo momento de la eticidad, porque proporciona los fundamentos abstractos que corregirán las posibles desviaciones de la libertad que puedan degenerar en prepotencias. De hecho, no se trata tanto de la igual libertad, como de la igualdad.

12. Los kantianos se han impuesto otra vez a Kant. El maestro consideró a cada ser humano como portador de toda la idea de la humanidad,

21 Vid. Ligthwood, The Nature of Positive Law, London, 1883, p. 267. Aquí indica que "There are, however, strong reasons which make this view of Law inadmisible [...] As I before said, Savigny's System is a convenient on for the exposition of private Law, but is not sufficient for the explanation of Law as a whole". William Markby escribía, con más radicalidad, que "In this passage he speaks of private rights only, but I gather from the preceding page that he would apply the same principle to all law. Referring, I suppose, to Savigny's definition of a jural relation (Rechtsverhältniss) as a province of the independent mastery of the individual will'. Cfr. Elements of Law considered with reference to Principles of General Jurisprudence, $6^{\mathrm{a}}$ ed. Oxford, 1871, 55, p. 55, nota al pie. El énfasis es de Markby.

22 John M. Lightwood, en un estudio extenso de las diferencias de la "Philosophy of Law" alemana e inglesa, indicaba que la gran fisura entre una y otra estaba en que "German Jurisprudence, on the other hand, start from the idea that Law exits only to ensure the due liberty to the individual". Cfr. The Nature of Positive Law, cit., p. 260. 
Este obra forma parte del acervo de la Biblioteca Jurídica Virtual del Instituto de Investigaciones Jurídicas de la UNAM www.juridicas.unam.mx

por lo que jamás un hombre podría ponerse al servicio de los fines arbitrarios de otro: cada ser humano es un fin en sí mismo, un Selbstzweck.

Pero no se limitó a postular o deducir las "esferas de libertad" iguales (Freiheitssphären) como el único hilo conductor de la racionalidad práctica. El mundo moral "ya estaba dado", igual que el cielo estrellado encima de su cabeza. Y los motores de esa racionalidad (él los llamó los intereses de la razón) eran tres: la inmortalidad del alma, la existencia del Dios y la existencia de un orden moral objetivo. ${ }^{23}$

13. Es muy duro para el secularizado siglo XX, admitir estos intereses de la razón. Por esto, siguiendo a los kantianos en lugar de Kant, nuestro momento histórico postula la igualdad personal como "el interés de la razón" que posibilita hablar de la justicia.

La referencia a la igualdad personal no implica tratar a los seres humanos como personas, en el sentido que han dado a esta palabra las filosofías "personalistas". Seguimos más bien la versión estrecha de la juristische Person de los kantianos (que es también la del propio Kant en algunos momentos), es decir, unos seres de naturaleza individual que poseen una tendencia a expansionar esta individualidad a través de voluntad. Determinar si esa expansión de la voluntad se reduce a la defensa de sus esferas de libertad, o si tienen un contenido más amplio, supone tratar del tránsito de la filosofía liberal de comienzos del siglo XIX al Estado social de derecho actual.

Nuestro Estado social de derecho, ¿puede mantenerse desde los moldes teóricos que heredó? No, desde luego. Pero el sonar (klingeln) de la palabra "libertad" sigue siendo imprescindible en la práctica política, ${ }^{24} \mathrm{y}$ desde ahí ha saltado a nuestros estudios filosófico-jurídicos, que ahora quieren hacer una filosofía jurídica realmente encarnada en la vida social que vivimos. Ya pasó el tiempo de las teorías como las de Ahrens, Stammler, etcétera. El "realismo académico" es hoy imprescindible, si es que el universitario aspira a ser oído. Este nuevo realismo ha encontrado una presentación imponente en el análisis económico del derecho, que cabalmente es tan teórico como cualquier otra explicación doctrinal-acadé-

23 Aunque estos tres temas están omnipresentes en toda la tercera parte de la Crítica de la razón pura, es difícil encontrar una alusión unitaria a ellos. Al final de esta obra, en la "Sección III: La opinión, el saber y la creencia", hace una breve referencia a ellos en A 831, p. 645.

24 El barón D’Holbach ya denunciaba que "Les hommes, presque toujours gouvernés par des mots [...]”. Cfr. La Morale ..., cit., libro II, p. 52. 
Este obra forma parte del acervo de la Biblioteca Jurídica Virtual del Instituto de Investigaciones Jurídicas de la UNAM www.juridicas.unam.mx

https://biblio.juridicas.unam.mx/bjv

mica: pero todo lo que participe del "sonar" de la palabra "economía" se impone a nuestro espíritu.

14. La gran cuestión permanece: ¿cómo encontrar un nuevo procedimiento de hacer justicia que supere la simple expansión de la voluntad individual? Porque tras 1945 todos captan que las voluntades sumadas de los individuos pueden degenerar en prepotencia. ${ }^{25}$ Ya no sirve decir que "si puede equivocarse una mayoría, con mayor razón puede equivocarse una minoría", porque todos saben que la mayoría jamás se equivoca, sino que siempre —indefectiblemente - persigue sus propios intereses. Se ha hecho preciso abandonar la filosofía del derecho de estilo democrático y sustituirla por una teoría de la racionalidad práctica en la que una sola razón especialmente crítica determinará la verdadera verdad.

\section{KANT TUVO SUS PROPIAS IDEAS}

15. Nuestros kantianos actuales (introduzco en el saco de los kantianos toda la filosofía moral-jurídica triunfante del siglo XX) quieren cohonestar la inteligencia vulgar de la "razón práctica" del maestro con sus ideas. Porque desde la Modernidad hasta hoy, tras la crítica de HobbesPufendorf a la atrevida e impúdica "naturaleza de las cosas" que propugnaron Gabriel Vázquez, Luis de Molina, Francisco Suárez y Hugo Grocio, los adjetivos "bueno-malo" no pueden recaer directamente sobre una conducta humana. Descartadas las evidencias, se hizo necesaria la presencia de un "sistema de ética" que se interpusiera entre el hombre y sus actos para poder calificar éticamente una conducta. Esta me parece que ha sido una de las herencias fundamentales que nos ha dejado la Ilustración. La Modernidad prescindió de la conciencia moral intuitiva y, por ello, de los juicios directos sobre la moralidad.

Afortunadamente, los autores de los códigos penales que aparecieron en el siglo XIX dejaron de lado esta exigencia. Hubiera sido horrible que

25 Desde la Edad Moderna se impuso la tesis de "Utile, id quod libet", con lo que la utilidad se abrió a cualquier contenido. Aún Bentham participaba completamente de esta tesis, y nos proponía su anécdota del oculista: "On occasions like this, the legislator should never lose sight of the weelknow story of the oculist and the sot. A countryman who had hurt his eyes by drinking, went to a celebrated oculist for advice. He found him a table, wit a glass of wine before him. 'You must leave off drinking', said the oculist. 'How so', says the countryman? 'You don't, and yet methinks your own eyes are none of the best'. 'That's very true', replied the oculist: 'but you are know, I love my bottle better than my eyes"'. Cfr. An Introduction to the Principles of Morals and Legislation, London, 1823 cit., vol. II, chap. XVII, XV, p. 249, nota a pie. 
Este obra forma parte del acervo de la Biblioteca Jurídica Virtual del Instituto de Investigaciones Jurídicas de la UNAM www.juridicas.unam.mx

https://biblio.juridicas.unam.mx/bjv

quedaran sin castigar las falsificaciones, las violaciones, etcétera, hasta que el legislador hubiera encontrado un "sistema de ética" satisfactorio. Además, es de suponer que de una forma u otra siempre estuvo presente el reproche que lord Kames dirigió a las éticas ilustradas: demasiado abstractas y demasiado sublimes para mover a los hombres. ${ }^{26}$

Creo que llevaba más sentido de la realidad Adam Smith cuando indicaba que nos movemos por sentimientos no argumentables y que el cálculo de la utilidad es una ocurrencia posterior. ${ }^{27}$ Lorimer, no sin ironía, observaba que, de seguir estas éticas para obrar correctamente llegaríamos a un Law of parsimony. ${ }^{28}$ Y sucede que estas personas que están más preocupadas por el rigor racional que no por la razón, construyen artilugios extraños a los seres humanos y a su razón. ${ }^{29}$

16. El postulado de "la generalidad propia del imperativo categórico kantiano" parece responder a una constante psicológica humana: siempre ha existido la tesis que mantiene que las normas han de procurar un interés general: basta leer a Platón y Aristóteles para comprobar hasta qué punto (cada cual a su modo) esta exigencia ha estado presente en nuestra cultura. Esta idea la expresaron muchos pensadores mediante la doctrina del "bien común", hasta que esta doctrina misma quedó desprestigiada en la crítica que hicieron los ilustrados al pensamiento eudemonista del siglo XVIII. ${ }^{30}$ Entonces la figura de este bien se manifestó como un instrumento al servicio de cualquier despotismo. ${ }^{31}$

26 "He founds justice on a general sense of common interest (parece que se refiere a Hume and yet, at no greater distance than a few pages, he endeavours to make out (vol. 3, p. 43), and does it succesfuly, that public interest is a motive too remote and too sublime to affect the generality of mankind, and to operate, with any force, in actions so contrary to private interest". Cfr. Essays.., cit., p. 83.

27 "Originally, however, we approve of another man's judgement, not as something useful, but as right, as accurate, as agreable to true and reality: and it is evident we attribute those qualities to it for no other reason but because we find that it agrees with our own [...] The idea of utility of all qualities of this kind, is plainly an after-thought, and not firts recommends them to our approbation". Cfr. The Theory of Moral Sentiments, Oxford, Clarendon Press, 1979, p. 20.

28 Se refiere al imperativo categórico de Kant y escribe que "that it is too far complicated a matter for consciousness to reveal by any single act, and ennunciating it, Kant sinned against Sir William Hamilton's Law of Parsimony as egregiously as the Scottisch moralist in general haven sinned against his law of integrity". Cfr. The Institutes of Law, cit., p. 193.

29 Marin Mersenne, que ante todo reivindicó la razón frente a los racionalismos, escribía que "se trompent lourdement, et font de iugements qui tienent plus de preoccupation que de raison". Cfr. Questions harmoniques, Paris, 1634, pp. 224-225.

30 Vid. mi estudio La cabeza de Jano, cit., pp. 172-175.

31 Vid. John Austin, en las pp. 157-159 del vol. I de sus Lectures.., cit. 
Este obra forma parte del acervo de la Biblioteca Jurídica Virtual del Instituto de Investigaciones Jurídicas de la UNAM www.juridicas.unam.mx

https://biblio.juridicas.unam.mx/bjv

La crítica a la universalidad que expresó la tesis del "bien común" tuvo un gran oponente: el Estado liberal, teorizado ante todo por Locke, que situó el respeto (die Enthaltung, ${ }^{32}$ según los alemanes que extendieron esta doctrina) a la libertad, igualdad y propiedades ya adquiridas, como únicos fines posibles de todo Estado. Frente a la utilidad comunitaria situaron la utilidad individual o personal.

17. Parece que aquí andan revueltos dos temas: uno, el de la diferencia entre los bienes universales y los simplemente generales, que es la cisura que separa a la doctrina antigua del bien común de la inteligencia usual de las virtualidades del "imperativo categórico kantiano". El otro, la explicación filosófica de Kant, que fue diferente de la de sus discípulos, y que también es distinta de las actuales generalizaciones pretendidamente à la Kant.

18. Kant no contempló generalizaciones, no al menos en el sentido que damos ahora a esta expresión. Él creyó en una dinámica de la razón pura (que sólo existe cuando funciona) movida por los intereses de la razón, ya aludidos. Pero los motores intermedios, o aquellas palancas que permitían avanzar sus razonamientos hacia aquellas metas lejanas, eran el horror vacui y las leyes fundamentales de la mecánica de su tiempo. Con esto ha de contar quien quiera aplicar a Kant a los tiempos presentes. Si no pasa por este aro, el estudioso tendrá que irse a las trincheras de Bentham, si es que quiere seguir considerando utilidades.

Un tema espinoso, porque precisamente Kant intentó oponerse a los excesos del utilitarismo inglés. Por ello recabó tan fuertemente la autonomía moral frente a los sistemas productivos de felicidad de franceses y en mayor medida, porque entonces eran más conocidos, de los ingleses.

19. La ética kantiana no fue una ética de consecuencias o utilitarista. Las consecuencias de las acciones humanas están omnipresentes en Kant, pero no como fundamentadoras de la moralidad de los actos, sino como test de la posibilidad (¿cómo llamarla?) ontológica de cada acción: de su posibilidad nouménica.

20. La regla de oro kantiana es postular que es necesario todo aquello que no encierra contradicción en sí mismo. ${ }^{33}$ El adjetivo y adverbio omni-

32 Sobre esta abstención genérica en los alemanes en los tiempos que median entre la Ilustración y el Romanticismo, vid. mi estudio La cabeza de Jano, cit., pp. 175-182.

33 "Nada nos impide asumir esas ideas como objetivas e hipostáticas [...] En efecto, no habiendo en ellas contradicción, ¿cómo puede discutirse su realidad, teniendo en cuenta que el que lo haga sabe tan poco para negar la posibilidad de las mismas como sabemos nosotros para afirmarla?". Cfr. Crítica de la razón pura, cit., A 673, p. 549. 
Este obra forma parte del acervo de la Biblioteca Jurídica Virtual del Instituto de Investigaciones Jurídicas de la UNAM www.juridicas.unam.mx

https://biblio.juridicas.unam.mx/bjv

presente en la explicación kantiana es el de nothwendig (transcrito en el alemán de aquella época), que significa indistintamente necesario y necesariamente. Tal vez yo no diría que es necesario todo lo que no encuentra contradicción consigo mismo; pero Kant se adueñó en este punto de la terminología propia de las defensas de las tesis doctorales y explicó reiteradamente que "melior est condictio possidentis". ${ }^{34}$ Luego, el que quiera impugnar que esto es así ha de demostrar ("deducir") expresamente su falsedad. Empresa imposible, como Kant sabía: una zorrería de un filósofo experimentado.

21. Mediante el examen de las consecuencias de un acto sabemos si es posible racionalmente (nouménicamente) esa acción. Porque si las consecuencias que se derivan necesariamente de la generalización de las consecuencias de una acción llevan a negar en sí misma la posibilidad de esta acción, entonces tal acto no se sostiene. ${ }^{35}$ El único ejemplo que proporcionó Kant fue el del mentiroso. La mentira es imposible, o no tiene consistencia nouménica, porque el mentiroso pretende encontrar fe en los demás. Pero si el que miente universaliza su acción, y supone que a todos les es lícito (dürfen) mentir, nadie encontraría fe en los demás, y el que miente anularía así aquello que él pretende crear en los demás. Luego la acción se anula en sí misma.

Observemos que las consecuencias no califican "moralmente" a un acto, sino que constituyen a cada acto en necesario o imposible. Si la universalización de las consecuencias "calificara moralmente" a las acciones estaríamos otra vez ante la realidad de la vieja conciencia moral, o ante el "Principle of utility". Dos posibilidades que Kant no quiso tener en cuenta.

El imperativo categórico, la universalización que le es inherente, consistía en elevar el "móvil" subjetivo de la acción (Triebfeder) a ley (Gesetz), que es necesariamente universal. ${ }^{36}$ Así filtraba el provecho pretendido por el hombre individual por el filtro del propio Nóumeno, de modo

34 "Es, por tanto, el adversario el que tiene que presentar pruebas. Pero como éste, a la hora de demostrar el no-ser del objeto puesto en duda, sabe tan poco como el que afirma su realidad, queda evidente la ventaja del que sostiene algo como supuesto necesario desde un punto de vista práctico (melior est condictio possidentis)". Cfr. Crítica de la razón pura, cit., A 777, p. 613.

35 Una declaración prácticamente programática la encontramos en la Crítica de la razón pura: "se trata [...] de derivar un estado de su causa o de derivar la existencia contingente de la substancia misma de la existencia necesaria". Cfr. op. cit., A 560. En A 562 reitera: "limitar también la ley del uso meramente empírico del entendimiento de modo que no decida sobre la posibilidad de las cosas en general".

36 Vid., por ejemplo, Principios metafísicos de la doctrina del derecho, cit., p. 17. 
Este obra forma parte del acervo de la Biblioteca Jurídica Virtual del Instituto de Investigaciones Jurídicas de la UNAM www.juridicas.unam.mx

https://biblio.juridicas.unam.mx/bjv

que podríamos acceder a un plano de la realidad que no podríamos conocer desde los datos simplemente naturales y contingentes. Este elevar el Triebfeder a Gesetz (el móvil a "ley", siempre universal), suponía insertar a cada ser humano en el campo de los fines superiores de la razón. Se trataba de una operación estrictamente racional, inteligible o nouménica, muy ajena a pretensiones moralizantes. ${ }^{37}$

¿Quién ha de realizar esta universalización? Cualquier persona humana que haga funcionar su razón correctamente está habilitada para universalizar sus móviles. Porque la razón es común a todos, y una vez que nos introducimos en su terreno, poco importa quién la conozca. ${ }^{38}$ En modo alguno —-sostiene Kant expresamente- existiría una casta de hombres (los filósofos) que poseyera una razón de mayor calidad que las personas corrientes. ${ }^{39}$ Con estas declaraciones pretendía algo más que destacar la objetividad de la razón, común a todos los hombres: quería oponerse a los teóricos del despotismo monárquico del siglo XVIII que, de la mano de Christian Thomasius, habían dividido a los hombres en dos clases: los inteligentes (sapientes), que constituyen una minoría, y los necios (stulti), que ni siquiera saben lo que les conviene. ${ }^{40}$

22. Manifestaba un cierto talante griego: solamente existe lo que es necesario o racional, y todo lo que existe es vinculante o genera un deber. Cabalmente, no aparece claro en su explicación de la moralidad el tránsito desde el plano de la realidad al plano del deber, que supone generado por el hecho de ser necesariamente.

Tengamos cuidado con la fuerza de las palabras: él no trata del paso desde el is al ought, al que aludió Hume. Él zanjó a su modo esta cuestión, asumiendo la crítica de Hume en su escueta "estética trascendental". Pero su "fe filosófica" le llevó a un planteamiento distinto de la cuestión, que fue el que realizó en la tercera parte de la Crítica de la razón pura. Lo que ahora pongo sobre el tapete es si la peculiar virtualidad del imperativo categórico, que es la de mostrarnos lo que necesariamente

37 Una exposición más extensa de esta inteligencia de Kant, la puede encontrar el lector en mi estudio “Las canas de Kant”, en Anuario de Filosofía del Derecho, Madrid, XI, 1994, pp. 443-466.

38 En sus Principios metafísicos de la doctrina del derecho, ed, cit., p. 22, explicaba que "El imperativo es una regla práctica en virtud de la cual una acción en sí misma contingente se convierte en necesaria [...] El imperativo es, pues, una regla cuya representación hace necesaria la acción subjetivamente contingente, y representa al sujeto en el deber de ponerse necesariamente en armonía con esa regla [...] por la simple representación de esa acción misma (de su forma)". El énfasis es de Kant.

39 Vid. su Crítica de la razón pura, cit., A 831, p. 646.

40 Vid., por ejemplo, su Fundamenta iuris naturae et gentium ex sensu communi deducta, Halae et Lipsiae, 1718, 1. I, cap. III por entero. 
Este obra forma parte del acervo de la Biblioteca Jurídica Virtual del Instituto de Investigaciones Jurídicas de la UNAM www.juridicas.unam.mx

ha de existir en el mundo nouménico o racional, determina normativamente la conducta del hombre. Parece que es así, porque entiende que "el <conocimiento> teórico es aquel en virtud del cual conozco lo que es; el práctico es aquel en virtud el cual conozco lo que debe ser". ${ }^{41} \mathrm{El}$ uso trascendental de la razón, al que está dedicada la tercera parte de la Crítica de la razón pura, constituye, sin más, el conocimiento práctico. El tránsito del ser al deber ser está resuelto analíticamente, porque la razón posee la capacidad de crear el deber: "Que esta razón posee causalidad, o que al menos nos representamos que la posee, es algo que queda claro en virtud de los imperativos que en todo lo práctico proponemos como reglas a las facultades activas. El deber expresa un tipo de necesidad y de relación con fundamentos que no aparece en ninguna otra parte de la naturaleza". ${ }^{42}$

23. Hablar de la "generalización propia del imperativo categórico kantiano", tal como es entendida usualmente, poco tiene que ver con la explicación que Kant proporcionó sobre la realidad práctica humana. Desde luego, querer compatibilizar la generalización de cuño benthamiano con el imperativo categórico kantiano plantea muchos más problemas teóricos que dificultades resuelve académicamente.

\section{LA SEPARACIÓN DEL DERECHO Y LA MORAL}

24. Frente a las consecuencias deshumanizantes de los utilitarismos ingleses, Kant enunció una regla fundamental de su moral: "no ser medio al servicio de los fines arbitrarios (willkürhlich) de otros". Esta exigencia se fundamentaba en última instancia en su exigencia de autonomía moral: cada hombre había él personalmente de asumir el mundo moral, ya constituido, de forma que obrara solamente por respeto a la misma norma moral (aus Achtung), no por otras consideraciones. La heteronomía provenía de obrar por una "afección patológica", como son todas las que provienen de la sensualidad. ${ }^{43}$ Nunca en la historia de la ética se ha lanzado una exigencia tan fuerte. Kant trataba de oponerse a la noción de libertad como simple arbitrio, que por aquellos años estaba dominando la escena

41 Crítica de la razón pura, cit., A 633, p. 525.

42 Crítica de la razón pura, cit., A 547, p. 472.

43 En A 802, p. 628 de la edición citada de la Crítica de la razón pura, distingue el "arbitrium brutum", afectado empíricamente, del "arbitrium liberum", cuyo Befolgungsmodus son sólo las "representaciones de la razón". 
Este obra forma parte del acervo de la Biblioteca Jurídica Virtual del Instituto de Investigaciones Jurídicas de la UNAM www.juridicas.unam.mx

https://biblio.juridicas.unam.mx/bjv

universitaria de la mano de los calvinistas de Escocia y de diversos profesores suizos. ${ }^{44}$ La libertad consistiría — según el de Könisberg-, en la cualidad que recae sobre todo ser humano porque él ha de asumir personalmente el mundo moral ya existente. ${ }^{45}$ De este modo, la heteronomía que acarrea la existencia de normas no creadas por el sujeto que ha de obedecerlas quedaría sustituida por la autonomía que resultaba del aceptamiento voluntario y personal de esas normas: obedecer es, en Kant, ante todo un acto de la propia voluntad, que obedece con buena fe, esto es, por respeto a la norma misma, no por otras ventajas que pudieran resultarle al obediente de la obediencia a las normas. A veces leemos en autores alemanes que el hombre posee dignidad porque él ha de realizar un plan moral "personal". El adjetivo personal tiene una función muy distinta en Kant y en estos otros, que parecen entender que la autonomía sería ese tipo de causalidad que Kant llamaba "arbitraria" o "bruta", arbitrium brutum, que siempre tiene la posibilidad de apartarse del cumplimiento de la ley moral. ${ }^{46}$

25. Esta exigencia de autonomía tuvo un rebote importante. La moral poseía su propia "forma de ser seguida", su Befolgungsmodus, que era el obrar aus Achtung ante las normas morales, excluyendo las afecciones que provienen del mundo no nouménico, esto es, del mundo exterior o de los sentidos, el Sinnenwelt. Pero el derecho pertenece al este mundo exterior o Sinnenwelt. Esto requiere de una observación.

El ámbito de la moralidad es, según Kant, el de lo necesario. Éste no es el caso del derecho, que no es necesario, sino contingente, porque varía

44 Lord Kames dedicó el Essay III a estudiar en qué consiste la libertad humana. De un lado, ésta era negada ya francamente por los autores materialistas, y de otro, los calvinistas y arminianos la estaban dejando reducida a espontaneidad o arbitrium merae indifferentiae. Un resumen del estado de esta cuestión lo tenemos en las pp. 165-179 de la obra citada.

45 Kant distinguía entre la personalidad moral y la personalidad psicológica. La libertad es una cualidad de aquélla, no de ésta: "Una persona es el sujeto cuyas acciones son susceptibles de imputación. La personalidad moral no es más que la libertad de un ser racional sometido a las leyes morales. La personalidad psicológica no es más que la facultad del ser que tienen conciencia de sí mismo en los diferentes estados de la identidad de su existencia. De donde se sigue que una persona no puede ser sometida más que a las leyes que ella misma se da, ya a sí sola ya al mismo tiempo que a otros". Cfr. Principios metafísicos de la doctrina del derecho, cit., p. 24.

46 El de Könisberg poseía mal concepto de las inclinaciones del hombre, y escribía que "no conocemos la libertad (tal como la ley moral nos la revela por primera vez), más que como una cualidad negativa, que significa la ausencia de principios sensibles de determinación que produzcan en nosotros la necesidad de la acción. Pero como nóumenos, es decir, considerados relativamente a la facultad del hombre en cuanto simple inteligencia". Cfr. Principios metafísicos de la doctrina del derecho, cit., p. 27. El énfasis es de Kant. 
Este obra forma parte del acervo de la Biblioteca Jurídica Virtual del Instituto de Investigaciones Jurídicas de la UNAM www.juridicas.unam.mx

https://biblio.juridicas.unam.mx/bjv

de tiempo en tiempo y de lugar en lugar: luego el derecho coexiste al margen de la moral.

Pero existía un segundo motivo quizá más decisivo para separar el derecho y la moral: ésta había de ser seguida "por respeto" a sus normas, y el derecho necesitaba (necesariamente) de la coacción (Zwang): la moral y el derecho quedaban tan separados como lo estaban la autonomía moral y el comportamiento determinado por la sanción externa coercitiva. ${ }^{47}$ Kant analizó las relaciones entre derecho y moral indistintamente, tanto desde su inicio como desde su final: no se remontó exclusivamente a las fuentes, sino también al distinto Befolgungsmodus para ser cumplidas sus respectivas normas. Y a esta "forma de seguimiento" la erigió en fuente discriminadora de lo que era moral o jurídico. Pero al proceder así, situando la moral exclusivamente en el mundo de la autonomía personal, expulsaba al derecho del mundo ético. Hegel se quejaba de este hecho: "El lenguaje kantiano usa con preferencia la expresión 'moralidad', y en realidad los principios prácticos de su filosofía se limitan completamente a este concepto y hacen imposible el punto de vista de 'eticidad', a la que incluso ataca y aniquila expresamente". ${ }^{48}$ En otras palabras, como denunció Gerhard Dulckeit hace años, la metafísica del derecho kantiana no era capaz de dar cuenta de la moralidad o justicia del derecho existente. ${ }^{49}$

47 Kant fue muy rotundo en ocasiones al tratar este tema. En Los principios metafísicos de la doctrina del derecho, cit., p. 34, explicaba que "El derecho estricto es aquel en el que no se mezcla nada propio de la moral, el que no exige más que principios exteriores de determinación para el arbitrio; porque en este caso es puro y sin mezcla de precepto moral alguno". La exigencia objetiva que daría lugar a la posibilidad del convencimiento, quedó expresamente excluida: "Así pues, cuando se dice: un acreedor tiene el derecho de exigir a su deudor el pago de su deuda, no se quiere decir que pueda persuadirle a que su propia razón le obligue a esta devolución, sino que el forzarle a esta devolución, fuerza que se extiende a todos, puede subsistir con la libertad general". Cfr. ibidem. Como podemos observar, el único principio metafísico y sustantivo (moral) del derecho es la exigencia de la posibilidad de coordinar las iguales libertades. En todo momento está presente la definición del derecho que él proporcionó en esta misma obra, p. 32: "Es justa toda acción que por sí, o por su máxima, no es obstáculo a la conformidad de la libertad del arbitrio de todos con la libertad de cada uno según leyes universales".

48 Principios de la filosofía del derecho..., cit., p. 33.

49 Vid. Naturrecht und positives Recht bei Kant, Leipzig, 1932. Existe reproducción más reciente de la editorial Scientia, de Aalen. La actitud de Kant fue cautelosa y vacilante en el tratamiento de este problema, y llegaba a escribir, en cierta contradicción con lo anterior, que "La moral enseña solamente sobre este punto que, si el motivo que en la legislación positiva va unido a cada deber, es decir, si la coacción externa faltase, la idea del deber debe ser por sí sola un motivo suficiente [...] La ciencia del derecho y la de la moral difieren, pues, mucho menos por la diferencia misma de los deberes que le son propios, que por la diversidad del motivo que una y otra legislación consignan en la ley". Cfr. Principios metafísicos de la doctrina del derecho, cit., p. 19. 
Este obra forma parte del acervo de la Biblioteca Jurídica Virtual del Instituto de Investigaciones Jurídicas de la UNAM www.juridicas.unam.mx

https://biblio.juridicas.unam.mx/bjv

26. Siempre podemos pensar que Kant sí diseñó una "moralidad del derecho", la que expuso en su Metaphysik des Rechtes. Pero las virtualidades de esta metafísica se limitaron a la exigencia de respeto (Enthaltung) ante los derechos fundamentales (Urrechte) de los demás y no podían dar cuenta del derecho que no fuera estrictamente derecho penal. ${ }^{50}$ Estos derechos eran tres: libertad, igualdad y propiedades, que peligraban en el "estado de naturaleza" (que era un estado vacío de justicia status justitiae vacuus). ${ }^{51}$ Ante esta realidad, la razón demandaba que el individuo se trasladase desde este estado de naturaleza a un estado de justicia.

27. Y tarde o temprano se nos manifiesta un tema realmente crucial: ¿es posible trasplantar las exigencias morales de la universalización a través de las consecuencias, al mundo jurídico? Dicho brutalmente: esta necesidad de universalización, ¿ha de quedar restringida necesariamente al terreno de la moral, o puede y debe ser ampliada al derecho?

28. El pensador prusiano fue más preciso de lo que aparenta: en él, el rigor es requisito filosófico ineludible. Porque siempre trazó una línea divisoria entre los mundos para él infranqueables de lo necesario (nothwendig) y de lo contingente o arbitrario (willkührlich). La moral ha de ser siempre universal, es decir, necesaria. El derecho, por contra, vive en el campo de lo contingente. La única exigencia universal dirigida al mundo jurídico es la derivación práctica del Selbstzweck que expuso en su "metafísica del derecho".

En este momento de su filosofía mostró un singular sentido de la realidad, quizá menos presente en la exigencia de universalidad moral. Porque todos sabemos que las determinaciones jurídicas raras veces son necesarias. El título de una revista de historia del pensamiento jurídico (Jus Fugit) expresa algo sabido: cada estilo ante la vida conlleva su derecho, y éste no expresa necesidad metafísica, sino conveniencia histórica. Una conveniencia que lo será para muchos, o para pocos, pero conveniencia, no necesidad normalmente. Consecuentemente, las normas jurídicas no

50 Thomas Erskine Holland denunciaba este problema de la "metafísica del derecho" de Kant: "This conception is purely negative, and a wider and positive conception is needed to embrace the operation of Public as well as of Private Law. The Kantian definition is wide enough to cover all rules which regulate the relations of individuals one to another, but it is too narrow to cover enactements providing, for instance, for the organisation of a ministry of education". Cfr. The Elements of Jurisprudence, $13^{\mathrm{a}}$ ed., Oxford, 1924, p. 80.

51 "Es por lo menos un estado de justicia negativa (status justitiae vacuus), en el cual, si el derecho fuera controvertido, no habría juez competente para dictar una sentencia legítima, en virtud de la cual cada uno pudiera obligar a otro a salir de ese estado de guerra y hacerle entrar en un estado jurídico". Cfr. Principios metafísicos de la doctrina del derecho, cit., p. 141. 
Este obra forma parte del acervo de la Biblioteca Jurídica Virtual del Instituto de Investigaciones Jurídicas de la UNAM www.juridicas.unam.mx

https://biblio.juridicas.unam.mx/bjv

pueden pretender esa capacidad de autoimposición que sí es propia del mundo moral, que es normativo, según Kant, porque es necesario. El derecho, por contra, no es necesario o universal. El adjetivo "universal" ha de reservarse —en el pensamiento de Kant — para la moral. Porque para él, el mundo humano está dividido por la barrera de la contingencia: el mundo exterior, sometido a las afecciones de la sensualidad, es contingente, y sus determinaciones serán siempre arbitrarias. El mundo nouménico es necesariamente universal. ${ }^{52}$

29. Me parece que hemos perdido el talante kantiano para la tolerancia, una tolerancia que si no existía en la moral, sí estaba presente en el derecho: porque algunos hablan de obtener una solución (simultáneamente moral y jurídica) que haya de ser obedecida necesariamente por todo ser racional. ${ }^{53}$

Según Kant hubiera supuesto una exigencia inhumana lanzar esta exigencia de universalidad al mundo del derecho. Además, es una ilusión, porque la mayor parte de las formas e instituciones jurídicas ni soportan ni requieren esta exigencia.

\section{IV. “UNA POSIBILIDAD SIEMPRE PRESENTE”}

30. Volvemos al tema planteado: a pesar de ser conscientes de habernos separado toto coelo de la propuesta kantiana para normar la realidad, ¿no sería posible hablar de la generalización kantiana de las utilidades como el criterio más fundante de la eticidad?

31. Esta regla ha estado presente siempre, de una forma u otra, en nuestros pensadores. Los teólogos y juristas de la Baja Edad Media aludían frecuentemente a lo que entonces llamaban la regla áurea o evangélica: "Trata a los demás como quieres que los demás te traten a ti". Formulada de una manera simplemente negativa sería: "No hagas a los

52 En la Crítica de la razón pura destaca la diferencia entre el funcionamiento trascendental de la razón, siempre en busca de lo que es necesario, y su oposición a lo contingente: "la existencia de los fenómenos, que no posee ningún fundamento propio, sino que es condicionada, nos invita a buscar algo distinto de todos los fenómenos, es decir, un objeto inteligible en el que cese tal contingencia". Cfr. op. cit., A 566, p. 484 de esta edición. Lo único necesario es la moral y la metafísica del derecho, que se deducen necesariamente desde las leyes de la razón pura. El derecho positivo, que es así pero podría ser de otra forma, es contingente, no susceptible de tratamiento filosófico.

53 Ésta era una pretensión típicamente moderna, porque la modernidad quiso universalizar la ética. Harrington la denunciaba escribiendo que "And if reason be nothing else but interest, and the interest of mankind be the right interest, then the reason of mankind must be right reason". Cfr. The Oceana.., cit., p. 43. 
Este obra forma parte del acervo de la Biblioteca Jurídica Virtual del Instituto de Investigaciones Jurídicas de la UNAM www.juridicas.unam.mx

https://biblio.juridicas.unam.mx/bjv

demás lo que no quieres que los demás hagan contigo". Esta última versión fue defendida por Anselmo de Canterbury, entre otros.

32. ¿Por qué no prosperaron en la jurisprudentia estas reglas tan generales? Sin perjuicio de sus beneficiosos efectos en la moral personal, parecen de escasa operatividad jurídica por su excesiva generalidad. Y tampoco parecen ser de grandes virtualidades morales, al menos para proponer una ética general, porque pocos pueden soportar la inhumanidad de ser tratados ellos como les parece a las otras personas que todos han de ser tratados. Pero, especialmente, no es convincente como fundamento de la moral por un par de razones que no se deducen tanto de la lógica de los conceptos universales como desde una observación de la praxis humana.

Ahora se nos presenta el problema que quedó planteado en el 17, a saber: la diferencia entre el procedimiento de universalización, que llevaba a obtener bienes universalmente válidos, y el procedimiento de la simple generalización, por el que únicamente obtendríamos bienes simplemente generales. Obviamente, los bienes sólo pueden ser universales; pero esto no implica que estos bienes así expuestos hayan de ser conductas "buenas en sí mismas", y de validez eterna.

33. Para abordar este tema, veamos la primera observación a la que aludía. No parece razonable proponer universalmente como ley moral solamente aquello que puede ser elevado a norma universal. La doctrina escolástica sobre los comportamientos contingentes (contingentia), que se refieren al obrar humano, más que al producir cosas (los comportamientos que producen cosas eran llamados agibilia), han de contar con modulaciones históricas y personales que escapan a la pretensión de universalidad. ${ }^{54}$ Por este motivo, el de Aquino escribía que "Debido a las condiciones distintas de los hombres, unas cosas son virtuosas para unos, como adecuadas y proporcionadas para ellos, y esas mismas cosas son viciosas para otros, por desproporcionadas". 55

54 Tomás de Aquino consideró que el "medio" que hay que calcular en la moral es un medio relativo a cada persona concreta, y por esto lo llamó medium rationis, para diferenciarlo del medio del derecho que tiende a ser más igual para todos, al que llamó medium rei. de la mano de Aristóteles concedió gran importancia a esta personalización de la moral frente a la justicia, y dedicó todo un artículo de la Suma teológica a mostrar las razones por las que el derecho es tan real, tan distinto del resto de la moral, concretamente la. Vid. II-II, p. 58.

55 "Ad tertium dicendum quod ratio illa procedit de actibus secundum seipsos consideratis. Sic enim, propter diversas hominum conditiones, contigit quod aliqui actus sunt aliquibus virtuosi, tanquam eis proportionati et convenientes, qui tamen sunt aliis vitiosi, tanquam eis non proportionati”. Cfr. Suma teológica, I-II, q. 94, art. 4. Abundando en esta tesis, en la Suma teológica, II-II, p. 49, art. 
Este obra forma parte del acervo de la Biblioteca Jurídica Virtual del Instituto de Investigaciones Jurídicas de la UNAM www.juridicas.unam.mx

Pero esta explicación de Tomás de Aquino, ¿no supone rehacer la historia del pensamiento jurídico y ético para acomodar viejas doctrinas a los tiempos que corren? Porque aún hoy lanzamos sobre la antigüedad los juicios que expresaba Joseph Glanvill en el siglo XVII. ${ }^{56}$ Y, además, porque según la inteligencia usual de la historia, Tomás habría mantenido que las cosas son buenas o malas "en sí mismas”. Gabriel Vázquez, Luis de Molina y Francisco Suárez sí explicaron —muy expresamente contra la explicación prudencial de la jurisprudentia propia de Tomásque "la naturaleza de las cosas" determina por sí sola su bondad o malicia. Para hacer posible esta explicación aludieron a las cosas in se ipsas, seclusis aliis circunstantiis, consideradas formaliter, expresándonos proprie loquendo, etcétera. Desarrollaron una fraseología impresionante - especialmente Suárez- para negar lo que era evidente. Hugo Grocio, desde luego, picó su anzuelo.

Así, tenemos una versión piadosa de la historia: primero habrían propuesto la buena doctrina, que sólo posteriormente habría resultado desfigurada en manos incapaces o malvadas. Lamento seguir el camino aparente de las explicaciones piadosas. Sucede únicamente que esta vez sí fue verdad.

34. La otra razón, porque esta universalidad desdibuja o destiñe la vertiente realmente decisiva de la moral, que es esa faceta intransitiva de la acción humana que los griegos designaron como praxis. Porque la moral no es ante todo un procedimiento para conocer normas necesarias en sí, como pretendía Kant y siguen pretendiendo los tratadistas actuales de ética que quieren superar las deficiencias del talante de Bentham. Por contra, entender que la dimensión propiamente humana de nuestros actos es la práctica (que es tan poco dada a universalidades como a personalismos fáciles), fue patrimonio indiscutido de la mentalidad premoderna. ${ }^{57}$

7, escribía que "Sed quia prudentia est circa singularia operabilia, in quibus multa concurrunt, contingit aliquid secundum se consideratum esse bonum et conveniens fini, quod tamen ex aliquibus concurrentibus redditur vel malum vel non oportunum ad finem".

56 "And there is nothing hath stincted its Growth, and hindred its Improvements more, than an over-fond, superstitious Opinions of Aristotle, and Ancients, by which it is presumed that their books are the 'Nec-Ultra' of Learning, and that little or nothing can be added to their discoveries". Cfr. Essays on Several Importants Subjects in Philosophy and Religion, London, 1675, Essay II, p. 1.

57 Tomás de Aquino escribía que "Est enim duplex genus operationum animae. Quarum quaedam transeunt in exteriorem materiam, sicut texere et aedificare. Et huismodi operationes non sunt fines, sed operata ipsorum, scilicet contextus [...] Quaedam vero operationes animae sunt in ipso operante manentes, sicut intelligere et velle. Et huiusmodi operationes sunt fines. Recte ergo dictum est quod ipsi actus et operationes sunt fines, dum scilicet posuimus felicitatem esse operationem et non 
Este obra forma parte del acervo de la Biblioteca Jurídica Virtual del Instituto de Investigaciones Jurídicas de la UNAM www.juridicas.unam.mx

https://biblio.juridicas.unam.mx/bjv

Adam Ferguson reparó, en el siglo XVIII, en el desplazamiento de las vertientes prácticas de nuestras acciones en la mayor parte de los sistemas éticos de la modernidad, y se expresó sobre ello con claridad escolar:

Los mismos términos de "placer" y “dolor" son quizá equívocos, si se limitan, como aparecen en muchos de nuestros razonamientos, a las simples sensaciones que hacen referencia a los objetos externos [...] es un grave error suponer que dichos términos incluyen todos los componentes de la felicidad o de la desgracia [...] Preguntemos a las personas ocupadas: ¿dónde se encuentra la felicidad a la que aspiran?, y ellas contestarán que en lograr algún objetivo inmediato. Si les preguntamos por qué no se sienten desgraciados en la ausencia de esa felicidad, nos contestarán que ellos esperan lograrla. Pero, ¿es sólo la esperanza la que mantiene el ánimo [...]? Dad al cazador su pieza, al jugador el oro de su apuesta en el juego, de modo que no tenga necesidad de fatigarse, y ambos probablemente se reirán de vuestra locura. Uno volverá a apostar su dinero de nuevo, para cavilar nuevamente; el otro pondrá el ciervo en libertad [...] Despojad al hombre de sus ocupaciones, acabad sus deseos, y la existencia será una carga y la repetición de los recuerdos de un tormento. ${ }^{58}$

Efectivamente, la finalidad de nuestra actuación no puede estar fuera de ella misma. Lord Kames explicaba juiciosamente, desde un ángulo cristiano (en plena polémica por la secularización, en el siglo XVIII), que la virtud no puede consistir simplemente en cumplir la voluntad de Dios. ${ }^{59}$ Porque parecía evidente que la simple conformidad a otra voluntad (aunque fuera la divina), esperando una retribución, era más una cuestión de regateo (bargain) o de interés, que no de virtud. ${ }^{60}$

aliquid operatum. Sic enim felicitas ponitur aliquid bonorum quae sunt circa animam, et non aliquid eorum quae sunt exterius. Operatio enim manens in agente, ipsamet est perfectio et bonum agentis. In operibus autem quae procedunt exterius, perfectio est bonum in exterioribus effectibus invenitur". Cfr. In decem libros Ethicorum Aristotelis expositio, Roma, Marietti, 1964, p. 144.

58 Un ensayo sobre la historia de la sociedad civil, trad. de J. Rincón, Madrid, Instituto de Estudios Políticos, 1974 (primera edición de 1777), pp. 52-53.

59 "That morality depens entirely of the will of God, and that his will creates the only obligation we lie under to be virtuous, is the opinion of several writers. This opinion, in one sense, is true; but far from being true in their sense who inculcate it". Cfr. Essays.., cit., p. 68.

60 Lord Shaftesbury explicaba "For the stronger this affection is in any one, the less will be able to have true 'Resignation', or 'Submission' to the Rule and Order of the Deity. And if that which he calls 'Resignation' depends only on the expectation of infinite Retribution or Reward, he discovers no more Worth or Virtue here, than in any other Bargain or Interest". Cfr. "An Inquiry concerning Virtue and Merit", Characteristics of Men, Manners, Opinions, Times, 1711, vol. II, p. 59. 
Este obra forma parte del acervo de la Biblioteca Jurídica Virtual del Instituto de Investigaciones Jurídicas de la UNAM www.juridicas.unam.mx

https://biblio.juridicas.unam.mx/bjv

En este mismo sentido, Tomás de Aquino explicaba que "El acto de la virtud es más importante que la virtud misma". ${ }^{61}$ Criticó a fondo el ejemplo aristotélico del médico, porque Aristóteles había dejado escrito que el que busca la justicia ha de comportarse como el médico, que no busca la sanidad en abstracto, sino la salud de este paciente. Tomás le contesta que no es así, porque el que busca la justicia no ha de comportarse como el médico que quiere - como sea- la salud (el acto justo en este caso). Sino que el que quiere la justicia ha de comportarse como actúa el hombre que actúa virtuosamente, no produciendo sin más actos justos. ${ }^{62}$

El siglo XVIII se separó notablemente de esta forma de entender la realidad humana, porque Thomasius, Hume o Bentham buscaron un hedonismo. Thomasius explicó que "omnes homines volunt vivere foelicissime, et diuturne", y éste habría podido ser el lema de esta ética. Pero el desarrollo de la sociedad capitalista ha mostrado que éste no es el camino, y que la objeción que podemos hacer a la moral puritana (¿para qué tantas normas?) es traspasable al hedonismo ilustrado: ¿para qué vivir tanto tiempo y con tantas cosas? Parece que nuestra Ilustración olvidó la distinción griega entre praxis y poiesis, redescubierta por los medievales, que la llamaron agere-facere: unas categorías válidas mientras haya hombres.

Kant reaccionó con cierta violencia contra este eudemonismo ${ }^{63}$ moral que implementaba la humanidad al servicio de fines inferiores al hombre mismo. Pero se detuvo conscientemente en la buena voluntad del que cumple la norma por la norma misma. ¿Residuos de su formación puritana? Es posible. Pero tal vez quiso poner una puerta a cualquier eudemonismo posterior que contemplara a la moral como un instrumento para un fin ulterior. La norma por la norma es un programa escasamente convin-

61 "Unde operatio secundum virtutem est perfectior quam ipsa virtus". Cfr. In decem libros Ethicorum.., cit., 152.

62 "Et dicit se refiere a Aristóteles quod sapientia et prudentia faciunt quidem aliquid ad felicitatem. Sed exemplum quod inducebatur non erat conveniens. Non enim hoc modo se habent sapientia et prudentiam ad felicitatem, sicut ars medicinae ad sanitatem, sed magis sicut sanitas ad opera sana". Cfr. In decem libros Ethicorum.., cit., 1267. En el 1290 continúa: "Sed ars medicinae praecipit qualiter fiat sanitas, ita quod praecipit propter sanitatem, sed non sanitati. Et similiter prudentia, etiam politica, non utitur sapientia praecipiens illi qualiter debet iudicare circa res divisas, sed praecipit propter illam, ordinans scilicet qualiter homines possint ad sapientiam pervenire".

63 Cabalmente, la ética propia de la Ilustración no puede ser llamada eudemonista, sino hedonista: se trata de una cuestión de conveniencia en el uso de las palabras. La ética eudemonista más antigua, la que arranca del pensamiento griego, presupone los bienes externos al hombre, el dominium rerum externarum, pero su finalidad se sitúa bastante más allá de unos instintos o apetitos sensibles satisfechos. 
Este obra forma parte del acervo de la Biblioteca Jurídica Virtual del Instituto de Investigaciones Jurídicas de la UNAM www.juridicas.unam.mx

https://biblio.juridicas.unam.mx/bjv

cente para unos seres tan poco lógicos como los seres humanos. Quizá estuvo más cerca de la humanidad Anselmo de Canterbury cuando definió la justicia como la "rectitudo voluntatis propter se servata", porque situó el acento más en el hombre que no en la normas.

Llega un momento en el que la fuerza expresiva de las palabras usadas académicamente se nos muestra incapaz. Creo que fue Tomás el que mejor se expresó. En su critica a Aristóteles (pensemos otra vez en el ejemplo del médico) mostró que el hombre no puede situar las normas al margen de su vida misma, porque sería indigno de la vida humana ser juzgada desde unas instancias que no fueran esa misma vida. En los Comentarios a la ética y en la Segunda-segunda de la Suma teológica son numerosos los pasajes en los que afirma que la justicia (sin dejar de consistir en hacer lo que es justo), es en mayor medida la actuación del que no tiende tanto a hacer cosas justas como a actuar como actúa el hombre virtuoso. ${ }^{64}$

\section{UN EPÍLOGO POSIBLE}

35. Parece mejor descartar esta "posibilidad siempre presente", que sería trasladar "la generalidad del imperativo categórico kantiano" a la justicia que hace las leyes o las sentencias, para conocer la justicia de cada caso. Porque desconoce la singularidad de cada ser humano, y porque no tiene en cuenta la humanidad del hombre, que es más que un cazador de cosas "para ser feliz".

36. Ciertamente, frente a las filosofías anteriores a la Edad Moderna, según los moderni plagadas de una metafísica vacía, de finalidades incomprobables y de qualitates occultae, ${ }^{65}$ siempre el talante de Helvetius o de Bentham parece más realista, más adherido a la realidad. ${ }^{66}$ Como los siglos XIX y XX han demostrado las inhumanidades que podemos come-

64 Los textos fundamentales vienen contenidos en la p. 58, artículos 1 a 7 de la parte citada de la Suma teológica.

65 Me parece que la declaración programática más conseguida contra la metafísica preilustrada fue la de D'Holbach: “Mais pour connoître l'homme, il ne faut pas, comme il est arrivé très souvent, à l'aide d'une métaphysique incertaine et trompeuse, rechercher les ressorts cachés qui la remuent, il suffit de considérer l'homme tel qu'il se présente à notre vue, tel qu'il agit constantement sous nos yeux[...]". Cfr. La Morale.., cit., L. I, p. 5.

66 El propio Bentham basaba en esta cualidad los méritos de su método: "In the fourth place, a natural arrangement as it is by principle which is recognised by all men, will serve alike for the jurisprudence of all nations". Cfr. An Introduction to the Principles of Morals and Legislation, cit., vol. II, chap. XVI, LX, p. 220. Poco antes había indicado que un método "tan natural" como el que él propone poseía varias ventajas. Cfr. op. cit., chap. XVI, LVII, p. 216. 
Este obra forma parte del acervo de la Biblioteca Jurídica Virtual del Instituto de Investigaciones Jurídicas de la UNAM www.juridicas.unam.mx

https://biblio.juridicas.unam.mx/bjv

ter siguiendo la mayor felicidad del mayor número, ha sido preciso releer a estos filósofos, y les hemos añadido un matiz normativo. Pero la explicación final, combinando lo empírico con el dato normativo, resulta más cargada de oscuridades que las filosofías pre-modernas que había que combatir. $\mathrm{Y}$ es penoso que, tras haber combatido lo metafísico por irracional, ahora desterremos la razón en nombre de nuestras creencias.

37. Nosotros tendemos a pensar que la intersubjetividad contrastada de nuestros criterios suple cualquier otra ilusoria objetividad. Ésta no es una explicación seria, porque consensos fácticos han existido muchos a lo largo de la historia. Y buscar un consenso contrafáctico basándonos en las premisas fácticamente compartidas es algo más que una contradicción lógica. Según Paul Watzlawick, fundador de la Escuela de Psiquiatría de Palo Alto, las contradicciones pueden ser lógicas y pragmáticas. Me interesan ahora estas últimas, porque me parece que son las que realmente denuncian una imposibilidad vital. Y en el momento de generalizar pero pretendiendo obtener resultados propiamente normativos, de modo que lo general deje de ser tal para llegar (¿imperceptiblemente?) al plano universal, nos adentramos por mal camino.

38. Cualquier persona puede pretender racionalidad alegando un concepto universal: "un padre se comporta así con sus hijos pequeños", y entonces puede que se sitúe en una situación realmente normativa, y que recuerde un deber. Por contra, si se nos quiere obligar o forzar a actuar alegando generalidades, temo que hemos abandonado el plano de la moral y entramos por un camino sociológico, por el que un gobernante nos puede forzar. En tal caso el derecho se convierte más bien en el látigo del rebañero para aquellas personas que no comparten el interés mayoritario. ${ }^{67} \mathrm{Y}$, planteadas así las cosas, ¿qué título puede alegar la mayoría para imponerse a las minorías? ${ }^{68}$

67 Fue lógico el radicalismo de Harrison: "The proposition is most useful in drawing attention to this: That law is always a matter of necessity-it is never 'ought', but always 'must'; in that sense it is always and everywhere imperative". Cfr. On Jurisprudence and the conflicts of Law, Oxford, 1919, p. 37. Se trataba de una opinión emitida en el momento de máximo optimismo del "positivismo" que defendía que el derecho se compone sólo de leyes generales. Según informaba James Lorimer, esta distinción terminológica provenía de la doctrina alemana: "To use a German distinction, which I fear is hardly translatable, they are thus Soll-Gesetze, thougt not Muss-Gesetze (Krause, Rechtsphilosophie, p. 36), (ought-laws, not must-laws)". Cfr. The Institutes of Law, cit., p. 4.

68 Lorimer denunciaba que a los intentos utilitaristas ingleses les faltaba un homo noumenon kantiano que dictara infaliblemente lo que es conveniente: "To an omniscient mind the 'a posteriori' method would, no doubt, yield conclussions universally valid, end we cannot speak of it of its application as impossible". Cfr. The Institutes of Law, cit., p. 48. 
Este obra forma parte del acervo de la Biblioteca Jurídica Virtual del Instituto de Investigaciones Jurídicas de la UNAM www.juridicas.unam.mx

https://biblio.juridicas.unam.mx/bjv

39. Lamento parecer tan kantiano y tan hegeliano simultáneamente. Kant propuso la superación del arbitrio mediante la sumisión a un orden moral ya dado que habríamos de reconocer personalmente. Hegel insistió en la realización de lo real concreto como el único camino para superar la voluntad abstracta que llevaba a la "libertad del vacío", que se limitaba a excluir a los demás en nombre del propio arbitrio y que nos dejaba abandonados a la contingencia. ${ }^{69}$

Unas propuestas clarificadoras, pero que dejan muchos vertientes del problema sin tocar.

40. Kant sometió al individuo, también interiormente, al orden moral objetivo. Hegel quiso la realización humana en el verdadero camino de la eticidad. La opción ilustrada por los derechos sigue operando en ellos, porque uno y otro siguen viendo al individuo frente a las normas, sólo que en lugar de enfrentar a cada persona con cada una de ellas, estos pensadores quisieron reconciliar a una y otra parte globalmente: a los seres humanos singulares con lo universal.

El problema se sitúa en que este universal fue enunciado en forma abstracta-general: la consistencia de la acción consigo misma, o la reconciliación de la voluntad abstracta (en el sentido hegeliano) con lo sustancial en sí y por sí. Realmente, ¿es posible encontrar un único esquema heurístico o normativo que designe lo verdaderamente ético para todas las conductas e instituciones jurídicas? Parece que Kant y Hegel perdieron de vista en demasía que las cosas suelen ser como se presentan: múltiples, dispersas, abigarradas, no reductibles unas a otras en un plano superior y común. No existe un lenguaje superior, detrás de las cosas, que despeje universalmente nuestras dudas. Ni el procedimiento del imperativo categórico que nos muestra lo en sí necesario, ni el etiquetamiento de lo real concreto para todo lo que aprobemos hacen justicia a esta pluralidad y complejidad de la realidad. ${ }^{70}$

69 "La determinación kantiana admitida generalmente, cuyo momento central es "la limitación de mi libertad o arbitrio de modo tal que pueda coexistir con el arbitrio de todos de acuerdo con una ley universal", contiene sólo una determinación negativa: la de la limitación.

Por otra parte, lo que tiene de positivo la ley racional universal (o por lo menos así llamada), es decir, la concordancia del arbitrio de uno con el arbitrio de otro, desemboca en la conocida identidad formal y en el principio de no contradicción. La definición citada contiene la opinión, muy difundida desde Rousseau, según la cual "el fundamento esencial y primero no es la voluntad en cuanto racional [...] sino en cuanto voluntad del individuo según su propio arbitrio [...] Una vez aceptado este principio, lo racional sólo puede aparecer como una limitación para mi libertad". Cfr. Principios de filosofía del derecho..., cit., 29.

70 En el hombre operan principios de acción distintos, que se sitúan en un cierto plano de igual- 
Este obra forma parte del acervo de la Biblioteca Jurídica Virtual del Instituto de Investigaciones Jurídicas de la UNAM www.juridicas.unam.mx

41. Al jurista le cuesta trabajo entender esta mentalidad más propia de un talante filosófico, presente subliminalmente en casi todas las personas, que habla de individuos y normas. En el caso del derecho penal - que compone una parte muy distinta del resto del derecho- sí la entiende: esta rama del derecho contempla unos seres individuales o personalidades completas en sí mismas, y por este motivo no fomenta ni posibilita: únicamente defiende contra atentados directos en la personalidad, ${ }^{71}$ sean exactamente en la persona, sean en otras manifestaciones de la personalidad: propiedades, honor, etcétera. El derecho penal sólo reclama normalmente la "abstención", una Enthaltung, ante lo que los demás son y tienen.

Pero el resto del derecho no tiene esta naturaleza. El derecho civil o mercantil son a modo de cajas de herramientas que posibilitan que cada persona humana llegue a tener lo que aún no tiene, o llegue a ser lo que aún no es. No se limita a defender las personalidades.

El derecho que no es derecho penal tiene en cuenta la personalidad humana (iquién procesaría a un animal!) y recurre a ella a veces, cuando considera temas tan generales como el de la buena fe o el de la causation. Pero aquí se detiene. Porque este derecho, que posibilita y calcula, no puede extraviarse por el campo infinito de la personalidad. El derecho consiste en medir, y no podemos medir el valor incalculable de cada persona: ${ }^{72}$ el derecho mide de acuerdo con "las cosas", esto es, según la naturaleza de las instituciones concretas que nos vinculan en este momento. Porque, otra vez a diferencia del derecho penal, el derecho no nos defiende contra los demás ni nos enfrenta a ellos: nos vincula, porque el derecho es el arte que posibilita que cada cual (como persona privada, pero relevante jurídicamente) sepa dirigir la vida de los demás. Mis alumnos

dad ante la ética. Lo recordaba lord Kames en Essays..., cit., p. 106. El método dominante en el siglo XVIII pretendía considerar uno solo, y así sucedía que "those which remains, acting now without opposition from their antagonist forces, will disordes the balance". Cfr. idem.

71 Cuando está en juego la personalidad humana, el derecho la defiende, esto es, ordena abstenciones. Así lo expresaba Austin: "I noticed the rights of the class of which the subjects are 'persons', or of which are such forbereances as determinately regard specifically determined persons". Cfr. Lectures on Jurisprudence..., cit., p. 793.

72 Lorimer señalaba que tampoco los derechos humanos pueden ser entendidos como derechos absolutos: "We have seen, moreover, in each particular instance, that the rights of which we become conscious are not absolute and unlimited, but relative to, and circunscribed by, the powers in which they innere". Cfr. The Institutes of Law, cit., p. 236. 
Este obra forma parte del acervo de la Biblioteca Jurídica Virtual del Instituto de Investigaciones Jurídicas de la UNAM www.juridicas.unam.mx

https://biblio.juridicas.unam.mx/bjv

invaden continuamente mi vida, y yo las de ellos: y sobre este punto, de poco sirve el esquema interpretativo del derecho de la personalidad. ${ }^{73}$

Desde estas cosas surge cotidianamente la universalidad ética perdida por los ilustrados: la índole de la ocupación de profesor determina (con cierta objetividad) lo que mis alumnos me pueden exigir normativamente, y lo que yo puedo exigirles a ellos creándoles un deber. Pero nos perderíamos en los inmensos espacios de lo posible si consideráramos nuestras personalidades. ${ }^{74}$

42. Va siendo el momento de revisar nuestra selección de los derechos. Frente a las desigualdades jurídicas del Antiguo Régimen (sería más preciso decir de la mentalidad propia de la antigüedad) hemos recabado la igual personalidad, y esto ha constituido — al menos para míun avance humano. Pero un exceso de personalismo nos ha llevado a perder muchas fuentes de la universalidad ética. Y sucede que quizá ahora es el momento de comenzar a recabar los derechos de las cosas. ${ }^{75}$ (siempre medibles imprecisamente, pero medibles normalmente), sobre los derechos de las personalidades, que en su inconmensurabilidad dejan el campo académico abierto a posibilidades vacías de la imaginación.

73 Holland, siempre preciso aunque no sea cuestión de compartir todas sus opiniones, nos advertía sobre este problema de la personalidad: "Its is a mere choice of the more convenient course whether the jurits makes the 'personal' dimension of the right or its 'real' dimension the basis of his classification. Now as a matter of the fact the personal dimension is one which in the majority of cases need no consideration at all". Cfr. Elements of Jurisprudence, cit., p. 140.

74 El lector dispone de una explicación más extensa de este tema en mi estudio Persona y 'officium': derechos y competencias, ya citado.

75 Adoptar esta actitud tan metafísica — hablando de "cosas" - puede extrañar al lector actual, quizá influido todavía por el talante que representaron Neurath, Carnap o Russell. Quien así sienta, puede consolarse pensando que, si considera las cosas no incurrirá en las estimables contradicciones de Hobbes, para quien un "pensamiento" era "one a 'representation' or 'appareance', of some quality, or other accident of a body without us, which is commonly called an object". En cambio, la razón constituía una "realidad objetiva". Vid. los capítulos 1 a 5 del Part I del Leviathan. 


\title{
LOS DERECHOS Y DEBERES DEL HOMBRE*
}

\author{
Francesco d'AGOSTINO
}

\author{
SUMARIO: I. Los derechos del hombre. II. Los deberes del
} hombre.

\section{LOS DERECHOS DEL HOMBRE}

\section{Cómo rescatar Auschwitz}

Hablando en la XXXIV Asamblea General de la ONU, el 2 de octubre de $1979,{ }^{1}$ Juan Pablo II, recordando el peregrinaje que algunos meses atrás había hecho a Auschwitz, afirmó que particularmente aquellos terribles sufrimientos que habían implicado a millones y millones de personas motivaron la proclamación, el 10 de diciembre de 1948, de la Declaración Universal de los Derechos del Hombre, que para la ONU constituye la piedra angular. ${ }^{2}$ Un precio tan alto y tan trágico, debería inducir a todos los hombres a no derrochar en vano aquel patrimonio de valores que si es, por así decirlo, condensado en la Declaración, y que constituye, quizá, el único modo, para la humanidad de nuestro siglo, de tomarse en serio, si acaso es posible, la vergüenza de la que se manchó al construir los campos de exterminio. ${ }^{3}$

* Traducción del italiano hecha por Javier Saldaña Serrano en colaboración con Mónica W. Mata Espinosa y Hugo S. Ramírez García.

1 El discurso del papa puede ser leído en AA.VV., Jean Paul II et les droits de l'homme, Fribourg, 1980, pp. 112 y ss. Cfr. también, F. Biffi, "I diritti umani da Leone XII a Giovanni Paolo II", en I diritti umani. Dottrina e prassi, a cargo de G. Concetti, Roma, Ave, 1982, pp. 226 y ss.

2 Un analítico y partícipe comentario a la Dichiarazione es aquel de G. Capograssi, como introducción a la tr. it. de la Dichiarazione universale dei diritti dell'uomo, vol. V, Padova, 1950, pp. 37-50.

3 Tomar en serio, no rescatar, redimir, o, peor todavía, justificar Auschwitz no es justificable, no sólo en el plano histórico y político, sino mucho más sobre el plano ético: no es justificable porque "la justification de la douleur du prochain est certainement la source de toute immoralité" (cfr. E. Lévinas, "La souffrance inutile", en Giornale di Metafisica, nueva serie, núm. 4, 1982, p. 22). 
Este obra forma parte del acervo de la Biblioteca Jurídica Virtual del Instituto de Investigaciones Jurídicas de la UNAM www.juridicas.unam.mx https://biblio.juridicas.unam.mx/bjv

La observación del papa es invaluable, desde diversos puntos de vista. Es invaluable, en primer lugar, en virtud del discurso en sí mismo, un discurso que no teme de ser tal, de enfrentarse, es decir, en el nombre de una paciente confianza en el logos, contra aquella "imposibilidad de hablar que es quizá la experiencia más incontestable de nuestra época". ${ }^{4}$ Es invaluable históricamente, porque es sin lugar a dudas, ${ }^{5}$ que (fue el horror del mundo entero, atestiguar tantas muertes atroces - aquellos esqueletos, aquellos hornos - lo que condujo a la Declaración Universal de los Derechos del Hombre). ${ }^{6}$

Sin embargo, sociológicamente es todavía más valiosa, porque si se dice que nuestro tiempo es el tiempo de los derechos humanos, esto es el producto no de la afirmación de una particular especulación filosófica, no del triunfo de una doctrina (fenómenos éstos en definitiva intelectuales, abstractos, a límite ideológico), sino de un sentido ético concreto, que sólo en nuestro tiempo resulta, por los motivos que señalamos, catalizado e instalado definitivamente en las conciencias. Es como si la confianza en los valores, que parece haber sido abandonada por tantos pensadores de nuestro tiempo, esté, en cambio, radicada, en la opinión común, gracias a la tragedia histórica en la cual Auschwitz llegó a ser el símbolo definitivo, ${ }^{7}$ viniendo casi a constituir una clase universale etico, que ninguna época del pasado había conocido: un decálogo para cinco millones de individuos. ${ }^{8}$ Frente a este dato fáctico — si se desea, todavía no plenamente explícito, pero en sí incomprendido por parte de los estudiosos "poco sentimentales" — 9 pierde importancia la crisis del iusnaturalismo, es decir, el

4 Así E. Lévinas, "Senza identitá”, en E. Lévinas, Umanesimo dell'altro uomo, tr. it., Génova, 1985, p. 152, núm. 14. Continúa Lévinas: "Oímos el discurso con solemnidad insoportable, declamación y sermón. De manera que no nos alcanza de hablar y escuchar sin disgusto otro discurso que no sea aquél algorítmico de la ciencia, el cotidiano: 'me da un vaso con agua' — y ser tentados por el discurso violento- ya grito, destructor del dicho" (ibid.).

5 Lo ha admitido, por ejemplo, M. Novak, representante de Estados Unidos de Norteamérica ante la Comisión de los Derechos del Hombre en la ONU, en un discurso pronunciado el 1 de mayo de 1981, en ocasión de la conmemoración de los dieciséis millones de víctimas del holocausto nazista. El discurso de Novak, titulado "Il primato dell'individuo e il progresso economico" puede ser leído en tr. it. en Prospettive americane, julio 1981, pp. 47 y ss.

6 Novak, M., op. cit.

$7 \mathrm{Al}$ punto que fue posible sostener — del todo a razón- que el nuevo imperativo categórico de nuestro tiempo es: que Auschwitz non si ripeta. Cfr. Adorn, T. W., Dialettica negativa, tr. it., Torino 1970, p. 370; cfr. también Neher, A., L'esilio della parola. Dal silenzio biblico al silenzio di Auschwitz, tr. it., Casale Monferrato, 1983, pp. 151 y. ss.

8 Como subraya eficientemente Cassese, A., "La dichiarazione universale dei diritti umani, quaranta anni dopo", in A. Cassese, I diritti umani nel mondo contemporaneo, Roma-Bari, 1988, p. 42.

9 Así es calificado Max Weber por E. Topitsch, cuando recuerda la plena adhesión a una 
tradicional fundamento teórico de los derechos del hombre, o la lenta, pero constante difusión (sólo en el mundo occidental) de un nihilismo adulador; poco cuenta la diversidad de las lenguas y de las culturas, aspecto que todavía divide duramente a los hombres; ${ }^{10}$ la confianza en los derechos humanos se revela en nuestro tiempo activa y generosamente operante, se revela como la verdadera "corriente candente" capaz de convertir el pensamiento en praxis, de construir un página nueva en la historia.

Ya durante los últimos años del nazismo hubo propiamente un llamado a los derechos del hombre (además de la fe católica), a motivar idealmente uno de los pocos movimientos de resistencia contra el genocidio, aquel de la "Rosa Blanca" de los hermanos Scholl;"11 a los derechos humanos se refirió en los Estados Unidos el movimiento antisegregasionista de Martín Luther King; sobre los derechos humanos, sobre su universal defensa, sobre su promoción universal, si bien siempre más centralizado, a causa de las miles de dificultades, el nuevo derecho internacional, que liberándose de sus viejos mitos constitutivos, como aquel decimonónico del "sacro egoísmo de la patria", ha descubierto propiamente en la dignidad del hombre su nuevo objetivo, su nuevo centro de gravedad; ${ }^{12}$ sobre

concepción de los derechos del hombre "como presupuesto irrenunciable de una existencia digna de ser vivida" ("I diritti dell'uomo come problema di critica dell'ideologia", in E. Topitsch, A serche serve l'ideologia, tr. it. Bari, 1975, p. 95).

10 Los divide, sí, pero sin perjudicar la unidad fundamental de la experiencia humana. Pieper subraya acerca de cómo propiamente el tema de los derechos humanos, también si léxicamente y conceptualmente típico del Occidente, sea sin embargo objetivamente transcultural, como puede advertir cualquiera que tenga la capacidad de saberlos tomar por su espíritu intrínseco. Por ejemplo - advierte Pieper - en los debates en la ONU que precedieron a la emanación de la Declaración de Derechos, surge la dificultad de traducir literalmente, en lenguas diversas de aquellas occidentales, la misma expresión "derechos del hombre"; empero, si acudimos de inmediato que eso que faltaba era sólo un término, no cierta la posibilidad de restituir la valía profunda, o si se desea, el espíritu de esta expresión, con expresiones diferentes, diversamente radicadas en el contexto semántico de otras lenguas, sin embargo objetivamente equivalentes. Así, en chino la expresión "derechos del hombre" fue adoptada recurriendo a una antiquísima admonición, que literalmente dice en el modo siguiente: $i l$ cielo ama il popolo e chi governa deve ubbidire al cielo "el cielo ama al pueblo y quien gobierna debe obedecer al cielo" (cfr. Pieper, J., "Das Recht des Anderen”, en J. Pieper, Über die Schwierigkeit heute zu glauben, München, 1974, p. 229). Cfr. también Lewis, S. C., L'abolizione dell'uomo, tr. it., Milano, 1979, pp. 83 y ss.

11 La historia de este movimiento fue contada por Scholl, I., La rosa bianca, tr. it., Florencia, 1956. Cfr. también la recientísima colección de AA.VV., Die Weisse Rose und das Erbe des feutschen Wiederstandes, München, 1993.

12 Cfr. Verdross, A., Statisches und dynamisches Naturrecht, Freiburg, 1971, pp. 90 y ss., y la amplia colección de estudios a cargo de Theodor Meron y titulada Human Rights in International Law. Legal and Policy Issues, 2 vol., Oxford, 1984. Importantes también las contribuciones de Casadio, Villani, Napoletano y Schiavone en la obra colectiva I diritti umani, cit., pp. 247 y ss. 
Este obra forma parte del acervo de la Biblioteca Jurídica Virtual del Instituto de Investigaciones Jurídicas de la UNAM www.juridicas.unam.mx

https://biblio.juridicas.unam.mx/bjv

FRANCESCO D'AGOSTINO

la valerosa defensa de los derechos humanos (más allá de cada particularismo nacional e ideológico) se funda la universal competencia conquistada en todo el mundo por organizaciones como Amnesty International; ${ }^{13}$ ha sido olvidado en estos últimos años, intensísimos años, en los países del Este el Samizdat —un fenómeno complejo y ramificado, que para nosotros se concentró en pocos nombres, como aquellos de Sacharov o de Solzenicyn, pero que implicó a miles de personas destinadas a permanecer desconocidas - se nutrió de este ideal y hace la articulación, el punto de conjunción — no político, no ideológico, pero sí precisamente humano- entre las dos mitades del mundo; ${ }^{14}$ el derrumbe del régimen soviético en los países del Este tuvo como fuerza ideal atrayente lo referido a los derechos del hombre. ${ }^{15}$ En conclusión, los derechos humanos - el prodigio de la Edad Moderna— ${ }^{16}$ representan realmente una revolución cultural de incalculables proporciones. ${ }^{17}$

\section{Los derechos, irrenunciables e irrealizables}

Las consideraciones recién hechas no tienen, ni deben tener, algún carácter triunfalístico. De éstas deben permanecer lejanas cada énfasis y cada elocuencia: nunca, como en este caso, se necesita tomar en serio la advertencia hegeliana, de que el pensamiento evite hacerse "edificante". En efecto, si de una parte comprendemos la temática de los derechos humanos como culturalmente irrenunciables, es decir, como definitivamente encarnada en el mundo contemporáneo, por otro lado, una observación fría y sin prejuicios, la muestra como largamente irrealizada histórica-

13 Cfr. Weissbrodt, D., "The Contribution or International Nongovernamental Organizations to the Protection of Human Rights", en T. Meron, op. cit., vol. II, pp. 403 y ss., E. de Giorgi y C. Sbordone, "Le denunce di Amnesty International”, I diritti umani, cit., pp. 839-850.

14 Sobre Samizdat y sobre su reivindicación de los derechos humanos ha justamente insistido I. Mancini, Filosofia della prassi, Brescia, 1986, pp. 67-68. Sobre el estatuto de los derechos en la URSS, cfr. Revendin, A. M., La negazione teoretica. Idiritti dell'uomo e la critica de Marx, Padova, 1985, en parte pp. 113 y ss. También se caracterizó de un tono más evidente ideológico, $c f r$. Geissler, H., "Menschenrechte und Marxismus", en Conturen, núm. 8, 1987, pp. 18-31. Cfr. también, Codevilla, G., "I diritti umani nelle costituzioni dell'Europa orientale", en I diritti umani, cit, pp. 457-472.

15 Algunos señalan también la hipótesis que haya sido la religión la que provocó el fin del comunismo, por su capacidad de mantener viva en las conciencias de los hombres la idea de una firme competencia, de un derecho fundamental e inviolable, el cual profesara abiertamente su fe. $C f r$. acerca de Pedrazzi, L., "Religione e fine del comunismo", en Orientaciones sociales, núm. 2, 1990, pp. 56-62.

16 Como los ha definido I. Mancini, Giustizia pel il creato, Urbino, 1989.

17 Así Cotta, S., "I diritti dell'uomo: una rivoluzione culturale", en Persona y Derecho, núm. 22, 1990*, pp. 13-36. 
Este obra forma parte del acervo de la Biblioteca Jurídica Virtual del Instituto de Investigaciones Jurídicas de la UNAM www.juridicas.unam.mx

https://biblio.juridicas.unam.mx/bjv

mente. (Parece — ha escrito Sergio Cotta- que la traducción en términos jurídicos de la idea filosófica de los derechos del hombre no haya aumentado del todo la garantía y la eficacia práctica y concreta). ${ }^{18}$ Es propiamente en esta dialéctica entre irrenunciabilidad e irrealizabilidad donde se coloca el tormento de nuestro tiempo, donde se radica el imperativo ético más significativo de nuestra época.

¿Por qué los derechos humanos son en gran parte irrealizables, defectuosos, ${ }^{19}$ incluso en aquellos ordenamientos que los han constitucionalizado? ¿Es porque, también cuando son, al menos tendencialemtne realizables (como en las grandes democracias occidentales) son cumplimentados así de mal?

No es simple responder a una pregunta similar. Existen ciertamente motivaciones históricas bien precisas de la violación de los derechos del hombre, que varían de país a país, de régimen a régimen, y que requieren un análisis meticuloso (por muy diversos motivos, por ejemplo, los derechos humanos son reprimidos en China y en el sur de África); sin embargo, creo que las razones más profundas de las dificultades que encuentra una plena realización de los derechos son, en definitiva, metahistóricas; las cuales se adhieren al mismo modo de pensar de tales derechos. Sintetizaré aquellas que me parecen las razones más importantes, advirtiendo de antemano que el orden de su presentación no tiene un sentido jerárquico; aquellas que, atendiendo a diversos ámbitos de la experiencia y del pensamiento, tienden a sobreponerse recíprocamente y pueden ser distintas sólo en abstracto, recurriendo claramente a esquematizaciones.

\section{Los límites de los derechos del hombre}

En primer lugar podemos subrayar que los derechos humanos conocen un límite esencialmente político, sobre el cual ha lúcidamente insistido con eficacia y vehemencia, entre tantos otros, Jaspers. ${ }^{20}$ Los derechos humanos valen, en efecto, hoy por hoy, para los ciudadanos de un Estado,

18 Cotta, S., "Il fondamento dei diritti umani", I diritti umani, cit, p. 645.

19 Como los define sutilmente Podgorecki, A., "Verso una sociologia dei diritti dell'uomo", en Sociología del derecho, núm. 16, 1989, p. 132.

20 Cfr. Jaspers, K., "L'inaffidabilitá dei diritti dell'uomo", en K. Jaspers, Veritá e verifica. Filosofare per la prassi, tr. it., Brescia, 1986, pp. 211-218. Este punto fue bien argumentado también por N. Bobbio, en diversas ocasiones: $c f r$. por ejemplo "Presente e avvenire dei diritti dell'uomo", en N. Bobbio, L'etá dei diritti, Torino, 1990, pp. 17 y ss. Se observa también en Maihofer, W., "Die Würde des Menschen als Zweck des Staates”, en Anales de la Cátedra Francisco Suárez, núm. 12, 1972, pp. 37-62. 
Este obra forma parte del acervo de la Biblioteca Jurídica Virtual del Instituto de Investigaciones Jurídicas de la UNAM www.juridicas.unam.mx

https://biblio.juridicas.unam.mx/bjv

FRANCESCO D'AGOSTINO

que se ha empeñado formalmente en reconocerlos. En suma, la garantía dentro del Estado todavía no protege una análoga garantía, para el hombre que reivindica la violación de sus derechos fundamentales contra el Estado. Hasta que no exista una ciudadanía planetaria, la eficacia de los derechos será siempre estructuralmente limitada. Los límites estatutarios y el particularismo político representan, pues, un primer objetivo, grave límite a la plena actuación de los derechos humanos.

Un segundo problema es de carácter estructural, que se atiene a la lógica propiamente jurídica, la cual es subordinada a la efectiva defensa institucional de los derechos. Todos los juristas saben que es posible definir al derecho como un sistema vuelto a mediar pretensiones individuales conflictuales. En la laureada definición kantiana, lo específico del derecho es establecido propiamente por éste, esta mediación deviene institucionalmente, en el signo de la maximización de la libertad de todos.

Por tanto, un sistema que desea reconocer, proteger y promover los derechos del hombre encuentra una indudable y preliminar dificultad: parece que ningún derecho individual puede ser reivindicado por un sujeto sin que venga en cualquier modo limitado por el derecho concurrente de uno de los demás sujetos. La realización de los derechos humanos sería, pues, constitutivamente parcial y en cualquier modo inadecuada, si no, directamente negatoria (respecto al menos de las aspiraciones). Nos encontramos frente a una antinomia ciertamente compleja, al punto que es considerada, por parte de muchos, prácticamente imposible. La dificultad nace, probablemente, de confundir el estatuto específico del conflicto de derechos, con aquel del conflicto de valores; es tal vez porque los valores son generalmente considerados como no jerarquizables, ${ }^{21}$ le sigue coherentemente la imposibilidad de resolver en términos de justicia cada controversia que a ellos se refiere, si no recurriendo a un acto decisionístico; un acto, o sea, que puede sí poner fin a la cuestión, mas sólo porque la trunca bruscamente, no porque reconozca cuáles son $o b$ jetivamente los que corresponde a cada una de las partes en conflicto. Sin

21 El punto, obviamente, no es del todo pacífico; no es de cualquier modo el caso de someterlo a un examen minucioso, dato que es en el fondo intranscendente en el contexto de nuestro discurso. Vale sólo la pena observar que más fundada aparece la opinión de quien en cambio señala que la misma existencia humana requiera, como presupuesto suyo, por decirlo así, de existencia, la posibilidad de resolver de cualquier manera el conflicto, jerarquizándolos. No consistiría en definitiva, la reflexión moral, como facultad humana universal. Insiste mucho sobre este punto, como esencial para una justa concepción del derecho, Welzel, H., "Recht und Sittlichkeit", en Festschrift Schaffstein, Göttingen, 1975, p. 47. 
Este obra forma parte del acervo de la Biblioteca Jurídica Virtual del Instituto de Investigaciones Jurídicas de la UNAM www.juridicas.unam.mx

https://biblio.juridicas.unam.mx/bjv

embargo, no se moraliza el derecho, es decir, se ve el conflicto de los derechos por aquello que es, esto es, un conflicto entre opuestas pretensiones jurídicas subjetivas, y no entre valores opuestos, ${ }^{22}$ la solución de la antinomia, por difícil que sea, puede ser encontrada. De hecho, la misma reivindicación de un derecho es posible sólo en cuanto, al menos implícitamente, con el mismo que la propone la reconozca como objetiva (válida, o sea, en línea de principio, para cualquiera que se encuentre en la misma situación en la cual él se encuentra); mas no la reivindicación de un derecho, porque entonces se debería de hablar de la reivindicación de un privilegio. El conflicto entre derechos puede, por lo tanto, ser resuelto recurriendo al criterio (de matriz kantiana) de la universalidad: merece ser objetivamente tutelado aquel derecho que no es, o de cualquier modo menos que otro, conflictivo, que tiene el carácter del indebido privilegio. Un concreto balance de los derechos requiere, por consiguiente, una gran sabiduría jurídica, que va, quizá, también más allá de la mera (obviamente indispensable) buena voluntad, y de los jueces y del legislador: requiere el saber y el querer poner un freno en nombre de la universalidad del derecho a las eventualidades (y no poco frecuentes violencias) instancias de afirmación ilimitada de las pretensiones subjetivas, que alterando la simetría sobre la cual se funda cada justo equilibrio social, se traducen en un atropello objetivo de los más fuertes sobre los más débiles. ${ }^{23}$

\section{El derecho de tener derechos}

El punto, a mi parecer fundamental, a partir del cual se debe reflexionar cuando se considera el tormentoso problema de la idealización de los derechos del hombre, es aquel de la proliferación de las cartas de los derechos. En 1978, para celebrar el trigésimo aniversario de la Declaración Universal de los Derechos del Hombre, la Organización de las Naciones

22 Esta exigencia es lúcidamente advertida por Ollero, A., "Para una teoría 'jurídica' de los derechos humanos”, Revista de Estudios Políticos, 1983, núm. 35, pp. 103-122. (Ahora también en A. Ollero, Derechos humanos y metodología jurídica, Madrid, 1989, pp. 149 y ss.). Si examinan las justas consideraciones de Viola, F., "Il nuovo ruolo dei diritti dell'uomo", Per la filosofía, núm. 1, 1984, pp. 15-22, ahora también en F. Viola, Diritti dell'uomo, diritti naturale, etica contemporanea, Torino, 1989, pp. 157-170.

23 Es el riesgo sobre el cual llama eficazmente la atención S. Cotta, "L'attuale ambiguitá dei diritti fondamentali”, en Revista de Derecho Civil, núm. 23, 1977, pp. 225-242. Consideraciones análogas, que también se llevan adelante en una prospectiva diversa, son aquellas de M. Villey, Le droit et les droits de l'homme, París, 1983, en parte, pp. 15 y ss. 
Este obra forma parte del acervo de la Biblioteca Jurídica Virtual del Instituto de Investigaciones Jurídicas de la UNAM www.juridicas.unam.mx

https://biblio.juridicas.unam.mx/bjv

Unidas publicó un documento oficial, en el cual se reunieron ochenta y ocho textos de declaraciones de derechos humanos, desde Bill of rights de 1689 a la Declaración de los derechos de los inadaptados de 1975. Desenredarse de esta selva, crecida desordenadamente en trescientos años, no es fácil. ${ }^{24}$ No parece que esta dinámica disminuya; y si la cuestión legal de difícil solución medieval (brocardo) motus in fine velocior tiene un fundamento, hay que temer que la proliferación incontrolada de cartas de los derechos pueda ser el pródromo de la crisis definitiva de este instrumento de defensa de los derechos del hombre.

En realidad, por arriba de este multiplicarse de las cartas de los derechos está una exigencia profundamente respetable: aquella de maximizar la tutela de los individuos, enumerando con la mayor precisión posible sus competencias. Es ésta, en el fondo, una exigencia que inmersa cíclicamente en la historia, también se da en formas aparentemente muy diversas entre ellas; si se piensa en la gran época casuística (y en su aspiración de poder próbidamente prever con anticipo todos los posibles casos de conciencia) o aquella del iusnaturalismo moderno (que ha multiplicado por tomos y tomos el estudio a priori del derecho, olvidando la sobriedad de la tradición iusnaturalista medieval, en particular de aquella tomista); es la exigencia, en suma, la cual claramente los estudiosos saben resistir, de alcanzar, de todos modos, una conclusión, de obtener de todos modos la totalidad.

Es una exigencia respetable, ciertamente, aquella de multiplicar las declaraciones de los derechos; una exigencia que quizá va, sin más, definida preciosa, en un tiempo como el nuestro en el que la incapacidad de encontrar a los derechos un fundamento de carácter teorético, busca sin embargo, de garantizarles al menos un fundamento estable positivo. ${ }^{25}$

24 Así Gentile, F., Intelligenza politica e ragione de Stato, Milán, 1983, p. 74. E. Vitta y V. Grementieri han reunido un Codice degli Atti internazionali sui diritti dell'uomo (Milán,1981) que constituye un notable testimonio de cuanto se ha detallado (a nivel de declaraciones, se entiende) la defensa de los derechos humanos. Todavía útil la vieja colección, a cargo de F. Battaglia, titulada Le carte dei diritti, Florencia 1946, que compromete a las verdades y propias declaraciones de los derechos una nutrida serie de documentos históricos, a partir de la Carta Magna de Enrique III en 1225. Para la documentación sobre un problema como aquel de los derechos de la infancia, muy particular, sin embargo ideológicamente central en nuestro tiempo, cfr. Nel nome dei bambini, textos presentados por A. Papisca, Milán, 1990 y A. T. Rella Cornacchia, I diritti del bambino. Dall'enunciazione all'attuazione, Génova, 1992.

25 Estable... y frágil al mismo tiempo, como cada fundamento secundum quid. No se puede de hecho estar de acuerdo con N. Bobbio, cuando sostiene que "el tema del fundamento [...] es tanto teoréticamente apasionante como prácticamente irrelevante" "Pro o contro un'etica laica", en $\mathrm{Il} \mathrm{Mu}$ lino, núm. 33, 1984, p. 170). Observa justamente S. Cotta (Il fundamento dei diritti umani, cit., p. 
Este obra forma parte del acervo de la Biblioteca Jurídica Virtual del Instituto de Investigaciones Jurídicas de la UNAM www.juridicas.unam.mx

https://biblio.juridicas.unam.mx/bjv

Empero, es también una exigencia ingenua, que hace venir a la mente el mito iluminístico del enciclopedismo (la idea, o más bien la pretensión ilusoria, de poder incluir en un solo texto, sea amplísimo y articulado, como justamente son las enciclopedias, todo el saber humano) o el mito, a esto correlativo, de la codificación del derecho.

Ciertamente, aquello del enciclopedismo es un mito inocuo, al menos hasta que se mantenga la conciencia de que la pretensión enciclopédica es, de por sí, estrechamente empírica; deviene, no obstante, peligroso si esta pretensión se absolutiza, es decir, en la enciclopedia se va a la búsqueda de la total perfección del conocimiento. ${ }^{26}$ Sería una grave ingenuidad pensar en poder describir satisfactoriamente, en una o más cartas de los derechos, eso que corresponde al hombre en cuanto hombre: por cuantos caminos, y confines del espíritu no los puede encontrar. ${ }^{27} \mathrm{La}$ totalidad del saber — también, y sobre todo del saber jurídico- no es nunca cuantitativa, sino cualitativa; no es entregada a la meticulosidad de la normativa (que en sí es bien laudable), pero a su saber toma con profundidad las exigencias y las líneas de sustentación de la realidad que es llamada a reglamentar. $\mathrm{Y}$ es por esto que, en todas sus dimensiones, allí comprendida aquella jurídica, la "sabiduría", como capacidad de unificar

647) que "si es controvertido el fundamento de los derechos, es inevitable que, primero o después, éstos resulten controvertibles también sobre el plano práctico; por eso un compromiso serio, duradero y general en su favor resultará por lo menos arduo y muy frecuentemente vano e inútil”. De aquí la exigencia de no dejar caer el duro trabajo (teóretico) de fundar los derechos, sin que por esto renunciar a dar, sea como fuere, valor a aquella forma, sea mínimamente, de fundamento empírico, que es constituida (para usar una vieja fórmula iusnaturalista) del consenso omnium gentium "con el argumento del consenso —escribe N. Bobbio, Presente e avvenire dei diritti dell'uomo, cit., p. 20 -se sustituye la prueba de la intersubjetividad a aquella retenida como imposible o extremadamente incierta de la objetividad. Cierto, se trata de un fundamento histórico, y como tal no absoluto: sin embargo, es el único fundamento, aquel histórico del consenso, que puede ser fáctimente probado". Se puede también decir, sin embargo, cualquier cosa de más: el "consenso del género humano" cuando no es el mero producto de tradiciones históricas de lejanos y complejos orígenes, más o menos accidentalmente concordantes (como fue probablemente en su tiempo el caso de la esclavitud); no obstante, el fruto de eventos históricos bien determinados, en los cuales ha participado y que han objetivamente involucrado a toda la humanidad (como aquel del holocausto, al cual tenemos como el punto de partida; o, si se desea otro ejemplo, como aquel del uso de la bomba atómica en Hiroshima), vine a adquirir un fundamento sui generis, ciertamente histórico, pero que sería reducido a permanecer frágil; es el concretísimo - y el más de las veces doloroso - fundamento de la experiencia, que vale para los pueblos así como para los individuos en lo singular. La experiencia puede ser negada, puede ser apartado; tiene, empero, una dura objetividad, diversa de aquella de la argumentación teorética; sin embargo, no por eso irrelevante o despreciada.

26 Cfr. acerca de las finísimas observaciones de Mathieu, V., "Dal'unità all'unificazione”, en AA.VV., L'unificazione del sapere, Florencia, 1964, pp. 41-62.

27 Así, el profundo dicho de Heráclito (22B45 Diels- Kranz). 
Este obra forma parte del acervo de la Biblioteca Jurídica Virtual del Instituto de Investigaciones Jurídicas de la UNAM www.juridicas.unam.mx

https://biblio.juridicas.unam.mx/bjv

las múltiples, de dar un nombre a la íntima unidad verdadera, renovada maravilla, respeto y admiración.

Los esfuerzos de las Naciones Unidas de determinar siempre mejor las competencias fundamentales de los hombres no son, sin embargo, criticados. Son un signo, a su modo, precioso. Pero no nos ilusione que la elaboración de siempre nuevos, siempre más detallados documentos, sea la vía maestra para defenderlos en el modo mejor posible. La vía maestra (si de verdad existe una) es otra y pasa a través de la conciencia que todos deben contribuir a defender, que el hombre sea garantizado verdaderamente, sólo cuando todos los derechos que se le reconocen sean reducidos a un único, y estable fundamento: el derecho de tener derechos - para usar una emblemática expresión de Hannah Arendt-;28 o más simplemente todavía, cuando a cada hombre le sea reconocido, por lo que cada hombre verdaderamente es: persona. ${ }^{29}$ Es en el saber tematizar las competencias de la persona - en su paradójico estatuto de (multiplicité non-aditionnable d_être uniques) — ${ }^{30}$ que se manifiesta sobre el grado más alto de la sabiduría de los juristas.

La lucha por la promoción y la defensa de los derechos humanos viene así a coincidir fundamentalmente con la lucha por el reconocimiento de la dignidad humana, es aquella que es su dimensión institucional, mínima y fundamental: la capacidad de cada hombre de ser "sujeto (y no mero objeto) de la razón";31 la capacidad de cada hombre en cuanto per-

28 Cfr. Le origini del totalitarismo, tr. it., Milán, 1967, p. 410.

29 Cfr. Cotta, S., voz "Persona" en Enciclopedia del diritto, vol. XXXIII, Milán, 1983, pp. 159 y ss. (ahora también en Cotta, S., Diritto, persona, mondo umano, Torino, 1989, pp. 59-82); Hattenhauer, H., "Person. Zur Geschichte eines Begriffs", en Juristische Schulung, 1982, pp. 405-411; Benedetti, V., "Uomo-persona”, en Corradini, Benedetti, Giovannini y Cappelletti, Hominum Causa. Il Diritto del suo esserci e nel suo farsi, Milán, Giuffrè, 1987, pp. 33-62; Melchiorre, V., "Per un’ermeneutica della persona”, en Melchiorre, V., Corpo e persona, Génova, 1987, pp. 21-36.

30 La expresión es de E. Lévinas, "Le droits de l'homme et les droits d'autrui, in indivisibilité des droits de l'homme, Actes du II Coloque Interuniversitaire", Friboug, 1985, p. 37 (tr. it. I diritti umani e i diritti altrui, en Lévinas, Fuori dal soggetto, Génova, 1992, pp. 121 y ss.). Lo paradójico de ser persona (el hecho, esto es, que la no intercambiable unidad de cada individuo, reposa propiamente sobre la identidad del género humano). Y la consiguiente, e igual, paradójica absoluta dignidad del hombre, vienen ejemplificadas por Lévinas, recurriendo a un sugestivo apólogo talmúdico: “¡Grandeza del Santo que es bendito! Aquí está el hombre que conoce todas las monedas de una sola impresión y obtiene pedazos, cada uno igual al otro; y aquí el Rey de los reyes, el Santo que es bendito, que conoce a todos los hombres a partir de la imagen de Adán, y ninguno se asemeja a otro. Y que por esto cada uno puede bien decir: el mundo fue creado para mí" (Talmud babilonio, tratado Synhedrin, 37a).

31 Es este il principio di personalità, sobre el cual S. Cotta funda su teoría de la justicia ( $c f r$. Il diritto nell'esistenza. Linee di ontofenomenologia giuridica, Milán, 1985, pp. 139 ss.). 
Este obra forma parte del acervo de la Biblioteca Jurídica Virtual del Instituto de Investigaciones Jurídicas de la UNAM www.juridicas.unam.mx

https://biblio.juridicas.unam.mx/bjv

sona, es ser constitución de sentido. Primero todavía que los valores políticos, morales y sociales, los derechos del hombre son comprendidos por lo que efectivamente estos son: vivas manifestaciones, en el sujeto, en cada sujeto, del principio del derecho. Es el derecho, instruido, finalmente, en su intrínseco potencial de universalidad relacional, el que nos provee efectivamente de la única llave a nuestra disposición para reivindicar y defender los derechos del hombre.

\section{LOS DEBERES DEL HOMBRE}

1. ¿Existen deberes fundamentales?

Fundamental Duties, deberes fundamentales, se titula un reciente coloquio de sabios. ${ }^{32}$ Los deberes fundamentales del hombre en la sociedad de los derechos: éste, uno de los temas del XIV Congreso de la Sociedad Italiana de Filosofía Jurídica y Política. ${ }^{33}$ Temas y títulos provocadores, indudablemente, en una época en la cual la reivindicación de los propios derechos precede, sin duda alguna, al reconocimiento de los propios deberes. Mazzini, escribiendo en 1860 Los deberes del hombre, ${ }^{34}$ estaba convencido de que la edad de los derechos (aquella inaugurada desde la Revolución francesa) fuera concluida y que se debería, decididamente, pasar a tematizar y a construir la nueva edad de los deberes. No obstante, el tratado de Mazzini es célebre, sobre todo por no ser leído. ${ }^{35}$

El problema, sin embargo, no es aquel de la anterioridad del deber al derecho o del derecho al deber. Considerados en el ámbito puramente lógico, es evidente que los dos conceptos se copertenecen y que cada uno reenvía por necesidad al otro. La teoría del derecho sabe bien que uno de los caracteres típicos de las normas es aquel imperativo-atributivo: atribuyendo a un sujeto un derecho, la norma implícitamente o explícitamente no puede no ordenar a otro sujeto cumplirlo, o de cualquier modo res-

32 Fundamental Duties, a cargo de D. Lasok, A. J. E. Jaffey, D. L. Perrott y C. Sachs, Oxford, 1980.

33 Las actas del Congreso fueron publicadas en el volumen Il problema del "metagiuridico" nell'esperienza contemporanea del diritto. I doveri fondamentali dell'uomo nella società dei diritti. Il diritto e alcune discipline di nuova frontiera, a cargo de R. Orecchia, Milán, 1984.

34 Publicado en el volumen LXIX de la edición nacional de los Scritti editi e inediti, Imola, 1935 (cfr. también Scritti politici, Torino, 1987).

35 En la misma dirección de Mazzini, se dirigía por la verdad, A. Comte (cfr. Système de politique positive, de 1851-1854, volumen I, París, 1912, p. 361). 
Este obra forma parte del acervo de la Biblioteca Jurídica Virtual del Instituto de Investigaciones Jurídicas de la UNAM www.juridicas.unam.mx

petarlo. Quien fuera destinatario de un deber, y no pudiera individualizar un sujeto en el cual cumplirlo, no sentiría cierto el gravamen. Y viceversa, quien fuera el titular de un derecho, pero no pudiera dirigirse a ningún sujeto en particular para verlo realizado, podría, con justo título, dudar de su competencia. Es esto, del resto, el motivo por el cual expresiones como aquella, celebérrima, del derecho a la felicidad (usada en la proclamación de Independencia de los Estados Unidos de América de 1776) no pueden tener un estrecho contenido jurídico: evocan competencias, pero no las concretizan porque no sabrían cómo hacerlo.

Pero, entonces, ¿tiene sentido para el jurista la pregunta si existen deberes fundamentales?, ¿no sería mejor reformularla y tratar juntos los derechos y los deberes fundamentales del hombre? La pregunta es seguramente fundada. Empero, considero que una reflexión sobre deberes fundamentales — que prescinda de aquella sobre derechos - pueda ser, de verdad, muy útil. Veamos por qué.

Esto que da lo esencial a la fórmula deberes fundamentales es —en mi personal punto de vista_-, la calificación de fundamental. Es sobre ésta sobre la que debemos dirigir nuestra atención. ¿En qué modo es posible determinar eso que es fundamental respecto de algo que no lo es? No es suficiente, evidentemente, identificar lo fundamental con lo relevante, sea, inclusive, con lo extremadamente importante. Si lo fundamental es tal, lo es no porque sea dotado de importancia (es verdad de hecho más bien lo contrario: es de verdad importante sólo lo que es fundamental), porque no tiene otro fundamento que sí mismo, porque no reposa ni reenvía a otro que lo constituya como tal. Cuando reflexionamos seriamente sobre eso que es fundamental, nos sentimos remitidos (nos guste o no) a la dimensión de lo absoluto, entendido (en sentido muy amplio y genérico) como eso que es sustraído de nuestra disponibilidad.

Podemos, por consiguiente, decir que va retenido un deber fundamental que grave a todos los hombres indiscriminadamente, y que, al mismo tiempo, sea tal, que ninguno pueda sustraerse de su cumplimiento. El deber fundamental es una deuda que no puede no ser pagada. Pero, ¿existen deudas semejantes?

\section{Cosas que nos enseñan los poetas}

Probablemente sí, y, de igual manera, probablemente seamos todos, íntimamente conocedores de ello. Sin embargo, nos perturba admitirlo, 
Este obra forma parte del acervo de la Biblioteca Jurídica Virtual del Instituto de Investigaciones Jurídicas de la UNAM www.juridicas.unam.mx

https://biblio.juridicas.unam.mx/bjv

así como nos perturba admitir la existencia de cualquier límite que sea para nosotros infranqueable. Pero cuando las defensas se relajan, cuando la sinceridad logra tener una preeminencia sobre el orgullo, la verdad logra, aunque lentamente, abrirse paso. Es la verdad y no otra cosa que la pura verdad, aquella que el príncipe Enrique, con un intraducible juego de palabras entre debt y death dice al tremebundo Falstaff en Enrique IV: Thou owest God a death (tienes con Dios una deuda de muerte). Y naturalmente, el príncipe obtiene de Falstaff una respuesta bufónica, que no niega, sin embargo, la veracidad del dicho. ${ }^{36}$

Demos otro ejemplo, y saltemos de una época, una cultura, una lengua a otras. Leamos en Alcestes de Eurípides, en el tercer episodio, aquel en el cual entra en una escena Eracles y penetra en la casa donde se llora la muerte de la ama. Eracles está un poco ebrio, no obstante, la embriaguez lo dota de sabiduría. Y al siervo que lo recibe, y que con el corazón lleno de tristeza lo mira con una hostilidad que se merecen los ebrios, el héroe dice amigablemente y con severidad:

\section{Ven acá}

que te haré más prudente. ¿Sabes cuál es la naturaleza de las cosas mortales? No, no lo sabes, creo, ¿y de quién habrías aprendido nada?

Y entonces, si no lo sabes, atiéndeme. Los mortales tienen una deuda, y esta es, que todos en absoluto deben morir. Y ninguno de los mortales sabe ciertamente si el día de mañana estará vivo... ${ }^{37}$

Todos los mortales tienen una deuda brotô̂s hápasi katthaneîn opheileítai. También en este acerto, como en el precedente, hay una término clave, el verbo opheilo, que indica el deber en la dimensión más propia, el deber que grava, sobre quien tiene una deuda, que es absolutamente pagada. Eurípides, así como Shakespeare. Y como tantos otros que han retomado y variado este nobilísimo topos.

Un topos literario, ciertamente noble, indudablemente; pero nada más. Así se podría pensar. Empero, también un topos que no se olvida: a

36 Shakespeare, W., Enrique IV, I parte, acto V, escena I.

37 Eurípides, Alcesti, pp. 779 y ss. Uso la espléndida traducción hecha por C. Diano, en el ensayo "La catarsi tragica", recuperado en C. Diano, Saggezza e poetica degli antichi, Vicenza, 1968, p. 236. 
Este obra forma parte del acervo de la Biblioteca Jurídica Virtual del Instituto de Investigaciones Jurídicas de la UNAM www.juridicas.unam.mx

(104

FRANCESCO D'AGOSTINO

su modo, esto es muy revelativo. Es claro que si lo sometemos a una lectura fría, iluminística, esto pierde todo su sabor: el hombre es un ser viviente, ¿qué cosa puede darse de extraño en su mortalidad?, ¿qué hombre puede creerse inmortal? También el sirviente en Alcestes, aquel al cual Eracles se dirige con severidad, lo sabe bien: no hay propiamente necesidad de que él venga a enseñárselo, con la gravedad de quien revela un secreto. Pero Eracles no se limita a decir una banalidad, es decir, que si muere; dice que se debe morir. Y que si debe morir, que sea ésta nuestra común y universal deuda, es menos obvio de cuanto no se acople sobre las primeras. La muerte, como mero hecho natural (como Müssen), se asocia a cualquier otro ser viviente; sin embargo, la muerte como deuda (como Sollen), hace de nosotros cualquier cosa que nos entrega como algo completamente diverso respecto a cualquier otro ser vivo. La muerte (Tod), es propia sólo del hombre, y no puede ser confundida con el fallecimiento (Ableben), el cual sorprende a los animales, observa profundamente Haidegger: ${ }^{38}$ el fallecimiento es un hecho; la muerte, un significado. Pero si lo es, lo es propiamente porque, siendo indudablemente un hecho (el más duro e irreductible de los hechos), no puede ser reducida en el simple plano de los hechos; propiamente porque le es inherente (en modo paradójico) la dimensión del deber. En la muerte, en conclusión, ser y deber ser, Sein y Sollen, coinciden; la muerte es un deber fundamental, porque en ésta es indiscutible la coincidencia entre eso que sobreviene como hecho (el accidente mortal) y eso que sobreviene como cumplimiento de una deuda (la muerte como prevista, esperada, temida, propuesta, experimentada; en conclusión, dotada de sentido). Los poetas todo esto lo han entendido, también cuando lo han esterilizado en un topos literario. Lo han entendido los teólogos, cuando toman en serio la promesa de la eternidad hecha por el Creador a la criatura, han negado que para el hombre la muerte vaya de acuerdo con un evento natural y la han por consecuencia tematizado como expiación de una culpa $;{ }^{39}$ muchos filósofos, en cambio, la han entendido menos afortunadamente, y desde Epicuro en adelante han buscado la reducción de la terribilidad del problema de la muerte; los pseudofilósofos probablemente, no la entenderán nunca.

38 Sein und Zeit, par. 52, tr. it., Essere e tempo, Milán, 1970, pp. 185 ss. Cfr. Ricci, M. T., "Heidegger e l'animale 'povero di mondo"”, en AA.VV., Filosofie dell'animalità, a cargo de E. Baccaarini, T. Cancrini y M. Perniola, Milán, 1992, p. 147.

39 Cfr. Pieper, J., Tod und Unsterblichkeit, München, 1979. 
Este obra forma parte del acervo de la Biblioteca Jurídica Virtual del Instituto de Investigaciones Jurídicas de la UNAM www.juridicas.unam.mx

https://biblio.juridicas.unam.mx/bjv

\section{Cómo hacer coincidir el ser con el deber ser}

Decir que en la muerte Sein y Sollen coinciden, significa caminar sobre el filo de la navaja y esforzar el lenguaje conceptual hasta deformarlo. No obstante, es claro, espero, que en este discurso no estemos trabajando sobre conceptos, sino sobre imágenes; y del resto una prospectiva que busca aferrarse a la realidad no limitándose a conceptuarla (y por consiguiente a abstraerla) y constreñida a trabajar también con metáforas. Buscamos otro modo de explicar esta dimensión de la fundamentalidad de la cual estamos a la búsqueda. Si hasta ahora hablamos de deberes fundamentales, veamos si un discurso análogo podría ser hecho para la categoría simétrica de los derechos fundamentales. Ahora, si el deber fundamental es aquello en el cual Sein y Sollen coinciden, también el derecho fundamental deberá ser clarificado en modo análogo: llamaremos, por consiguiente, fundamental aquel derecho que, inherente a tal punto al hombre, que - por más tentativas que se hagan en tal sentido- nunca pueda ser sustraído de aquel derecho que constituye el fundamento de una pretensión subjetiva tal, de no poder no ser en cualquier modo satisfecha (sin dejar nunca dejar de ser y permanecer como una pretensión). Aquí está el quid de profunda verdad del paradójico estoico sobre la libertad, que de una parte es vista como un derecho que el hombre justamente pretende que los otros le reconozcan (a nivel meramente ético, en la prospectiva clásica, a nivel ético y político en aquella moderna y contemporánea), pero que de otra parte es considerada una dimensión tan propia del ser del hombre que ninguno se la puede propiamente arrebatar. Pensemos en las célebres palabras de Plotino, sobre las cuales volvía, en la inminencia de la muerte, en la Hipona asediada por vándalos, el viejo San Agustín: Non erit magnus magnum putaans quod cadunt ligna el lapides, et muriuntur mortales. ${ }^{40}$ ¿Quién o qué cosa nunca podrán destruir al sabio su serenidad, su libertad de espíritu? Los ejemplos que ofrecía Plotino son para nuestra sensibilidad intolerables: ni la muerte de la mujer, ni la caída en esclavitud de los hijos, ni el estupro de las hijas, ni con mayor razón alguna cosa que pueda golpearlo en la propia persona por cuanto trágica, injusta, violenta, puede destruir al hombre — si él mismo no desea hacercelo desposeer - la serenidad dada de la propia libertad interior: ésta es absolutamente y constitutivamente suya. Sin embargo, no lo es en

40 Possidio, Vita Augustini, 28. 11. "No será sabio quien juzgará de gran cosa eso que hecho de madera y de piedra sea destruido, y que los mortales mueran", la referencia es a Enneadi, I. 4. 7. 
Este obra forma parte del acervo de la Biblioteca Jurídica Virtual del Instituto de Investigaciones Jurídicas de la UNAM www.juridicas.unam.mx

el sentido que sea una cualidad fisiológica y casi inadvertible cualidad de ser humano, tanto poco banal es la libertad, que justamente Hegel subrayaba que propiamente porque el espíritu libre es el espíritu real, ninguna otra idea tiene una fuerza tan indomable y sea tan capaz — una vez que se adquiera conciencia - de arrastrar a los hombres... ${ }^{41}$ Aquellos que reivindican la libertad, que combaten por ella, mueren por ella, la ponen como valor supremo y fundamental, propiamente en este doble sentido, que ella es el presupuesto y junto el objetivo de cada praxis humana; el punto de partida (esto que me hace identificar al hombre en cuanto hombre) y el punto de arribo (eso que el hombre para alcanzar su plenitud debe allegarse). En conclusión, en la libertad Sein y Sollen coinciden: la libertad es el derecho fundamental propiamente porque absoluta e inexpropiable, $\mathrm{y}$ al mismo tiempo absolutamente reivindicable.

\section{El deber ser}

Si este discurso tiene sentido, es posible ahora decir cualquier cosa más precisa sobre el deber fundamental como deber jurídico. Un deber jurídico fundamental debe ser tal que en esto, según la prospectiva recién expuesta, Sein y Sollen coincidan; debe es decir, poder superar la antinomia divisionista entre un "ser sin deber" y un "deber sin ser"; puede, por lo tanto, dar esencia a aquel deber de ser, en el cual Cotta por años dedica su atención. ${ }^{42}$ La coexistencia puede verdaderamente ser expresada como el deber fundamental (o, si se desea, el fundamento del derecho) porque en ésta se reproduce la dinámica que busqué describir; el hecho de coexistir deviene para el hombre el deber de reconocerse a sí y los demás como coexistentes, y el deber de coexistir presupone la no eliminación del hecho que siempre y de cualquier modo, nosotros los hombres seamos ya coexistentes. El deber de coexistir es fundamental, porque abstraerse de la coexistencia no es posible (significaría abstraerse del estado de ser humano) y porque, por otra parte, la coexistencia es un estado en el cual no se debe entrar, porque se está ya.

41 Hegel, G. W. F., Enciclopedia delle scienze filosofiche in compendio, par. 482, tr. it., Bari, 1967, vol. II, p. 442.

42 Cfr. Cotta, S., Il diritto nell'isistenza. Linee di ontofenomenologia giuridica, Milán, 1991, p. 96. De Cotta, $c f r$. también "La coesistenza come fondamento ontologico del diritto", ahora en S. Cotta, Giustificazione e obbligatorietà delle norme, Milán, 1981, pp. 137-152. 


\section{DERECHO Y DERECHOS HUMANOS. INTRODUCCIÓN A UN PROBLEMA*}

Joaquín GARCÍA-HUIDOBRO

SUMARIO: I. ¿Qué significa ser titular de un derecho. II.¿Qué entendemos por derechos humanos? III. Valor del acuerdo práctico.

Las discusiones filosóficas en torno a los derechos humanos se refieren, por una parte, a su validez como lenguaje jurídico y, por otra, a su naturaleza y fundamentación. En las páginas que siguen se recogen unas reflexiones a propósito del sentido de la expresión 'derechos humanos' (I y II) y de los límites de los acuerdos prácticos que están en la base de las diversas declaraciones de derechos (III). El clarificar lo que significa 'derechos humanos' puede dar algunas luces acerca de la validez de utilizar esta categoría en el lenguaje del derecho. Por otra parte, la cuestión de los acuerdos prácticos en esta materia se relaciona con la posibilidad, esbozada por algunos, de superar la difícil pregunta por el fundamento de los derechos.

\section{I. ¿QUÉ SIGNIFICA SER TITULAR DE UN DERECHO?}

Una de las características del pensamiento jurídico de la Modernidad es la extensión que experimenta en él la noción de derecho subjetivo. ${ }^{1}$ Expresiones como 'derecho a la vida', 'derecho de expresión' o 'derecho de propiedad' han tomado carta de ciudadanía en el vocabulario jurídico, en especial a partir del siglo XVIII. Aunque la voz 'derecho' no significa exactamente lo mismo en los ejemplos citados, cabe reconocer en todos

* Este trabajo forma parte de un proyecto más amplio, patrocinado por la Dirección de Investigación de la Universidad de Valparaíso. El autor agradece las observaciones de los profesores C. Orrego, J. I. Martínez y M. Núñez.

1 Tuck, R., Natural Rights Theories. Their Origin and Development, Cambridge, Cambridge University Press, 1979, p. 13. 
Este obra forma parte del acervo de la Biblioteca Jurídica Virtual del Instituto de Investigaciones Jurídicas de la UNAM www.juridicas.unam.mx

https://biblio.juridicas.unam.mx/bjv

108

JOAQUÍN GARCÍA-HUIDOBRO

ellos una idea subyacente: la de poder. Tener un derecho parece lo mismo que tener un poder, pero no de cualquier naturaleza, pues no se trata de un poder físico sino moral. Que el derecho sea un poder significa que es una facultad que nosotros tenemos, cuyo ejercicio depende normalmente de nuestra voluntad. Pero que este poder sea moral significa que no se identifica con nuestra capacidad física: no todo aquello que podemos físicamente realizar puede calificarse como derecho. En este sentido, la identificación entre derecho y poder es sólo parcial, a diferencia de lo que pensaba Hobbes. Para este autor inglés, en el estado de naturaleza las nociones de poder y derecho son sinónimas. ${ }^{2}$ El derecho no sería más que la libertad de hacer lo que se quiera. Si esto es así, no debe mover a extrañeza que los hombres quieran salir de la inseguridad del estado de naturaleza y pasar al estado social. ${ }^{3}$

Al decir, en cambio, que el derecho es un poder moral, estamos suponiendo que nuestra libertad no es infinita, que estamos limitados, que hay cosas que podemos (moralmente) hacer y otras que no, aunque estén al alcance de nuestras manos y tengamos la fuerza para realizarlas. No sucede lo mismo con los animales: ellos no viven en este doble orden, de lo física y de lo moralmente posible. Su vida es más sencilla: ellos reaccionan de manera necesaria ante ciertos estímulos, a menos que entre en escena otro estímulo más fuerte, que atenúe o anule al anterior. De ahí que los animales carezcan de la experiencia del remordimiento.

La difusión del lenguaje de los derechos hace que hoy expliquemos muchas veces los conflictos morales en términos de derechos. Sostenemos que es injusto aquel trato que lesiona nuestros derechos, por ejemplo, el derecho a ser oídos. Decir que un comportamiento lesiona nuestros derechos es lo mismo que decir que es injusto, o sea que no está amparado por un criterio de legitimidad: que el agresor dispone de un poder que en realidad no es un poder moral, sino meramente físico. Ha lesionado nuestros derechos porque su actuación no se funda en un título jurídico, carece de legitimidad. Para que un poder o facultad, entonces, pueda ser considerado como derecho, debe estar respaldado por un título: yo puedo exigir la entrega de la cosa que compré porque estoy amparado por el contrato que sobre ella he celebrado, puedo presentarme como candidato en unas elecciones — cumplidos ciertos requisitos - porque la ley me lo permite. Así, el contrato y la ley son títulos en los que se fundamentan cier- 
Este obra forma parte del acervo de la Biblioteca Jurídica Virtual del Instituto de Investigaciones Jurídicas de la UNAM www.juridicas.unam.mx

https://biblio.juridicas.unam.mx/bjv

DERECHO Y DERECHOS HUMANOS

tos derechos. Otros títulos son las sentencias judiciales, o la costumbre. Tradicionalmente se ha admitido que además de los títulos positivos hay otros de carácter natural, que también dan origen a ciertos derechos. Sin embargo, como se sabe, esta es una materia que ha sido objeto de numerosos debates.

\section{II. ¿QUÉ ENTENDEMOS POR DERECHOS HUMANOS?}

A veces se dice que la expresión 'derechos humanos' constituye un pleonasmo. Si el derecho existe por causa del hombre, ¿cómo podría haber derechos que no fuesen humanos?, ¿usamos esa expresión para distinguirlos de unos supuestos derechos divinos? No parece que sea ése el origen de nuestra locución. ¿Será entonces a causa de los llamados derechos de los animales? Hoy se discute mucho sobre el tema, pero en todo caso tampoco parece que la posibilidad de unos derechos de los animales haya estado en la mente de los primeros que hablaron de derechos del hombre o, más contemporáneamente, de derechos humanos. Es evidente que con la expresión 'derechos humanos' se quiere hacer algún tipo de referencia al hombre. Ya en la Declaración de derechos hecha por el buen pueblo de Virginia (1776) se decía que "todos los hombres son por naturaleza igualmente libres e independientes y tienen ciertos derechos innatos", y en la Declaración francesa de 1789 se habla de unos "derechos naturales, inalienables y sagrados del hombre", ideas que, con diversas terminologías, se repiten en otros textos modernos y contemporáneos.

Quizá una ayuda para clarificar este concepto de derechos humanos sea ver a qué otro concepto se opone. Aquí parece no haber grandes dudas: cuando decimos derechos humanos los estamos distinguiendo de los derechos positivos, ${ }^{4}$ es decir, de aquellos derechos que tenemos porque el Estado o la comunidad nos los han asignado, normalmente a través de la ley o la costumbre. Lo dicho no significa que los derechos humanos no puedan o deban ser positivados. Desde el siglo XVIII se ha intentado hacerlo en distintos documentos, pero todos ellos recalcan la idea de que se trata de derechos innatos, cuya existencia es anterior a los documentos e

4 Massini, C. I., "Derechos humanos 'débiles' y derechos humanos absolutos", en idem, Manual de filosofía del derecho, Buenos Aires, Abeledo-Perrot, 1995, pp. 249-265. Sobre la anterioridad o preexistencia de los derechos humanos a la legalidad positiva: J. Hervada, "Problemas que una nota esencial de los derechos humanos plantea a la filosofía del derecho", en C. I. Massini (ed.), El iusnaturalismo actual, Buenos Aires, Abeledo-Perrot, 1996, pp. 109-124. 
Este obra forma parte del acervo de la Biblioteca Jurídica Virtual del Instituto de Investigaciones Jurídicas de la UNAM www.juridicas.unam.mx

https://biblio.juridicas.unam.mx/bjv

incluso al Estado mismo. A. C. Pereira ha puesto en relieve la aparente paradoja de que, según el constitucionalismo clásico, una característica de los derechos constitucionales es la de ser preconstitucionales. ${ }^{5}$ Los derechos del hombre son recogidos en una Constitución - por eso se pueden llamar constitucionales - pero no son creados por ella. Son derechos, según se dice en esas declaraciones, que pertenecen al hombre por ser quien es y no en virtud de ciertos hechos propios o ajenos, o de condiciones posteriores, como puede ser la nacionalidad, las preferencias políticas o la religión del individuo. ${ }^{6}$ Y precisamente en su carácter suprapositivo reside - como veremos - la capacidad de los derechos humanos de servir como criterio de evaluación a los diversos regímenes jurídico-políticos. En efecto, frente a ellos no cabe justificar su desconocimiento o violación aduciendo tradiciones locales, una determinada identidad nacional o los intereses del grupo dominante. Detrás de la idea de unos derechos humanos está el que hay ciertas cosas o atributos que corresponden a todo individuo de la especie humana, y ciertos modos de ser tratado que no son dignos de él. Así, los derechos humanos no serían más que la expresión jurídica y política de la dignidad humana, y ella — como sabemos - no se posee por lo que se haya hecho o se tenga, sino por lo que se es: hombre.

Pero, si se afirma que los derechos humanos son derechos suprapositivos, ¿no se los estará asimilando excesivamente a la vieja categoría del derecho natural, que tan discutida ha resultado en nuestro siglo? ¿No se los hace patrimonio de una determinada filosofía jurídica que, aunque antigua y respetable, dista de suscitar el consenso que requiere algo tan importante como los derechos humanos? El tema de la vinculación entre derechos humanos y derecho natural es en parte inevitable, al menos desde la perspectiva histórica. ${ }^{7}$ En efecto, los derechos humanos como categoría jurídica son una elaboración de una particular versión del iusnaturalismo que se difundió en Europa especialmente a partir del siglo XVIII, aunque sus antecedentes son anteriores. Pero esto nos lleva a una curiosa paradoja, porque si se concibe a los derechos humanos como derechos

5 Pereira, A. C., Lecciones de teoría constitucional, Madrid, Edersa, 1987, p. 289; Wald, B., "Naturrecht und Menschenrechte. Einleitende Bemerkungen zu einem Dialog der Philosophen", en F. Inciarte, B. Wald (eds.), Menschenrechte und Entwicklung: im Dialog mit Lateinamerika, Vervuert Verlag, Frankfurt am Main, 1992, pp. 9-19.

6 Cfr. Declaración de derechos de Virginia, sec 1; Declaración de los Derechos del Hombre y del Ciudadano, Preámbulo; también los artículos 1 y 2; Declaración Universal de los Derechos Humanos, Preámbulo, también los artículos 1 y 2.

7 Cfr. Pereira, A. C., Lecciones..., pp. 285-333. 
Este obra forma parte del acervo de la Biblioteca Jurídica Virtual del Instituto de Investigaciones Jurídicas de la UNAM www.juridicas.unam.mx

https://biblio.juridicas.unam.mx/bjv

naturales, entonces deberían ser universales y, ¿cómo acabamos de decir que la teoría de los derechos humanos es el fruto del pensamiento jurídico moderno? En efecto, diversos autores han puesto en relieve que la teoría de los derechos naturales o del hombre no sólo no es central, sino que incluso es desconocida en el pensamiento premoderno. ${ }^{8}$ Éste, como se sabe, se construye más sobre la noción de bien y de obligación que sobre la noción de derecho entendido como facultad. El derecho es comprendido o como ley (acepción normativa) o como aquella parte de las cargas y beneficios que corresponden a cada uno en la vida social (acepción objetiva). En este sentido, el derecho en la perspectiva premoderna es siempre algo limitado (de ahí las críticas que autores como Burke hacen al lenguaje, menos definido y preciso, de los derechos del hombre). ${ }^{9}$

Es así como, en la medida en que se profundiza en la teoría moderna de los derechos del hombre, se ve que su gestación sería impensable sin los autores del llamado iusnaturalismo racionalista, pero —al mismo tiempo- la noción de unos derechos subjetivos naturales no es clásica, sino que constituye un aporte de la modernidad, es decir, del giro antropológico que la teoría jurídica y política experimenta a partir del Renacimiento. ${ }^{10}$ Este aporte no ha sido recibido pacíficamente y su aceptación generalizada no se produjo en las cátedras y bibliotecas universitarias sino en la praxis política de la humanidad, especialmente después de la segunda gran guerra y las experiencias totalitarias. ${ }^{11}$ En efecto, una cosa es preocuparse por el respeto y promoción de la dignidad humana y otros bienes fundamentales y otra muy distinta (al menos desde una perspectiva

$8 \mathrm{Al}$ menos en el mundo romano: $c f r$. D’Ors, Á., “Aspectos objetivos y subjetivos del ius”, en idem, Nuevos papeles del oficio universitario, Madrid, Rialp, 1980, p. 283. Para la discusión acerca de la admisibilidad del derecho subjetivo en el aristotelismo medieval: Massini, C. I., "El derecho subjetivo: ¿realidad universal o histórica? Consideraciones a partir de un texto de Michel Villey", en idem, El derecho, los derechos humanos y el valor del derecho, Buenos Aires, Abeledo-Perrot, 1987, pp. 41-70.

9 Cfr. Villey, M., "La filosofía del derecho de Burke y su crítica a los 'derechos del hombre"”, en AA. VV., Los derechos humanos, Mendoza, Idearium, 1985; un panorama general en: Rabbi-Baldi, R., La filosofía jurídica de Michel Villey, Pamplona, Eunsa, 1990, cap. X; A. Guzmán, "Sobre la naturaleza de la teoría de los derechos del hombre", Revista de Derecho Público, núm. 42, 1987, pp. 77-93.

10 Sobre la posibilidad de compaginar la tradición clásica y la moderna a propósito de los derechos subjetivos hay una amplia bibliografía en los últimos años. Recientemente: Beuchot, M., Derechos humanos, iuspositivismo y iusnaturalismo, México, UNAM, 1995, pp. 153-167, y Saldaña, J., "Críticas en torno del derecho subjetivo como concepto de los derechos humanos", Boletín Mexicano de Derecho Comparado, núm. 86, 1996, pp. 685-706.

11 Cfr. Kühnhardt, L., Die Universalität der Menschenrechte, Bundeszentrale für politische Bildung, Bonn, 1987, pp. 86-104. 
Este obra forma parte del acervo de la Biblioteca Jurídica Virtual del Instituto de Investigaciones Jurídicas de la UNAM www.juridicas.unam.mx

https://biblio.juridicas.unam.mx/bjv

histórica) es expresar dicha preocupación dentro de una determinada teoría y lenguaje como es el de los derechos del hombre. De no tenerlo en cuenta se incurrirá en el error de pensar que la conciencia de la dignidad humana nace con el constitucionalismo o, lo que también es erróneo, que aquellos autores que como Ross, Villey y otros critican el lenguaje de los derechos humanos por pensar que no se ajusta al método y uso del derecho son individuos insensibles a los atropellos o que justifican las lesiones a la dignidad de las personas. El hecho de que las experiencias sufridas por la humanidad en el siglo XX hayan dado una enorme difusión a la teoría y lenguajes de los derechos humanos no significa que esta sea la única forma posible en que el derecho puede enfrentar la delicada cuestión de la protección de las personas. ${ }^{12}$

\section{VALOR DEL ACUERDO PRÁCTICO}

Muchas veces se ha señalado lo notable que resulta que en 1948 se haya logrado un acuerdo prácticamente generalizado acerca del texto de la Declaración de Derechos Humanos de la ONU, no obstante que sus redactores y signatarios pertenecían a sistemas filosóficos muy diferentes e incluso contrapuestos. Esto se debió en parte a que los participantes - precisamente teniendo en cuenta esas diferencias - tuvieron muy claro que se trataba de lograr un acuerdo práctico. ${ }^{13}$ Así, hoy parece universalmente aceptado que existan límites al poder y que esos límites están expresados en los derechos humanos. Pero ¿por qué hay que respetar los derechos humanos?, ¿por qué se tienen los derechos humanos? Aquí las respuestas son muy diversas.

Alguno podría pensar que la diferencia de respuestas acerca del fundamento de los derechos humanos hace ocioso el plantearse el problema - cuando no es una tarea condenada al fracaso- máxime cuando ya tenemos ese acuerdo práctico. ${ }^{14}$ Lo importante sería coincidir en el qué, no

12 Un buen ejemplo de esta diferencia: B. Bravo, Poder y respeto a las personas en Iberoamérica. Siglos XVI a XX, Valparaíso, Ediciones Universitarias de Valparaíso, 1989, y los textos de A. Guzmán antes citados.

13 Cabría discutir acerca de la practicidad de este acuerdo: en algunos casos los textos de derechos humanos establecen normas positivas (como cuando se acuerda abolir la pena de muerte) y tienen, por tanto, una índole práctica. Pero no siempre sucede lo mismo: en otros casos el acuerdo sigue teniendo una carácter teórico.

14 Sobre esta discusión: García-Huidobro, J., Defensa y rescate de los derechos humanos, Valparaíso, Edeval, 1987. 
Este obra forma parte del acervo de la Biblioteca Jurídica Virtual del Instituto de Investigaciones Jurídicas de la UNAM www.juridicas.unam.mx

https://biblio.juridicas.unam.mx/bjv

en el porqué (esto ya lo decía Aristóteles a propósito de las materias prácticas, en donde la experiencia vale más que los libros). ${ }^{15}$ Pero: ¿es tan efectivo que sea irrelevante para la práctica la cuestión del porqué? Un primer hecho evidente es que el porqué —es decir, el tener alguna fundamentación a nuestra preocupación por los derechos - contribuye a consolidar una voluntad de respeto de los derechos humanos. Pero también hay razones de tipo jurídico y político, relacionadas con los complejos problemas de interpretación que acarrean los textos de derechos humanos y el no menos complejo problema de la colisión de derechos ${ }^{16}$ y del discernimiento entre lo que auténticamente constituye un derecho humano, una exigencia de la dignidad humana, y lo que es meramente una expectativa, muchas veces ilegítima. Todo esto lleva a reconocer que en materias de interpretación y aplicación de los derechos humanos no existe una neutralidad, y muchas veces se ha destacado que las pretensiones de neutralidad no son más que máscaras ideológicas que ocultan intereses o relaciones de poder.

El disponer de una determinada idea del bien humano ayuda a resolver los conflictos de derechos, ${ }^{17}$ que de otro modo serían insolubles o quedarían entregados a soluciones de fuerza más o menos encubiertas (aquí habría que analizar la importancia de las visiones del hombre en la interpretación y aplicación de los derechos, materia que no podemos tratar en este lugar). Si a esto se suma la referencia implicada en el caso concreto tendremos que el juez dispone de muchos más elementos para decidir un conflicto de lo que se podría pensar tras el solo examen de los derechos contrapuestos (ejemplo: igualdad-libertad). Es necesario recordar — como se ha señalado— ${ }^{18}$ que los conceptos, por ejemplo aquellos recogidos en las declaraciones, vistos en abstracto siempre se presentan como opuestos e, incluso, tomados por sí solos, como irreconciliables. Esto también ayuda a entender el problema de la limitación de los dere-

15 Met. I, 1, 981 a 24-981 b 9; I, 2, 983 a 11 ss.

16 No todos están de acuerdo en que existan colisiones de derechos. Cabe pensar, con Ignacio del Otto, que 'los derechos amparan lo que amparan y no otra cosa'. Con ello se quiere decir que todo derecho tiene límites y que éstos los descubre el intérprete ("La regulación del ejercicio de los derechos y libertades. La garantía de su contenido esencial en el artículo 53.1 de la Constitución", en M. Retortillo e I. del Otto, Derechos fundamentales y Constitución, Madrid, Civitas, 1988). Así, la libertad de expresión no ampara, por no ser parte de su contenido, las injurias y calumnias.

17 Finnis, J., "Menschenrechte und die letzte Begründung des Rechtes", en J. Finnis et alii, Recht auf Gerechtigkeit, Colonia, Adamas Verlag, 1979, pp. 55-88.

18 Cfr. Serna, P., Positivismo conceptual y fundamentación de los derechos humanos, Pamplona, Eunsa. 
Este obra forma parte del acervo de la Biblioteca Jurídica Virtual del Instituto de Investigaciones Jurídicas de la UNAM www.juridicas.unam.mx

https://biblio.juridicas.unam.mx/bjv

chos humanos, que parecen difícilmente conciliables con el carácter de absoluto que se les asigna. Absoluto, tratándose de los derechos humanos, no significa ilimitado, sino sólo que la titularidad de los mismos no está sujeta a condiciones de utilidad. ${ }^{19}$ Sí está limitado, en cambio, todo derecho por su propia finalidad, más allá de la cual su uso caprichoso desemboca en el abuso del derecho. ${ }^{20}$ Por otra parte, cuando se sujeta el ejercicio de ciertos derechos a criterios o márgenes de orden público tampoco significa propiamente que se los está restringiendo, sino más bien que se está asegurando que no se viole el sentido moral de cada derecho humano (su referencia a la persona), es decir, que no se tomará pretexto de los derechos para lesionar la dignidad propia y ajena. ${ }^{21}$

Lo dicho nos lleva a una conclusión importante: los principios de derechos humanos, tal como se recogen en los diversos textos internacionales, constituyen directrices de acción, criterios de legitimidad y reglas de solución de conflictos, que parecen razonables a hombres de muy diversa procedencia. Sin embargo, muchas veces los conflictos de derechos o las dificultades acerca de la extensión de un derecho sólo pueden solucionarse teniendo una determinada concepción del hombre y esa concepción del hombre dista de ser neutral. Uno de los ejemplos más claros es en la actualidad la discusión en torno al aborto, que si bien se plantea muchas veces como una colisión de derechos (derecho a la vida del que está por nacer vs. derecho de la madre a disponer del propio cuerpo), sucede que sólo podrá resolverse acudiendo a una determinada idea de lo que es el hombre, desde cuándo se es hombre, qué se considera cuerpo humano, cuáles son las relaciones de una persona con su propio cuerpo, qué es lo legalmente exigible en una sociedad democrática, qué significa que una persona tenga poder de disponer sobre algo, si realmente existen colisiones de derechos, etcétera. En estas materias es imposible ser neutral, y aunque todos estamos de acuerdo en que todos los hombres tienen derecho a la vida y que todos los hombres tienen derecho a la libertad, no

19 Así, dice John Finnis que "it is always unreasonable to choose directly against any basic value, whether in oneself or in one's fellow human beings. And the basic values are not mere abstractions; they are aspects of the real well-being of flesh-and-blood individuals. Correlative to the exceptionless duties entailed by this requirements are, therefore, exceptionless or absolute human claimrights most obviously, the right not to have ones life taken directly as a means to any further end" (Natural Law and Natural Rights, Oxford, Oxford University Press, 1980, p. 225).

20 La teoría del abuso del derecho nace precisamente para hacer práctico el carácter limitado de los derechos abstractos.

21 Una explicación acerca del carácter absoluto de los derechos no obstante la admisión de límites a los mismos: Pereira, A. C., Lecciones..., pp. 293 y ss. 
Este obra forma parte del acervo de la Biblioteca Jurídica Virtual del Instituto de Investigaciones Jurídicas de la UNAM www.juridicas.unam.mx

https://biblio.juridicas.unam.mx/bjv

todos estamos de acuerdo en la solución del problema del aborto, por la sencilla razón de que nuestras antropologías son muy diferentes, lo que nos lleva a llenar las fórmulas jurídicas de contenidos muy diversos.

Si no se tiene presente que en estas materias sólo parcialmente cabe la neutralidad se caerá en un optimismo que, al estar poco fundamentado en los aspectos metodológicos de interpretación del derecho, podrá ser utilizado fácilmente con fines ideológicos. ${ }^{22}$ Así, se dirá que "la teoría de los derechos humanos permite o prohíbe tal cosa", en vez de decir: "la teoría de los derechos humanos, entendida a la luz de mi particular concepción del bien humano, etcétera.". ${ }^{23}$ Esta posibilidad de uso ideológico ya fue advertida por los primeros críticos de la Declaración Francesa de los Derechos del Hombre y del Ciudadano, ${ }^{24}$ como E. Burke y K. Marx, quienes sostuvieron que lo que se estaba proclamando no eran los derechos del hombre sino los del burgués. Resulta entonces que los derechos humanos, que deberían ser principios que contribuyan a la protección del débil, pueden pasar a ser un instrumento más de dominación, en la medida en que los más fuertes puedan presentar sus intereses particulares como si pertenecieran a la humanidad como tal. Esto, evidentemente, es un uso ideológico. ¿Significa, entonces, como sostienen algunos críticos contemporáneos de la teoría de los derechos humanos, que necesariamente la idea de derechos humanos está ideológicamente contaminada y no es más que un subterfugio para defender ya sea el estado de cosas vigente ya la necesidad de su cambio? ¿Significa también que la relevancia del elemento antropológico en la lectura de los textos de derechos humanos hace ilusorio el acuerdo práctico al que ha llegado la humanidad después de tantos esfuerzos y sufrimientos? Las dos preguntas están estrechamente conectadas, pero quizá sea conveniente partir por esclarecer la segunda.

Cuando decimos que en muchos casos no se puede llegar a una solución práctica sin acudir a criterios antropológicos, lo que estamos haciendo es llamar la atención acerca del peligro que lleva una actitud ingenua en la materia. Sin embargo, cabe indicar que, afortunadamente, no todos

22 Cfr. Finnis, J., Natural..., pp. 3-22.

23 La única posibilidad de salir de este perspectivismo es pensar, como lo hace la tradición filosófica clásica, que cabe hacer coincidir la propia visión de las cosas con la verdad universal objetiva. Pero esta salida está vedada a los autores que adscriben a la neutralidad axiológica del derecho, ya que ellos normalmente no suscriben la idea de una ética objetiva.

24 En todo caso, esta posibilidad está presente siempre en el derecho, no parece ser un problema exclusivo de las declaraciones, si bien — por su génesis y contenido— ellas están particularmente expuestas a sufrirlo. 
Este obra forma parte del acervo de la Biblioteca Jurídica Virtual del Instituto de Investigaciones Jurídicas de la UNAM www.juridicas.unam.mx

https://biblio.juridicas.unam.mx/bjv

los casos son tan complejos ni dramáticos como los del aborto, y que para resolver el resto de los casos sí puede ser útil el disponer de un acuerdo práctico. Normas como el artículo 2 de la Convención para Reducir los Casos de Apatridia, ${ }^{25}$ que dice que "salvo prueba en contrario se presume que un expósito que ha sido hallado en el territorio de un Estado contratante ha nacido en ese territorio, de padres que poseen la nacionalidad de dicho Estado", pueden ser aplicadas, hasta donde se alcanza a ver, sin tener que desentrañar antes complicadas cuestiones acerca de la índole del ser humano o el ámbito de su libertad. En este terreno, el acuerdo práctico se revela de gran utilidad. ¿Cuán amplio es ese campo en el cual cabe resolver problemas acudiendo sólo a la aplicación de principios consensuales a las circunstancias de hecho? Probablemente es un poco menos amplio de lo que pensaban los redactores de la Declaración de $1948 .{ }^{26}$

De todos modos, aun en aquellos casos en donde intervienen cuestiones de valores a la hora de interpretar las normas de derechos humanos, es útil contar con textos y documentos de aceptación general, pues constituyen un punto de partida para mostrar, por ejemplo, que la interpretación que uno propone de un precepto determinado tiene la ventaja de armonizar mejor con otros preceptos que de otro modo quedarían sin aplicación o carecerían de sentido. Aquí, sin embargo, la tarea de aplicar los principios a un caso particular no será de índole deductiva, como pensaban seguramente los redactores de las primeras declaraciones de derechos, sino tópica. Pero, aunque no logremos una completa exactitud en nuestros razonamientos, sin embargo podemos decir que las soluciones que hayamos conseguido serán respuestas razonables ante el caso que se presenta.

Si esto es así, entonces resulta claro que la función ideológica de las declaraciones de derechos no será tal, o, mejor dicho, sólo tendrá lugar allí en donde se pretenda aplicar los principios establecidos prescindiendo de los problemas éticos y antropológicos que están implicados en su comprensión. Si alguien pensaba que la elaboración de declaraciones hacía

25 Adoptada el 30 de agosto de 1961 por una conferencia de plenipotenciarios, en cumplimiento de la resolución 896 (IX), de 4 de diciembre de 1954, tomada por la Asamblea General de la ONU, en Hervada-J., J. y Zumaquero, M., Textos internacionales de derechos humanos, Pamplona, Eunsa, 1978, pp. 369-379.

26 Ya alguno de los que participaron mostró que el optimismo inicial debía ser moderado por la relevancia que adquieren cuestiones filosóficas en la solución de problemas prácticos (J. Maritain hace algunas observaciones al respecto, en El campesino del Garona, Bilbao, Desclée de Brouwer, 1967, pp. 103-108) 
Este obra forma parte del acervo de la Biblioteca Jurídica Virtual del Instituto de Investigaciones Jurídicas de la UNAM www.juridicas.unam.mx

https://biblio.juridicas.unam.mx/bjv

innecesario el debate de las ideas para la solución de las disputas existentes en la sociedad, esa persona evidentemente experimentará una desilusión. Pero como se trataba de una ilusión peligrosa, no debemos tener miedo de perderla.

Decía Norberto Bobbio ${ }^{27}$ que, una vez elaboradas las declaraciones, la tarea fundamental consistía en perfeccionar las garantías, que permitan que esos derechos sean efectivos y no queden reducidos a meras aspiraciones. No cabe duda que esa es una tarea muy importante, en la que la tradición británica y la tradición hispánica tienen una indudable ventaja sobre la francesa de $1789 .{ }^{28}$ Sin embargo, hoy resulta imprescindible un esfuerzo por volver a las preguntas de siempre e intentar arrojar luces sobre lo que es el hombre, pues en la medida en que lo comprendamos podremos trazar mejor la frontera entre lo humano y lo inhumano en las relaciones sociales.

27 "Presente y futuro de los derechos humanos", Anuario de Derechos Humanos, 1987, pp. 7-28.

28 Bravo, B., Poder..., pp. 35-68. Como lo ha mostrado ese autor, no faltaron juristas notables en América durante el periodo indiano. Sobre esta interesante materia véase su: "La literatura jurídica indiana del barroco", Revista de Estudios Histórico-Jurídicos, núm. 10, 1985, y otros trabajos contenidos en: idem, Derecho común y derecho propio en el Nuevo Mundo, Santiago, Editorial Jurídica, 1989, en donde se muestra el uso que de la tópica jurídica hacen estos autores. También resulta ilustrativo: Salinas, C., "El iusnaturalismo hispano-indiano y la protección jurídica de la persona", Anuario Mexicano de Historia del Derecho, núm. VI, 1994, pp. 219-237, y Köck, H. F., Der Beitrag der Schule von Salamanca zur Entwicklung der Lehre von den Grundrechten, Berlín, Duncker \& Humblot, 1987, pp. 15 y ss. 


\section{LOS DERECHOS HUMANOS EN LA LUCHA POLÍTICA}

\section{Montserrat HERRERO}

SUMARIO: I. Introducción. II. Los derechos humanos y sus ambigüedades. III. Los derechos humanos como título de intervención. IV. El conflicto de dos órdenes políticos: universalismo y particularismo. V. Bibliografía.

\section{INTRODUCCIÓN}

Como señalaba Juan Pablo II en el discurso ante la Asamblea General de las Naciones Unidas en octubre de 1995, ninguna época como la nuestra, el siglo XX, ha tomado tanta conciencia de lo que significa el ser humano y de sus derechos. Parece que el creciente interés por la protección de estos derechos por parte de todas las naciones del mundo viene a ser la gran ganancia que ha aportado el siglo que ahora termina, un siglo que - como ya es un tópico señalar- ha sido verdaderamente sangriento y ha revelado al hombre la cantidad de mal de que es capaz.

Parece, por tanto, que gracias a la formulación y ratificación de estos derechos por parte de la mayor parte de las naciones del mundo se ha logrado un progreso humano que era necesario como contrapunto del progreso científico y técnico; el cual, por su veloz desarrollo, había casi abrumado a la humanidad corriendo delante de ella hasta el punto de dominarla.

Se espera de ellos que defiendan al hombre de los hombres o, más bien, lo humano de los hombres. Están formulados en un ambiente esencialista, ${ }^{1}$ aunque su positivización y promulgación para el ámbito universal sin duda depende de un momento histórico concreto del cual no se pueden desligar sin que pierdan todo su sentido: la victoria de Estados Unidos, Inglaterra y Francia en la Segunda Guerra Mundial.

1 Possenti, V., p. 269. Habla de la filosofía "esenciocéntrica" de la que se nutren los derechos humanos. 
Este obra forma parte del acervo de la Biblioteca Jurídica Virtual del Instituto de Investigaciones Jurídicas de la UNAM www.juridicas.unam.mx

https://biblio.juridicas.unam.mx/bjv

Ante esa pretensión de defensa de lo humano se abre siempre la pregunta por qué es lo humano. Y, consiguientemente, la cuestión acerca de quién puede arrogarse la facultad de interpretarlo. $\mathrm{O}$, formulando la pregunta al revés, ¿quién puede interpretar qué no es humano o qué es una violación de un derecho humano? En estos términos aparece la nueva pregunta por el poder en el marco internacional. En un contexto en el que la sustancia común del proyecto político internacional es "ser humano", 2 no cabe duda que quien tenga la facultad de interpretar, de decidir, qué es lo humano y qué no lo es, tiene el poder. ${ }^{3}$

A través de esta cuestión se abre la relación entre los derechos humanos y la política, es decir, la cuestión del poder y del orden. Aquí la trataremos en tres puntos. En primer lugar, se hace necesaria una breve delimitación conceptual de la expresión "derechos humanos"; en segundo lugar, un análisis de qué significa intervención en relación con los derechos humanos, y, en tercer lugar, un análisis del orden político que queda definido desde el momento en que aparece la defensa de los derechos humanos como principio regulador del derecho internacional.

\section{LOS DERECHOS HUMANOS Y SUS AMBIGÜEDADES}

La definición general de la expresión "derechos humanos" es una de las pocas que entrando a formar parte de la lucha política es, sin embargo, unívoca.

Derechos humanos, decía Juan Pablo II en el discurso citado arriba, son aquellos derechos que están arraigados en la naturaleza de la persona, son derechos que reflejan las exigencias objetivas e inviolables de una ley moral universal.

No parecen decir otra cosa los tratadistas de derecho internacional cuando definen los derechos humanos como "derechos fundamentales

2 Schmitt, C., Teoría de la Constitución, p. 167: "La Declaración solemne de Derechos Fundamentales significa el establecimiento de principios sobre los cuales se apoya la unidad política de un pueblo y cuya vigencia se reconoce como el supuesto más importante del surgimiento y formación incesante de esa unidad. El supuesto que da lugar a la integración de la unidad estatal". Los derechos humanos en este sentido son la sustancia misma del nuevo derecho internacional y no sólo un apartado.

3 Recordamos aquí la clásica definición de soberano formulada por C. Schmitt al comienzo de Politische Theologie, p. 11: "Souverän ist, wer über den Ausnahmezustand entscheidet". ("Soberano es quien decide sobre el caso de excepción"). Definición que, como Schmitt mismo reconoció, como estructura formal es perenne y que sólo varía en consonancia con la variación del espacio relevante en el que se pueda producir el conflicto que da lugar a la excepción, en nuestro caso los derechos humanos. 
Este obra forma parte del acervo de la Biblioteca Jurídica Virtual del Instituto de Investigaciones Jurídicas de la UNAM www.juridicas.unam.mx

https://biblio.juridicas.unam.mx/bjv

que el hombre posee por el hecho de ser hombre, por su propia naturaleza y dignidad; derechos que son inherentes y que, lejos de nacer de una concesión de la sociedad política, han de ser por ésta consagrados y garantizados", 4 o como "derechos humanos fundamentales" reconocidos por todo Estado desde siempre,$^{5}$ o, como aparece en la misma declaración, "derechos iguales e inalienables de todos los miembros de la familia humana". 6

Ante una univocidad de expresión, aparece, sin embargo, una ambigüedad de fundamentación que condiciona la interpretación posterior del contenido de los derechos humanos. Los tipos de argumentos se podrían resumir en los siguientes grupos: ${ }^{7}$

- No existe fundamento para los mismos. Hablar de los derechos humanos no puede ser más que una metáfora, aunque útil en la práctica política, porque no se puede hablar de una naturaleza humana en la que esos derechos puedan inherir. Es esta la línea argumentativa de los estructuralistas y posestructuralistas.

- No existe un fundamento absoluto de los derechos humanos en una naturaleza humana, sino que la fundamentación es inmanente a la conciencia del sujeto. Se trata de un fundamento provisional. Los derechos humanos son siempre revisables. En esta línea se argumenta desde el relativismo, el contractualismo, el historicismo $\mathrm{y}$ el funcionalismo.

- Los derechos humanos están fundados en la esencia humana y, por tanto, en la ley natural escrita por Dios en el corazón de los hombres y, en última instancia, en Dios mismo. En este caso, los derechos humanos no se pueden conocer inmediatamente en su totalidad, sino que necesariamente el hombre va descubriéndolos y tomando conciencia de ellos a través de la historia.

Se trata de tres posturas fundamentales ante la realidad en general, o sea, tres concepciones de la realidad de las cuales depende toda la hermeneútica posterior que se haga de la expresión "derechos humanos". Des-

4 Truyol y Serra, Los derechos humanos, p. 11.

5 Verdross, A., p. 541.

6 Es interesante en este punto señalar con Á. d'Ors, La Ley de la ONU versus ley de Dios, p. 595: "Esta ley internacional no invoca para nada la 'naturaleza' del hombre".

7 Seguimos a Possenti, V., pp. 265-266. 
Este obra forma parte del acervo de la Biblioteca Jurídica Virtual del Instituto de Investigaciones Jurídicas de la UNAM www.juridicas.unam.mx

de este punto de vista el concepto se hace tremendamente ambiguo. Y el diálogo acerca de él, peligroso.

Pero vayamos a otro ángulo de análisis del concepto. Tanto en la definición como en los argumentos de fundamentación que hemos esbozado, los derechos humanos pueden parecer como un estadio intermedio entre el derecho natural, el derecho de gentes y el derecho positivo. No son ninguna de las tres cosas y son las tres.

Se podría decir que es derecho natural en el sentido de que materialmente versa sobre un contenido similar. No lo es, sin embargo, porque como bien subraya Á. d'Ors, la ley natural contenida en el derecho natural se presenta sin pretensiones de cumplimiento jurídico, aunque deba tenerlo, y es, por tanto, sólo una ley moral que recuerda los deberes racionales de las personas; sin embargo, la ley de la defensa de los derechos humanos pretende convertirse en positiva (artículos 8 y 12). ${ }^{8}$ Sería entonces una ley positiva cuyo contenido es tan amplio - la moral mismaque nunca puede estar vigente. ¿Quién ejerce los deberes correlativos a esos derechos? La comunidad internacional, que es quien los formula, puesto que pueden no estar recogidos en las Constituciones de cada uno de los Estados. Pero sería utópico pensar que la comunidad internacional cumpla su deber hasta el punto de lograr la vigencia real de todo lo que se recoge en esa declaración. En ese sentido se separarían del derecho de gentes, pues éste es aquel que aunque no esté necesariamente positivizado, siempre esté vigente. Con todo, no se puede decir que no tenga nada que ver con el derecho de gentes primitivo en cuanto que hace referencia no sólo a asuntos públicos en los que intervienen entes públicos, como ocurre en el derecho internacional público, sino que pretende determinar la conducta de los individuos entre sí y de cada Estado con respecto al individuo. Además, la idea de los derechos humanos en relación con el derecho de gentes existe desde antiguo. ${ }^{9}$ Se trata de unos derechos que más que ser de derecho internacional público parecen constituir un derecho de ciudadanía universal.

Cabe, por tanto, una gran ambigüedad a la hora de determinar su estatuto jurídico tal como han venido a ser formulados en la Declaración Universal de los Derechos del Hombre.

Una manera simple de clarificar su estatuto y que nos abre a otra ambigüedad, a saber: el problema de la interpretación arriba mencionado, es

8 D’Ors, Á., La Ley de la ONU versus ley de Dios, p. 597.

9 Verdross, A., pp. 540 y ss. 
Este obra forma parte del acervo de la Biblioteca Jurídica Virtual del Instituto de Investigaciones Jurídicas de la UNAM www.juridicas.unam.mx

https://biblio.juridicas.unam.mx/bjv

concebirlos como una positivización de la esencia de lo humano. Los derechos humanos son derecho positivo porque se ha llegado a un consenso semántico, aunque no material, acerca de qué sea lo humano. ${ }^{10}$ Este problema se pone de manifiesto en cada una de las cumbres que convoca la ONU. Las diferencias ideológicas, religiosas y culturales son máximamente relevantes en la definición de la esencia del ser humano, hasta tal punto que se puede decir que no existe una sola palabra sobre la verdad del hombre sino muchas, aunque cada una de ellas sea universal. A la hora de interpretar lo humano la conciliación entre universal y particular se hace problema. Se podría incluso decir que lo humano mismo, lo que debería ser más común, se hace polémico, objeto de política. Precisamente eso es lo que hace necesaria la declaración universal. Cuando se pone en cuestión lo común hay que definirlo, hacerlo objeto de declaración. Pero eso no cambia la realidad de las cosas. El problema reaparece incluso en el contexto de la Declaración y, en concreto, bajo la forma de los derechos de las naciones.

Ésta fue precisamente la reivindicación de Juan Pablo II ante la Asamblea General de la ONU. Citamos a continuación dos párrafos de su discurso:

Our respect for the culture of others is therefore rooted in our respect for each community's attempt to answer the question of human life. No one is permitted to suppress those rights by using coercitive power to impose an answer to the mistery of man.

Sin duda el responsable de un tal respeto es la ONU, puesto que es ella la que se arroga el derecho de hablar en favor de los derechos del hombre a la hora de intervenir en algún conflicto. Por eso, en el presente estado de las cosas no tiene mucho sentido pensar que cualquier sujeto de derecho internacional intervenga a la ONU alzando la bandera de los derechos humanos y, sin embargo, ¿no es posible también que la ONU pueda conculcar alguna vez esos derechos?

Acabamos de nombrar la palabra clave que nos abre al siguiente tema a tratar: "intervención". Declarar en favor de los derechos humanos no tiene ningún sentido si no se puede actuar para defenderlos. 
Este obra forma parte del acervo de la Biblioteca Jurídica Virtual del Instituto de Investigaciones Jurídicas de la UNAM www.juridicas.unam.mx

\section{LOS DERECHOS HUMANOS COMO TÍTULO DE INTERVENCIÓN}

La primera cuestión aquí es saber qué significa “intervención” o a qué nos estamos refiriendo en este contexto al hablar de intervención.

Hay autores ${ }^{11}$ que defienden una sola posibilidad para la significación de este término, y es la que designa su fórmula técnica. Así, intervención significa una interferencia dictatorial en el sentido de una acción que aumenta su intensidad hasta negar la independencia de un Estado.

El principio de no intervención o, mejor, el respeto a la autonomía política, es un derecho fundamental de los Estados en el derecho internacional público. Es decir, según el derecho internacional común, los Estados tienen el deber recíproco de respetar su independencia política y su ordenación interna. Por independencia política se entiende la facultad que tiene cada Estado para decidir sobre los asuntos internos y externos en el marco del derecho internacional, lo cual significa que cada Estado se mantiene independiente sobre todo con respecto al poder de mando de otro Estado. ${ }^{12}$ Como indica Isensee en el artículo ya citado, prohibición de intervención (Interventionsverbot) significa prohibición del ejercico de un poder (Machtverbot). ${ }^{13}$

La intervención hace referencia siempre al uso de la fuerza, lo cual no remite sólo a la acción militar sino a toda coacción real. Por eso no es fácil delimitar cuándo se da un caso de intervención y cuándo una mera intercesión. En este sentido hoy en día se amplía el límite del concepto, pues para que haya una intervención no es necesaria la compañía de la violencia. Se ha ampliado el espectro de la intervención en la misma medida en que que se ha relativizado la relación poder-territorio. Intervención, sin duda, es también boicot político y económico, presión diplomática, limitaciones de la acción de gobierno, control de prensa, radio y televisión, etcétera. Se amplía el radio de intervención y se amplía también el número de los posibles intervinientes. Propiamente ya no son sólo Estados, sino también organizaciones internacionales, como es el caso de la ONU. En esta ampliación del concepto éste viene a perder todo su sentido, lo cual es un indicio de una crisis en la configuración del orden mundial, como veremos en el tercer punto.

13 Isensee, J., p. 423. 
Este obra forma parte del acervo de la Biblioteca Jurídica Virtual del Instituto de Investigaciones Jurídicas de la UNAM www.juridicas.unam.mx

https://biblio.juridicas.unam.mx/bjv

Aunque a primera vista parezca que existe un sentido unívoco del término se pueden distinguir varios tipos de intervención, ${ }^{14}$ a saber:

a) Intervención unilateral, que es la clásica o la que aquí se ha denominado técnica. Se trata del caso en que un Estado interviene en la política de otro.

b) Contraintervención. Se denomina así a la intervención de un Estado en la política de otro para evitar que un tercero procediera a una intervención similar. Sería una especie de intervención como protección.

c) Intervención colectiva. Es el caso en que un número de Estados se unen para presionar la acción de otro Estado.

d) Intervención regional. Tiene lugar cuando un grupo de Estados formen una entidad jurídica que imponga una voluntad regional, colectiva, a un miembro del grupo que disiente.

e) Intervención universal. Este término se reserva para la intervención realizada por la ONU en consecuencia con la formulación del artículo 1 de la Carta de las Naciones Unidas, fundamentalmente en los parágrafos 1 y 3 , en los que enumera los fines de la constitución de esa organización:

1. To mantain international peace and security, and to that end: to take effective collective measures for the prevention and removal of threats of peace, and for the suppression of acts of aggression or other breaches of the peace, and to bring about by peaceful means, and in conformity with the principles of justice and international law, adjustement or settlement of international disputes or situations which might lead to a breach of the peace; [...].

3. To achieve international cooperation in solving international problems of an economic, social, cultural, or humanitarian character, and in promoting and encouraging respect for human rights and for fundamental freedoms for all without distinction as to race, sex, language, or religion [...].

Y en consecuencia con la restricción impuesta por el artículo 2, parágrafo 7, a saber:

7. Nothing contained in the present Charter shall authorize the United Nations to intervene in matters which are essentially within the domestic ju- 
Este obra forma parte del acervo de la Biblioteca Jurídica Virtual del Instituto de Investigaciones Jurídicas de la UNAM www.juridicas.unam.mx

risdiction of any state or shall require the Members to submit such matters to settlement under the present Charter; but this principle shall not prejudice the aplications of enforcement measures under Chapter VII.

La intervención está prohibida en el derecho internacional salvo en los casos que aparecen implícitos en los parágrafos 1 y 3 del artículo 1 de la Carta. Y en estos, está permitida por la fuerza de la autoridad de los derechos humanos y de la salvaguarda de la paz.

La defensa de los derechos humanos, lo cual es una tarea moral, es la única razón capaz de justificar una intervención. Esa intervención se puede caracterizar de universal en varios sentidos: en primer lugar, se hace por razón de una materia universal, puesto que lo humano es universal; en segundo lugar, se aplica sin discriminación a todo caso en que se considere — estos casos no están tipificados — ${ }^{15}$ que en algún lugar del mundo — abarca toda la humanidad — se está violando algún derecho considerado como derecho humano; en tercer lugar, la sanción es aplicada por una organización que pretende abarcar todas las naciones del mundo y, por tanto, ser universal. Allá donde se pose la vista se encuentra la universalidad.

Ahora bien, ¿hasta qué punto la suma universalidad se corresponde con la suma objetividad y la suma justicia? ¿Hasta qué punto el Consejo de Seguridad de la ONU formado todavía por los cinco grandes está libre de voluntad política y puede prescindir del interés?

De hecho, en los parágrafos citados hay varios motivos de ambigüedad a través de los cuales fácilmente se introduce la voluntad política: " amenazas de la paz", "derechos humanos", "domestic jurisdiction". Lo que signifiquen esas expresiones en concreto queda a la decisión de los órganos de la ONU. Volvemos a la cuestión del principio, ¿quién interpreta?

En cuanto a la cuestión de la paz, se puede decir que el aforismo "entre la guerra y la paz no hay medio" ha quedado sustituido en la política de la ONU por: "entre la guerra y la paz esté la amenaza de la paz". La cuestión decisiva para la intervención en ese punto es la interpretación de qué se considere en concreto una amenaza para la paz, tal como se puede ver en la siguiente declaración de Consejo de Seguridad:

15 Isensee señala en el artículo citado, p. 5, que el tratamiento jurídico de los derechos humanos obligaría a tipificar los casos de intervención porque si no se corre el riesgo de aplicarlos arbitrariamente. Sólo en ese caso es posible aplicar las mismas medidas a Estados que se hallen en la misma situación. 
Este obra forma parte del acervo de la Biblioteca Jurídica Virtual del Instituto de Investigaciones Jurídicas de la UNAM www.juridicas.unam.mx

https://biblio.juridicas.unam.mx/bjv

The absence of war and military conflicts among states does not in itself insure international peace and security. The non-military sources of inestability in the economic, social, humanitarian and ecological fields have become threats to peace and security. The United natins membership as a whole needs to give the highest priority to the solution of these matters. ${ }^{16}$

El problema se plantea en la bibliografía, ${ }^{17}$ sin embargo, sobre todo en torno a la discusión de qué significa la expresión "essentially within the domestic jurisdiction" y más en concreto "domestic jurisdiction" en el más arriba citado artículo 2, parágrafo 7.

En la interpretación de Lauterpacht, ${ }^{18}$ un asunto es doméstico cuando no está regulado por el derecho internacional o no es susceptible de tal regulación. En su opinón, apenas existen esas materias, si es que existe alguna. No es posible, y menos en el contexto mundial de nuestros días, encontrar asuntos que no tengan una repercusión en el ámbito internacional. Mucho menos es un asunto de "domestic jurisdiction" cualquier asunto que pueda llegar a perturbar la paz. Tampoco lo es un asunto sujeto a una obligación internacional. De esto último se deduce que en materia de derechos humanos - y esto es lo que viene a justificar el título de este apartado - no hay ningún asunto de "domestic jurisdiction", si no la Carta entraría en contradicción consigo misma, puesto que no puede prohibir la intervención en aquellos asuntos - económicos, culturales, sociales y humanitarios-que ella ordena promover. ${ }^{19}$

De todas formas, es a los órganos de las Naciones Unidas a quienes compete la decisión sobre el caso de excepción. Así lo expresa Lauterpacht: "[...] it is their duty, with regard to any individual case, to interpret the legal provisions of the Charter in accordance with good faith and not by reference to arbitrary considerations of political interest' ${ }^{20}$

La restricción vendría en la interpretación de Lauterpacht por la supuesta prohibición para la ONU — según el artículo 2, parágrafo 7- de intervenciones que estuvieran asociadas a aplicación de la fuerza. Esta interpretación falla, puesto que el artículo 39 permite medidas coercitivas.

16 "Security Council Summit Declaration: New Risks for Stability and Security", New York Times, 1, Feb. 1992, sec. A, col. 2.

17 Lauterpacht, H., p. 166; Verdross, p. 487; K. K. Pease \& D. Forsythe, p. 292; Rosalyn Higgins, p. 104.

18 Lauterpacht, H., p. 175.

19 Verdross, A., p. 489.

20 Lauterpacht, H., p. 182. 
Este obra forma parte del acervo de la Biblioteca Jurídica Virtual del Instituto de Investigaciones Jurídicas de la UNAM www.juridicas.unam.mx

En resumen, la Carta "no contiene pauta alguna" 21 para dirimir el caso de excepción.

La Carta de la ONU no puede suprimir la existencia de asuntos domésticos, puesto que presupone la existencia de los Estados, sin embargo, deja su espacio indefinido y muy restringido, toda vez que los asuntos de derechos humanos no son de jurisdicción doméstica. Todo espacio doméstico de un Estado queda de este modo siempre a la sombra de la posibilidad de una intervención. ${ }^{22}$

Esto supone de modo indirecto una restricción y relativización de la soberanía estatal en términos políticos. ${ }^{23}$ Pero eso necesariamente empuja a un cambio del orden mundial si no se quiere seguir vivendo en un mundo de paradojas en el ámbito internacional.

\title{
IV. EL CONFLICTO DE DOS ÓRDENES POLÍTICOS: UNIVERSALISMO Y PARTICULARISMO
}

La convivencia de dos tipos de disposiciones: no intervención e intervención en el orden internacional, lleva a pensar que estén funcionando paralelamente dos lógicas diferentes para comprender el orden del mundo. El viraje hacia un derecho internacional universalista no es simplemente una modificación o un progreso en el orden internacional. Con palabras de Álvaro d'Ors:

\begin{abstract}
¿No es la guerra de nuestros días, con su carácter total y mundial, el más claro indicio de que la humanidad postula hoy un sistema jurídico de las mismas dimensiones? Hoy no puede tratarse, pues, de una simple renovación de los principios del derecho internacional, mucho menos de una simple depuración, sino de un planteamiento absolutamente nuevo de las bases político-filosóficas en el que el ordenamiento universal debe fundarse. ${ }^{24}$
\end{abstract}

21 Verdross, A., p. 487: "Sobre la base del Pacto de la S.D.N. (art. 15, apart. 8), la esfera de actuación exclusiva de los Estados había de determinarse a tenor del D. I. mientras que la Carta de la O.N.U. no contiene pauta alguna para enjuiciar la cuestión. De ahí que la interpretación del artículo 2, parágrafo 7 de la Carta dé lugar a dificultades todavía mayores que la interpretación de las respectivas disposiciones del Pacto".

22 Verdross, A., p. 490: "Conviene observar, finalmente, que la Asamblea General siempre ha decidido por sí misma si existe o no la competencia doméstica que alega un Estado, y que nunca se ha reconocido a un Estado la facultad de decidir sobre esta alegación".

23 Isensee, J., p. 421: "La instauración de los derechos humanos convierte la soberanía estatal en permeable y eso, según las reglas de un consistente derecho internacional llevaría consigo una Constitución Universal”.

24 D’Ors, Á., Ordo Orbis, p. 41. 
Este obra forma parte del acervo de la Biblioteca Jurídica Virtual del Instituto de Investigaciones Jurídicas de la UNAM www.juridicas.unam.mx

https://biblio.juridicas.unam.mx/bjv

Ante una variación del derecho, el orden político nunca queda intacto. En el nuevo derecho internacional modificado después de la Segunda Guerra Mundial, funciona por un lado el principio de no intervención al nivel estatal. Ese principio responde a una lógica estatal o particularista, como la hemos denominado aquí. Por otro lado, en un nivel supraestatal se verifica el principio contrario que pertenece a una lógica universalista en virtud de la universalidad de la moral y de la buena voluntad. La dimensión que imponen los derechos humanos al nuevo orden es planetaria, hasta tal punto que, de un modo exagerado, se podría decir que si las cosas siguen por este camino, con el paso del tiempo ya no habrá política exterior sino sólo interior. Pero no se puede olvidar que eso significa una centralización del poder, del cual la policía mundial y el tribunal internacional serían órganos.

Ahora bien, la cuestión está en saber si esos órdenes — particular y universal - se excluyen o no mutuamente. Si pueden o no convivir.

En el discurso de Juan Pablo II ante la Asamblea General de la ONU la reivindicación era precisamente en favor del particularismo conciliador:

And yet precisely against this horizont of universality we see the powerful re-emergences of a certain ethnic and cultural consciousness, as it were an explosive need for identity and survival, a sort of counterweight to the tendency toward uniformity.

Siempre es necesario conciliar las dos tendencias, universalidad y particularidad, puesto que están inscritas ontológicamente en el ser humano. No obstante, el contrapeso es difícil y no parece lograrse en la presente conjunción de órdenes. El futuro parece estar en un orden del mundo sostenido por un solo centro de poder $^{25}$ bajo la égida no de Roma, no del papado, no de Europa, sino de Estados Unidos.

Todo orden presupone una serie de elementos, una distancia respectiva entre ellos por la cual uno no es el otro, y una relación por la cual se pertenecen mutuamente. Es decir, todo orden supone un criterio discriminador de lo que no es el mismo. ${ }^{26}$ Sin criterio discriminador no hay límites, y, por tanto, tampoco un orden. El imperio romano se fundaba en un orden que discriminaba entre ciudadanos romanos y bárbaros; el imperio cristiano, a pesar de haber aportado al mundo el concepto de humanidad,

26 Ver D’Ors, Á., Ordo Orbis. 
Este obra forma parte del acervo de la Biblioteca Jurídica Virtual del Instituto de Investigaciones Jurídicas de la UNAM www.juridicas.unam.mx

es decir, la idea de que todos los hombres somos iguales ante Dios, necesitaba, si quería crear un orden político, discriminar entre pertenecientes y no pertenecientes a la Iglesia. El derecho de gentes europeo que vino a sustituir a la respublica cristiana pretendía justamente deshacer todo tipo de discriminación y postular una comunidad humana universal fundamentada en un derecho natural racionalista; pero el descubrimiento de las nuevas tierras americanas dio lugar a un nuevo concepto discriminador que contribuyó a la transformación del orden del mundo; era la discriminación entre pueblos civilizados y no civilizados que ha permanecido prácticamente hasta el final de la Segunda Guerra Mundial. A partir de este momento se puso el rumbo hacia un orden del mundo universalista que pretende carecer de distinción discriminadora, pero que no sería un orden si no la tuviera.

Podemos aventurar cuál es la distinción relevante del nuevo orden del mundo. Podría ser la distinción humano-inhumano, lo cual llevaría a una horrible criminalización de algunos hombres; o, como apunta Carl Schmitt, en el análisis de este tema, la distinción del hemisferio occidental y el resto del mundo llevada a cabo por el autoaislamiento que se proporciona a sí misma América con la doctrina Monroe; ${ }^{27}$ o bien, como propone Álvaro d'Ors en el artículo citado, la distinción discriminadora es demócrata-antidemócrata.

Pero independientemente de este intento de comprensión del nuevo orden, ¿queda alguna opción a la masificación de un orden universalista centrado en el hemisferio occidental?

Lo diré con palabras de Carl Schmitt:

Frente a la pretensión de control y señorío mundial, universal, de signo planetario, se yergue a la defensiva otro Nomos de la tierra, cuya idea cardinal consiste en distribuir el globo terráqueo en varios espacios grandes, determinados por su sustancia histórica, económica y cultural. ${ }^{28}$

Al menos existen dos nuevos centros de poder posibles que pueden mostrar cómo no hay una sola interpretación de la humanidad y lo humano en el hombre, los cuales configurados de algún modo internacionalmente pueden llegar a formar grandes espacios, a saber: Europa y Asia. 
Este obra forma parte del acervo de la Biblioteca Jurídica Virtual del Instituto de Investigaciones Jurídicas de la UNAM www.juridicas.unam.mx

https://biblio.juridicas.unam.mx/bjv

La realización de esta posibilidad histórica limitaría realmente, y no sólo a través de cláusulas y parágrafos de artículos, el universalismo, y proporcionaría un diálogo real a la hora de tratar los problemas a nivel mundial, puesto que sería un diálogo en el que cada una de las posiciones estaría respaldada por una autoridad y una capacidad de hacerse efectiva.

Desde este ángulo, la conquista de una paz mundial se ve como algo diferente de la consecución de una unidad política mundial. La conquista de la paz mundial ha de fundarse en un orden de paz. Frente a la utopía del universalismo liberal se sitúa una teoría pluralista, para la cual el logro de la paz sólo es posible mediante el desarrollo de una medida para la relación entre diversas unidades políticas, que no hacen más que expresar el pluralismo de la vida del espíritu. Tales relaciones han de quedar recogidas en una ordenación jurídica internacional. Carl Schmitt la venía a describir según el espíritu arriba citado del siguiente modo:

Una ordenación jurídica-internacional no es un tratado ni descansa en un tratado. No es tampoco una alianza ni mucho menos una federación. No tiene constitución en sentido específico, sino que es el reflejo, manifestado en diversas reglas y consideraciones generalmente reconocidas, del pluriverso político; esto es, de la coexistencia de una pluralidad de unidades políticas. $^{29}$

Este pluralismo es la consecuencia necesaria de la libertad humana. El hombre tiene una naturaleza universal, pero existen muchos modos de realizar esa humanidad e incluso de ser un "buen hombre". Justamente esta pluralidad, radical en la ontología misma del ser humano, hace imposible el universo político.

\section{BIBLIOGRAFÍA}

Cambio de estructura en el derecho internacional, manuscrito, RW 265K8/Mt.5.

D’ORs, Á., “Ordo Orbis”, Revista de Estudios Políticos, núm. 35, 1947, pp. 37-62.

FAK, R. A., "The legitimacy of legislative intervention by the United Nations", Essays on Intervention, Ed. by Roland J. Stranger, Ohio University Press, 1964. 
Este obra forma parte del acervo de la Biblioteca Jurídica Virtual del Instituto de Investigaciones Jurídicas de la UNAM

HigGins, R., The development of international law through the political organs of the United Nations, London, New York, Toronto, Oxford University Press, 1963.

ISENSEE, J., "Weltpolizei für Menschenrecht. Zur Wiederkehr der humanitären Intervention", Juristenzeitung 50, Jahrg, 5 Mai, 1995, pp. 421-430.

"La Ley de la ONU versus ley de Dios", Razonalismo. Homenaje a Fernández de la Mora, Madrid, Fundación Balmes, 1995.

LAUTERPACHT, H., International Law and Human Rights, Archon Books, 1968.

NovaK, M. and SchifTER, R., Human Rights and the United Nations, Washington, American, Enterprise Institute for Public Policy Research, 1981.

PEASE, K. K. and FORSYTHE, D. D., "Human Rights, Humanitarian Intervention and World Politics", Human Rights Quarterly, The John Hopkins University Press, vol. 155, Nr. 2, May, 1993, pp. 290-314.

Politische Theologie, Berlin, Duncker \& Humblot, 1979.

Possenti, V., Diritti Umani e natura Umana, Vita Sociale, núm. 262, anno LI, Luglio-Ottobre, 1994, pp. 262-270.

SchmitT, C., Teoría de la Constitución, Madrid, Revista de Derecho Privado, s.f.

The United Nations and Human Rigths, New York, Department of Public Information United Nations, 1995.

TRUyOL Y SERRA, A., Los derechos humanos, Madrid, Tecnos, 1968. 


\title{
LOS DERECHOS HUMANOS EN UNA ÉPOCA DE CRISIS
}

\author{
Ilva Myriam HoYOS CASTAÑEDA
}

SUMARIO: I. Punto de partida. II. El criterio para juzgar la crisis de la sociedad actual. III. La dignidad de la persona y los dederechos humanos. IV. Conclusión.

\section{PUNTO DE PARTIDA}

Sean mis primeras palabras para agradecer muy sinceramente la invitación que me hizo el Instituto de Investigaciones Jurídicas de la Universidad Nacional Autónoma de México (UNAM). La calidad intelectual y moral de sus participantes, la importancia del tema, el esmero con el que el Instituto ha cuidado todos los detalles de tan significativo evento internacional hacen de este Coloquio un lugar propicio para expresar no sólo nuestras dudas e inquietudes sobre la sociedad actual, sino ante todo para reafirmar la esperanza de que el mañana que nos toca forjar será cada vez mejor.

Me propongo insistir en dos cuestiones centrales. La primera, relativa al criterio para enjuiciar la sociedad actual. En la segunda plantearé la tesis central que pretendo defender, en el sentido de que los derechos humanos son una expresión de la recuperación de la dignidad de la persona en una época de crisis.

\section{EL CRITERIO PARA JUZGAR LA CRISIS DE LA SOCIEDAD ACTUAL}

\section{El sentido de los derechos humanos en una sociedad plural}

Una distinción que, a mi juicio, puede plantearse en el estudio de la sociedad actual es, como dice Hervada, la que existe entre la pluralidad y el pluralismo. ${ }^{1}$ La pluralidad es un hecho que se puede dar en diversos

1 Sobre este tema es especialmente significativo el texto de Hervada, Javier, "Pensamientos sobre sociedad plural y dimensión religiosa”, Ius Canonicium, XIX, núm. 38, julio-diciembre, 
Este obra forma parte del acervo de la Biblioteca Jurídica Virtual del Instituto de Investigaciones Jurídicas de la UNAM www.juridicas.unam.mx

https://biblio.juridicas.unam.mx/bjv

órdenes, entre otros en el orden social. La raíz de la pluralidad es la variedad o diversidad de los elementos que forman un todo. La pluralidad social es un hecho, que no es extraño a la vida social porque la sociedad está formada por personas, seres enteramente otros. Una sociedad plural es una sociedad varia, en la que hay seres distintos, diferentes, irreductibles unos a otros. Pero para ser sociedad no basta la pluralidad, se requiere la unidad que los ordena. La pluralidad de individuos unificada por un fin común y por la actividad también común de alcanzarlo es la que conforma la sociedad.

El pluralismo, por el contrario, es una actitud y un principio por el que se estima que la pluralidad debe ser reconocida como estado necesario, normal y perfecto de la sociedad, que exalta la libertad como principio absoluto y fuente de otros principios. El pluralismo denota un juicio de valor en el que se adopta una postura respecto de la organización misma de la sociedad, es principio del orden político que informa toda la actividad social. Sociedad pluralista es aquella que está dominada por una mentalidad pluralista en la que se considera que cualquier idea, convicción o creencia es igualmente deseable en la sociedad, sin importar su contenido ni su referencia a un criterio de verdad. El pluralismo es expresión de un relativismo, es una actitud que reduce la verdad a la opinión, la certeza a un parecer, los bienes a estimaciones subjetivas. No hay de suyo nada bueno ni malo: o todo es aceptable o es la mayoría la que determina qué es aquello que debe realizarse en una situación o época determinada.

La distinción entre la pluralidad en la sociedad y el pluralismo de la sociedad no es una cuestión meramente terminológica. Porque el pluralismo no cabe sino respecto de lo meramente opinable, no es predicable de todos los órdenes de la vida social, porque la sociedad para subsistir requiere de la aceptación de ciertas verdades, sin las cuales no existe como tal ni se puede configurar política y jurídicamente como sociedad justa. ${ }^{2}$

1979, pp. 63 y ss. Publicado en la obra del mismo autor: Cuestiones de derecho canónico y afines (1958-1991), Madrid, Eunsa, 1991, vol. I, pp. 777 y ss.

2 Así, por ejemplo, cabe un pluralismo de carácter político, como el que se reconoce, entre otras, en la Constitución española de 1978 y en la Constitución Política de Colombia de 1991. Pero es inconcebible un pluralismo religioso en el que se adopte como principio el de la relatividad de la verdad religiosa, principio con el que se fomenta por parte del Estado o de la sociedad la multiplicidad de opciones y creencias religiosas, sin importar que sean contradictorias o contrarias, en tanto el factor religioso se asume como elemento de la organización política y jurídica de una sociedad. Se trata de un Estado cuya confesionalidad es el pluralismo religioso. Distinta es la pluralidad religiosa, en la que el Estado no asume lo religioso como parte de la estructura social y en la que acepta, por el 
Este obra forma parte del acervo de la Biblioteca Jurídica Virtual del Instituto de Investigaciones Jurídicas de la UNAM www.juridicas.unam.mx

https://biblio.juridicas.unam.mx/bjv

La pluralidad, por el contrario, no niega que en la sociedad puedan darse variedad de opiniones y de opciones en distintas materias, pero parte de que en ella hay cierta unidad. Unidad que hoy en día se expresa mediante el reconocimiento y garantía de los derechos humanos.

En el pluralismo, la legalidad y la moralidad se relativizan. La ley, expresión del pluralismo, es la ley pactada, consensuada no sólo en el momento de su emanación, sino en el de su interpretación y aplicación. El contenido no se determina con base en algo objetivo, sino en un parecer, en una opción, en una opinión. En materia jurídica, este relativismo significa que todas las proposiciones normativas son relativas, esto es, que los contenidos del ordenamiento jurídico son radical y exclusivamente históricos, que no tienen soporte natural alguno.

La sociedad pluralista termina siendo una sociedad permisiva, en la que la moral o la ética, entendida como las normas que representan un deber ser, no son sino represiones, tabúes, imposiciones sociales de las que el hombre para ser realmente auténtico debe liberarse. La moral se concibe como una actitud individual, un problema de conciencia, la que se cualifica como autónoma, porque es la conciencia del individuo la que determina el obrar del hombre, la que fija su criterio de verdad y de maldad. En el trasfondo de la sociedad pluralista todo queda reducido a las fuerzas sociales o a la conciencia de los individuos.

No deja, sin embargo, de ser paradójico que en esa misma sociedad pluralista se hable insistentemente de justicia, de estructuras injustas, de protección de los derechos humanos, de la dignidad de la persona. En el contexto ideológico del pluralismo, del relativismo y del permisivismo esto es una clara contradicción. Porque si los comportamientos sociales vienen determinados por los hechos, si las leyes son el resultado de una mentalidad dominante que se expresa en el consenso, mediante el acuerdo de diversas posturas, si toda conciencia del deber ser es una represión; los derechos humanos lo que representan no es otra cosa que una opción meramente humana, que sería tan legítima y tan válida legal y moralmente como su contraria. De ahí que para algunos los derechos humanos, desde esta consideración, no sean sino edictos revocables. Sin embargo, en esa misma sociedad pluralista difícilmente se podría aceptar socialmente como válido algo que vaya en contra de los derechos humanos. El relati- 
Este obra forma parte del acervo de la Biblioteca Jurídica Virtual del Instituto de Investigaciones Jurídicas de la UNAM www.juridicas.unam.mx

https://biblio.juridicas.unam.mx/bjv

vismo se funda en un absoluto, con el que se explica la igualdad de todas las posturas y de todas las concepciones en torno a la interpretación del hombre y de la sociedad. Los mismos que niegan la existencia de un deber ser califican de injusta la sociedad que no protege sus derechos. Los mismos que desconocen la existencia de una normatividad por encima del Estado aceptan la existencia de algunos derechos que no pueden explicarse, fundamentarse ni protegerse en el exclusivo ámbito de lo estatal. Esta es la más íntima contradicción de toda forma de relativismo. Porque si no existe un orden de justicia, un derecho diferente al pactado socialmente, si no hay un deber ser objetivo, no puede condenarse en defensa de los derechos humanos ninguna conducta humana, ninguna ley, ninguna sociedad, ninguna estructura social, ningún régimen político, ningún gobierno.

\section{La libertad: supuesto de la democracia y de los derechos humanos}

La democracia no ha dejado de ser una forma de régimen político o, para decirlo de manera clásica, una forma de gobierno, no la única ni la necesaria, pero sí, la más admisible y la que ha funcionado mejor, hasta cierto punto, que cualquier otro sistema político conocido. ${ }^{3}$ La democracia se refiere a la manera de acceder los ciudadanos al poder. Como régimen político, la democracia abarca tres aspectos principales: poder participar en la formación de la voluntad política; poder gobernar o acceder libremente a las diversos órganos de poder; poder controlar al gobierno de manera que los ciudadanos garanticen entre sí la efectiva protección de las libertades públicas.

El poder participar, gobernar y controlar presupone la existencia de la libertad y de la igualdad, es decir, que la democracia tiene un fundamento real y objetivo, que no puede desconocer porque de hacerlo ella misma se destruiría. ${ }^{4}$ Por ello, la democracia es también concebida como un régimen de libertad. No resulta extraño que un sector de la doctrina considere algunos derechos humanos, especialmente los llamados de la primera generación, como libertades públicas, para querer significar que la organización política no puede desconocer ese ámbito propio de la libertad esen-

3 "My principal argument shall be that pluralist democracy as a politicial system based upon the rule of law and anchored in a written constitution is the most realistic answer to man's political frailty (i. e. to abuse power). A Constitution cannot and should not define the 'Wertgrundlage' of the democratic order. No political order has as yet been deviced by wich man's civic frailty (his moral behavior) can be coped with adequately". Von Geisai, Alting, Between pluralism..., cit., abstract.

4 Centesimus Annus, 46; Veritatis Splendor, 101. 
Este obra forma parte del acervo de la Biblioteca Jurídica Virtual del Instituto de Investigaciones Jurídicas de la UNAM www.juridicas.unam.mx

https://biblio.juridicas.unam.mx/bjv

cial de toda persona, que jurídicamente se traduce en la protección de las libertades esenciales en todo sistema democrático: la libertad de conciencia, la libertad religiosa, la libertad de pensamiento, la libertad de cátedra y la libertad de prensa.

Con el reconocimiento a nivel constitucional e internacional de estas libertades se admite una gran verdad. No es el Estado ni la sociedad el sujeto del pensamiento, de la conciencia moral, del acto radical de adhesión del hombre a Dios. La sociedad democrática, por más democrática que sea, no es el agente de la cultura, de la religión, del pensamiento. Es la persona la que piensa, la que actúa conforme a su conciencia, la que se relaciona radicalmente con Dios, el que el Estado o la sociedad protejan esos actos de la persona no afecta para nada el carácter personal de la libertad de pensamiento, de la libertad de conciencia o de la libertad religiosa, para citar sólo tres libertades que se suelen confundir, pero que tienen objeto distinto. Libertades que — claro está—, por ser de la persona tienen necesariamente una incidencia en la vida social. Esas libertades no deben ser defendidas en razón de un libre pensamiento; tampoco son la base de una actitud tolerante por la que se debe soportar o permitir algo que no se tiene por bueno o por lícito. Es por ello que las libertades de pensamiento, de conciencia y de religión no tienen un carácter residual, no son mera ausencia de coacción, en cuya virtud la organización política no coaccionaría a quienes no adopten las ideas, convicciones o creencias formuladas desde las mismas estructuras de poder, y en el caso de no ser éstas aceptadas sólo por razones de tolerancia serían admitidas. Esas libertades son manifestación de la autonomía de la persona, autonomía no absoluta sino referida a la estructura ontológica del ser personal.

Si la libertad depende fundamentalmente de la verdad, ${ }^{5}$ sólo podrá enjuiciarse en debida forma la sociedad y la democracia actual si se adopta como punto de partida la verdad acerca de la persona humana y de la sociedad. Esto significa que la democracia también necesita estar justificada por una racionalidad objetiva, realidad dada al hombre, que le señale su legitimidad y determine el contenido de aquello que tiene un carácter justo. Esa verdad sobre la persona humana también incluye la verdad sobre la libertad. No es la libertad un absoluto, que encuentre en sí misma su sentido y su plenitud; ella está fundada o radicada en la persona, y en- 
Este obra forma parte del acervo de la Biblioteca Jurídica Virtual del Instituto de Investigaciones Jurídicas de la UNAM www.juridicas.unam.mx

cuentra su sentido en la ordenación al bien, a los fines a los cuales está orientada la persona.

Considero conveniente reiterarlo. No es el consenso democrático el que configura la libertad ni los demás derechos humanos. Por el contrario, el consenso sólo es posible respecto de algo sustancial, que no esté bajo la condición de ningún pacto. En este sentido, los derechos humanos, auténticos derechos naturales, son el fundamento mismo para que exista el consenso democrático.

\section{La Constitución y la determinación de los valores fundamentales del orden democrático}

La dignidad de la persona y su expresión jurídica, es decir, los derechos que se derivan de ella, son algunos de esos principios que se constituyen en el supuesto de toda Constitución y de toda regulación sobre los derechos humanos. Cuestiones éstas que no deben considerarse como la simple expresión de un pluralismo, porque no es el pretendido pluralismo de la sociedad el que funda la dignidad de la persona, sino — como lo hemos expresado- , la dignidad de la persona la que justifica la pluralidad en la sociedad. Admitir este principio supone aceptar previamente la existencia de una juridicidad y de una normatividad anterior a la misma Constitución. Una juridicidad y normatividad preestatal, base a su vez de cualquier derecho o ley positiva. Esto se advierte en las modernas Constituciones, en las que el Estado acepta la existencia de derechos que bien podrían ser considerados formalmente como preconstitucionales, preexistentes a la ley positiva. En el acto constituyente no se crean, se reconocen, se acepta su existencia jurídica antes de que la Constitución como tal exista.

El problema se plantea no en relación con aquellas Constituciones que reconocen en debida forma la existencia de esos derechos humanos y que estructuran la sociedad con base en el respeto de la dignidad de la persona, sino que surge respecto de aquellos ordenamientos jurídicos que establecen un modelo de sociedad en el que abiertamente se lesiona ese orden natural preexistente, como puede ser el desconocimiento del derecho de libertad religiosa. Tendría que decirse, con el pensamiento clásico, que se está en presencia de una ley injusta, que en estricto sentido no es ley ni obliga. Si es el sistema democrático el que establece una ley injusta, no se trata propiamente de una democracia, sino de una demagogia o 
Este obra forma parte del acervo de la Biblioteca Jurídica Virtual del Instituto de Investigaciones Jurídicas de la UNAM www.juridicas.unam.mx

https://biblio.juridicas.unam.mx/bjv

de una tiranía. En otras palabras, el orden democrático para ser orden debe respetar el derecho y la justicia. Negar esto es trastocar los términos del problema, es enmascararlo en referencia a una —como también dice Von Geusau - alegada crisis de las democracias ${ }^{6}$ y darle un sentido a la democracia que no le es propio.

El contenido de la ley en los sistemas democráticos no se puede ni se debe determinar por la mayoría. Éste es el sinsentido de someter a votación normas o principios del orden natural, como, por ejemplo, el aborto, la eutanasia, el divorcio, el mal llamado matrimonio entre homosexuales, la despenalización del consumo de droga. Es cierto que son democráticos, pero aún así el aborto democrático, la eutanasia democrática, el divorcio democrático, el matrimonio democrático entre homosexuales, la despenalización democrática del consumo de droga, no dejan de lesionar el orden natural, la dignidad de la persona y los derechos que le son propios. Y en cuanto tales no por ser democráticos dejan de ser lesión al derecho, esto es, injusticia. No se trata de un simple problema de conciencia ni de una postura filosófica que se asimile a otras en razón del pluralismo. Si se admite la existencia de un orden natural, la transgresión de ese orden es real y afecta no primariamente a unas ideas o creencias sino, lo que es más importante, a la persona y a la sociedad.

Pero podría decirse que tanto el aborto, la eutanasia, el divorcio, el matrimonio entre homosexuales, la despenalización del consumo de droga, se defienden, precisamente, por ser considerados como mecanismos para proteger derechos humanos. Los mal llamados derechos a atentar o lesionar contra la dignidad de la persona. Ésta es otra paradoja de la sociedad actual, en la que se admite por defensa al derecho e incluso a la dignidad de la persona, concebida como autonomía absoluta, que existan derechos humanos que atenten contra el hombre mismo. De manera objetiva se pretende legitimar el inexistente derecho al mal. Allí no hay derecho, ni lo que clásica ni lo que convencionalmente se llama derecho, porque no puede ser jurídico aquello que va contra el hombre, y en cuanto tal no puede ser humano. Es el antiderecho, la negación del mismo por ser inhumano.

Tampoco puede sostenerse que las normas democráticas que establecen esos mal llamados derechos deben ser aceptadas por razón del princi-

6 "Although the question has been hotly debated ever since Plato, I shall stay within the Conference theme: the alleged moral crisis of (modern, pluralist), democracy". Von Geusau, Alting, Between pluralism..., cit., abstract. 
Este obra forma parte del acervo de la Biblioteca Jurídica Virtual del Instituto de Investigaciones Jurídicas de la UNAM www.juridicas.unam.mx

https://biblio.juridicas.unam.mx/bjv

pio de la tolerancia o del principio del pluralismo político, porque la verdad acerca de la persona y de las exigencias morales y jurídicas que de ella emanan no pueden ser objeto de votación alguna. Lo que sí resulta comprensible es que la concepción positivista, en cualesquiera de sus diversas modalidades, no acepte que los derechos humanos se deriven de la dignidad de la persona humana, porque ningún consenso ni pacto ni votación puede hacer que la persona en razón de su dignidad tenga derechos que le sean inherentes.

\section{La crisis y su referencia a la persona}

Sostienen algunos autores al hablar de la crisis, que ésta está en cada uno de nosotros, no en la democracia ni en el orden político. Su afirmación podría querer significar que la crisis es un problema meramente subjetivo, que el enjuiciamiento que se hace de la sociedad actual no parte de la realidad. Sin embargo, la afirmación —a mi juicio — debe entenderse en su sentido estricto recuperando la noción original de la crisis, del verbo griego krinein, es decir, la acción de distinción o de discernimiento, el juicio en el que se juzga anteriores opiniones, ideas o sistemas filosóficos establecidos. Este modo de discernimiento se justifica porque existe un desajuste, un desequilibrio, una mutación, una ruptura del orden en el que ciertos postulados se han agotado, y ciertos modos de afrontar la vida ya no responden a las nuevas cuestiones que al hombre le plantea el mundo en el que vive. ${ }^{7}$

Pero no sólo se trata de una crisis de ideas, de convicciones o de creencias, sino también de acciones que resultan no ajustadas a las exigencias del ser personal. Se trata de acciones injustas que lesionan el orden natural. En este sentido, el criterio para enjuiciar la sociedad actual y la democracia, o cualquier otra forma de gobierno, es de carácter objetivo, es la persona misma. La causa de la crisis actual es la pérdida teórica y práctica del respeto por la dignidad de la persona humana.

Desde esta consideración, no sólo la persona es el ser que vive la crisis, sino el que la supera. Pero también, y esto es especialmente significativo, es el criterio para enjuiciar y superar esa desorientación que le produce al hombre tantos modelos invocados por las ideologías que oscurecen las exigencias dimanantes de la misma estructura ontológica de la persona hu-

7 Polo, Leonardo, "Conciencia de crisis en la sociedad contemporánea", Presente y futuro del hombre, Madrid, Rialp, 1993, pp. 128 y ss. 
Este obra forma parte del acervo de la Biblioteca Jurídica Virtual del Instituto de Investigaciones Jurídicas de la UNAM www.juridicas.unam.mx

https://biblio.juridicas.unam.mx/bjv

mana. La doble dimensión de la crisis remite necesariamente a la persona. En efecto, la dimensión negativa denota la inseguridad, la inestabilidad, la desorientación y la desconfianza que le produce a la persona misma la ruptura, la mutación, el cambio de ideas y de creencias; y la positiva, se expresa en el hecho de abrirle a la persona nuevos horizontes vitales, que le implican a ella misma replantearse conceptos básicos que le permitan renovar las convicciones que han perdido su fuerza, y así resolver la situación problemática en la que el ser humano vive. Para decirlo con otras palabras, la crisis de la época actual radica en la desorientación sobre el ser personal, pero como la persona vive en sociedad, esa desorientación también abarca al ser mismo de la sociedad.

\section{La crisis de la democracia y los derechos humanos}

La época actual, además de ser caracterizada como época de crisis, es también la época de los derechos. O, para decirlo con el sugerente título de la traducción castellana del libro de Norberto Bobbio: L'età dei diritti, El tiempo de los derechos. ${ }^{8} \mathrm{Si}$ se acepta la afirmación del jurista italiano, en el sentido de que el problema de la conceptuación y de la vigencia de los derechos humanos está estrechamente conectado con la democracia y la paz, porque sin derechos humanos no hay democracia y sin democracia no hay paz; ${ }^{9}$ debe, en igual forma, aceptarse que la crisis de las democracias occidentales es también la crisis de los derechos humanos. Así, si la época actual es época de crisis, de esta crisis no se excluye nada; por ende, en ella también deben incluirse los derechos humanos. La crisis de la verdad que caracteriza la sociedad contemporánea es, en igual forma, la crisis de la verdad sobre los derechos humanos.

Expresión de esta crisis es vivir en el tiempo de los derechos sin derechos. Ésta es otra paradoja de la época actual, de la que tanto han hablado juristas, filosófos, políticos, sociólogos y hombres de Estado: a pesar de que el hombre hoy en día es más consciente de sus derechos y de su dignidad, cada día vive sin menos justicia y sin paz. Esta relación in-

8 Bobbio, Norberto, El tiempo de los derechos, Madrid, Ed. Sistema, 1991.

9 "Derechos humanos, democracia y paz son tres elementos necesarios del mismo movimiento histórico: sin derechos humanos reconocidos y protegidos no hay democracia; sin democracia no existen las condiciones mínimas para la solución pacífica de los conflictos. Con otras palabras, la democracia es la sociedad de los ciudadanos, y los súbditos se convierten en ciudadanos cuando se les reconoce algunos derechos fundamentales; habrá una paz estable, una paz que no tenga la guerra alternativa, sólo cuando seamos ciudadanos no ya solamente de este o aquel Estado, sino del mundo", El tiempo..., cit., p. 14. 
Este obra forma parte del acervo de la Biblioteca Jurídica Virtual del Instituto de Investigaciones Jurídicas de la UNAM www.juridicas.unam.mx

https://biblio.juridicas.unam.mx/bjv

versamente proporcional entre el conocimiento de los derechos y su desconocimiento, es más preocupante porque no sólo se da el abismo entre la teoría y la praxis de los derechos humanos, ${ }^{10}$ sino que incluso se hace aún más difícil saber cuáles y cuántos son esos derechos. Los derechos humanos parecen ir perdiendo su nota de inmutabilidad, y lo que es más preocupante, la referencia exclusiva al hombre. Hoy es corriente defender, sobre todo entre los ecologistas, los derechos de los animales y los derechos de la naturaleza. Vistas así las cosas, la crisis de los derechos humanos, expresión de la crisis de las democracias occidentales, es también la crisis del derecho.

Se debe, sin embargo, al hablar de los derechos humanos, evitar caer en el peligro de llegar a afirmar que si las democracias occidentales han fracasado en el intento de establecer en el ámbito de las relaciones sociales la justicia y la paz, la mejor forma de lograr la anhelada justicia y la buscada paz es establecer un nuevo sistema de gobierno o suprimir el discurso y la retórica de los derechos humanos por otro tipo de discurso en el que no se haga tan ostensible el abismo entre su comprensión teórica y su realización práctica. Al valorarse o al enjuiciarse la crisis, como lo decía Giusseppe Capograssi en el curso organizado por la Universidad de Padua en 1951 sobre la crisis del derecho, ${ }^{11}$ hay que andar con cautela, ${ }^{12}$ porque se corre el riesgo de darle a la crisis un contenido más emocional que racional. Estamos, sin duda alguna, ante una nueva complejidad, cuyos problemas de compatibilidad y coordinación son tan agudos que dificultan no sólo el análisis sino la superación misma de la crisis.

La crisis del derecho y la crisis de los derechos humanos no puede llevarnos a negar la existencia del derecho ni de los derechos humanos, ni tampoco a dejar de resaltar la importancia que a nivel jurídico, político, económico, social tiene el problema del reconocimiento, protección, pro-

10 Sigue siendo hoy en día válida la preocupación expresada por Bobbio en la ponencia presentada en el Convegno Nazionale sui Diritti dell'Uomo, celebrado en Turín del 1 al 3 de diciembre de 1967. En esta oportunidad el jurista italiano expresó: "No se trata tanto de saber cuáles y cuántos son esos derechos, cuál es su naturaleza y su fundamento, si son derechos naturales o históricos, absolutos o relativos, sino cuál es el modo más seguro para garantizarlos, para impedir que, a pesar de las declaraciones solemnes, sean continuamente violados", "Presente y porvenir de los derechos humanos”, Anuario de Derechos Humanos, Madrid, 1981, I, p. 9. Tesis que reitera en el trabajo presentado al Congreso Internacional sobre Sociología del Derecho, realizado en mayo de 1988, titulado "Derechos del hombre y sociedad", El tiempo..., cit., pp. 113 y ss.

11 La crisi del diritto, Padova, Cedam, 1953, Casa Editrice Dott. Antonio Milani. Hay traducción castellana: AA. VV., La crisis del derecho, Buenos Aires, Ediciones Jurídicas Europa-América, 1961, por la que se citará.

12 Capograssi, Giuseppe, "La ambigüedad del derecho contemporáneo", La crisis..., cit., p. 35. 
Este obra forma parte del acervo de la Biblioteca Jurídica Virtual del Instituto de Investigaciones Jurídicas de la UNAM www.juridicas.unam.mx

https://biblio.juridicas.unam.mx/bjv

moción y garantía de los derechos humanos tanto a nivel nacional como internacional. Es difícil no intentar hoy en día la defensa de los derechos humanos, pero esos derechos por sabidos, proclamados y tutelados no deben dejar de defenderse, máxime cuando más se desconocen. No puede concebirse una sociedad futura, en la que exista o no exista crisis, sin referencia al derecho y a los derechos humanos. Ya que no es concebible una sociedad sin personas y personas sin derechos. La íntima relación entre la persona, el derecho y la sociedad debe tenerse muy en cuenta en el momento de enjuiciar la época actual y de renovar esas convicciones que han perdido su fuerza y han desgarrado profundamente al hombre. Se trata, en definitiva, de una crisis de los fundamentos, que afecta radicalmente al saber científico y ante todo al saber filosófico.

Esta crisis de los fundamentos también hace referencia a la crisis de los fundamentos de los derechos humanos. Así, desde 1964 lo reconoció Bobbio, ${ }^{13}$ aunque en su planteamiento la superación de la crisis no puede hacerse de manera absoluta, porque, a su juicio, toda búsqueda del fundamento absoluto está infundada, ya que no puede darse un fundamento absoluto a derechos históricamente relativos. Ésta es otra contradicción de la época actual: proclamar la existencia de derechos universales, pero negarles, por una parte, su carácter de derechos y, por otra, su carácter universal. Si se les niega su existencia como derechos o su nota de universalidad y se les deja al arbitrio del consenso y del pacto, lo que se estaría negando sería la objetividad de derechos y reglas derivados de la dignidad de la persona humana. Lo que radicalmente implicaría vaciar al hombre de su dignidad, sustituyéndola por la voluntad política.

13 "Que exista una crisis de los fundamentos es innegable. Es necesario ser consciente de ella, pero no intentar superarla buscando otro fundamento absoluto para sustituir el perdido. Nuestra tarea, hoy, es mucho más modesta, pero también más difícil. No se trata de encontrar el fundamento absoluto - empresa sublime, pero desesperada-, sino, cada vez, los varios fundamentos posibles. Sin embargo, también esta investigación de los fundamentos posibles —empresa legítima y no destinada como la otra al fracaso - no tendrá ninguna importancia histórica si no es acompañada del estudio de las condiciones, de los medios y de las situaciones en las que este o aquel derecho puede ser realizado. Tal estudio es la tarea de las ciencias históricas y sociales. El problema filosófico de los derechos humanos no puede ser disociado del estudio de los problemas históricos, sociales, económicos, psicológicos, inherentes a su propia realización: el problema de los fines del de los medios. Esto no significa que el filósofo no está solo. El filósofo que se obstina en permanecer solo termina por condenar la filosofía a la esterilidad. Esta crisis de los fundamentos es también un aspecto de la crisis de la filosofía", Bobbio, Norberto, "L'illusion du fondement absolu", en AA. VV., Les fondements des droits de l'homme, Actes des entrentiens de L'Aquila (14-19 septembre 1964), Firenze, Institut International de Philosophie. La Nuova Italia, 1966, pp. 5 y ss. Hay varias traducciones castellanas, se cita por la publicada en El tiempo..., cit., pp. 61 y 62. 
Este obra forma parte del acervo de la Biblioteca Jurídica Virtual del Instituto de Investigaciones Jurídicas de la UNAM www.juridicas.unam.mx

La superación de la crisis de la fundamentación de los derechos humanos es, en igual forma, la superación de la crisis sobre la conceptuación del derecho, porque dependiendo de la fundamentación se conceptuará el derecho de una forma u otra. Pretender superar la crisis de la comprensión de los derechos humanos, no es nada distinto que intentar superar la crisis de los fundamentos, esto es, volver al fundamento mismo, a la razón para que los derechos humanos existan.

\section{La crisis moral es también crisis de la justicia}

La crisis de las democracias, en tanto crisis moral, no deja de ser también una crisis de la justicia, que no es nada distinto que la generación día a día de más y más injusticias. La crisis, hemos dicho, no es un problema de meras creencias, de opciones políticas o de concepciones filosóficas. Es también un problema real que se traduce en acciones concretas que generan un desorden en la sociedad, en tanto en cuanto esas acciones lesionan auténticos derechos.

Desde la concepción jurídica, el problema de la crisis es el de la ruptura de un orden, el de la lesión no primariamente de normas, valores o estimaciones, sino la lesión de los bienes debidos a la persona y, por ende, el desconocimiento de la misma dignidad de la persona. Hay que insistir en esta idea. La sociedad no está en crisis, por lo menos desde la formalidad jurídica, porque se lesione un valor o estimación subjetiva acerca de lo que se estime es justo. Tampoco por contradecir la idea del derecho aceptada comúnmente, sino por lesionar el derecho, esto es, por afectar a la persona en los bienes que le son debidos. Sin acciones lesivas del derecho, sin actos libres y conscientes no hay injusticia y, por ende, no hay crisis. Puede decirse con Von Geusau que la crisis en cierto sentido está en la persona, lo está en tanto que en ella se lesiona voluntariamente el derecho del otro. Pero al lesionarse ese derecho se agravia también a la sociedad y se lesiona la justicia legal, generando el desorden social y afectando la búsqueda del orden social justo.

\section{LA DIGNIDAD DE LA PERSONA Y LOS DERECHOS HUMANOS}

\section{La recuperación de la noción de persona}

¿Cómo hacer compatible la crisis del derecho, la crisis de los derechos humanos, la crisis del fundamento de los derechos humanos, la crisis de la justicia, con la tesis que pretendemos defender en este coloquio, en 
Este obra forma parte del acervo de la Biblioteca Jurídica Virtual del Instituto de Investigaciones Jurídicas de la UNAM www.juridicas.unam.mx

https://biblio.juridicas.unam.mx/bjv

el sentido de que los derechos humanos son la expresión de la recuperación de la dignidad de la persona en una época de crisis? ¿Acaso los derechos humanos no son más bien la expresión de esa crisis? Vayamos por partes para intentar dar respuesta a estos interrogantes.

Para tal efecto, es conveniente precisar cuáles son las notas que caracterizan o tipifican los derechos humanos. No es ésta, sin lugar a dudas, tarea fácil. No sólo en razón de la abundante bibliografía sobre este tema, sino por la diversidad de las posturas filosóficas y jurídicas que han conceptuado o justificado esos específicos derechos. ${ }^{14}$ En el intento de describir las notas de los derechos humanos una vía válida, aunque obviamente no la única, es la de adoptar como punto de partida las declaraciones de derechos del siglo XVIII o del siglo XX, documentos que, como lo dice Charles Taylor, forman parte de la cultura legal de Occidente. ${ }^{15}$ Pues bien, para estos documentos jurídicos los derechos humanos son esenciales, fundamentales, iguales, inalienables e inherentes a la dignidad de la persona. ${ }^{16}$ Con cada una de estas denominaciones lo que se pretende resaltar es que los derechos humanos no se confunden con la ley y que son preexistentes a la ley positiva. Pero no sólo ello, sino que esos derechos son base de la sociedad política y pilar fundamental de un régimen de derecho. Entre las notas características de los derechos humanos podrían mencionarse las siguientes: a) son auténticos derechos, es decir, no son meros ideales a alcanzar, apreciaciones subjetivas, valoraciones, principios morales, postulados políticos o requerimientos sociales; b) son inherentes a la naturaleza humana o a la dignidad de la persona; c) son preexistentes a la ley positiva, y d) son constitutivos de la sociedad. La nota esencial que subsume a las demás es la de ser inherentes a la naturaleza humana o a la dignidad de la persona; por esta razón, los derechos humanos son anteriores a la ley positiva y base constitutiva de la sociedad.

$\mathrm{El}$ que los derechos humanos sean inherentes ${ }^{17}$ a la naturaleza humana o a la dignidad de la persona significa que esos derechos no pueden separarse

14 Sobre este tema se pueda consultar Serna Bermúdez, Pedro, Positivismo conceptual y fundamentación de los derechos humanos, Pamplona, Eunsa, 1990.

15 Taylor, Charles, O., "Los fundamentos filosóficos de los derechos humanos. Complemento a la relación del profesor Mathieu", Los fundamentos de los derechos humanos, Barcelona, Serbal/Unesco, 1985, p. 52.

$16 C f r$. Hervada, Javier y Zumaquero, José M., Textos internacionales de derechos humanos, 2a. ed., I, 1776-1976, Pamplona, Eunsa, 1992.

17 Real Academia de la Lengua, Diccionario de la Lengua Española, Madrid, Espasa-Calpe, 1992, 21a. ed. El mismo significado tiene el inglés inherent, que es sinónimo de intrinsic, essential, se usa para significar un "essential element of something", para significar "belonging to the intrinsic 
Este obra forma parte del acervo de la Biblioteca Jurídica Virtual del Instituto de Investigaciones Jurídicas de la UNAM www.juridicas.unam.mx

https://biblio.juridicas.unam.mx/bjv

de la persona, porque están unidos a ella de tal forma que la persona y los derechos humanos son inseparables: el derecho supone la persona, la persona es el hypokeímenon, el subjectum o el supuesto del derecho. Filosóficamente diríamos que los derechos humanos son propiedades que requieren la existencia de una sustancia, son lo propio. Se trata de bienes que se inhieren a una realidad sustancial, por no tener la capacidad de ser en sí sino de ser en otro. Los derechos humanos no se dan sino en referencia a la realidad sustancial a la que se inhieren, no tienen existencia independiente del alguien que los sustenta y en el cual existen.

Los derechos humanos recuperan la noción de la persona como sujeto de derechos. ${ }^{18}$ La persona, de ser una simple categoría abstracta, formal, sin ningún correlato real o ausente de cualquier contenido, vuelve a ser el supuesto, el ser subsistente en el que se inhieren unos derechos. Ser corpóreo-espiritual, que no es meramente corporeidad, sino corporeidad animada. La persona es el ser humano concreto; en sentido jurídico no designa el papel, la función que el hombre cumple en sociedad; no se trata del actor sino del autor $^{19}$ de la vida jurídica, que tiene una dignidad propia que el derecho debe reconocer y respetar. Se trata de un titular diferente y único, irreductible a cualquier otro. Si la realidad jurídica es un entramado de relaciones jurídicas, la persona es el sujeto de la relación jurídica como titular de derechos y deberes. Esa relación no es meramente lógica; es una ordenación real que vincula jurídicamente personas y bienes concretos. La persona, en tanto que sujeto de derechos, también es irreductible,$^{20}$ en razón de la inalienabilidad e indivisibilidad de su ser personal. El titular de los derechos humanos es cada persona, el alguien subsistente,

nature of that wich is spoken of", en The Oxford English Dictionary, Oxford, 1978. Igual cosa se puede decir en relación con el francés inhérent, que quiere decir "qui par sa nature est joint inséparablement à un sujet", Dictionnaire de l'Academie Française, Genève, 1978. Sobre este tema consultar Hervada, Javier, "Los derechos inherentes a la dignidad de la persona humana", Humana Iura, I, 1991, pp. 345 y ss.

18 Amato, Salvatore, Il soggetto e il soggetto di diritto, Torino, G., Giappichelli Editore, 1990.

19 Trigeaud, Jear-Marc, "La personne", Persona ou la justice au double visage, Genova, Biblioteca di Filosofia Oggi, 1990, pp. 49 y ss. Sobre el mismo tema y del mismo autor: "La personne humaine, sujet de droit", Métaphysique et éthique au fondement du droit, Bordeaux, Bière, 1995, pp. 341 y ss.

20 Trigeaud, Jear-Marc, "Le cercle sans origine ou l'éternel anti-humanisme du 'droit abstrait'”, Persona ou..., cit., p. 70. Cfr., sobre el mismo autor y en la obra mencionada el artículo Qui t'a fait juste? Des filiations personnelles, pp. 333 y 334. Del mismo autor, "L'ordination du bien commun au respect de la personne dans la philosophie politique thomiste", Élements d'une philosophie politique, Bordeaux, Bière, 1993, p. 134. 
Este obra forma parte del acervo de la Biblioteca Jurídica Virtual del Instituto de Investigaciones Jurídicas de la UNAM www.juridicas.unam.mx

https://biblio.juridicas.unam.mx/bjv

único, indivisible, distinto de los otros seres, que tiene como suyo naturalmente los bienes que la constituyen primariamente: su acto de ser y su naturaleza. Bienes que en razón de la naturaleza humana son comunes a los seres humanos, pero que por tenerlos cada quien como lo suyo y por ser inseparables de la persona no pueden ser considerados como idénticos. Estos bienes o iura son los auténticos derechos naturales de la concepción clásica.

\section{La recuperación de la juridicidad natural de la persona}

Es cierto, por tanto - como dice Vittorio Mathieu - que los derechos humanos exigen como hipótesis necesaria aceptar que el hombre es sujeto de derechos. ${ }^{21}$ Esta hipótesis es válida, pero no es suficiente, porque no tendría sentido alguno afirmar que los derechos humanos son anteriores a la ley positiva, y sostener, en igual forma, que esa ley es la que determina quién es el sujeto de los derechos humanos, sólo puede haberlos —lo dice muy bien Spaemann - en el supuesto de que nadie esté capacitado para juzgar quién es ese sujeto de derechos. ${ }^{22}$ Pues bien, si no se acepta que la persona es sujeto de derechos con precedencia a la ley positiva, no puede afirmarse que tiene derechos anteriores a esa ley. El supuesto fundamental para la existencia de los derechos humanos es la juridicidad natural de la persona, cuyo contenido es tener derechos inherentes. Esta juridicidad y estos derechos se predican de la persona, de su ser, de su dignidad.

Dignidad que no se reduce a la superioridad que tiene el hombre respecto de otros seres, sino que se predica primaria y primordialmente del ser de la persona. Se trata de una dignidad no relativa, sino absoluta, ${ }^{23}$

21 Mathieu, Vittorio, "Prolegómenos a un estudio de los derechos humanos desde el punto de vista de la comunidad internacional", Los fundamentos de..., cit., p. 35.

22 "Pues la noción de derecho humano indica precisamente que el hombre no se convierte en miembro de la sociedad humana mediante una captación realizada sobre la base de determinadas características, sino en virtud del propio derecho. En virtud del propio derecho sólo puede significar: en virtud de su pertenencia biológica a la especie homo sapiens. Cualquier otro criterio convertiría a unos en jueces sobre los otros. La sociedad humana se convertiría en un closed shop y la noción de derecho humano quedaría eliminada de raíz. Sólo cuando el hombre es reconocido como persona sobre la base de lo que es simplemente por naturaleza, puede decirse que el reconocimiento se dirige al hombre mismo y no a alguien que cae dentro de un concepto que otros han convertido en criterio para el reconocimiento. Como es natural, de aquí se deduce también que todo límite temporal para su reconocimiento inicial como hombre es convencional, y, por lo mismo tiránico". Spaemann, Robert, "La naturaleza como instancia moral de apelación", El hombre: inmanencia y trascendencia, Actas de las XXV Reuniones Filosóficas Universidad de Navarra, Pamplona, Servicio de Publicaciones de la Universidad de Navarra, 1991, vol. I, p. 66.

23 Aquino, Tomás de, Suma Teológica, I, q. 42, art. 4 ad. 2. 
Este obra forma parte del acervo de la Biblioteca Jurídica Virtual del Instituto de Investigaciones Jurídicas de la UNAM www.juridicas.unam.mx

https://biblio.juridicas.unam.mx/bjv

que se predica de toda persona y de toda la persona, tanto de su acto de ser como de su naturaleza. Si no se acepta esta dignidad de carácter absoluto no puede reconocerse que toda persona en tanto que es igualmente digna tenga naturalmente los mismos derechos. La dignidad de la persona es la base de la igualdad en derecho, porque todos los seres humanos son sujetos de derechos con la misma intensidad y dignidad. Ésta es, a su vez, la razón para que los derechos humanos sean universales, se prediquen no respecto de algunos hombres, sino de todos los hombres. No hay hombres más dignos que otros, porque no hay una dignidad ontológica mayor en unos hombres que en otros, precisamente, porque nadie es más o menos persona que otro. ${ }^{24}$

Esa dignidad absoluta u ontológica es de cada persona. No debe olvidarse que el nombre de persona apunta directamente a lo individual y a lo singular, al alguien concreto que tiene una naturaleza que, en el caso del hombre, es la naturaleza humana. El ser humano no es sólo naturaleza, physis, como lo concibieron los griegos, sino también persona. Todos los seres humanos tenemos la misma naturaleza, pero no todos somos la misma persona, porque este término es irreductible a lo común. Por esto mismo, nadie es persona por otro ni nadie es en la persona de otro.

La incomunicabilidad de la persona consiste en ser una y distinta y lo es en tanto en cuanto ella participa plenamente del ser, intensidad de ser que la sitúa en otro orden del ser. ${ }^{25}$ Ese modo de ser más perfecto se explica porque la persona es el ser espiritual que domina su propio ser, no puede ser dominada por nadie, por ser enteramente ella misma. La intensidad del acto de ser de la persona es tal que es un acto único, irrepetible e irreemplazable. La persona por esa perfección no tiene la posibilidad de hacerse común, de fusionarse o confundirse con otros seres, porque su acto de ser es tan intenso que no cambia ni se transforma, permanece. Para decirlo con una terminología propia del mundo del derecho, la persona no es alieni iuris, sino sui iuris, es un ser libre. La libertad es manifestación de la dignidad del ser personal, es expresión del dinamismo del

24 Sobre el tema de la dignidad $c f r$., Hervada, Javier, Lecciones propedéuticas..., cit., pp. 447 y ss. Spaemann, Robert, "Sobre el concepto de dignidad humana", Lo natural y lo racional, Madrid, Rialp, 1981, p. 89. En igual forma, nuestros libros: El concepto jurídico de persona, Pamplona, Eunsa, 1989, pp. 433 y ss.; El concepto de persona y los derechos humanos, Bogotá, Ediciones Universidad de la Sabana, 1991, así como nuestro artículo "El respeto a la dignidad de la persona y los derechos humanos en la Constitución Política de Colombia", Díkaion, Revista de la Facultad de Derecho de la Universidad de la Sabana, núm. 3, 1994, pp. 25 y ss.

25 Hervada, Javier, Lecciones propedéuticas..., cit., p. 442. 
Este obra forma parte del acervo de la Biblioteca Jurídica Virtual del Instituto de Investigaciones Jurídicas de la UNAM www.juridicas.unam.mx

https://biblio.juridicas.unam.mx/bjv

ser, que permite que cada persona se autodetermine, sea el origen de sus propios actos.

El dominio ontológico en la persona es, en igual forma, un dominio moral y jurídico. Moral porque la persona, al actuar, lo hace porque tiene capacidades y potencialidades de permanecer en el ser. Sus actos, los actos propios, no le son dados, no son algo impuesto; son el fruto de una decisión libre, que es posible porque la persona es un ser espiritual que puede prever con anticipación aquello que quiere hacer. Esos actos son de la persona, emanan de ella, son lo propio, o, si se observa desde la consideración del otro, lo suyo. Estos actos, por ser originales de la persona, pueden imputársele a ella, y en cuanto tal, generar responsabilidad. La persona responde de lo que actúa, de lo que ella originalmente pone en cada una de sus acciones. Acciones que tienen origen en el ser, que no se predican de todos sino de un alguien concreto. La incomunicabilidad de la persona, la individualidad de cada quien hace que aquello que es suyo tenga un carácter personal, que no sea lo del otro.

La incomunicabilidad de la persona no es aislamiento o soledad porque si bien ella es el alguien que tiene intimidad, también es el alguien que originariamente está relacionado con otros. La persona, sin hacerse común, sin fusionarse y sin confundirse, se comunica con otros; esa comunicación en la alteridad es la base de la sociedad, que supone esa alteridad en la que la persona permanece en su ser. La sociedad se da en el mismo ser personal, no en tanto que la persona sea meramente capaz, sino, precisamente, por estar relacionada naturalmente, por ser socia. No puede, por tanto, la sociedad, absorber a la persona, desconocer su dignidad ni afectarla en su ser. La socialidad como perfección constitutiva de la persona también es esencial para que el derecho exista, porque las relaciones jurídicas se generan y se desarrollan en el ámbito de la comunicación personal, que es posible por la libertad. Al tener cada persona lo suyo, lo que le es propio, puede darse la unión en lo que es común, lo que es como lo de uno. Pues bien, lo propio, expresión del ser y del deber ser de la persona, es, en el ámbito social, lo que se le debe, aquello que en el acto de justicia debe darse o reconocerse a otro. Lo propio, lo suyo, hace posible que se dé la vida social. En este sentido, los bienes constitutivos de la persona son la base esencial de la conformación de la sociedad y de su organización política, son auténticos derechos constitucionales, si se entiende la Constitución en sentido material, o derechos preconstitucionales, si se concibe la Constitución en su simple aspecto formal. 
Este obra forma parte del acervo de la Biblioteca Jurídica Virtual del Instituto de Investigaciones Jurídicas de la UNAM www.juridicas.unam.mx

https://biblio.juridicas.unam.mx/bjv

Los derechos humanos recuperan la juridicidad natural de la persona. Ella aparece ante los demás como titular de derechos y deberes, portadora de bienes que por otros le son debidos. Se advierte así un quiebre con la concepción positivista que considera como única fuente del derecho la ley que surge del Estado. Esta recuperación es tan significativa que replantea la noción misma de derecho, ${ }^{26}$ porque si los derechos humanos son auténticos derechos y si éstos no surgen del Estado, el derecho, cualquiera que él sea, no tiene una fuente meramente estatal. La realidad jurídica no es, por tanto, una realidad meramente histórica, también es una realidad natural que se funda en la dignidad de la persona. Recuperar el núcleo jurídico inherente a la persona es fundar los derechos humanos en la misma dignidad de la persona, porque sin referencia a esa juridicidad natural los derechos humanos no podrían ser considerados como inherentes al ser humano ni tampoco como derechos.

\section{La recuperación del ser debido y exigitivo de la persona}

Si los derechos humanos son auténticos derechos y no meras valoraciones ni ideales a alcanzar ni postulados filosóficos o éticos exigen el respeto del bien que se debe. El derecho, también los derechos humanos, suponen la existencia de deberes. Sin el deber, el derecho no tendría un carácter vinculante, no implicaría la posibilidad de exigir a otro el cumplimiento de una acción necesaria respecto a lo debido. Pues bien, los derechos humanos también recuperan la noción de deber, porque ellos mismos son lo debido, lo que respecto a otros se debe dar, respetar o proteger.

La raíz del deber está, como la del derecho, en la dignidad de la persona humana. El ser personal comporta un merecimiento, una exigencia que se traduce en que los actos que realiza respecto de sí misma o respecto de otros, actos que deben adecuarse a las exigencias de su ser. Si la dignidad dice relación al ser también comporta un deber ser, no extraño al mismo ser, sino expresión de la eminencia y de la intensidad del ser personal. Esas acciones de merecimiento son necesarias, no por razón de coacción, sino por razón de fin.

El ser humano, como ser finito que tiene un ser intenso, tiende a una plenitud, ya no dada sino alcanzada. La persona humana es, pero su ser le

26 Hervada, Javier, "Problemas que una nota esencial de los derechos humanos plantea a la filosofía del derecho", Persona y Derecho, IX, 1982, pp. 243-256. Artículo publicado en la obra del mismo autor: Escritos de derecho natural, Pamplona, Eunsa, 1986, pp. 427 y ss. 
Este obra forma parte del acervo de la Biblioteca Jurídica Virtual del Instituto de Investigaciones Jurídicas de la UNAM www.juridicas.unam.mx

https://biblio.juridicas.unam.mx/bjv

exige ser mejor, le llama a una plenitud de ser; sus tendencias e inclinaciones naturales le ordenan a obtener unos fines que no son extrínsecos a la persona, sino que, en igual forma, son inherentes a ella. De esta forma, se interrelaciona la dignidad ontológica, eminencia del ser, con la dignidad moral, eminencia relativa a los demás por el obrar recto, configurador de las virtudes. El fin es constitutivo de la persona, en la forma de ordenación a la perfección; por ello, todo ser humano tiene tendencialmente en sí la perfección como fin. La plenitud del ser de la persona se traduce en el deber ser, que no podría darse sin un ser exigente, llamado a la plenitud. Su ser es, propiamente, un ser debido y exigitivo. Si el fin tiene relación con el bien, todo deber ser, en tanto referido al fin, es para la persona un bien.

El carácter exigente de la persona se traduce moral y jurídicamente en acciones que le son debidas y en acciones que no le pueden ser debidas, porque son contrarias a las exigencias de su ser personal. Así, por ejemplo, la vida de la persona exige permanecer en el ser; todo aquello que altere su permanencia en el ser afecta de manera directa la dignidad de la persona, en su ser y en su deber ser. Los derechos humanos, en tanto expresión de ese ser debitorio y de ese ser exigente que es la persona, no pueden lesionar ni afectar ese orden del ser ni del deber ser. Para decirlo de manera positiva, los derechos humanos son la expresión jurídica de la dignidad de la persona, dignidad que tiene relación con el ser y con los fines. Fuera del orden del ser y de los fines no puede haber derecho que se cualifique como humano, sólo injusticia y en cuanto tal desconocimiento de la dignidad de la persona.

El derecho y el deber tienen relación con el bien. Derecho y deber son auténticos bienes referidos a un fin. Uno y otro tienen carácter teleológico; mediante ellos no sólo la persona es mejor, sino en tanto que se cumplen hacer mejor, más justa y más humana la sociedad. Derecho y deber se fundan en la finalidad a la cual está ordenada la persona; lo que les otorga el carácter de buenos o de justos es, precisamente, el ser y el fin de la persona. Así, debe afirmarse que los derechos humanos se tienen no sólo por ser persona, sino para ser mejor persona, y en tanto cada quien es mejor se hace mejor la sociedad.

Esta relación entre la persona y la sociedad debe advertirse cada más vez con más énfasis porque los derechos que tiene la persona son deberes respecto de los demás, por ende, de la sociedad. Además, porque la sociedad, al estar conformada por personas, debe contribuir a que esos dere- 
chos se respeten; de ser ello así, no sólo la persona, sino la sociedad, serán mejores.

\section{CONCLUSIÓN}

Habrá que reconocer que los derechos humanos, como expresión dinámica de la dignidad de la persona humana, son algo más que lo que quiere cierto humanismo, que lleva a un relativismo y permisivismo, son las manifestaciones de las exigencias que surgen de su propio ser. Así, pues, en esta época de crisis moral, los derechos humanos deben reivindicarse como una recuperación, no sólo teórica, sino también práctica, de la dignidad de la persona humana. 


\title{
EL DERECHO A LA VIDA EN LA SISTEMÁTICA DE LOS DERECHOS HUMANOS
}

\author{
Carlos I. MASSINI CORREAS
}

\section{A la memoria de Raúl Echauri}

\begin{abstract}
SUMARIO: I. Precisiones preliminares. II. Los derechos humanos. III. El contenido de los derechos. IV. El derecho a la inviolabilidad de la vida y la noción de persona. V. Un derecho absoluto. VI. El derecho a la inviolabilidad de la vida en la sistemática de los derechos humanos. VII. El menosprecio de la vida. VIII. Conclusiones.
\end{abstract}

\section{PRECISIONES PRELIMINARES}

Se nos ha solicitado, por parte de los organizadores de este simposio, ${ }^{1}$ que expongamos acerca del derecho a la vida y de su posición dentro de una concepción sistemática de los derechos humanos; ahora bien, antes de comenzar propiamente con el desarrollo del tema, aparece como conveniente efectuar algunas breves precisiones liminares, que hagan posible la mejor comprensión de las nociones que hemos de utilizar en los análisis subsiguientes. Estas precisiones son especialmente pertinentes en un tema como el de los derechos humanos, en el que la parcialidad ideológica, la sobrecarga retórica y la inflación literaria, han contribuido especialmente a oscurecerlo y tornarlo cada vez más confuso.

La primera de estas precisiones se refiere a la pertinencia de la expresión misma "derecho a la vida", ya que ella parece no corresponder a la verdadera estructura de la relación de derecho subjetivo. En efecto,

1 Nos referimos al Simposio Internazionale sull "Evangelium Vitae" e il Diritto, realizado en la ciudad del Vaticano, entre los días 23 y 25 de mayo de 1996, organizado por el Pontificio Consiglio per l'Interpretazione dei Testi Legislativi. 
Este obra forma parte del acervo de la Biblioteca Jurídica Virtual del Instituto de Investigaciones Jurídicas de la UNAM www.juridicas.unam.mx

https://biblio.juridicas.unam.mx/bjv

todo derecho supone una relación de cuatro términos: i) un sujeto titular del derecho; ii) un obligado a cumplir con el deber correlativo del derecho; iii) una prestación u obrar humano que es el objeto del derecho, y iv) un fundamento justificatorio de ese derecho, que es la razón formal por la que él existe y es, por lo tanto, debido. ${ }^{2}$ John Finnis, en su notabilísimo libro Natural Law and Natural Rights, sostiene que la relación de derecho es de tres términos, excluyendo al fundamento como componente estricto de la relación. ${ }^{3}$ De todos modos, y a los efectos de lo que ahora nos interesa, lo relevante es destacar el hecho de que para que exista un derecho, es necesaria la presencia de, al menos, dos sujetos y una prestación.

En el caso del llamado "derecho a la vida", esta prestación no puede consistir sino en una conducta de respeto y compromiso para con la vida humana, propia o ajena. Esto significa que si adecuáramos estrictamente la designación a la estructura del derecho, sería preciso hablar de "derecho a no ser muerto injustamente" o a la "intangibilidad" o "inviolabilidad de la vida", ya que el objeto propio y formal de ese derecho consiste en un obrar humano de respeto y reverencia a la "vitalidad" o carácter viviente del hombre. No obstante esto, es posible hablar, en sentido metonímico, ${ }^{4}$ de un "derecho a la vida", toda vez que la permanencia e integridad de la vida humana es la finalidad y el efecto necesario de la acción de respeto o compromiso en que consiste el objeto de ese derecho. Pero a pesar de la legitimidad retórica de esa metonimia, vamos a hablar en lo sucesivo de "derecho a la inviolabilidad de la vida", en razón de que esa denominación precisa mejor el objeto del derecho y disminuye la posiblidad de malentendidos.

La segunda de las precisiones a que haremos referencia hace alusión a que cuando hablamos aquí de "la vida" estamos designando precisa y exclusivamente a la vida humana, ${ }^{5}$ es decir, la de los individuos pertenecientes a la especie homo sapiens, y no a las formas infrahumanas de vida animal o vegetal (o aun mineral, ya que Robert Nash habla de un "derecho de las rocas"). ${ }^{6}$ Esta precisión resulta oportuna, toda vez que existe

2 Cfr. Gewirth, A., “Are There Any Absolute Rights?", Theories of Rights, J. Waldron (comp.), Oxford, Oxford U. P., 1984 , p. 95.

3 Vid. Finnis, John, Natural Law and Natural Rights, Oxford, Clarendon Press, 1984, pp. 201 y ss.

4 Sobre la metonimia, vid. Reboul, Olivier, La rhétorique, París, PUF, 1990, pp. 43-44.

5 Sobre la noción de "vida" y de "vida humana" que utilizamos en este texto, vid. Sanguineti, J. J., voz "Vida", Gran Enciclopedia Rialp, Madrid, 1981, t. XXIII, pp. 511-514.

6 Vid. Nash, R., "¿Tienen derechos las rocas? Pensamientos sobre la ética del medio ambiente", en M. Mooney y F. Stuber (comp.), Los humanistas y la política, México, FCE, 1984, pp.132 y ss. 
Este obra forma parte del acervo de la Biblioteca Jurídica Virtual del Instituto de Investigaciones Jurídicas de la UNAM www.juridicas.unam.mx

https://biblio.juridicas.unam.mx/bjv

una importante corriente de pensamiento que sostiene la existencia de derechos estrictos de los que son titulares entes no humanos, como los animales, las plantas y los ríos. ${ }^{7}$ Esta tesis supone: i) un desconocimiento palmario de la naturaleza del fenómeno jurídico; ii) una visión distorsionada —o al menos caprichosa- del universo, y iii) una decidida posición antihumanista, que termina negando al hombre sus derechos más fundamentales — entre ellos a la inviolabilidad de su vida - en beneficio de una supuesta conciencia ecológica entendida de modo absoluto. A este tema nos hemos referido en otros lugares, a los que nos remitimos en razón de la brevedad. ${ }^{8}$

\section{LOS DERECHOS HUMANOS}

Hechas las pertinentes aclaraciones y precisiones, vamos a entrar en el desarrollo del tema exponiendo las notas fundamentales de la noción de derechos humanos, para encuadrar luego en su sistemática al "derecho a la inviolabilidad de la vida". En el acápite precedente pusimos de relieve que la existencia de "derechos" supone cuatro elementos en necesaria vinculación: dos sujetos, una prestación y un fundamento. En el caso de este último, es necesario distinguir entre un fundamento próximo y un fundamento remoto: fundamento remoto o mediato es siempre un principio práctico, primero o muy próximo a él; fundamento próximo o inmediato es la razón precisa, objetiva y formal por la que alguien es titular de un derecho determinado: esto es lo que técnicamente se denomina "título" de ese derecho. Ahora bien, la noción de derechos humanos hace referencia especial al cuarto de estos elementos: el fundamento de los derechos, y denota la existencia de ciertos derechos cuyo fundamento exclusivo es la dignidad personal de todo ente humano. Dicho en otros términos, se trata de ciertos derechos cuyo fundamento o justificación objetiva, tanto mediata como inmediata, se vincula al carácter personal del viviente humano y a la dignidad que corresponde a toda persona. ${ }^{9}$

7 Vid. Singer, P., "Not for Humans Only: The Place of Nonhumans in Environmental Issues", en K. E. Goodpaster y K. M. Sayre (ed.), Ethics \& The Problems of the 21 st. Century, Indiana, U. of Notre Dame Press, 1979, pp. 196 y ss.

8 Vid. Massini Correas, C. I., "Dignidad humana y derecho ambiental", en Actas de las XXV Jornadas Chilenas de Derecho Público, t. I, Valparaíso, EDEVAL, 1995, pp. 125-133; también: Ballesteros, J., Ecologismo personalista, Madrid, Tecnos, 1995.

9 Vid. Massini Correas, C. I., Filosofía del derecho, Buenos Aires, Abeledo-Perrot, 1994, pp. 102 y ss. 
Este obra forma parte del acervo de la Biblioteca Jurídica Virtual del Instituto de Investigaciones Jurídicas de la UNAM www.juridicas.unam.mx

Si intentamos explicitar lo antedicho de modo sumario, podemos afirmar que la justificación primera de cualquier derecho humano radica en un principio normativo, que no es sino una determinación del primer principio práctico según el cual "el bien ha de hacerse y el mal evitarse", ${ }^{10}$ y que puede ser formulado del siguiente modo: "todo hombre debe salvaguardar el carácter de persona de todo hombre". ${ }^{11}$ Este principio es autoevidente, ya que se conoce de modo directo no bien se comprende el significado de, por una parte, la locución "persona" y, por la otra, de la locución "salvaguardar": la persona, por su intríseca dignidad, aparece inmediatamente como algo a respetar y promover.

Desde el punto de vista de la filosofía práctica — ha escrito Millán Puelles - la dignidad ontológica de la persona humana posee una significación esencial: la de constituir el fundamento [...] de los deberes y derechos básicos del hombre [...], ya que hay un derecho general en el cual se resumen los diversos derechos de toda persona humana: el de ser tratados cabalmente como personas humanas, no en virtud de razones o motivos particulares, sino en función de la dignidad ontológica del ser sustancial del hombre. ${ }^{12}$

Por su parte, el fundamento inmediato o título de todo derecho humano radica precisamente en la condición de persona que reviste todo ente que pertenece a la especie humana; esto se hace evidente no bien se consideran las principales declaraciones de derechos $\mathrm{y}$, en general, todos aquellos textos en los que se habla o discute acerca de los derechos humanos: en efecto, allí se reconocen esos derechos a las personas humanas sin exigirse más determinación que la de ser personas y cuando aparece requerida alguna calificación especial: "mujer embarazada", "persona en edad núbil", "padres", etcétera, es porque esa calidad se vincula directamente con alguna de las dimensiones centrales del desarrollo o perfeccionamiento de la "personeidad". Por otra parte, también resulta evidente que la existencia de los derechos humanos no depende esencialmente de su reconocimiento por los ordenamientos jurídico-positivos: ellos existen, es decir, son exigibles, sea que se encuentren positivados o no; lo que es

10 Sobre la inteligencia de este principio, vid. Armstrong, R., Primary and Secondary Precepts in Thomistic Natural Law Teaching, The Hague, M. Nijhoff, 1966.

11 Massini Correas, C. I., Filosofía..., cit., p. 119.

12 Millán Puelles, A., Léxico filosófico, Madrid, Rialp, 1984, pp. 465-466; sobre la noción de dignidad de la persona humana, en especial desde la perspectiva kantiana, vid. Mandonça, W. P., “Die Person als Zweck an sich”, Kant Studien, 84 Jahrgung, Heft 2, 1992, pp. 167-184. 
más aún, existen y son exigibles aun cuando un determinado ordenamiento positivo los niegue o los desconozca. ${ }^{13}$ Por todo esto, es posible concluir que derechos humanos son todos aquellos derechos subjetivos cuyo título radica en la personeidad de su sujeto activo, o en alguna de las dimensiones básicas del desenolvimiento de esa personeidad y de los que se es titular, los reconozca o no el ordenamiento jurídico positivo y aun cuando éste los niegue. ${ }^{14}$

\section{EL CONTENIDO DE LOS DERECHOS}

Establecido de modo somero qué cosa son los derechos humanos, queda por determinar cúales son ellos, es decir, establecer precisamente a qué derechos puede atribuirse estrictamente el calificativo de "humanos". Dicho de otro modo, una vez establecido el constitutivo formal de los derechos humanos: su fundamentación mediata e inmediata en la dignidad personal de todo ente humano, queda por precisar su contenido o aspecto material, sin el cual la fórmula "derechos humanos" resultaría una forma ideal vacía. ${ }^{15}$ Se han realizado numerosos ensayos de respuesta a la pregunta por el contenido de la noción de derechos humanos, entre los cuales escogeremos el que aparece como más sólido y acertado: el propuesto por la Nueva Escuela de Derecho Natural, ${ }^{16}$ y en especial por John Finnis, para quien la materia de los derechos humanos viene dada por los bienes humanos básicos. En efecto, para este profesor de Oxford, el proceso de especificación y demarcación de los derechos supone necesariamente tener en consideración algún patrón o jerarquía de patrones de aquello en que consiste la perfección humana, es decir, alguna concepción del bien humano, del desarrollo individual en la vida social, a los fines de seleccionar aquella especificación de los derechos y deberes que tienda a favorecerla o a impedir su frustración. ${ }^{17}$ Sin esta referencia, desaparecería todo criterio válido de especificación, y cualquier derecho po-

13 Vid. Hervada, J., "Problemas que una nota esencial de los derechos humanos plantea a la filosofía del derecho", Escritos de derecho natural, Pamplona, EUNSA, 1986, pp. 427-428.

14 Massini Correas, C. I., Filosofía..., cit., p. 102.

15 Vid. Serna, P., "La dignidad de la persona como principio de derecho público", en AA.VV., Actas de las XXV Jornadas de Derecho Público, Valparaíso, EDEVAL, 1995, pp. 363-386.

16 Sobre esta Escuela, vid. Gahl, R., Practical Reasoning in the Foundation of Natural Law According to Grisez, Finnis and Boyle, Romae, Athenaeum Romanum Sanctae Crucis, 1994.

17 Finnis, J., Natural Law..., cit., pp. 218-219. 
Este obra forma parte del acervo de la Biblioteca Jurídica Virtual del Instituto de Investigaciones Jurídicas de la UNAM www.juridicas.unam.mx

dría pertenecer a cualquiera, en cualquier o en ninguna circunstancia, y así sucesivamente.

La corriente central del pensamiento anglosajón contemporáneo llama a esta doctrina "perfeccionismo" 18 y la ataca sosteniendo que resulta injusto preferir una cierta concepción del desarrollo humano e intentar materializarla en la legislación y las costumbres, toda vez que ello significaría tratar con desigual consideración y respeto a aquellos miembros de la comunidad que no comparten aquella concepción, y cuya autonomía se vería restringida por la legislación y las disposiciones jurídicas que la reflejen. ${ }^{19}$ Pero este argumento, no obstante su difusión, resulta injustificado y se refuta a sí mismo; efectivamente,

quienes lo sostienen - escribe Finnis - prefieren de hecho una concepción del bien humano, según la cual la persona tiene un título a ser tratada con igual consideración y respeto y la comunidad actúa incorrectamente negándoselo; más todavía, ellos actúan tratando de abolir la legislación restrictiva elaborada por sus oponentes. Pero aquellos que actúan y argumentan así ¿tratan necesariamente con desigual consideración y respeto a aquellos a cuyas preferencias y legislación se oponen? Si es así, entonces sus propios argumentos y acciones son en sí mismos igualmente injustificados y no otorgan base alguna para ciertas preferencias o conductas políticas. Si no es así [...], entonces tampoco lo hacen aquellos a quienes se oponen. ${ }^{20}$

Esta afirmación de Finnis es estrictamente cierta, en razón de que los autores que dicen oponerse al "paternalismo", han de partir también —necesariamente - de alguna concepción del bien humano para fundar $\mathrm{u}$ oposición al accionar de sus oponentes. Esta concepción es la concepción ultraindividualista, que considera al hombre como plenamente autónomo y absolutamente libre, capaz de crear racionalmente las normas y paradigmas de su propio obrar. Pero al suponer esta concepción del hombre y del bien humano, bien al que conciben como radicando en el mero ejercicio de la autonomía individual, los "liberals" caen también inevitablemente en un "paternalismo" de sentido contrario, que se concreta en la pretensión de orientar la legislación, las decisiones de los jueces y las políticas

18 Acerca de la noción de "perfeccionismo", vid. Hurka, T., Perfectionism, New York, Oxford U. P., 1993.

19 Sobre esta perspectiva "liberal" del derecho y de los derechos, vid. George, R. P., Making Men Moral. Civil Liberties and Public Morality, Oxford, Clarendon Press, 1995.

20 Finnis, J., Natural Law..., cit., pp. 221-222. 
Este obra forma parte del acervo de la Biblioteca Jurídica Virtual del Instituto de Investigaciones Jurídicas de la UNAM www.juridicas.unam.mx

https://biblio.juridicas.unam.mx/bjv

del gobierno en el sentido de la promoción y difusión de ese modelo humano. ${ }^{21}$

Volviendo ahora al problema de la determinación del contenido de los derechos humanos, que no es sino el de la delimitación de los perfiles de aquel modelo de bien humano, resulta que lo que la razón humana descubre, con la mediación de la experiencia, ${ }^{22}$ no es directamente una visión integral de la perfección humana, sino más bien las diversas formas de concreción o realización de ese bien humano.

Existen ciertos bienes — escriben Boyle, Grisez y Finnis- $v$. gr. el conocimiento de la verdad y la vida en la amistad, cuya prosecución parece promover por sí misma a las personas y mantenerlas unidas. Bienes como éstos son aspectos intrínsecos —es decir, partes reales- de la completud o realización integral de las personas. Llamamos a estos aspectos intrínsecos de la perfección personal "bienes humanos básicos": básicos no para la mera supervivencia, sino para la perfección humana. ${ }^{23}$

Ahora bien, esos bienes humanos básicos no son los objetivos definidos de cierta actividad humana, como lo podría ser la rendición del enemigo en una batalla o el incremento de la producción anual de granos; se trata más bien de bienes que trascienden a cualquiera de sus determinaciones particulares, que van más allá de su realización parcial, cuya participación en una situación concreta no los agota, que son realizables de infinidad de maneras diversas, cada una de las cuales no es sino una concreción parcial de una perfección que la sobrepasa. Un determinado acto de goce estético, $v$. gr., no agota el bien básico de la experiencia estética, sino que es sólo una forma particular de participación en él. Estos bienes humanos básicos orientan la conducta de los hombres proveyendo las razones para escoger y obrar en ciertas y determinadas direcciones, direcciones que se ordenan a la realización de alguna forma de participación en un bien humano básico.

Ahora bien: ¿cuáles son esos bienes? Finnis enumera siete en Natural Law and Natural Rights: vida, conocimiento, juego, experiencia estética,

21 Vid. Massini Correas, C. I., "Realismo y derechos humanos", Atlántida, núm. 1, Madrid, 1990, pp. 55-63.

22 Sobre la noción de experiencia en el campo ético, vid. Millán Puelles, A., La libre aceptación de nuestro ser, Madrid, Rialp, 1994, pp. 73 y ss.

23 Finnis, J., Boyle, J. y Grisez, G., Nuclear Deterrence, Morality and Realism, Oxford, Clarendon Press, 1987, p. 277. 
Este obra forma parte del acervo de la Biblioteca Jurídica Virtual del Instituto de Investigaciones Jurídicas de la UNAM www.juridicas.unam.mx

https://biblio.juridicas.unam.mx/bjv

sociabilidad o amistad, razonabilidad práctica y religión. ${ }^{24}$ En Nuclear Deterrence, Morality and Realism, escrito en colaboración con Grisez y Boyle, Finnis ofrece una enumeración parcialmente diferente; allí, los bienes básicos son seis: 1) vida (su mantenimiento y trasmisión, salud y seguridad); 2) conocimiento y experiencia estética; 3) excelencia en el trabajo y en el juego; 4) amistad, paz y fraternidad; 5) paz interior, autointegración y autenticidad, y 6) armonía con los más amplios ámbitos de la realidad, en especial con Dios y con el entorno natural. ${ }^{25}$

Estos bienes fundan y especifican los derechos humanos en razón de que la realización de los bienes básicos es una obra de mancomún, estrictamente colectiva y progresiva, que se realiza gradualmente en el tiempo a través de la convivencia social. Es más, la perfección humana no se realiza en comunidad por un mero accidente o por azar, sino que esa perfección es el propósito u objetivo mismo por el que los hombres se reúnen en sociedad. Y esta inevitable coexistencialidad en la realización de los bienes propiamente humanos, es la que hace necesaria la existencia de toda la trama de derechos y deberes que ordenan el intercambio de prestaciones que es preciso para la existencia y la buena vida en la comunidad política. ${ }^{26}$ Por lo tanto, sin coexistencia, sin derecho que determine lo debido a cada uno y sin derechos por medio de los cuales exigir eso que es debido, no es siquiera pensable la concreción o realización de los bienes humanos básicos; de aquí que sean estos bienes los que otorguen justificación racional y contenido a los derechos; en primer lugar, a los más fundamentales de entre ellos: los llamados derechos humanos.

Cada derecho humano se ordena, por lo tanto, a la realización de uno o varios bienes humanos básicos y recibe a su vez de éstos su justificación objetiva; así, el derecho a la educación tiene por contenido y fundamento el bien básico del conocimiento, que perfecciona la dimensión racional del hombre; el derecho a trabajar, recibe su fundamentación y alcance del bien humano de la excelencia en el trabajo en cuanto realización humana, expresión de la dimensión cultural del hombre; y en lo que nos interesa aquí especialmente, el derecho a la inviolabilidad de la vida tiene su base racional en el bien básico de la vida, como modo de existir autónomo propio de los entes humanos, que se manifiesta a través de la

26 Vid. Cotta, S., "La coexistencialidad ontológica como fundamento del derecho", Persona y Derecho, Pamplona, núm. 9, 1982, pp. 13-18. 
Este obra forma parte del acervo de la Biblioteca Jurídica Virtual del Instituto de Investigaciones Jurídicas de la UNAM www.juridicas.unam.mx

https://biblio.juridicas.unam.mx/bjv

inclinación a la supervivencia y sin el cual los restantes bienes quedan sin sujeto y, por lo tanto, sin sentido perfectivo y completivo. ${ }^{27}$

\section{EL DERECHO A LA INVIOLABILIDAD DE LA VIDA Y LA NOCIÓN DE PERSONA}

El derecho a la inviolabilidad de la vida, por lo tanto, tiene su fundamento o justificación racional en la eminente dignidad de la persona humana, y su contenido o materia está dado por el respeto al bien básico de la vida en cuanto modo propio de la existencia de los entes humanos. En otras palabras, la prestación que corresponde a este derecho consiste en una conducta: acción u omisión, de respeto y salvaguarda al bien básico de la vida. Establecida a grandes rasgos la naturaleza del derecho a la inviolabilidad de la vida, corresponde precisar tres cuestiones, que resultan centrales para la dilucidación del carácter y alcances de este derecho: i) la cuestión de su duración, es decir, del origen temporal y de la extinción de este derecho; ii) la de su carácter absoluto o prima facie, y iii) la de su ubicación en la sistemática de los derechos humanos.

Respecto de la primera de las cuestiones, la respuesta del sentido común es que ese derecho ha de perdurar durante todo el tiempo de persistencia del bien que está destinado a proteger, es decir, la vida humana, y por lo tanto, desde la concepción hasta la muerte. Desde el momento mismo en que en un individuo que pertenece a la especie humana se da ese principio intrínseco de movimiento espontáneo en que la vida consiste, ${ }^{28}$ debe existir también el derecho a que no se lo prive de ella injustamente. Pero sucede que la respuesta del sentido común no es, ni mucho menos, aceptada indiscutidamente; en efecto, para toda una corriente del pensamiento actual, sólo son titulares de este derecho las "personas", cuya noción no es coextensiva con la de entes humanos, ya que existirían entes humanos que no son personas. En este sentido, uno de los referentes indiscutidos de la bioética contemporánea, Tristram Engelhardt, escribe que

no todos los seres humanos son personas, no todos son autorreflexivos, racionales o capaces de formarse un concepto de la posibilidad de culpar o

27 Vid. Walhout, D., "Human Nature and Value Theory”, The Thomist, núm. 44, Washington D.C., pp. 278-297.

28 Cfr. Aquino, Tomás de, Summa Theologiae, I, q. 18, a. 2. Sobre la inteligencia de este texto, vide Verneaux, R., Filosofía del hombre, Barcelona, Herder, 1988, pp. 17-29. 
Este obra forma parte del acervo de la Biblioteca Jurídica Virtual del Instituto de Investigaciones Jurídicas de la UNAM www.juridicas.unam.mx

https://biblio.juridicas.unam.mx/bjv

alabar. Los fetos, las criaturas, los retrasados mentales profundos y los que se encuentran en coma profundo son ejemplos de seres humanos que no son personas. Estas entidades son (sólo) miembros de la especie humana. ${ }^{29}$

Esta neta distinción entre seres humanos y personas no es patrimonio exclusivo de Engelhardt, sino de toda una serie de autores que la han hecho suya y la han defendido con mayor o menor convicción: entre estos autores podemos enumerar a Peter Singer, Michael Tooley, H. J. McCloskey, R. G. Frey, el argentino Martín Farrell y, aunque trata de eludir la cuestión, Ronald Dworkin. ${ }^{30}$ Para todos estos autores, la "personeidad", para utilizar un término de Zubiri, no consiste en un constitutivo esencial del ser humano, no es una dimensión óntica del hombre, sino que es más bien el resultado del ejercicio actual de una serie de facultades o disposiciones, tales como la autoconciencia, la responsabilidad moral, la libertad de movimientos y de elecciones, la capacidad de comunicación, y así sucesivamente, todas las cuales son susceptibles de poseerse en mayor o menor medida.

Esta opinión, que podemos llamar "empirista", ya que hace radicar la personeidad en una serie de datos verificables desde una perspectiva estrictamente empírica, incurre en una evidente falacia, toda vez que confunde ciertas manifestaciones externas con la raíz esencial de esas manifestaciones; utilizando la terminología de Vittorio Possenti, no alcanza a distinguir los caracteres esenciales de un ente de los no esenciales, que son sólo un signo y una consecuencia de los primeros.

Los caracteres y las funciones que pueden crecer, disminuir o faltar - escribe este autor - son por eso mismo no-esenciales. En particular, la privación de una cualidad (v. gr. la vista, la palabra, la conciencia) admite gra-

29 Engelhardt, H. T., The Foundations of Bioethics, New York, Oxford U. P., 1986, p. 107. Vid. en un sentido similar, Hare, R. M., Essays on Bioethics, Oxford, Clarendon Press, 1968 ss.

30 Dworkin, R., en su reciente libro Life's Dominion. An Argument about Abortion, Euthanasia and Individual Freedom, New York, Knopf, 1993, efectúa una distinción entre la "vida en total intensidad", y aquella que no ha alcanzado o ha perdido esa situación; en estos últimos casos, las "criaturas humanas" carecen de intereses propios y por lo tanto de derechos; el feto, v. gr., "no es conciente del dolor hasta una época tardía del embarazo de la madre, ya que su cerebro no se encuentra suficientemente desarrollado hasta entonces", razón por la cual "la decisión acerca de terminar con la vida humana en el embarazo temprano debe ser dejada a la mujer embarazada". Por ello, aunque Dworkin trate de evitar la cuestión de la personeidad de los no nacidos o de los enfermos terminales, aduciendo que se trata de una "cuestión traicionera" por los diversos usos que se da en el lenguaje corriente a la expresión "persona", termina aceptando tácitamente que los no nacidos y todos los que no tienen su "vida en total plenitud" no tienen derechos y, por lo tanto, no son personas; vid. pp. 3-22 y passim. 
Este obra forma parte del acervo de la Biblioteca Jurídica Virtual del Instituto de Investigaciones Jurídicas de la UNAM www.juridicas.unam.mx

https://biblio.juridicas.unam.mx/bjv

dos, lo que no ocurre con las propiedades esenciales. En consecuencia, por el mismo hecho de que la conciencia o los estados psíquicos pueden tener grados, ellos no constituyen una determinación esencial del ser persona. ${ }^{31}$

Dicho en otras palabras: los fenómenos psíquicos, como la autoconciencia, el arrepentimiento o el raciocinio, que sólo aparecen en los entes humanos, aparecen casualmente porque se trata de entes humanos-personas, y esta cualidad no depende de sus manifestaciones externas, psíquicas o no, sino del constitutivo intrínseco por el cual un determinado ente es persona. Es bien claro que un ente no puede llevar a cabo actividades "personales" si previamente él mismo no es persona. Y es persona por una cualidad intrínseca o esencial, que no puede poseerse en grados y que no puede, salvo por una decisión arbitraria, tener un origen y una finalización distinta a la del ente que se constituye como tal por esa esencia. Ha escrito a este respecto Robert Spaemann, que

reducir la persona a ciertos estados actuales — conciencia del yo y racionalidad - termina disolviéndola completamente: ya no existe la persona sino sólo "estados personales de los organismos". Esta doctrina se halla en flagrante contradición con nuestra intuición espontánea más elemental. Es, inclusive, internamente contradictoria, pues los estados personales de conciencia no se pueden describir en absoluto sin recurrir a la identidad entre hombre y persona [...]. Si el hombre fuera un ser vivo que hay que amaestrar, no una persona - concluye Spaemann - no asimilaría (ni desarrollaría, CIMC) las formas de expresión del ser personal. La personalidad es una constitución esencial, no una cualidad accidental. Y mucho menos un atributo que [...] se adquiera poco a poco. Dado que los individuos normales de la especie homo sapiens se revelan como personas por poseer determinadas propiedades, debemos considerar seres personales a todos los individuos de esa especie, incluso a los que todavía no son capaces, no lo son ya o no lo serán nunca, de manifestarlos. ${ }^{32}$

Podemos concluir, por lo tanto, en lo que respecta a esta primera cuestión, que no puede dudarse seria y desinteresadamente de que todo individuo de la especie humana tiene el constitutivo esencial de la "per-

31 Possenti, V., "L'embrione è persona? Sullo statuto ontologico dell'embrione humano", Aprossimazione all'essere, Padova, Il poligrafo, 1995, p. 124.

32 Spaemann, R., “¿Todos los hombres son personas?”, en J. L. del Barco (ed.), Bioética, Madrid, Rialp, 1992, p. 72. Vid. D’Agostino, F., Filosofia del diritto, Torino, Giappichelli ed., 1993, pp. 351 y passim. 
Este obra forma parte del acervo de la Biblioteca Jurídica Virtual del Instituto de Investigaciones Jurídicas de la UNAM www.juridicas.unam.mx

soneidad" o carácter de persona y que, por ello mismo, el derecho a la inviolabilidad de la vida que se sigue necesariamente de ese carácter, pertenece a todo ser humano desde que comienza su existencia con la concepción, hasta que se extingue por la muerte. Todas las demás elucubraciones destinadas a separar conceptualmente las nociones de ser humano y de persona, no son sino construcciones ideológicas destinadas a justificar las diversas formas de violación de ese derecho, en especial aquellas que tienen por destinatario a las más inermes de las personas. ${ }^{33}$

Por otra parte, la determinación más o menos arbitraria del momento en que un ser humano comenzaría a ser "persona" y a ser titular, por lo tanto, del derecho a la inviolabilidad de la vida, tiene como consecuencia necesaria dejar establecido el principio de que la muerte de una persona puede ser moralmente lícita en ciertas circunstancias o dentro de ciertos límites temporales. Y sucede que una vez aceptado ese principio, todos estamos en peligro inminente de ser asesinados, sin ningún cargo de conciencia, por quien considere - y aporte razones acerca de - que los calvos, los argentinos o los que llevan apellido italiano no son titulares del derecho a la inviolabilidad de su vida. Este peligro se agrava aún más cuando esa convicción se extiende a un amplio sector de la sociedad y se transforma en la ideología de quienes detentan el poder social o político. Ha escrito en este sentido Robert Spaemann, que la dignidad del hombre

se fundamenta en el carácter personal del hombre. Pero la inviolabilidad de la persona depende de que a ningún hombre (o grupo de hombres; CIMC) le corresponda juzgar si otro hombre posee o no los rasgos fundamentales de la personalidad. Lo derechos humanos dependen del hecho de que nadie tiene la prerrogativa de definir el círculo de aquellos a quienes corresponden o dejan de corresponder. Esto significa que se fundamentan en el carácter de persona de todo ser humano y que deben reconocerse a todo ser que descienda del hombre y a partir del primer momento de su existencia natural, sin que sea lícito añadir cualquier criterio adicional.

Y concluye que "si la pretensión de pertenecer a la sociedad humana quedara al juicio de la mayoría (o de los científicos, los legisladores, etcétera; CIMC), habríamos de definir en virtud de qué propiedades se posee 
Este obra forma parte del acervo de la Biblioteca Jurídica Virtual del Instituto de Investigaciones Jurídicas de la UNAM www.juridicas.unam.mx

https://biblio.juridicas.unam.mx/bjv

dignidad humana y se pueden exigir los derechos correspondientes. Pero esto sería suprimir absolutamente la idea misma de derechos humanos". ${ }^{34}$

\section{UN DERECHO ABSOLUTO}

La segunda de las cuestiones a dilucidar acerca del derecho a la inviolabilidad de la vida es la de saber si reviste carácter absoluto o inexcepcionable, o bien relativo o prima facie. La cuestión se plantea porque existen toda una serie de autores que reconocen un cierto derecho a la vida a todo ser humano concebido, pero lo consideran como una mero derecho prima facie, es decir, sobrepasable o excepcionable cada vez que consideraciones de utilidad, de interés o de bienestar se opongan a su vigencia. La noción de derechos prima facie es la traspolación -incorrecta, por otra parte - de la noción de deberes prima facie, difundida por sir David Ross en la década de los treinta; para Ross, un deber es prima facie cuando alguna conducta es debida en ciertos respectos, pero no en otros, lo que ocurre — según él— prácticamente en todos los casos de obligación moral; para que una conducta sea obligatoria - sostiene Ross- es necesario que su obligatoriedad prima facie prepondere sobre la no obligatoriedad prima facie de esa misma conducta. ${ }^{35}$

De un modo similar, toda una serie de pensadores de origen anglosajón, sobre todo pertenecientes a la escuela utilitarista, ${ }^{36}$ sostienen que los derechos humanos - o derechos morales, como ellos prefieren llamarlos-, son sólo derechos prima facie, es decir, que pueden ser derogados, sobrepasados o suspendidos en el caso de que su respeto acarree consecuencias dañosas para el deudor o para la sociedad en general. ${ }^{37} \mathrm{Y}$ en lo que respecta al derecho a la inviolabilidad de la vida, esos autores sostienen que si bien es preciso reconocer en principio ese derecho a los concebidos no nacidos, a los retrasados mentales profundos, a los ancianos y a los enfermos terminales, ese derecho puede ser dejado de lado cuando existan circunstancias que hagan difícil o gravoso su cumplimiento.

34 Spaemann, R., Lo natural y lo racional, Madrid, Rialp, 1989, pp. 50 y 109.

35 Vid. Ross, D., Foundations of Ethics, Oxford, Oxford U. P., 1939, cap. IV.

36 Sobre los derechos desde la perspectiva utilitarista, vid. Lyons, D., Rights, Welfare, and Mill's Moral Theory, New York, Oxford U. P., 1994; AA.VV., Utility \& Rights, ed. R. G. Frey, Oxford, Basil Blackwell, 1985, y Massini Correas, C. I., Los derechos humanos en el pensamiento actual, Buenos Aires, Abeledo-Perrot, 1994, pp. 47-81.

37 Vid. Scanlon, T. M., "Rights, Goals and Fairness", en AA.VV.,Theories of Rights, cit., pp. 137-152; asimismo, Lyons, D., “Utility and Rights", ibidem, pp. 110-136. 
Este obra forma parte del acervo de la Biblioteca Jurídica Virtual del Instituto de Investigaciones Jurídicas de la UNAM www.juridicas.unam.mx

https://biblio.juridicas.unam.mx/bjv

En este sentido, Judith Jarvis Thompson acepta que puede reconocerse derecho a la vida al concebido, pero sostiene que, no obstante, existen casos: $v$. gr. cuando el embarazo es producto de una violación, en los cuales ese derecho desaparece. ${ }^{38}$ En un sentido similar, Mary Ann Warren defiende la necesidad de otorgar al feto humano un cierto estatus moral y, por lo tanto, un cierto derecho a no ser muerto, pero que este derecho debe ceder ante el igual o más fuerte de la madre de "desembarazarse" de su hijo. ${ }^{39}$ Finalmente, Martín Farrell afirma que el no nacido, sobre todo después del primer trimeste de vida, tiene un cierto derecho prima facie a no ser muerto, derecho que puede ser desplazado por consideraciones de utilidad, salvo que exista una alternativa que permita respetar ese derecho, respetando al mismo tiempo las razones de utilidad. ${ }^{40}$

El primer problema que se plantea a estas opiniones es que la noción de "derecho prima facie" es intrínsecamente contradictoria; efectivamente, un "derecho" cuyo cumplimiento queda librado a que el obligado no tenga grandes $-\mathrm{O}$ no tan grandes - inconvenientes para realizar la prestación que es su objeto, no puede ser llamado propiamente derecho, sino que se reduce más bien a una mera pretensión, o súplica, o ruego. Correlativamente, es imposible que el sujeto pasivo de un derecho se considere realmente "obligado" a cumplirlo, si sabe que está autorizado a no hacerlo si le resulta inútil, gravoso o molesto su cumplimiento. Nadie puede "tomar en serio" ${ }^{41}$ un derecho que está sujeto a la condición suspensiva de que el deudor pueda no cumplirlo por razones de utilidad o de comodidad.

Como consecuencia, y especialmente en un caso como el que estamos estudiando, no existirá propiamente "derecho" alguno, toda vez que el derecho supone indefectiblemente la necesidad deóntica del cumplimiento de su objeto, y si esta necesidad no existe, tampoco existirá estrictamente ese derecho. Puede suceder (esto es notorio) que la puesta en la

38 Thompson, J. J., "A Defense of Abortion", en AA.VV., The Rights and Wrongs of Abortion, Princeton \& London, Princeton U. P., 1974, pp. 11 y ss. Sobre este artículo, vid. la enérgica réplica de Finnis, J., "The Rights and Wrongs of Abortion", Philosophy \& Public Affairs, Princeton, núm. 2, 1973.

39 Warren, M. A., "El aborto", en AA.VV., Compendio de ética, dir. Peter Singer, Madrid, Alianza, 1995, pp. 417-431.

40 Farrell, M. D., La ética del aborto y de la eutanasia, Buenos Aires, Abeledo-Perrot, 1985, pp. 61 y passim. Pero no sólo los "liberals" consideran al derecho a la inviolabilidad de la vida del no nacido como relegable, sino también algunos "communitarians"; vid. v. gr. Bellah, R. et alii, The Good Society, New York, Vintage Books, 1992, pp. 124-130.

41 Vid. el libro ya clásico de Dworkin, R., Taking Rights Seriously, Harvard U.P., CambridgeMassachussetts, 1982. 
existencia de un derecho esté sujeta a condiciones: $v . g r$. el derecho a la educación supone una capacidad mínima de aprendizaje en el educando. Pero una vez que las condiciones necesarias para su existencia se han cumplido, el derecho se tiene absolutamente en cuanto tal derecho, es decir, como exigencia inexcusable e inexcepcionable, que se distingue claramente de las meras súplicas, ruegos o pretensiones, las que se dirigen más bien a la simple liberalidad o benevolencia de sus destinatarios. ${ }^{42}$

Del mismo modo, el derecho a la inviolabilidad de la vida se tiene o no se tiene: si el sujeto es un ser humano-persona, y no se dan ninguna de las causales eximentes de responsabilidad, $v$. $g r$. la agresión injusta del sujeto y la consiguiente legítima defensa del agredido, ese sujeto tiene el título completo que funda la existencia de su derecho a la inviolabilidad de la vida. Dicho de otro modo, el derecho a la inviolabilidad de la vida no admite grados, no puede tenerse un poco, o más o menos, o mucho, y por lo tanto no puede nunca ser dejado de lado o sobrepasado por consideraciones de utilidad o conveniencia, por importantes que estas aparezcan. De lo contrario, no estaríamos en presencia propiamente de derechos, sino de meros "edictos de tolerancia revocables", ${ }^{43}$ con lo que quedarían sin sentido todas las declaraciones de derechos y los hombres sujetos a la posibilidad, moralmente aceptable, de ser eliminados no bien su desaparición se presente como útil o conveniente.

\section{EL DERECHO A LA INVIOLABILIDAD DE LA VIDA EN LA SISTEMÁTICA}

\section{DE LOS DERECHOS HUMANOS}

Nos queda por analizar, aunque sea esquemáticamente, la tercera de las cuestiones que nos planteáramos respecto al derecho a la inviolabilidad de la vida, que es la de su ubicación en el contexto sistemático de los derechos humanos. A ese fin, es preciso agregar a lo afirmado en el parágrafo precedente, que los llamados derechos humanos no sólo son absolutos por las mismas razones por las que lo son todos los derechos, sino que, además, lo son por una razón todavía más radical: porque se trata de exigencias basadas en principios morales absolutos, es decir, inexcepcionables, que valen siempre y para siempre; ${ }^{44}$ "los absolutos morales ahora

42 Vid. Massini Correas, C. I., Filosofía del derecho, cit., pp. 77 y ss.

43 Spaemann, R., Lo natural..., cit., p. 90.

44 La biliografía sobre los absolutos morales es sumamente amplia, por lo que mencionaremos sólo algunos trabajos que nos parecen fundamentales: Grisez, G. \& Shaw, R., Beyond the New Morality. The Responsibilities of Freedom, Notre Dame-Indiana, Notre Dame U. P., 1988; Pinkaers, S., Ce 
Este obra forma parte del acervo de la Biblioteca Jurídica Virtual del Instituto de Investigaciones Jurídicas de la UNAM www.juridicas.unam.mx

https://biblio.juridicas.unam.mx/bjv

en discusión — ha escrito John Finnis- identifican acciones incorrectas, no acciones correctas; son normas negativas que resultan válidas siempre y en toda ocasión". ${ }^{45}$ Estos principios morales absolutos son aquellos cuya violación o infracción impiden de modo decisivo la realización de un bien humano básico o principal, tales como la vida, el conocimiento o la amistad; y es casualmente por el carácter decisivo del impedimento y por la principalidad del bien desconocido o atacado, por lo que son principios-normas que valen sin excepción, es decir, de un modo absoluto. ${ }^{46}$

Esta fundamentación en principios éticos absolutos es propia de todos y cada uno de los derechos humanos; en efecto, todos ellos se ordenan a salvaguardar un bien humano básico, y su violación impide siempre de modo decisivo la realización de ese bien; así, por ejemplo, la mentira de un testigo ante un tribunal impide de modo crucial el acceso al bien básico del conocimiento de la verdad, y la difamación obstaculiza gravemente la realización del bien principal de la amistad. Respecto de estos bienes - y de los correspondientes derechos - ha escrito Finnis que

en primer lugar, cada uno es del mismo modo una forma autoevidente del bien. En segundo lugar, ninguno puede ser reducido analíticamente a un mero aspecto de alguno de los otros, o a un mero instrumento para la prosecución de alguno de ellos. En tercer lugar, cada uno, cuando concentramos la atención en él, aparece razonablemente como el más importante. Por ello, no existe entre ellos una jerarquía objetiva [...]. Cada uno es fundamental; ninguno es más fundamental que cualquiera de los otros, porque cada uno puede ser centralizado y, en ese caso, reclama la prioridad de valor. De aquí que no exista prioridad objetiva de valor entre ellos. ${ }^{47}$

Ahora bien, ¿es correcto que no pueda establecerse jerarquía alguna de valor entre estos bienes y, por lo tanto, entre los correspondientes derechos? Varios autores han objetado esta posición de Finnis, entre los que cabe mencionar a Russell Hittinger y Garth Hallett, ${ }^{48}$ pero es nuestra opinión que nin-

qu'on ne peut jamais faire, Éditions Universitaires de Fribourg. Fribourg (Suisse), 1986; Composta, D., La nuova morale e i suoi problemi, Cittá del Vaticano, Libreria Editrice Vaticana, 1990.

45 Finnis, J., Absolutos morales, Barcelona, EIUNSA, 1992, p. 33.

46 Vid. Massini Correas, C. I., "La normatividad de la naturaleza y los absolutos morales", $\mathrm{Sa}$ pientia, Buenos Aires, núms. 195-196, 1995, pp. 99-105.

47 Finnis, J., Natural Law..., cit., pp. 92-93. Esta afirmación ha sido cuestionada por numerosos autores; entre los argentinos, vid. Soaje Ramos, G., "Nota crítica a NLNR", Ethos, Buenos Aires, núms. 10/11, 1983, p. 369.

48 Vid. Hittinger, R., "The Recovery of Natural Law and the Common Morality”, This World, núm. 
guno de ellos ha dado en el blanco con sus críticas. En rigor, es cierto que no pueden establecerse a priori jerarquías objetivas entre los bienes y derechos humanos, pero con una importante excepción: el derecho a la inviolabilidad de la vida. Es decir, puede sostenerse la imposiblidad de establecer un orden de prelación entre los derechos, pero siempre que se excluya de esta afirmación al derecho a la inviolabilidad de la vida, el que se encuentra en un rango superior al del resto de los derechos. Pero, ¿cuáles son los fundamentos de esta excepción? Estos pueden reducirse fundamentalmente a dos: uno de carácter teórico y otro de naturaleza práctica.

El de carácter teórico o especulativo puede resumirse del siguiente modo: los bienes básicos que son el fundamento de los derechos humanos, excepción hecha del derecho a la inviolabilidad de la vida, se refieren a perfecciones humanas que revisten un carácter existencialmente no autónomo, ${ }^{49}$ es decir, si utilizamos la terminología tradicional, solamente accidentales. En efecto, dichas perfecciones: el conocimiento, la experiencia estética, la amistad, etcétera, no tienen su existencia en sí sino en un sujeto de inhesión, de carácter existencialmente autónomo, al que cualifican y perfeccionan. Estos accidentes suponen necesariamente para su existencia, la de un sujeto sustancial, según la terminología tradicional, que alcanza su perfección por medio de esas determinaciones accidentales y que las sostiene en la existencia.

Por el contrario, el valor básico de la vida hace referencia directa al modo de existir propio de los entes humanos, que es existencialmente autónomo o sustancial. La persona es "sustancia individuada de naturaleza racional", ${ }^{50}$ establece la clásica definición de Boecio, poniendo en evidencia el carácter de sustancia que le compete ante todo al ser del hombre. El hombre es, por lo tanto, y en primer lugar, "sustancia viviente", es decir, un ente existencialmente autónomo que existe como ser vivo, en cuanto participa de la perfección radical de la vida. Y es bien claro que, desde una perspectiva filosófica, la perfección radical y raigal de la sustancia es ontológicamente superior a cualesquiera de sus determinaciones accidentales, ya que existe en sí autónomamente, sin depender existencialmente de otra realidad.

18, 1987, p. 69, y Hallett, G., “The 'Inconmensurability' of Values”, The Heythrop Journal, núm. 28, 1987, pp. 376-381. Para la crítica de estas posiciones, vid. Gahl, R., op. cit., pp. 146-150.

49 Vid. Kalinowski, G., L'impossible métaphysique, Paris, Beauchesne, 1981, pp. 145 y ss.

50 Vid. sobre la inteligencia de esta definición: Trigeaud, J. M., Personne ou la justice au double visage, Genova, Studio Editoriale di Cultura, 1990, pp. 49 y ss. 
Este obra forma parte del acervo de la Biblioteca Jurídica Virtual del Instituto de Investigaciones Jurídicas de la UNAM www.juridicas.unam.mx

Por ello, desde un punto de vista estrictamente especulativo, la vida aparece como una perfección más básica que aquella que compete a las restantes perfecciones humanas accidentales. Pero a esto podría objetarse que, en una consideración estrictamente práctica, lo que interesa es la línea de las perfecciones accidentales del sujeto y no la de sus constitutivos existenciales.

El hombre — escribe Casaubon, parafraseando a Tomás de Aquino- como todos los entes vivientes total o parcialmente corpóreos, nace con un ser sustancial, pero imperfecto, por lo cual su bien (ontológico) simplemente tal, o sea su perfección ontológica, se halla al término de una evolución que, ontológicamente hablando, es un accidente, un ente accidental. De manera que, aunque ente y bien ontológico sean convertibles, en los entes mencionados el ser sustancial es sólo un bien relativamente tal, mientras que gracias a cierto ser accidental adquirido, llegan a su bien simplemente tal. ${ }^{51}$

Con esto pareciera que la perfección primera o sustancial del ente fuera, en línea de consideración práctica, menos valiosa que las perfecciones adventicias, en la posesión de las cuales consiste propiamente la perfección, completud o "florecimiento" del ente.

Pero no obstante lo afirmado, es preciso recordar que, como lo ha sostenido De Raeymaker, "la bondad sustancial es la fuente de las operaciones accidentales por las cuales el ente particular llega a desarrollarse implicando a las demás realidades en su evolución. Cuanto más perfecto es el ente sustancial, más vasto es su campo de actividad". ${ }^{52}$ Dicho de otro modo, la amplitud y la posibilidad de desarrollo de las perfecciones humanas depende raigalmente del modo de la existencia sustancial del hombre, es decir, de la vida humana. Sin vida humana no hay posibilidad de conocimiento, de amistad, de experiencia estética, de vida religiosa, y así sucesivamente. Por ello, si bien la perfección que provee al sujeto es menos desarrollada, es no obstante más básica, sobre todo si tomamos la expresión "básica" en el sentido de fundamento radical o de raíz constitutiva.

Pero además, y si nos colocamos en una línea estrictamente práctica de consideración, resulta evidente que la vida tiene un carácter especial en cuanto bien humano básico, ya que reviste una definitividad y una decisividad que no corresponde a los restantes bienes. Efectivamente, un

51 Casaubon, J. A., "Estudio crítico sobre lógica del ser y lógica del deber ser en la teoría egológica”, Ethos, Buenos Aires, núms. 2-3, 1975, p. 51. Vid. Massini Correas, C. I., El derecho, los derechos humanos y el valor del derecho, Buenos Aires, Abeledo-Perrot, 1987, pp. 199-222.

52 Raeymaker, L., Filosofía del ser, Madrid, Gredos, 1968, p. 244. 
Este obra forma parte del acervo de la Biblioteca Jurídica Virtual del Instituto de Investigaciones Jurídicas de la UNAM www.juridicas.unam.mx

https://biblio.juridicas.unam.mx/bjv

atentado $v$. gr., contra el bien básico del conocimiento, implica una falta moral grave y la violación de un derecho humano, pero, en la gran mayoría de los casos, ese atentado no impide de modo definitivo todo conocimiento humano: permanecen los conocimientos anteriores y podrán adquirirse ulteriomente otros. En cambio, en el caso de los atentados a la inviolabilidad de la vida, cada atentado —que resulte "exitoso", se entiende - cercena de modo decisivo y definitivo todas las posiblidades humanas de perfeccionamiento. Puede decirse que el atentado a la vida lo es, al mismo tiempo, contra todo el resto de los bienes humanos básicos, ya que su ausencia impide la posibilidad misma de su concreción. Por lo tanto, si el criterio para determinar el carácter básico de los bienes radica en la realización humana, es claro que la condición primera y más básica para esa realización es la permanencia en la vida —o la intangibilidad de la vida - del sujeto de esa realización. De este modo, es posible hablar de la vida como de un bien más básico que el resto, como el bien central a cuyo alrededor se organizan los restantes bienes humanos básicos.

Como consecuencia, corresponde considerar al derecho humano a la inviolabilidad de la vida como más fundamental que el resto, ${ }^{53}$ ya que su violación supone necesariamente la violación indirecta de todos los derechos humanos. "Para ser titular de un derecho - escribe Herrera Jaramillo- primero hay que ser, por eso el más fundamental de los derechos es el derecho a la vida, manifestación de la autoposesión que la persona tiene sobre sí. Si no se tiene el derecho a ser, no hay posibilidad de tener ningún derecho". ${ }^{54}$ Por lo tanto, y parafraseando a Hannah Arendt,,55 es posible sostener que la categoría central de lo ético-jurídico es la categoría de la vida, o de la "vitalidad"; esto se evidencia, entre otras razones, por el hecho de que la primera de las inclinaciones naturales es la que se ordena a la supervivencia, tal como lo sostiene Tomás de Aquino cuando estudia el orden de los preceptos de la ley natural. ${ }^{56}$

\section{EL MENOSPRECIO DE LA VIDA}

53 Vid. Massini Correas, C. I., "Los derechos humanos y la Constitución reformada”, en J. Sarmiento García (ed.), La reforma constitucional interpretada, Buenos Aires, Depalma, 1995, pp. 86 y ss.

54 Herrera Jaramillo, F. J., El derecho a la vida y el aborto, Pamplona, EUNSA, 1984, p. 133.

55 Arendt, H., The Human Condition, New York, The U. of Chicago Press, 1958. Allí Arendt sostiene que la categoría más importante del pensamiento político es la de la natalidad, así como que el hombre no es un "ser para la muerte", sino antes bien un "ser para la vida".

56 Vid. Aquino, Tomás de, Summa Theologiae, I-II, q. 94, a. 2. Sobre el derecho a la inviolabilidad de la vida en Tomás que Aquino, vid. Kalinowski, G., "Le droit à la vie chez Thomas d'Aquin", en Archives de Philosophie du Droit, París, 1985, t. 30, pp. 316-330. 
Este obra forma parte del acervo de la Biblioteca Jurídica Virtual del Instituto de Investigaciones Jurídicas de la UNAM www.juridicas.unam.mx https://biblio.juridicas.unam.mx/bjv

Luego de todo lo expuesto acerca de la centralidad de la vida como bien humano básico y del carácter fundamentalísimo del derecho a su inviolabilidad en la sistemática de los derechos humanos, se hace necesario dar una respuesta, aunque sea somera, a una cuestión dramáticamente vigente en la vida social contemporánea: la cuestión que plantea el cada vez más difundido menosprecio de la vida humana, tanto en las ideas como en las praxis concretas de los hombres de nuestro tiempo. Los síntomas de este fenómeno son múltiples y abarcan una gran cantidad de dimensiones de la vida humana: en el ámbito jurídico, la despenalización progresiva del aborto; en el del pensamiento ecológico, un antihumanismo que propone la supresión masiva de vidas humanas para mejor preservar el entorno natural; en el de las políticas sociales, un antinatalismo militante y agresivo; en el del pensamiento moral, una progresiva pérdida de absolutidad del derecho a la inviolabilidad de la vida, transformado - ya lo vimos- en derecho prima facie o relativo; también en el campo ético-jurídico, la despenalización, y la consiguiente autorización jurídica, de la eutanasia; también en el campo ético, la difusión a nivel mundial, de las diversas formas de manipulación genética y, más radicalmente, en el pensamiento filosófico, un antihumanismo cada vez más extendido que llega hasta la negación, explícita o implícita, del sujeto humano y, consecuentemente, de los derechos humanos, ${ }^{57}$ entre ellos, especialmente, del derecho a la inviolabilidad de la vida.

Frente a este inquietante conjunto de fenómenos, es necesario preguntarse, en sede filosófica, por sus causas fundamentales o más relevantes, para que sea posible luego, efectuar un dignóstico preciso de nuesta situación contemporánea y de las perspectivas posibles de su futuro. La cuestión no es sencilla, toda vez que se han intentado diversas explicaciones de este fenómeno, la más difundida de las cuales coloca los orígenes del antihumanismo actual en la crisis del pensamiento de la modernidad, centrado sobre el sujeto humano y sus creaciones. ${ }^{58}$ Por nuestra parte, va-

57 Vid. Renaut, A. y Sosoe, L., Philosophie du droit, Paris, PUF, 1991, pp. 43 y ss., donde se analiza y critica el pensamiento de Michel Foucault y sus discípulos sobre el tema que nos interesa. Merece ser transcrito aquí un texto de Foucault que pone en evidencia a donde conduce la negación del sujeto humano y de sus derechos: "cuando el proletariado tome el poder — escribe Foucaultpuede ser bastante posible que ejerza contra las clases sobre las que ha triunfado, un poder violento, dictatorial e incluso sangriento: no veo qué objeción pueda hacérsele a esto", Comsky, N. y Foucault, M., La naturaleza humana: ¿justicia o poder?, Valencia, U. de Valencia, 1976, pp. 55-56.

58 La biliografía sobre la crisis de la modernidad es de una amplitud que resulta exasperante; 
Este obra forma parte del acervo de la Biblioteca Jurídica Virtual del Instituto de Investigaciones Jurídicas de la UNAM www.juridicas.unam.mx

https://biblio.juridicas.unam.mx/bjv

mos a ensayar brevemente un esquema de interpretación de este proceso de desdignificación de la persona humana, que ha conducido a considerarla como un mero centro de imputación normativa, un núcleo de atribución de cierto tipo de predicaciones, una creación de estructuras objetivas de discurso, un simple conjunto de fenómenos empíricos ocasionalmente vinculados, un "ser genérico" integralmente determinado por la evolución de las estructuras económicas, o bien una mera creación de la historia sin sustrato esencial alguno. ${ }^{59}$

Sin proponer aquí, por evidentes razones de espacio, una explicación del origen histórico de este fenómeno, vamos a adherir la siguiente hipótesis interpretativa, defendida por muy notables pensadores de nuestro tiempo: la razón fundamental del proceso de desdignificación, desvalorización o, en frase de Lewis, "abolición” del hombre, radica en la ruptura, cada vez más radical, de cualquier referencia a un Ser absoluto y trascendente, fuente raigal, por vía de participación, de la dignidad que compete a todo ser humano. En este sentido, Robert Spaemann ha escrito que

la idea de la dignidad humana encuentra su fundamentación teórica y su inviolabilidad en una ontología metafísica, es decir, en una filosofía de lo absoluto [...]. La presencia de la idea de lo absoluto en una sociedad es una condición necesaria — aunque no suficiente — para que sea reconocida la incondicionalidad de la dignidad de esa representación de lo absoluto que es el hombre. ${ }^{60}$

En otros lugares hemos mostrado con cierta extensión cómo el inmanentismo ético-jurídico, con su necesaria negación de todo absoluto noética u ontológicamente trascendente, supone inexorablemente la negación de todo derecho humano inexcepcionable, ya que un derecho de esa naturaleza, es decir, absoluto e inexcusable, supone necesariamente un fundamento también absoluto, es decir, sin límite ni restricción. Pero como el hombre no es el absoluto - todos tenemos esa experiencia- ni tampoco aparece ese absoluto en el "mundo sublunar", como gustaba llamarlo a Aristóteles, es evidente que un fundamento de esa índole ha de ser busca-

lectuales, Romano Guardini había escrito un libro notable sobre el tema: El fin de los tiempos modernos, Buenos Aires, Sur, 1973 (la primera edición alemana de este texto es de 1949); por otra parte, lo mejor que hemos leído sobre este tópico es el libro de Innerarity, D., Dialéctica de la modernidad, Madrid, Rialp, 1990.

59 Sobre todas estas teorías, vid., Massini Correas, C. I., Filosofía del derecho, cit., pp. 91 y ss.

60 Spaemann, R., Lo natural..., cit., pp. 122-123. 
Este obra forma parte del acervo de la Biblioteca Jurídica Virtual del Instituto de Investigaciones Jurídicas de la UNAM www.juridicas.unam.mx

do más allá, transcendens el universo; más allá de la contingencia y relatividad del mundo material y humano. ${ }^{61}$

Otro tanto ocurre con la dignidad del hombre, fundamento formal de los derechos humanos y, en primer lugar, del derecho a la inviolabilidad de la vida. Esa dignidad o preeminencia por sobre el resto del universo le viene dada al hombre por su especial y eminente modo de participación en el Ser absoluto; él es, como sostiene Battista Mondin, un "absoluto participado", 62 el más perfecto de los entes que no son el Ser, sino que lo tienen participado en un modo de ser o esencia que los acota y limita, pero que les marca al mismo tiempo las líneas fundamentales de su perfeccionamiento. La dignidad de la persona humana no es, por lo tanto, sino un modo egregio de participación en la eminente dignidad de la Persona Absoluta; cualquier otra pretensión de fundamentar la dignidad del hombre ha de girar en el vacío y no alcanzará a justificar propiamente nada. En efecto, una dignidad que el hombre, o un conjunto de hombres, se dieran a sí mismos, no merecería el respeto incondicionado de otros hombres que decidieran quitársela, no podría garantizar un reconocimiento universal y menos aún constreñir a los otros a respetarla absolutamente. ${ }^{63}$

Ha escrito a este respecto Leszek Kolakowski, que

Hegel decía que el hombre sólo puede respetarse a sí mismo si tiene conciencia de un ser superior, mientras que la promoción del hombre por él mismo a la posición más elevada entraña una falta de respeto de sí [...]. La ausencia de Dios - concluye Kolakowski-cuando se sostiene consecuentemente y se analiza por completo, significa la ruina del hombre, en el sentido de que demuele, o priva de significado, todo lo que nos hemos habituado a considerar como la esencia del hombre: la búsqueda de la verdad, la distinción entre el bien y el mal, la exigencia de dignidad [...]. ${ }^{64}$

Y demuele también — agregamos nosotros - el derecho a la inviolabilidad de la vida, ya que la existencia de un ente desprovisto de una dignidad garantizada por un Ser que trascienda todo cuestionamiento humano, no puede plantear una exigencia de respeto e inviolabilidad que genere un deber absoluto en los demás sujetos. Mal que les pese a mu-

61 Vid., entre otros trabajos, Massini-Correas, C. I., "Diritti umani 'deboli' e diritti umani 'assoluti'”, Quaderni di Iustitia, núm. 40, Roma, 1991, pp. 137-157.

62 Vid. Mondin, B., Il valore uomo, Roma, Dino Ed., 1983, p. 181.

63 Vid. Fabro, C., Drama del hombre y misterio de Dios, Madrid, Rialp, 1977, pp. 747-748.

64 Kolakowski, L., Si Dios no existe..., Madrid, Tecnos, 1985, p. 214. 
chos de nuestros contemporáneos, Dios es el único garante seguro de los derechos humanos y de la dignidad que los fundamenta, por lo que $\mathrm{Su}$ oscurecimiento en el horizonte humano no puede sino conducir al menosprecio del hombre y a la fragilidad de sus derechos. El derecho a la inviolabilidad de la vida es papel mojado cuando la disposición de la existencia humana ha sido quitada a Dios y puesta en las peligrosas manos de la tecnociencia, la opinión pública o los detentadores del poder.

Por otra parte, es preciso recalcar que esta potestad asumida por ciertos hombres de decidir acerca de quiénes han de continuar con vida y quiénes no, significa lisa y llanamente la abolición de los principios sobre los que se levanta el Estado democrático contemporáneo; efectivamente, los dos principios centrales sobre los que gira la democracia en su versión actual son: i) la participación de todos los ciudadanos en el ejercicio del gobierno y ii) la vigencia de los derechos humanos. ${ }^{65}$ Ambos principios resultan anulados no bien se acepta el criterio de que no todos los seres humanos tienen el derecho a la vida, sino sólo algunos de entre ellos, ya que entonces no todos tienen el derecho a participar de las decisiones públicas, y los derechos humanos dejan de ser "humanos", es decir, correspondientes a todo ente humano, para pasar a ser privilegios de los adultos sanos y mejor dotados.

En este sentido, ha escrito el filósofo belga Michel Schooyans, que

a partir del momento en que el Estado (o ciertas corporaciones; CIMC) se reservan el derecho de decidir, por medio de sus órganos institucionales, cuál ente humano tiene el derecho a la protección y al respeto y cuál otro no tiene ese derecho, ese Estado cesa de ser democrático, ya que niega la razón fundamental por la que ha sido instaurado: la defensa del derecho de todo ente humano a la vida. Y el poder del Estado se transforma en arbitrario, desde que autoriza a ciertos ciudadanos a ejecutar impunemente a sus semejantes, sin haber ofrecido o permitido a las víctimas la posibilidad de ser escuchados. ${ }^{66}$

Por lo tanto, proclamarse ferviente democrático y proponer al mismo tiempo la exclusión de un sector de entes humanos de la titularidad del derecho a la inviolabilidad de la vida, resulta evidentemente autocontradictorio, ya que ambas afirmaciones no pueden ser sostenidas al mismo

65 Vid. Tocqueville, A. de, Inéditos sobre la Revolución, Madrid, Ed. Dalmacio Negro, Dossat, 1980, pp. 185-186.

66 Schooyans, M., Maîtrisse de la vie, domination de hommes, Namur-París, 1986, p. 19. 
Este obra forma parte del acervo de la Biblioteca Jurídica Virtual del Instituto de Investigaciones Jurídicas de la UNAM www.juridicas.unam.mx

tiempo, al menos mientras tengan vigencia en este mundo las leyes de la lógica.

\section{CONCLUSIONES}

Luego de los desarrollos efectuados, vamos a ser especialmente breves a la hora de extraer las correspondientes conclusiones; ellas pueden resumirse en los siguientes puntos:

A) El derecho a la vida, designado más precisamente como derecho a la inviolabilidad de la vida, tiene su fundamento en el bien humano básico de la existencia viviente, que es la condición necesaria, aunque no suficiente, para la realización del resto de los bienes humanos y, por consiguiente, de la completa perfección humana;

B) Este derecho corresponde a todo ente que pertenece a la especie homo sapiens y durante toda la duración natural de su vida, es decir, desde la concepción hasta la muerte natural; por lo tanto, la distinción entre ser —o ente- humano y persona, carece de justificación racional y supone un radical desconocimiento del carácter óntico — no meramente fenoménico- de la personeidad del hombre;

C) El derecho a la inviolabilidad de la vida es un derecho absoluto, en el sentido de que es inexcepcionable y vale para todos los hombres, desde siempre y para siempre; la noción del derecho a la inviolabilidad de la vida como mero derecho prima facie no sólo es irrazonable, sino que convierte a ese derecho en un "edicto de tolerancia revocable" a voluntad por quien detente ocasionalmente el poder social;

D) Ese derecho tiene un papel central en la sistemática de los derechos humanos, ya que tiene por contenido un bien humano más básico que todo el resto, pues resulta ser la condición necesaria, primera y más fundamental, para la realización de los otros bienes; por otra parte, tiene como objeto a la misma existencia sustancial del hombre, que es el sustrato en el que inhieren las restantes perfecciones humanas, existencialmente no autónomas;

E) Todas las afirmaciones precedentes se oponen frontalmente al decidido antihumanismo, con el consiguiente menosprecio de la vida humana, que caracteriza a una buena parte del pensamiento actual. Este antihumanismo no es sino una necesaria consecuencia del inmanentismo y antitrascendentismo del pensamiento tardomoderno y posmoderno, que niegan la posibilidad de acceder al conocimiento de la realidad en sí y, 
por lo tanto, al absoluto que la fundamenta. "La filosofía - ha escrito André Frossard - ha roto con la realidad para no oírla hablar de Dios" ${ }^{67}$ Pero este antihumanismo tiene como consecuencia necesaria, y así debe ser asumido por quienes lo propugnan, la difuminación de los derechos humanos, la negación de la democracia política y, en definitiva, la "abolición del hombre”, prevista hace ya más de cincuenta años por Jack Lewis. ${ }^{68}$

F) Finalmente, cabe responder a una pregunta que surgirá inevitablemente entre los oyentes: ¿qué tiene que ver todo esto con la encíclica Evangelium Vitae? En realidad, se trata sólo de un ensayo de fundar racionalmente y de explicitar lo que el Pontífice ha querido significar cuando defiende en esa Carta la existencia "de algunos derechos fundamentales, que pertenecen originariamente a la persona y que toda ley positiva debe reconocer y garantizar. Entre ellos — concluye Juan Pablo II- el primero y fundamental es el derecho inviolable de cada ser humano inocente a la vida". ${ }^{69} \mathrm{Y}$ este ensayo no es sino un intento de cumplir con la tarea que el papa encomienda a los intelectuales, cuando les encarga "poner de relieve las razones antropológicas que fundamentan y sostienen el respeto de cada vida humana". ${ }^{70}$ Esperamos haber cumplido aceptablemente con nuestra parte en esa tarea.

67 Frossard, A., Il y a un autre monde, París, Fayard, 1973, p. 116.

68 Lewis, C. S., The Abolition of Man, London, Harper-Collins, 1978.

69 Evangelium Vitae, III, 71.

70 Evangelium Vitae, IV, 82. 


\section{LOS DERECHOS HUMANOS ENTRE EL TÓPICO Y LA UTOPÍA}

Andrés OLLERO TASSARA

SUMARIO: I. Tópicos al servicio de la utopía clandestina. II. A la búsqueda de un fundamento: entre escepticismo y razón problemática. III. La "inventio" tópica como invitación a recuperar la utopía. IV. Debate antropológico tras el presunto consenso sobre los derechos humanos. V. Cómo poner a salvo de los tópicos a la utopía.

Tanto el cuadragésimo aniversario de la Declaración Universal de Derechos Humanos de las Naciones Unidas, que - cumplido el pasado mes de diciembre - ha motivado estas Jornadas, como el segundo centenario de la Revolución francesa - celebrado en el cercano mes de julio - animan a un balance sobre el alcance histórico de la lucha por un reconocimiento político y una garantía jurídica de las exigencias fundamentales de lo humano.

La lucha por los derechos humanos aparece históricamente con caracteres de utopía social. Mueve el afán por lograr objetivos que desbordan el marco consolidado por los tópicos socialmente vigentes. Es un duro esfuerzo protagonizado por minorías, tan convencidas de su verdad como para aspirar a conquistar la aceptación de la mayoría, insensible hasta ese momento respecto a dichas exigencias. El balance es, sin duda, positivo. No ha dejado de constatarlo — dentro de un diagnóstico de la sociedad actual no exento de sombras - quien hoy es universalmente reconocido como la voz más autorizada en defensa de lo humano: entre los "aspectos positivos" de nuestro momento histórico, "el primero es la plena conciencia, en muchísimos hombres y mujeres, de su propia dignidad y de la de cada ser humano", expresada "en una viva preocupación por el respeto de los derechos humanos y el más decidido rechazo de sus violaciones". ${ }^{1}$

Esta conversión en tópico social indiscutido de no pocas de las exigencias de tan trabajosa utopía es, sin duda, el mejor homenaje histórico

1 Juan Pablo II, Sollicitudo rei socialis (30.XII.1987), 26. 
Este obra forma parte del acervo de la Biblioteca Jurídica Virtual del Instituto de Investigaciones Jurídicas de la UNAM www.juridicas.unam.mx

https://biblio.juridicas.unam.mx/bjv

a sus convencidos impulsores. Se aceptan como verdades éticas exigencias no hace mucho consideradas irrealizables, inoportunas, inconcebibles o simplemente ridículas. Pero la conversión de la utopía en tópico no deja de llevar consigo riesgos, dada la ambivalencia de lo que, por indiscutible, llega a darse por supuesto. ${ }^{2}$ Los tópicos tienden a convertirse en punto final de una utopía autosatisfecha, erigiéndose así en nido de gérmenes de su posible degeneración. Lo que era conciencia consolidada por su generalización suele acabar jugando como factor de insensibilización acrítica; el resultado de la utopía progresista puede actuar luego, hecho tópico, como blindaje reaccionario que impide mantenerla abierta.

La utopía degenerada en tópico se cierra al alumbramiento de nuevas "generaciones" 3 de derechos, que hagan aparecer como dignas de reconocimiento y garantía exigencias incumplidas de lo humano. A la vez, frena la efectiva generalización de sus aspectos más primarios y elementales. Ni siquiera derecho tan básico como el de la vida queda a salvo; porque los tópicos insensibilizan cuando, de modo ostensible, se lo niega a los presuntos portadores de vidas indeseadas, indeseables o meramente improductivas; ya se trate del inocente no nacido, del culpable de delitos que piden venganza o del enfermo terminal cuya situación se estima ( $\sin$ contar necesariamente con él) insoportable. No digamos nada si lo que se plantea es el derecho al trabajo. Su carencia se pretende suplir subisidiadamente con fórmulas que, aunque se disfrazan pomposamente de "Estado de bienestar", consolidan a veces un lamentable "Estado de beneficencia", incompatible con el ejercicio de libertades políticas elementales, dado el obligado clientelismo que deriva de este "generoso" desborde de tan paternal Estado.

La ambivalencia del tópico cobra aún más relevancia cuando, en vez de ser considerado como constatación histórica de una utopía con fundamento, reclama para sí el papel de fundamento de la utopía. ${ }^{4}$ Tal ocurre

2 Un expresivo cuadro del juego de estos tópicos en C. I. Massini, "Los derechos humanos en debate", Los derechos humanos, Mendoza, 1985, pp. 112 y ss. ¿Nos obliga esta evidente implementación ideológica a certificar su falta de realidad? M. Villey dedicó un agudo tratamiento histórico a intentar convencer de ello: Le droit et les droits de l'homme, París, 1983.

3 Entre las múltiples referencias a esta tipología histórica, recientemente, I. Ara, "Los derechos humanos de la tercera generación en la dinámica de la legitimidad democrática", en J. Muguerza y otros, El fundamento de los derechos humanos, edición preparada por G. Peces-Barba, Madrid 1989 , pp. 57 y ss.

4 A la imposible tarea de fundamentar sobre los tópicos vigentes una utopía hemos aludido en nuestro trabajo "Cómo tomarse los derechos humanos con filosofía", incluido ahora en Derechos 
Este obra forma parte del acervo de la Biblioteca Jurídica Virtual del Instituto de Investigaciones Jurídicas de la UNAM www.juridicas.unam.mx

https://biblio.juridicas.unam.mx/bjv

porque el horror a lo metafísico lleva a buscar en un supuesto consenso actual su fundamentación imprescindible para no condenarse al absurdo juego de postular unos derechos fundamentales sin fundamento. Pretender basar en un presente estabilizado las urgencias del futuro es como empeñarse en saltar sobre la propia sombra. Coherentemente, se estaría proclamando con plena autosatisfacción el fin de la historia, una vez consumada la utopía. Con frecuencia no ocurre así, sino que se sigue invitando a un "progreso" que, paradójicamente, tendría su asiento en lo ya consumado. En estos casos la propuesta utópica no se cierra, pero sí el debate sobre sus perfiles y la exhibición razonada de su fundamento. El tópico acaba sirviendo a la utopía, además de como aparente fundamento, como blindaje acrítico. El tópico — presuntamente expresivo de un consenso histórico- acaba encubriendo inconfesadas distinciones entre una historia "verdadera" (portadora de gérmenes de progreso) y otra "falsa" (descalificada por sus desviaciones ilegítimas o reaccionarias); sin explicitar quién, y por qué, es el competente para realizar tan decisivo discernimiento, o negando sin más — tácitamente — tal competencia al discrepante por el mero hecho de serlo.

Cumplido por el tópico su positivo papel de constatación histórica, se hace indispensable neutralizar reflexivamente una doble implementación: la que cercena una lucha sin posible final y la que pretende continuarla sin abrirla a una argumentación capaz de generar un real consenso, autoadjudicándose la interpretación del progreso en línea con el más rancio despotismo ilustrado. Parece obligado, pues, detectar qué tópicos socialmente vigentes pueden estar cumpliendo esta negativa función, presentando como indiscutibles determinadas versiones de lo humano o descalificando, sin juicio previo, alternativas frente a las que no parece disponerse de argumentación capaz de lograr consenso alguno.

\section{TÓPICOS AL SERVICIO DE UNA UTOPÍA CLANDESTINA}

El mantenimiento de la lucha por los derechos humanos como utopía abierta obliga a evitar los instrumentos de una doble cerrazón: la que pretende fundar en los tópicos una utopía estática — que acabaría cumplien- 
Este obra forma parte del acervo de la Biblioteca Jurídica Virtual del Instituto de Investigaciones Jurídicas de la UNAM www.juridicas.unam.mx

do una función "ideológica", defensora de cualquier statu quo- y la de los que postulan una utopía clandestina, inconfesada en la medida en que se la da por supuesta, hasta convertir en sospechoso a cualquiera que - contra corriente - se permita esbozar la mínima crítica sobre el acierto de sus perfiles. Al discrepante no se le trata como al portador de una utopía alternativa, con la que debatir argumentadamente, sino como a un reaccionario, enemigo de lo que presuntamente sería ya un logro indiscutido e indiscutible.

Entre los tópicos más eficaces para hacer avanzar clandestinamente una utopía cerrada a todo debate destacan en nuestro inmediato contorno algunos:

Notable éxito alcanza el tópico de "las exigencias de la realidad social", concepto indeterminado que ha llegado a encontrar asiento en nuestro Código Civil. Tal invocación puede recordar — juiciosamentela necesidad de ponderar con prudencia el alcance teleológico de la proyección de los criterios éticos del derecho, al incidir sobre circunstancias sociales cambiantes. Nada más digno de aplauso. El problema surge cuando su blindaje acrítico lleva al tópico a convertir las circunstancias sociales en criterio ético indiscutible. Se consuma así la peculiar falacia naturalista propia del "sociologismo", que acompañó a la sociología desde su misma génesis comtiana; aunque en favor de su fundador ha de reconocerse que su propuesta de la "física social" como moral fue todo menos clandestina. Como ocurría cuando se apelaba a la historia como fundamento de lo humano, nos encontramos en la práctica con un doble rasero. Una "realidad social", exigible por extendida, podría llevar a despenalizar, por ejemplo, el consumo público de drogas. Otra rechazable, sea cual sea su consistencia cuantitativa, autorizaría a poner en marcha una cruzada contra la notable evasión fiscal producida mediante el camuflaje de dinero "negro" en seguros de prima única. Quien invoca el citado tópico se guardará mucho de establecer tan enojoso discernimiento, porque si acude al tópico es, precisamente, para sustraer su propuesta a todo debate abierto.

No menos eficaz se muestra el tópico de "las exigencias del progreso científico". Se trata de un peculiar estrambote del "saber para poder" que acompañó al nacimiento de la ciencia moderna. La dimensión cualitativa de la ética se ve suplantada por la conversión de lo cuantitativo en criterio supremo. La ciencia nos haría progresar haciendo factible lo hasta ahora imposible. "Poder" hacer algo nuevo implicaría un progreso indis- 
Este obra forma parte del acervo de la Biblioteca Jurídica Virtual del Instituto de Investigaciones Jurídicas de la UNAM www.juridicas.unam.mx

https://biblio.juridicas.unam.mx/bjv

cutible; sólo el oscurantismo puede sugerir que renunciemos a una nueva posibilidad, en aras de un "deber" marcado por tabúes o prejuicios éticos. En el terreno teórico, esta mentalidad parece sintonizar con la propuesta de una "complejidad" social, entendida como multiplicación de alternativas "posibles", que sería irracional someter a criterios de "reducción" tan rígidos como los de la ética convencional; 5 el oportunismo calculado de la racionalidad sistémica se erige así en nueva muestra de un "sociologismo" que no cesa. En el orden práctico, bastaría evocar la ausencia de debate social que ha precedido a nuestra "progresista" ley sobre "fecundación asistida" para calibrar la incidencia del tópico citado.

Notoriamente socorrido resulta el recurso al consenso social como tópico capaz de obviar toda discrepancia. La misma sociología sistémica ha descrito con particular lucidez la inversión que se ha producido en el esquema de legitimación política, con la posible manufactura del consenso mediante técnicas de comunicación: de una presunta sociedad crítica y pensante, capaz de generar esa opinión pública que sirva de matriz de las propuestas normativas, a una sociedad programada para que piensen por ella —en aras de una óptima "reducción de complejidad" — adhiriéndose inconscientemente al consenso manufacturado. El tópico, sin embargo, puede incluso ahorrar tales fatigas. El mismo ministro que anuncia periódicamente una posible ampliación de los supuestos en que el aborto resultará despenalizado, si así lo exigen las “expectativas sociales", se declarará incapaz de suministrar al Parlamento los datos precisos para poder calibrar la incidencia social de su última reforma.

Especialmente rentables para una utopía clandestina se muestran los tópicos capaces de neutralizar prácticamente cualquier utopía alternativa. Ninguno tan eficaz como el que obliga a no imponer las propias convicciones a los demás. Se consagra así una peculiar teoría del derecho, que lo haría capaz de cumplir su función social sin imponer "convicción" alguna (o imponiendo sólo aquello que se pruebe incapaz de generarla). Oscilamos, pues, entre la propuesta anarquista de un derecho sin imposición (o sea, una sociedad sin derecho) y la receta arbitraria que sólo permitiría imponer lo no convincente. Paradojas aparte, nos hallamos ante un recurso eficaz para descalificar cualquier propuesta ética no encubierta, rechazándola como perturbadora de la asepsia de lo público, mientras los

5 Al respecto nuestro estudio "Systemtheorie: ¿filosofía del derecho o sociología jurídica?", ahora en Derechos humanos y metodología jurídica (nota 4), pp. 70 y 83; otras referencias en el mismo volumen, pp. 91 y ss. 
Este obra forma parte del acervo de la Biblioteca Jurídica Virtual del Instituto de Investigaciones Jurídicas de la UNAM www.juridicas.unam.mx

https://biblio.juridicas.unam.mx/bjv

184

ANDRÉS OLLERO TASSARA

contenidos éticos de la utopía clandestina se disfrazan de "neutrales" para mejor neutralizarla. La crítica de Dworkin al presunto "doble recuento" de los que pretenden intervenir en el debate democrático sin estar directamente afectados por un problema ${ }^{6}$ parece expresar teóricamente este tópico; a la vez deja al descubierto su trasfondo ético clandestino, gracias al cual se discierne quiénes son los realmente "afectados" por un problema, resuelto en su caso en clave individualista. La anunciada despenalización de la eutanasia puede hacer reverdecer, entre nosotros, este tópico.

En países como el nuestro, de honda raigambre clerical (en versión devota o laicista) ejerce gran eficacia descalificadora el tópico del pluralismo no confesional. El expeditivo magisterio del imán Jomeini convirtió al "fundamentalismo" en tópico descalificador de envidiable contundencia. Su fungibilidad lo hace tan aplicable a un comando suicida como a cualquiera que pretenda formular propuestas éticas con "fundamento" más sólido de lo permitido por los patriarcas del pensamiento "débil". La entusiasta caza de brujas contra el fundamentalismo llevó a un ministro español — superado tiempo ha su stalinismo - a propiciar una edición internacional, financiada con fondos públicos, de los no confesionales Versos satánicos; sin que el tópico le permitiera reflexionar mínimamente sobre la legitimidad de utilizar dinero de todos para lesionar las convicciones de algunos. Por dicha vía el laicismo se convierte en religión oficial (no por inconfesada menos confesional), capaz incluso de llamar desde el poder a cruzadas laicas como la aludida.

\section{A LA BÚSQUEDA DE UN FUNDAMENTO: ENTRE ESCEPTICISMO Y RAZÓN PROBLEMÁTICA}

Si la utopía no quiere cegar su doble apertura necesita un fundamento cual remitirse. Sin él no cabe auscultar imperiosas exigencias de futuro, capaces de romper la frontera de los tópicos consolidados. Tampoco es posible abrirse a la argumentación intersubjetiva sin un punto de referen-

6 Partiendo de la afirmación de J. Benntham de que "cada hombre ha de contar como uno y ningún hombre ha de contar como más de uno", R. M. Dworkin distingue entre la "preferencia personal por disfrutar de ciertos bienes y oportunidades" y la "preferencia externa por la asignación de bienes u oportunidades a otros". El resultado del juego de preferencias externas "altruistas o moralistas" sería "una especie de doble recuento". Defendiendo "la tesis liberal según la cual el Gobierno no tiene derecho a imponer por ley la moralidad popular", propone que sólo se tengan en cuenta las preferencias personales — Los derechos en serio- (Londres 1977), Barcelona, 1984, pp. 341-344. 
Este obra forma parte del acervo de la Biblioteca Jurídica Virtual del Instituto de Investigaciones Jurídicas de la UNAM www.juridicas.unam.mx

https://biblio.juridicas.unam.mx/bjv

cia común, por impreciso que fuere. El rechazo apriorístico de todo fundamento objetivo y razonable obliga — si es coherente- al silencio y empuja - a quien se autodispense de ello- a la logomaquia.

La búsqueda de un fundamento, al exigir un indulto respecto al delenda est metaphysica, tropieza con el ambiente teórico de descrédito de estos planteamientos, que se ha convertido en la práctica en defensiva actitud de terror. La aceptación teórica de la imposibilidad de una racionalidad práctica ${ }^{7}$ se ve frecuentemente acompañada de la curiosa convicción de que toda propuesta ética de fundamento no "débil" degenera, inevitablemente, en autoritarismo práctico. El despego displicente hacia la verdad se convierte en terror, ante una verdad cuyo anuncio suena a amenaza; al menos si se asume el prejuicio de que quien alude a la verdad es siempre con la insana intención de darnos con ella en la cabeza.

Este ambiente invita a camuflar las propuestas utópicas con un aderezo lo más "débil" posible. Alimenta, a la vez, el decidido acuerdo (la voluntad suplanta a la razón...) de no querer precisar en qué se está de acuerdo; se deja a las urgencias o habilidades de cada cual el sentido y el alcance con que podrá implementar a su favor el ya aludido tópico del "consenso".

Este indisimulable abandono a lo irracional encuentra hoy en dos doctrinas de mayor vigencia, vías de mitigación. Faltos de fundamento objetivo y razonable, quedamos al albur del poder arbitrario, sin que quepa otra defensa que convertirlo en formalmente condicionado o diseñarlo de un modo funcionalmente dosificado.

La primera de estas vías la ofrece la herencia kelseniana, en la medida en que se administra con el estoico rigor de su propio creador. Nos encontramos ante una curiosa teoría de la "doble verdad" que genera una utopía amputada. Las propuestas utópicas mantendrán su papel, animándonos - por ejemplo - a abismarnos en la esencia y valor de la democracia. Pero nos hallamos en el ámbito de una curiosa "verdad", que responde a una no menos curiosa "lógica": la de un emotivismo metarracional. Por un lado, una utopía "moral”, contrastada en más de una ocasión heroica o resignadamente (ante la represión que alimentaron utopías de no diversa consistencia racional, porque nos encontraríamos sumidos en una mera discrepancia de emociones...). Por otro lado, el ámbito racional y

7 A este rechazo de la metafísica y de la posibilidad de un razonamiento práctico hemos aludido en "Un realismo a medias: el empirismo escandinavo", ahora en Derechos humanos y metodología jurídica (nota 4), pp. 31 y 38. 
Este obra forma parte del acervo de la Biblioteca Jurídica Virtual del Instituto de Investigaciones Jurídicas de la UNAM www.juridicas.unam.mx

https://biblio.juridicas.unam.mx/bjv

científico (“"verdadero”?) del formalismo jurídico. Como en cualquier paralelismo riguroso, no hay entre ellos posible encuentro; salvo que surja de una coincidencia ocasional, sin duda "deseable" pero no más "racional" que su contraria. Convertir en una esta doble "verdad", disfrazando tal desaguisado como relectura kelseniana, sería un modo demasiado irrespetuoso de rendir culto al maestro.

No queda otra vía que la resignada aceptación del poder arbitrario, el ferviente deseo de que nos sea leve y el celo político para hacer factible en la práctica tan encomiable esperanza. La tarea no será fácil, porque se tratará con frecuencia de una arbitrariedad legitimada por los tópicos, que la blindan ante la erosión utópica. Quedará sólo el frágil cobijo de los condicionamientos jurídicos formales, capaces de someter lo arbitrario a nuevos controles que — por repetidos — hagan estadísticamente menos frecuente el atropello. Sirva de ejemplo arquetípico la "legislación negativa" propia del control constitucional "concentrado". Vincular este sistema al respeto del "contenido esencial" de los derechos fundamentales es una elocuente muestra del poco escrupuloso "kelsenismo" de nuestra Constitución, y obliga al Tribunal Constitucional a actuar más "positivamente" de lo que sería capaz de soportar tan prestigioso modelo.

Si este primer planteamiento lleva a una utopía amputada, al contar con un motor confesadamente irracional, el que pugna hoy por sustituirle abandona sin más toda utopía. Convierte a los derechos fundamentales —entendidos como "institución" - en mera terapia de frustraciones sociales. Luhmann es quien ahora toma el relevo, desmarcando al derecho del ámbito de la utopía crítica (más que como "verdad" emotiva, la trata ya como folklorismo tribal...) para diseñarlo como técnica de aprendizaje. El derecho domesticará a los ciudadanos, salvándolos de la neurosis a la que empujaría una "complejidad" no adecuadamente "reducida". Tomarse los derechos en serio sería empeñarse en mantener un modelo arcaico en una sociedad compleja. El tópico del "progreso científico" juega ahora con particular contundencia, aunque se disfrace con el lenguaje — presuntamente "débil" - de las alternativas metodológicas. Se producirá una apología de los "derechos", pero en la medida en que se muestran susceptibles de jugar como tópicos sociales de positivo rendimiento funcional.

Que estos "derechos fundamentales como institución"8 acaben sirviendo de cauce a una fecunda utopía sería un resultado ocasional como 
—en el modelo anterior- el posible encuentro entre la opción moral deseable y la forma jurídica indiscriminadamente disponible. Las ventajas funcionales van, más bien, de la mano de su virtualidad para entrenar en la insensibilidad, desdramatizador de frustraciones. De lo que se trata, ante todo, es de evitar que se conviertan en conflictivas las expectativas sociales no satisfechas; incluidas las que respondan a propuestas utópicas poco funcionales. El sociólogo ha dado paso a una lúcida descripción del paisaje social que resulta coherente para la arbitrariedad formalizada que diseñó el teórico del derecho. Pero cuando la sociología degenera en sociologismo y la propuesta metodológica en criptofilosofía normativa, se nos defiende implícitamente la renuncia ritualizada a la utopía en aras de una arbitrariedad funcionalmente dosificada.

El escepticismo pos-metafísico no parece dar para más. No faltará quien lo considera suficiente argumento para una deseable resurrección de signo opuesto. No en vano "positivismo" y "iusnaturalismo" llevan siglos actuando como plantas saprofitas, que reverdecen abrazadas al cadáver de su adversario. Pero si queremos eludir dilema tan poco ornamental, quizá podría resultar oportuno distanciarnos aparentemente del escenario filosófico, bloqueado por la pugna entre una razón resignada y unos tópicos autosatisfechos, acercándonos a los cotidianos afanes del jurista, empeñado en resolver problemas con el mayor asomo de razonabilidad.

\section{LA “INVENTIO” TÓPICA COMO INVITACIÓN}

A RECUPERAR LA UTOPÍA

Tras siglos de envidiar la racionalidad científica — identificada con la apoyada en un sistema de explicitarse more geometrico - los juristas se animaron a reexaminar su poco prestigiado arte de razonar. Éste invita a buscar, en la tópica urdida por sus lugares comunes, una autorizada razonabilidad decantada por la experiencia. Más que a la verificabilidad "positiva" — atribuida en sus momentos estelares a un sistema que pugnaba por convertirse en código - se aspira a la falsabilidad "negativa", que descarta la solución que no acaba convirtiéndose en común y tópica ante un núcleo problemático. 
Este obra forma parte del acervo de la Biblioteca Jurídica Virtual del Instituto de Investigaciones Jurídicas de la UNAM www.juridicas.unam.mx

https://biblio.juridicas.unam.mx/bjv

188

La primera consecuencia de este nuevo escenario sería la renuncia a "moralizar" — tan utópica como arbitrariamente - el ordenamiento jurídico desde instancias exteriores a él (resignada herencia del sistema formalista). La segunda, la rebeldía ante la conversión de la "reducción de la complejidad" en ética, tan confesadamente amoral como de obligado cumplimiento (receta del funcionalismo sistémico). La razón problemática invitaría, más bien, a bucear en la historicidad de los contenidos jurídicos, portadores de criterios de justicia propios, obligados a contrastarse una y otra vez ante las circunstancias sociales.

Reducir a mutabilidad social la historia es una de las vías que más eficazmente han llevado a malentender la historicidad de lo jurídico. Ésta no es el fruto de la proyección sucesiva de un contenido objetivo y acabado sobre una realidad social en continuo cambio. El contenido jurídico mismo porta su propia historicidad, dada la siempre problemática e inacabada explicitación de la inagotabilidad de implicaciones de lo inefable. ${ }^{9}$ El derecho no es contenido normativo perfilado de una vez por todas, listo para ser "aplicado" a la huidiza circunstancia histórica. Encierra un haz de principios, que han de ser una y otra vez recíprocamente ponderados ante la urgencia del problema social. Para ello se contará —entre otros puntos de referencia intersubjetiva- con el auxilio de la norma.

La tópica no puede oficiar, por tanto, como código alternativo promulgado a golpes de casuismo judicialista. Se ofrece más bien, como decantación histórica que atesora argumentaciones y soluciones explicitadoras de lo justo. El problema básico — la justicia o verdad de las soluciones propuestas o de los criterios a los que remiten- sigue abierto. La particular transparencia con que ayuda a reconstruir el debate utópico en trono a un problema es su principal virtud, y no ninguna piedra filosofal capaz de cerrarlo. Cuando dicha transparencia no se aprovecha para una enriquecedora reflexión, sólo nos queda un ciego casuismo amontonador de tópicos.

La razón problemática presupone la existencia de un fundamento, pero es a la vez consciente de que no "dispone" de él. No cabe, sin fundamento, aspirar al logro de una solución con sentido. Éste no surge como consecuencia de la aquilatada manipulación de unos contenidos precisos, disponibles para la aplicación casuística. Si se aspira a una solu-

9 Al respecto Lombardi-Vallauri, L., "Le droit comme moyen de communication de l'ineffable", en ed. por E. Castelli, Demitizzazione e ideologia, Padova, 1973, pp. 367 y ss. 
Este obra forma parte del acervo de la Biblioteca Jurídica Virtual del Instituto de Investigaciones Jurídicas de la UNAM www.juridicas.unam.mx

https://biblio.juridicas.unam.mx/bjv

ción objetiva es porque se presiente un objeto capaz de dar noticia de sí; aunque tan problemática que la feliz intuición subjetiva resulta escaso bagaje para su conquista. Por eso se aspira, a la vez, a una solución razonable; a alcanzarla a través de un discurso intersubjetivo, en el que el intercambio argumental marca el esfuerzo solidario por ahondar en la explicitación de lo inagotable. De ahí que cuando nuestro Tribunal Constitucional considera los derechos fundamentales como directamente aplicables, sin necesidad de una interpositio legislatoris,${ }^{10}$ está sin duda dejando en evidencia las limitaciones del normativismo jurídico, y certificando la rancia caducidad del positivismo legalista, pero sigue invitando a malentender el juego intrajurídico de la utopía. No hay derechos aplicables, ni estáticamente disponibles, sino asequibles a un discurso capaz de desentrañar en un contexto problemático sus exigencias, nunca definitivamente formuladas.

La tópica ayuda a recomponer el opaco circuito del discurso jurídico. La circularidad de la búsqueda de lo justo resulta expresivamente escenificada. Hacer justicia obliga a ser sensible a las exigencias de la igualdad, por ejemplo; pero no hay igualdad exigible frente a una desigualdad justificada; o sea legitimada por la justicia... ${ }^{11}$ Este recorrido hace aflorar los juicios de valor sobre el alcance teleológicamente "proporcional" de la desigualdad controvertida y los argumentos que la presentan como "razonable". La reflexión puede evitar el abandono al círculo vicioso, convirtiendo a la innegable circularidad del razonar jurídico en ocasión para una mutua crítica y un mutuo apoyo gubernamental. La forma procesal se convierte así en cauce para el discurso, evitando suplantarlo con una mera apariencia ritual. Nada tendrá de extraño, en consecuencia, que la utopía lleve a condenar una aplicación rígidamente formalista de los mecanismos procesales e invite incesantemente a la búsqueda de la interpretación más favorable para los derechos fundamentales ${ }^{12}$ en juego.

10 Mientras la extinta Audiencia Territorial de Sevilla incluía el artículo 14 de la Constitución entre las "meras enunciaciones de principios", y el Tribunal Supremo le reconocía el "alcance de una declaración de principio", la STC 80/1982 de 20 de diciembre, F.1, sentó "el reconocimiento de su carácter normativo" y su "vinculatoriedad inmediata" —Boletín Jurisprudencia Constitucional 1983 (21), p. 61. Cfr., también, STC 39/1983 de 17 de mayo, F. S-BJC 1983 (26) p. 669.

11 A ello nos hemos referido en "Principio de igualdad y teoría del derecho", ahora en Derechos humanos y metodología jurídica (nota 4), p. 275.

12 Entre otras, en la STC 34/1983 de 6 de mayo, F. 3 - BJC 1983 (26) p. 648- y la STC 67/1984 de 7 de junio, F. 3 -BJC 1984 (39), p. 917. 
Este obra forma parte del acervo de la Biblioteca Jurídica Virtual del Instituto de Investigaciones Jurídicas de la UNAM www.juridicas.unam.mx

https://biblio.juridicas.unam.mx/bjv

Paradójicamente, la tópica jurídica puede servir de filtro a la manipulación ideológica de los tópicos. Su razonabilidad problemática puede dar paso a una reflexión que los someta a examen y ayude a iluminar la teoría de la justicia que va subyacendo bajo un casuismo aparentemente casual o caprichoso. Dado que la actividad jurídica es - lo sepa o no el juristaantropología práctica, conviene ir fijando sus auténticos perfiles, para cobrar conciencia de ellos y someterlos a crítica. Convencerse de que los debates que rodean la interpretación de un texto jurídico son un mero entrecruce de alternativas metodológicas llevará a ignorar los modelos de lo humano que realmente se enfrentan tras los más socorridos tópicos. ${ }^{13}$

\section{DEBATE ANTROPOLÓGICO TRAS EL PRESUNTO CONSENSO SOBRE LOS DERECHOS HUMANOS}

Pocos elementos más expresivos de la exitosa conversión de la utopía de los derechos humanos en tópico que el cambio de actitud producido en el ámbito de la teoría marxista y los discursos políticos afines. El hiriente despego de los pasajes de La cuestión judía llega a verse sustituido hoy por interpretaciones o lecturas que parecen aspirar a situarse estratégicamente al abrigo de los tópicos forjados en la historia por tan denostada utopía. También la teoría de la "doble verdad" del formalismo jurídico ofrecía cobertura conformable, al permitir combinar el tópico legitimador "moral" (en clave revolucionaria, en este caso) y la arbitrariedad con honores de razón de Estado.

Sea cual sea la sinceridad y eficacia de la estrategia, se mantiene una constante antropológica: la negación de la persona como protagonista de la realidad histórica, al considerarse el hombre como mero resultado de las relaciones sociales. ${ }^{14}$ Del hombre, como sujeto activo, actor de la historia, capaz de un augere creativo, pasamos al hombre como destinatario pasivo de la realidad social, sujeto a necesidades y tributario de la estructura económica que asume su satisfacción. El hombre nuevo no podrá surgir de la autocrítica ética personal, sino que será el producto de una

13 Ilustrativo el análisis del debate argumental de la STC 22/1981 de 2 de julio; cfr. Derechos humanos y metodología jurídica (nota 4), pp. 275 y ss.

14 K. Marx, en su sexta Tesis sobre Feuerbach, apunta — criticando un insuficiente materialismo- "la esencia humana no es algo abstracto e inmanente a cada individuo. Es, en su realidad, el conjunto de las relaciones sociales" (trad. de W. Roces, como apéndice a La ideología alemana, 5a. ed., Barcelona, 1974, 667 pp.). 
Este obra forma parte del acervo de la Biblioteca Jurídica Virtual del Instituto de Investigaciones Jurídicas de la UNAM www.juridicas.unam.mx

https://biblio.juridicas.unam.mx/bjv

acertada planificación estatal. La legitimación de ésta se verá reforzada gracias a un "uso alternativo" de los derechos humanos, que pondrá especial énfasis en las prestaciones económicas, más que en las garantías civiles. Se compone así una peculiar utopía destinada a "moralizar" el ordenamiento jurídico hasta que, el día menos pensado, se haga al fin irreversiblemente superfluo.

Estos planteamientos continúan tropezando con una aportación histórica decisiva de la utopía de los derechos humanos. La experiencia resalta una y otra vez la irrenunciabilidad de las garantías formales como defensoras de la dignidad personal. Sin duda, no bastará con ellas para satisfacer las exigencias de la dignidad humana, pero su ausencia lleva a certificar infaliblemente su radical insatisfacción. Por la vía de la argucia estratégica o de la reforma ambiciosa, las más recientes propuestas apuntan, de un modo u otro, a un avance en la capacidad de asimilación de dichas exigencias por el llamado "socialismo real".

Si el dilema radical lo situamos en el enfrentamiento colectivismo-individualismo, las alternativas actuales vendrían establecidas sobre planteamientos menos distantes en realidad de lo que suelen aparentar. La discrepancia — que sitúa el centro de gravedad en lo individual o lo colectivo - pierde profundidad, al contar ambas propuestas antropológicas con un soterrado fundamento común: el economicismo. En su vertiente individualista no será tampoco la autocrítica ética personal el motor de la utopía, sino que la ética individual cederá ante la óptima asignación de recursos ofrecida por el mercado. De la profundidad de tal sintonía valga como síntoma la coincidencia en una de las propuestas más audaces del economicismo colectivista: el paulatino decrecimiento del derecho como factor de regulación social, sin que quepa descartar su desaparición definitiva. No otra cosa apunta el "análisis económico del derecho", mostrando la rentabilidad de sustituir categorías éticas (como culpa o responsabilidad) por cálculos de costes. La diferencia radica en el anatema dogmático que el economicismo colectivista esgrime contra el derecho tropieza con la envidiable salud que su estatalismo le presta, mientras que las recetas calculadas por el economicismo individualista se van abriendo paso sin gran aspaviento.

La conversión de la estructura económica en escenario auténtico del progreso de lo humano se erige en punto de partida común de ambos economicismos, falsamente alternativos. El marxista convertirá a la ética individual en mero subproducto; el economicismo individualista no llegará 
Este obra forma parte del acervo de la Biblioteca Jurídica Virtual del Instituto de Investigaciones Jurídicas de la UNAM www.juridicas.unam.mx

a tales profundidades, pero postulará un repliegue de la ética a lo privado, sometiendo lo público a meras exigencias de utilidad. No otra será la receta del funcionalismo sistémico, para el que la proyección de las opciones éticas personales sobre lo público llevaría a una "reducción de complejidad" excesivamente rígida e incapaz, por ello, de rentabilizar la deseable interdependencia de los subsistemas sociales.

Esta "despolitización" de lo público, con el correspondiente repliegue de utopías éticas, amenaza con frenar la proyección histórica de los derechos humanos y sirve de eco a otra experiencia básica de este proceso: la insuficiencia de un garantismo formal sin contenidos éticos. Sin garantías formales no cabe reconocimiento práctico de lo humano, pero sólo con ellas tampoco; sobre todo si se las ritualiza, sin reflexionar una y otra vez sobre su eficacia al servicio de los valores que históricamente las hicieron exigibles. De lo contrario, no cabe excluir que los mecanismos procedimentales acaben acarreando los más variados efectos perversos. Pueden llegar a cobrar un funcionamiento autónomo que lleve a sustituir en la práctica los valores a cuyo servicio juegan ${ }^{15}$ y pueden, incluso, cegar sobre las consecuencias que derivan de la mera inhibición personal o institucional a la hora de activarlos. La forma procesal es cauce insustituible de la ética como motor utópico, pero puede a su vez degenerar en una "legitimación por el procedimiento" 16 que acabe adormilando todo asomo de invitación ética a la utopía.

El común fundamento economicista de estos planteamientos, presuntamente alternativos, puede quizá arrojar luz sobre una de las consecuencias más llamativas del reciente balance de bicentenario. La triple utopía libertad-igualdad-fraternidad se muestra ostensiblemente amputada. Libertad e igualdad parecen buscar abrigo en sus respectivos referentes economicistas, dejando a la fraternidad en llamativo desamparo. Conscientes de las aportaciones irreversibles de lo moderno, parece obligado no cerrar los ojos ante sus obvias "valencias negativas". ${ }^{17}$ Ninguna lo sería tanto como la que llevara a olvidar que la fraternidad solidaria es una dimensión ineludible de la utopía de lo humano.

15 Sobre ello nuestro reciente trabajo Igualdad en la aplicación de la ley y precedente judicial, Madrid, 1989, pp. 51 y ss.

16 Luhmann, N., Legitimation durch Verfahren, Neuwied, 1969. Sobre su alcance los trabajos citados en las notas (5) y (8).

17 Cfr. Lombardi-Vallauri, L., Abortismo libertario e sadismo, Milán, 1976, pp. 65 y ss. 
Este obra forma parte del acervo de la Biblioteca Jurídica Virtual del Instituto de Investigaciones Jurídicas de la UNAM www.juridicas.unam.mx

https://biblio.juridicas.unam.mx/bjv

Se hace preciso revisar estas bases antropológicas, para detectar en ellas insuficiencias radicales. El economicismo atomiza a los sujetos, sea cual sea su valoración teórica de lo individual, marginando así la "paridad ontológica" 18 fundamentadora de lo jurídico. Ésta no puede dejar de hacerse presente, sin necesidad de que tal fundamento llegue a ser consciente. Así ocurre cuando el Tribunal Constitucional señala, una y otra vez, que "no existen derechos ilimitados" ${ }^{19}$ En el marco de una paridad ontológica, el derecho es siempre libertad ajustada, y ninguna pretensión desmesurada puede considerarse "jurídica". Cuando falta la conciencia de dicho fundamento, se llega, sin embargo, a esgrimir los derechos no para servir de cauce a un ajustamiento de libertades sino para poder liberarse o desembarazarse de los otros. Nada expresa de modo más gráfico nuestro actual déficit de solidaridad social que la eufemística "interrupción voluntaria del embarazo" al amparo de distingos legales.

Paridad-fraternidad-solidaridad componen el más grave déficit histórico de la utopía de los derechos humanos. Sin tal elemento, acecha de continuo la tentación de la igualdad uniformista o de la libertad desembarazada. Para que haya ajustamiento de libertades, el derecho ha de realizar su papel antropológico como posibilitador de una coexistencia personal. Ésta desborda cualquier intento de coincidencia mecanizada, venga ésta impuesta autoritariamente, programada funcionalmente o calculada económicamente. Lejos de ser resultado mecánico, la coexistencia condiciona éticamente los mecanismos procedimentales. Si la solidaridad mantiene la apertura de la utopía al futuro — evitando que acabe enclaustrada en tópicos autosatisfechos- ese mismo fundamento descarta la segunda posible cerrazón, al convertir en exigencia ética la apertura al discurso. La utopía ha de seguir fluyendo gracias a un "uso reflexivo" de los derechos humanos, en el que el tópico no cierre el paso al argumento que la dignidad ajena reclama.

La invocación revolucionaria a la fraternidad resulta especialmente ilustrativa, a la hora de diagnosticar la precariedad histórica de la paridad ontológica y de su correlativa solidaridad civil. Problemática fraternidad a la que busca apoyo en un padre común obtenido in vitro. El Estado, padre ortopédico fabricado por la modernidad, parece más diseñado para garantizar ámbitos de libertad (no siempre ajustada) o para imponer la igualdad (no pocas veces uniformada) que para servir de cauce a una fra-

19 Por ejemplo, en la STC 2/1982 de 29 de enero, F. 5 - BJC 1982 (10), p. 102. 
Este obra forma parte del acervo de la Biblioteca Jurídica Virtual del Instituto de Investigaciones Jurídicas de la UNAM www.juridicas.unam.mx

ternidad mínimamente convincente. Esta evidencia invita, sin duda, a revisar alguno de los tópicos apuntados al principio, evitando la imposición de modelos de "pluralismo" lastrados por exigencias que les condenan a resultar inevitablemente insolidarios.

\section{CÓMO PONER A SALVO DE LOS TÓPICOS A LA UTOPÍA}

Los recientes aniversarios invitan a conjurar un grave peligro: la degeneración de la utopía de los derechos humanos en un conjunto de tópicos que se pueden implementar. De ahí que mantener abierta la utopía exige una actitud personal que no excluya, entre otros, estos esfuerzos:

- Buscar detrás de cada alusión tópica su trasfondo antropológico, movidos por el decidido acuerdo de saber siempre si, y en qué, estamos de acuerdo;

- Convertir - gracias a un esfuerzo argumentador - en alusión tópica obligada las exigencias solidarias de los derechos humanos, hoy netamente deficitarias;

- Dar paso a un "uso reflexivo" del ordenamiento jurídico, ${ }^{20}$ que ayude a recordar que la pasividad ante los derechos humanos equivale a su traición; que anime a asumir la ineludible ponderación de principios que ello lleva consigo, evitando así la cómoda resignación ante presuntos imponderables; que invite a sopesar el juego axiológico cumplido en cada caso por los mecanismos procesales...

- Abrir la cotidiana tópica jurídica, mediante una transparencia argumental que permita convertirla en una utopía atesoradora de exigencias de lo humano. Ello nos hará conscientes de lo rechazable de un planteamiento de "doble verdad", que legitima la función narcotizadora de la ideología condensada en tópicos acríticamente asumidos.

20 Comentando el consejo "filosófico" de N. Bobbio, que anima a invertir en la defensa de los derechos humanos las energías malgastadas en intentar fundamentarlos, F. d'Agostino señala agudamente que "los derechos humanos no se defienden con meras declamaciones verbales e iluministas, sino con una paciente y reflexiva actividad de intervención en la praxis" — "Ancora sulla razionalità del diritto naturale: l'esempio dei diritti dell'uomo", Diritto e secolarizzazione, Milán, 1982, p. 168. 
Nada más eficaz para hacer imposible estos objetivos que una demonización de lo moderno, que lleve a comportarse como si jugara en campo ajeno a quien se halla en envidiables condiciones para actuar como "experto en humanidad". ${ }^{21}$ Esto no encierra ninguna peculiar invitación a incurrir en actitudes "fundamentalistas", sino la llamada a asumir un imperativo constitucional. El que nos impone la honrosa carga de garantizar el "contenido esencial" de los derechos humanos y de hacer reales y efectivas sus exigencias éticas, por más que ello obligue a desafiar — contra corriente - la tolerancia represiva de los antifundamentalismos estéticos.

21 De ello nos ocupamos en nuestro trabajo Expertos en humanidad. Convicciones religiosas y democracia pluralista con el que colaboramos al volumen de estudios en preparación sobre la ya citada encíclica Sollicitudo rei Socialis. 


\title{
¿SIRVE EL CONSENSO PARA FUNDAMENTAR LOS DERECHOS HUMANOS? UN BREVE ANÁLISIS A DOS INTENTOS DE FUNDAMENTACIÓN DE LOS DERECHOS HUMANOS DESDE EL CONSENSO (NORBERTO BOBBIO Y CHAÏM PERELMAN)
}

\author{
Javier SALDAÑA SERRANO
}

\begin{abstract}
SUMARIO: I. Planteamiento del problema. II. La constante del fundamento. III. Planteamiento general de la tesis de Norberto Bobbio. IV. Planteamiento general de la tesis de Chaïm Perelman. V. Conclusión. VI. Bibliografía.
\end{abstract}

\section{PLANTEAMIENTO DEL PROBLEMA}

Uno de los temas más importantes en el discurso filosófico-jurídico de la modernidad ha sido, sin duda, el relativo a los derechos humanos; tema este que, particularmente después de la Segunda Guerra Mundial, adquirió una nueva revitalización a raíz del genocidio alemán, e hizo resurgir además el intento iusnaturalista por fundamentar estos derechos, por eso, con justificada razón se ha escrito

que el final de la Segunda Guerra Mundial marca un hito en la historia de la filosofía jurídica, que viene determinado por el socavamiento de los dogmas del XIX y la subsiguiente reedición de viejas polémicas, no diremos superadas, pero sí claramente abandonadas por el pensamiento decimonónico, en el que predominaron a todas luces los enfoques histórico y dogmático sobre el filosófico, dentro de los estudios jurídicos. Sin duda alguna, los temas antiguos que ahora resurgen con fuerza —el de la metodología, el de las fuentes del derecho, etcétera- observan entre sí una estrecha relación teórica, aunque cabe encontrar en la raíz común a todos ellos el viejo problema del derecho natural. ${ }^{1}$

1 Serna Bermúdez, P., Positivismo conceptual y fundamentación de los derechos humanos, Pamplona, Eunsa, 1990, pp. 13-14. 
Este obra forma parte del acervo de la Biblioteca Jurídica Virtual del Instituto de Investigaciones Jurídicas de la UNAM www.juridicas.unam.mx

Como lo mencionamos, uno de estos temas es el relativo a los derechos humanos, cuyo discurso, lamentablemente, ha estado durante muchos años alimentado por una profunda carga emocional motivada por el contenido mismo que la expresión significa, de tal manera que hoy utilizamos la locución "derechos humanos" casi para cualquier cosa. Lo mismo llamamos derecho humano al derecho a la vida que todo hombre posee, que el derecho que tienen los padres de determinar el sexo o cualidades físicas de sus futuros hijos; igualmente, la empleamos para calificar el derecho a la libertad de las personas, que para justificar los derechos de los homosexuales a contraer matrimonio y adoptar niños, ${ }^{2}$ convirtiendo este término muchas veces en parte de una ideología bajo la que se pretenden justificar ciertos intereses que nada tienen que ver con lo que realmente son los derechos humanos. ${ }^{3}$ ¿Son tan ambiguos los derechos humanos?

A la anterior pregunta ha intentado responder uno de los apartados que integran lo que podríamos denominar "discurso iusfilosófico de los derechos humanos", concretamente la fundamentación de estos derechos.

\section{LA CONSTANTE DEL FUNDAMENTO}

Cuando centramos nuestra atención en el tema de la fundamentación de los derechos humanos es necesario formularnos la siguiente pregunta: ¿qué significa fundamentar?; precisando aún más, ¿qué significa fundamentar un derecho humano?

Es claro que la expresión "fundamentación" parece denotar el sustento objetivo de las cosas. Fundamentar, en el orden del conocimiento práctico, es la justificación racional que sostiene una afirmación. En el caso particular del derecho, cuando hablamos de la fundamentación de éste tenemos que referirnos, como lo hace Guasp, a que la misma no puede hallarse en lo sustancialmente jurídico (nos referimos al derecho positivo), porque es una regla lógica que nada se apoya sobre sí mismo, sino en otra realidad ajena, la cual, justamente por serlo, es la única que le puede servir de sustento. ${ }^{4}$ De este modo, en el campo jurídico esta justifi-

2 Para una visión general de los problemas que presenta el tema de la homosexualidad y el derecho, cfr. Samar, J. V., The Right to Privacy. Gays, Lesbians, and the Constitution, Philadelphia, Temple University Press, 1991; Sander, D., "Getting Lesbian and Gay Issues on the Human Rights Agenda”, Human Rights 1. V. 18, E.U.A., 1996.

3 Cfr. Massini Correas, C. I., El derecho. Los derechos humanos y el valor del derecho, Buenos Aires, Abeledo-Perrot, 1987, pp. 135-137.

4 Cfr. Guasp Delgado, J., Derecho, Madrid, Hergon, 1971, pp. 289-290. 
Este obra forma parte del acervo de la Biblioteca Jurídica Virtual del Instituto de Investigaciones Jurídicas de la UNAM www.juridicas.unam.mx

https://biblio.juridicas.unam.mx/bjv

cación racional que se pregona nunca podra ser lo puramente normativo sino una realidad objetiva $\mathrm{y}$, por tanto, diferente a lo meramente formal del derecho.

Colocados en el terreno de los derechos humanos, parece que fundamentar éstos sería la búsqueda de "ciertas afirmaciones o principios [...] que, en razón de aparecer como evidentes, justifiquen racionalmente, por la vinculación lógica necesaria con ellos, las afirmaciones acerca de la existencia y extensión de los derechos humanos".5 Así, "no sería posible [...] recurrir a enunciados de principios aceptados por mera convención" ${ }^{6}$ En definitiva, la fundamentación de los derechos humanos no es sino la labor que permite distinguir qué hay de objetividad en ellos y qué de ideología. ${ }^{7}$ En esta realidad objetiva es donde, según parece, es posible comenzar a buscar la respuesta al problema que plantea el fundamento de los derechos humanos. Así, en el terreno de los derechos, el fundamento de los que calificamos como "humanos" lo encontraremos, según el sentido anterior, en aquella realidad objetiva que ellos mismos manifiestan.

\section{PlanteAmiento GENERAL DE LA TESIS DE NORBERTO BobBIO}

Sin embargo, la idea anterior parece no ser compartida por buena parte de los teóricos que se han dedicado a hablar sobre tales derechos y particularmente sobre su filosofía. Éste es el caso del profesor italiano Norberto Bobbio, para el cual hablar sobre la fundamentación de los derechos humanos no depende de algo objetivo, sino del consenso al que intersubjetivamente se llegue. Nos dice el profesor de Turín que "buscar fundamento a los derechos humanos es aducir motivos para justificar la elección que hemos realizado y que querríamos realizaran también los demás". ${ }^{8}$ Así, "la única prueba por la que un sistema de valores puede ser considerado como humanamente fundado $\mathrm{y}$, por tanto, reconocido, es la prueba del consenso general acerca de su validez". ${ }^{9}$ Finalmente, señala el profesor italiano:

5 Massini Correas, C. I., Filosofía del derecho. El derecho y los derechos humanos, Buenos Aires, Abeledo-Perrot, 1994, p. 104.

6 Ibidem.

7 Cfr. Serna Bermúdez, P., op. cit., nota 1, p. 147.

8 Bobbio, N., "Sul fondamento dei diritti dell'uomo", Il problema della guerra e le vie della pace, Bologna, Il Mulino, 1979, p. 121.

9 Cfr. Bobbio, N., "Presente y porvenir de los derechos humanos", Anuario de Derechos Humanos 1, Madrid, Servicio de Publicaciones de la Universidad Complutense de Madrid, 1982, p. 10. 
Este obra forma parte del acervo de la Biblioteca Jurídica Virtual del Instituto de Investigaciones Jurídicas de la UNAM www.juridicas.unam.mx

https://biblio.juridicas.unam.mx/bjv

se entiende que la exigencia del respeto a los derechos humanos y las libertades fundamentales nace de la convicción generalmente compartida de que ya están fundados: el problema del fundamento es ineludible. Pero cuando digo que el problema cada vez más urgente frente al que nos encontramos no es el problema del fundamento, sino el de las garantías, quiero decir que consideramos el problema del fundamento no como inexistente sino como, en cierto sentido, resuelto de tal modo que no debemos preocuparnos más por su solución. En efecto - continúa el referido autor-, hoy se puede decir que el problema del fundamento de los derechos humanos ha tenido su solución en la Declaración Universal de Derechos Humanos aprobada por la Asamblea General de Naciones Unidas el 10 de diciembre de $1948 .{ }^{10}$

De modo que buscar un fundamento absoluto carece, a su vez, de fundamento. ${ }^{11}$

Para Bobbio, existen tres posibles formas de fundar los valores: primera, deducirlos de un dato objetivo constante, por ejemplo, la naturaleza humana; ${ }^{12}$ segunda, considerar los valores como verdades evidentes; ${ }^{13}$ tercera, la opción de consenso: describir que en un determinado periodo de la historia son generalmente consensuados (la prueba, precisamente, del consenso). ${ }^{14}$

10 Idem. En esta misma línea de pensamiento podríamos incluir a Rabossi, quien considera que "Luego de esta descripción impresionista creo que no es necesario ofrecer ningún argumento para afirmar la existencia en nuestro mundo actual de un fenómeno específico, históricamente dado, sumamente complejo, extraordinariamente dinámico, de alcances universales y de consecuencias revolucionarias. A este fenómeno lo denominaré el fenómeno de los derechos humanos". Rabossi, E., "El fenómeno de los derechos humanos", Ética, política y derecho, México, UNAMSiglo XXI, 1991, p. 205.

11 Cfr. Bobbio, N., L'Età dei diritti, trad. cast. R. de Asís Roig, Madrid, Sistema, 1991, p. 54.

12 La objeción que observa el profesor italiano es la imposibilidad noseológica de dicha categoría. Explica: "El primer modo nos ofrecería la mayor garantía de su validez universal si realmente existiera la naturaleza humana y, admitido que exista como dato constante e inmodificable, nos fuera dado conocerla en su esencia: a juzgar por la historia del iusnaturalismo, la naturaleza humana ha sido interpretada de los modos mas diversos, y la apelación a la naturaleza ha servido para justificar sistemas de valores incluso opuestos entre sí [...]". Bobbio, N., "Presente y porvenir de los derechos humanos", Anuario..., op. cit., p. 10.

13 "El segundo modo — la apelación a la evidencia - tiene el defecto de presentarse más allá de toda prueba y rechazar cualquier otra posible argumentación de carácter racional: en realidad, apenas sometemos a la verificación histórica valores proclamados como evidentes nos damos cuenta de que lo que ha sido considerado como evidente por algunos en un momento dado ya no se considera evidente por otro en otro momento [...] Actualmente, ¿quién no piensa que es evidente no torturar a los detenidos? Y sin embargo durante muchos siglos la tortura fue aceptada y defendida como un procedimiento judicial normal [...]". Ibidem, p. 11.

14 "El tercer modo de justificar los valores es mostrar que están apoyados en el consenso, según el cual un valor estaría tanto más fundado cuanto más compartido fuese. Con el argumento del 
Este obra forma parte del acervo de la Biblioteca Jurídica Virtual del Instituto de Investigaciones Jurídicas de la UNAM www.juridicas.unam.mx

https://biblio.juridicas.unam.mx/bjv

Estas expresiones nos muestran cómo en la exposición de Bobbio "gravita una cierta duda sobre la posibilidad práctica y teórica de la objetividad, aunque no se da una rechazo total" ${ }^{15}$ En definitiva, según el pensamiento de este autor, el fundamento absoluto es una ilusión. ${ }^{16}$

\section{Observaciones a la tesis presentada por Norberto Bobbio}

Qué duda cabe lo atrayente que resultan las anteriores afirmaciones. Es claro que, ante la frecuente violación a los derechos humanos, observada hoy en los distintos lugares con las más diversas ideologías, lo más apremiante para ellos sea su efectiva y real protección, aceptada la fundamentación de estos en el consenso generalizado. Sin embargo, aunque en un primer momento resulte sugestivo este intento de fundamentación (que calificamos como consensualista), hay una serie de objeciones de carácter filosófico que convendría tener en consideración antes de aceptar con tanta simpleza de razón dicha tesis.

En este sentido, me parece que la pregunta obligada sería: ¿cabe la posibilidad de que el consenso pueda constituirse en un modo de fundamentar (en el sentido que hemos dejado anunciado) los derechos humanos tal y como lo plantea Bobbio? Parece que la anterior pregunta podría ser respondida, según la postura manifestada por Bobbio, del siguiente modo: "[...] las mismas afirmaciones de Bobbio hacen desaparecer la posible validez del consenso como fundamento en el sentido clásico [...]". ${ }^{17}$ El porqué, lo veremos a continuación. En este sentido, se pueden observar claramente al menos dos importantes deficiencias de la tesis planteada.

a) Subjetivización en los derechos humanos

La primera deficiencia de la fundamentación bobbiana salta a la vista. Si por fundamentación hemos entendido aquel dato objetivo de los derechos humanos al que antes nos hemos referido, es evidente que el argumento consensualista jamás podrá invocar ninguna realidad objetiva para

consenso se sustituye la prueba de la objetividad — considerada imposible o extremadamente incierta - por la de la intersubjetividad [...]". Ibidem.

15 Serna Bermúdez, P., op. cit., nota 1, p. 147.

16 Cfr. Bobbio, N., op. cit., nota 11, p. 55.

17 Serna Bermúdez, P., op. cit., nota 1, p. 147. 
Este obra forma parte del acervo de la Biblioteca Jurídica Virtual del Instituto de Investigaciones Jurídicas de la UNAM www.juridicas.unam.mx

https://biblio.juridicas.unam.mx/bjv

la defensa de estos derechos; más bien lo contrario, encontrará su fundamento en un dato que se hace depender del común acuerdo entre los miembros de una sociedad, relativizando los derechos y considerándolos como una simple ideología, personal o de grupo.

$\mathrm{Si}$ son coherentes quienes defienden la tesis del consenso, tendrían que aceptar que tanto los derechos humanos, como la dignidad de la persona (sustento de estos últimos) son una ideología, "algo apetecible pero sólo subjetivamente apetecible, subjetivamente valioso, pero no universalmente valioso, no valioso de suyo" ${ }^{18}$

De este modo, para esta teoría, los derechos humanos no pasarían de ser valores, aspiraciones o sentimientos cambiantes, relativos en el tiempo y dependientes de ciertas circunstancias sociales, ${ }^{19}$

con esta idea los derechos humanos se derrumban, pues basta que en un medio social se desarrollen en un modo suficientemente mayoritario unos sentimientos, valoraciones o ideologías contrarios a los derechos humanos (v. $g r$. el racismo, el esclavismo o el abortismo) para que esos derechos humanos - al desaparecer como valores - desaparezcan, con lo que su contravención dejaría de ser una injusticia, una tiranía y una opresión. ${ }^{20}$

Si esto es así, la propuesta consensualista parece que nos tiene que llevar a aceptar la tesis de que la dignidad de la persona, que en este momento es valiosa, mañana puede no serlo, de ahí que

quienes enarbolan la bandera de la dignidad humana no tienen derecho a hacerla actuar como concepto resorte que impida avanzar hacia el futuro; el consenso de hoy no puede ni tiene por qué condicionar el de mañana ni las posibles disidencias, al menos legítimamente, porque no se puede impedir una modificación del presente en nombre de un concepto que es esencialmente revisable incluso para quienes lo entienden y, en este caso, toda política destinada a consagrar los derechos humanos y la dignidad humana es fuerza y violencia, al menos hacia la generaciones futuras y las minorías

18 Idem.

19 En este sentido, me prece que existe una íntima coincidencia entre la tesis planteada por Bobbio, tal y como la hemos desarrrollado anteriormente y el intento historicista de fundamentación de los derechos humanos, es decir, aquella propuesta que concibe a los derechos humanos variables y relativos en cada contexto histórico que el hombre tiene y mantiene de acuerdo con el desarrollo de la sociedad. Cfr. Fernández, E., "El problema del fundamento de los derechos humanos", Anuario..., op. cit., nota 9, pp. 92-93.

20 Hervada, J., Escritos de derecho natural, 2a. ed., Pamplona, Eunsa, 1993, pp. 656 y ss.; ibidem, "Los derechos inherentes a la dignidad de la persona humana", Humana Iura 1, Pamplona, 1991, pp. 350 y ss. 
Este obra forma parte del acervo de la Biblioteca Jurídica Virtual del Instituto de Investigaciones Jurídicas de la UNAM www.juridicas.unam.mx

https://biblio.juridicas.unam.mx/bjv

del presente — ¿cómo fundar desde aquí los derechos de las minorías?$[\ldots] .{ }^{21}$

Efectivamente, en esta primera impugnación, los argumentos del modelo consensualista manifiestan la imposibilidad de fundar los derechos humanos desde el concepto de dignidad. Ésta no puede hacerse depender de lo que intersubjetivamente puedan querer en determinado momento un grupo de personas por más que se califiquen como consenso, porque el fundamento de los derechos no puede ser una ideología plural. Por eso, es cierto que, de aceptarse como fundamento de estos derechos la dignidad de la persona, parece necesaria la admisión también de la objetividad de ésta y el rechazo de lo intersubjetivo y relativo, pues esto representa un simple hecho: el consenso de las personas. Ahora bien, si, por el contrario, no se acepta que dicho fundamento es la dignidad personal, sino la decisión intersubjetiva a la que se llega, no podría emplearse la dignidad como dato objetivo, tendría que utilizarse otro concepto diferente de ésta; tendría que ser ésta una noción subjetiva, relativa, posibilitada para ser cambiante en el transcurso del tiempo y exclusivamente útil para los agrados colectivos o intersubjetivos.

b) ¿Aceptación generalizada de los derechos humanos?

Una segunda objeción a la tesis planteada por Bobbio vendría dada por la presunta aceptación generalizada de los derechos humanos al considerar que

sólo después de la Declaración podemos tener la certidumbre histórica de que la humanidad, toda humanidad, comparte algunos valores comunes y podemos creer finalmente en la universalidad de los valores en el único sentido en que tal creencia es históricamente legítima [...]. ${ }^{22}$

A esta tal afirmación se puede decir que "ante un planteamiento tan optimista como el del profesor de Turín, cabe objetar que la constante violación actual de los derechos humanos muestra la falta de arraigo y la precariedad de esas pretendidas convicciones generalmente compartidas y la consiguiente necesidad de seguir argumentando filosóficamente en su favor $(\ldots) " .23$

21 Serna Bermúdez, P., op. cit., nota 1, pp. 147-148.

22 Bobbio, N., "Presente y porvenir de los derechos humanos", Anuario..., op. cit., nota 9, p. 12.

23 Pérez Luño, A. E., Derechos humanos, Estado de derecho y Constitución, 4a. ed., Madrid, Tecnos, 1991, p. 133. 
Este obra forma parte del acervo de la Biblioteca Jurídica Virtual del Instituto de Investigaciones Jurídicas de la UNAM www.juridicas.unam.mx

https://biblio.juridicas.unam.mx/bjv

Efectivamente, si existiera una creencia generalizada acerca de la existencia y posesión de estos derechos por parte de las personas, habría que dar una solución a la siguiente interrogante: ¿por qué son tan frecuentes las violaciones a estos derechos? Por otro lado, baste observar la diversidad de argumentos filosóficos que encontramos en los distintos sistemas políticos para darnos cuenta de que este fundamento no es tan común ni tampoco tan generalmente aceptado. ${ }^{24}$ En todo caso, lo que parece válido aceptar es que, con el acuerdo alcanzado en la Declaración Universal de las Naciones Unidas, se nos explica cómo se ha llegado a consentimiento, pero no se responde a la razón de ser de éstos, es decir, su por qué. ${ }^{25}$.

Sobre esta última idea apuntada cabría advertir igualmente que el consenso al que llegó la Asamblea General de la ONU (ese cómo y no por qué) no fue un consenso teórico o filosófico, sino un acuerdo eminentemente práctico; fue, en definitiva, un consenso válido sólo fácticamente, pero no filosóficamente. El acuerdo fáctico no nos dice sino que

se trata de un acuerdo práctico, en el que es fácil coincidir; pero eso no significa acuerdo teórico y, aunque es verdad que se tuvieron buenas razones para aceptar esos derechos, resulta que fueron distintas. Es fácil ponerse de acuerdo en cuanto a la praxis, máxime cuando se trata de cosas tan necesarias, la integridad, la salud, la libertad, etcétera, pero no puede olvidarse que la praxis se fundamenta en la teoría. ${ }^{26}$

La Asamblea General y la Declaración a la que llegó el 10 de diciembre en París representa exclusivamente la preocupación universal por proteger los derechos humanos, pero no el consentimiento teórico acerca de los mismos. ${ }^{27}$

24 Idem.

25 Idem.

26 Beuchot, M., Filosofía y derechos humanos (los derechos humanos y su fundamentación filosófica), México, Siglo XXI, 1993, p. 158; idem, Derechos humanos. Iuspositivismo y iusnaturalismo, México, UNAM, 1995, pp. 123-135.

27 Baste recordar los fuertes debates que se llevaron a efecto en el seno de las Naciones Unidas para la aprobación de cada uno de los artículos que integran la Declaración. Así, por ejemplo, el artículo 18, relativo a la libertad religiosa, tuvo más de ocho propuestas antes de llegar a su aprobación definitiva. Cfr. Verdoot, A., Naissance et signification del la Déclaration Universelle des Droits de l'Homme, trad. cast. Arzálluz, J., Bilbao, Mensajero, 1969, p. 173; Truyol y Serra, A., Los derechos humanos. Declaraciones y convenios internacionales, 3a. ed., Madrid, Tecnos, passim; AA.VV., Veinte años de evolución de los derechos humanos, México, UNAM, 1974, passim. 
Este obra forma parte del acervo de la Biblioteca Jurídica Virtual del Instituto de Investigaciones Jurídicas de la UNAM www.juridicas.unam.mx

https://biblio.juridicas.unam.mx/bjv

En este sentido, parece acertada la idea que distingue entre el problema estrictamente filosófico de los derechos humanos y el de índole puramente política. Aunque ambos problemas (fundamentación y praxis) sean distintos, es difícil establecer una diferenciación radical entre ambos si se quieren proteger estos derechos; "no sólo es contar con las técnicas jurídicas que los garanticen [...], sino también estar respaldados por buenos argumentos a la hora de fundamentarlos y defenderlos". ${ }^{28}$

A manera de resumen de lo dicho hasta ahora, podríamos decir que, a pesar del intento que Bobbio propone por reconocer en el consenso la posible solución al problema que plantea el fundamento de los derechos humanos, es claro que dicha postura resulta difícil de aceptar en tanto queden sin resolver las objeciones planteadas. Primero, el problema que plantea la subjetividad a la que nos lleva dicha posición, que no es sino dejar a la voluntad, es decir, a la arbitrariedad la solución del fundamento; segundo, según hemos visto, parece que la diversidad de concepciones sobre lo que son los derechos humanos nos hacen ver lo utópico de esta posición.

\section{PlanteAmiento GENERAL DE LA TESIS DE CHAÏM PERELMAN}

Otro intento propuesto para fundamentar los derechos humanos desde el consenso es el formulado por el filósofo belga Chaïm Perelman. ${ }^{29} \mathrm{En}$ términos generales, podemos incluir la teoría de Perelman dentro de los diversos intentos que buscan encontrar una racionalidad para el derecho, particularmente en la decisión judicial a través de la argumentación jurídica. ${ }^{30}$ "El medio elegido para dicha justificación no va a ser el de la legitimación por una justicia a priori, metafísica, sino el de una racionalidad de particulares contornos". 31

28 Fernández E., Teoría de la justicia y derechos humanos, Madrid, Debate, 1991, pp. 83 y ss.

29 Para el objeto de este artículo utilizaremos el trabajo de Perelman: "Peut-on fonder les droits de l'homme"? en Droit, Morale et Philosophie, 2a. ed., París, Librairie Générale de Droit et de Jurisprudence, 1976, pp. 67-73. La exposición y comentarios que hagamos del pensamiento del autor belga lo transcribimos de la explicación que se hace de éste en: Serna Bermúdez, P., Positivismo conceptual..., op. cit., pp. 165-192.

30 Sólo por mencionar dos de sus trabajos sobre este tema, podemos citar: Perelman, Ch., Le champ de l'argumentation, Bruxelles, P.U.B., 1970, passim; idem, Traitè de l'argumentation. La Nouvelle rètorique, 2a. ed., Bruxelles, Université de Bruxelles, 1976, passim.

31 Serna Bermúdez, P., op. cit., nota 1, p. 168. 
Perelman intenta colocarse en una postura intermedia entre el derecho natural y el derecho positivo para la justificación del derecho. Critica cualquier planteamiento metafísico del derecho, pero tampoco acepta que la explicación del mismo pueda ser plenamente satisfecha por el positivismo jurídico, ya sea en el plano teórico como en el práctico. ${ }^{32}$

Perelman no emplea la racionalidad como medio de justificar el derecho pues considera que esta expresión, en última instancia, nos llevaría a una idea de verdad y, en último extremo, a lo metafísico en el derecho. Noción ésta, como todos sabemos, despreciada en los tiempos modernos. ${ }^{33}$ En este sentido, prefiere utilizar el concepto de lo razonable, que se presenta como lo cierto de hecho, con un marcado acento empírico. Es así como entra de nuevo en la escena la idea del consenso. El consenso de la comunidad es el ámbito donde surge lo razonable. ${ }^{34}$ "La categoría específica del pensar jurídico es la razonabilidad, y ésta viene, de un modo u otro, determinada por el consenso, tácito o explícito, ideal o fáctico, la ciencia jurídica debe constituirse como ciencia de la argumentación, de la persuasión, del convencimiento, es decir, como una nueva retórica" . ${ }^{35}$

32 Perelman, Ch., "Peut-on fonder les droits de l'homme"?, op. cit., nota 29, pp. 67-69.

33 Cfr. Massini Correas, C. I., La desintegración del pensar jurídico en la Edad Moderna, Buenos Aires, Abeledo-Perrot, 1980, pp. 13 y ss.

34 Serna Bermúdez, P., Positivismo conceptual..., op. cit., nota 1, p. 170.

35 Ibidem, p. 171. Haciendo un poco de historia, podemos señalar que el antecedente de la filosofía propuesta por Perelman podemos encontrarla en Aristóteles. El estagirita, en el libro primero, capítulo primero de los Tópicos, señalaba: "El propósito de este estudio es encontrar un método a partir del cual podamos razonar sobre todo problema que se nos proponga, a partir de cosas plausibles, y gracias al cual, si nosotros mismos sostenemos un enunciado, no digamos nada que le sea contrario. Así, pues, hay que decir primero qué es un razonamiento y cuáles sus diferencias, para que pueda comprenderse el razonamiento dialéctico [...].

Un razonamiento es un discurso (logos) en el que sentadas ciertas cosas, necesariamente se da a la vez, a través de lo establecido, algo distinto de lo establecido. Hay demostración cuando el razonamiento parte de cosas verdaderas y primordiales, o de cosas cuyo conocimiento se origina a través de cosas primordiales y verdaderas; en cambio, es dialéctico el razonamiento construido a partir de cosas plausibles. Ahora bien, son verdaderas y primordiales las cosas que tienen credibilidad, no por otras, sino por sí mismas [...]; en cambio, son cosas plausibles las que parecen bien a todos, o a la mayoría, o a los sabios, y, entre estos últimos, a todos, o a la mayoría, o a los más conocidos y reputados [...]". Aristóteles, Órganon, 100 a. trad. cast. M. Candel Sanmartín, Madrid, Gredos, 1982, p. 89.

Más adelante señala 10: “[...] En efecto, no toda proposición ni todo problema se ha de considerar dialéctico: pues nadie en su sano juicio propondría lo que para nadie resulta plausible, ni pondría en cuestión lo que es manifiesto para todos o para la mayoría: esto, en efecto, no ofrece dificultad, aquello, en cambio, nadie lo haría suyo.

Una proposición dialéctica es una pregunta plausible, bien para todos, bien para la mayoría, bien para los sabios, y, de entre éstos, bien para todos, bien para la mayoría, bien para los más conocidos, y que no sea paradójica: pues cualquiera haría suyo lo que es plausible para los sabios, siempre que no sea contrario a las opiniones de la mayoría. Son también proposiciones dialécticas las semejantes a las plausibles, y las contrarias a las que parecen plausibles, propuestas en forma contradictoria, y 
Este obra forma parte del acervo de la Biblioteca Jurídica Virtual del Instituto de Investigaciones Jurídicas de la UNAM www.juridicas.unam.mx

https://biblio.juridicas.unam.mx/bjv

\section{En este sentido, se señala que}

la postulación del derecho como ciencia retórica sólo tiene sentido sobre la base [...] de la negación del fundamento metafísico del obrar moral y del derecho, que tienen como consecuencia inmediata la negación de una verdad en el campo de lo jurídico y de la ética. La justicia que así surge no puede se nunca una expresión de nada real, sino más bien de un mero acuerdo de voluntades. ${ }^{36}$

Se niega, por tanto, el concepto de verdad en el derecho, aceptando la idea de justicia, pero sin contenido.

\section{Tesis planteada por Perelman sobre los derechos humanos}

Retomando algunos de los preámbulos expuestos anteriormente, y colocados ya dentro del terreno que a nosotros nos interesa, el de los derechos humanos, tenemos que decir que Perelman rechaza expresamente la posibilidad de un fundamento absoluto para estos derechos, pero también rehúsa — como se ha señalado - aceptar que el positivismo formalista pueda ser capaz de dar una respuesta favorable al tema de la fundamentación de los derechos humanos.

Toda búsqueda de un fundamento — señala Perelman - supone la necesidad de fundamentar; $y$, si esa necesidad se manifiesta a partir de no importa qué, el problema del fundamento no recibirá jamás solución satisfactoria, toda vez que conducirá a una regresión sin fin. Para que la búsqueda de fundamento sea una empresa con sentido, se requiere que se admita la existencia de realidades o principios que sirvan de fundamento a otras cosas, y que son ella mismas incontestables o, por lo menos, incontestadas. Por el contrario, lo que se propone fundamentar debe ser comprensible ya sea jurídica o fácticamente. ${ }^{37}$

todas las opiniones que están de acuerdo con las técnicas conocidas. Pues, si es plausible que el conocimiento de los contrarios sea el mismo, también parecerá plausible que la sensación de los contrarios sea la misma; y que, si existe un único arte de leer y escribir, también existirá un sólo arte de tocar la flauta, mientras que, si existen varios artes de leer y escribir, también existen varios artes de tocar la flauta [...]". Ibidem, pp. 104-106.

36 Serna Bermúdez, P., op. cit., nota 1, pp. 171-172.

37 "Toute recherche d'un fondement suppose le besoin de fonder et, si ce besoin devait se manifester à propos de n'importe quoi, le problème du fondement en recevrait jamais de solution satisfaisante, car il conduirait à una règression sans fin. Pour que la recherche d'un fondement soit une entreprise sensèe, il faut donc qu'on admette l'existence de réalités ou de principes qui servent de 
Este obra forma parte del acervo de la Biblioteca Jurídica Virtual del Instituto de Investigaciones Jurídicas de la UNAM www.juridicas.unam.mx

https://biblio.juridicas.unam.mx/bjv

En este sentido, el pensador belga propone un fundamento suficiente que pueda superar los extremos a los que nos llevan el dogmatismo y el escepticismo filosófico. ${ }^{38}$ Por eso, "la búsqueda de fundamentos suficientes, pero relativos a un espíritu, a una sociedad o a una disciplina determinadas, deviene filosóficamente esencial para todos aquellos quienes, rehusando la evidencia de valor a un criterio absoluto, no pueden sin más, adherirse a un escepticismo negativo y estéril". 39

Como puede observarse, para la elaboración de este fundamento suficiente habría que partir entonces, alejándose primero de las dos posturas que aceptan y niegan la evidencia o verdad en los valores,

en las filosofías clásicas [...] el criterio de la evidencia que concierne a las intuiciones, racionales o sensibles, debe permitir la distinción, en una ontología o en una epistemología, las realidades y los principios que se imponen y que no tienen que ser fundadas en otras cosas; las realidades, las verdades, las normas y los valores que deben encontrar su fundamento en ellas mismas. ${ }^{40}$

Según esto, lo que es evidente no tiene ninguna necesidad de prueba. El fundamento, por tanto, es evidente y absoluto. Pero también nos encontramos con que, en la

concepción empirista del conocimiento, sólo la sensación nos proporciona el fundamento indubitable. Resulta que las normas y los valores que no son dados por la sensación deberían ser fundados sobre cualquier realidad empírica; sin embargo, como no se puede deducir del ser el deber ser, las normas y valores privados de fundamento válido, no serán más que la expresión de emociones objetivas o de mandamientos que adquirieren su prestigio de la fuente que los impone y los sanciona. ${ }^{41}$

fondement à autre chose, et qui soient eux-memes incontestables ou, du moins, incontestés. Par contre, ce que l'on se propose de fonder devrait entre soit contestable, en droit, soit contesté, en fait". Perelman, Ch., "Peut-on fonder les droits de l'homme"?, op. cit., nota 29, p. 67.

38 "Insisto sobre la distinción entre lo incontestable y lo incontestado, contestable y lo contestado, dado que esa ignorancia se encuentra en el origen de confusiones que hacen oscilar la filosofía del absolutismo al escepticismo, dos posiciones que me parecen, por su exageración, igualmente contrarias a los mecanismos efectivos de nuestro pensamiento, que se sitúa, normalmente, entre ambos", ibidem.

39 "La recherche de fondements suffiasants, mais relatifs à un esprit, une société ou une discipline déterminés, devient philosophiquement essentielle pour tous ceux qui, tout en refusant à l'évidence la valeur d'un critère absolu, en peuvent néanmoins se contenter d'un scepticisme négatif et stérile", ibidem, p. 68.

40 Idem.

41 Ibidem, pp. 68-69. Cfr. también, Serna Bermúdez, P., op. cit., nota 1, p. 174. 
Este obra forma parte del acervo de la Biblioteca Jurídica Virtual del Instituto de Investigaciones Jurídicas de la UNAM www.juridicas.unam.mx

https://biblio.juridicas.unam.mx/bjv

Es decir, el poder. ${ }^{42}$

Se observa cómo, en el último de los argumentos expuestos, Perelman objeta igualmente el positivismo jurídico como forma de fundamentar los derechos humanos, al señalar que éste "negó la existencia que no fuera la expresión de la voluntad del soberano". ${ }^{43}$ Dicho positivismo se derrumba ante los abusos del hitlerismo. Se observa, entonces, cómo Perelman pretende alejarse de estos dos extremos, rechazando ambos. Esto lo confirma cuando señala: "este absolutismo ideológico, al que debe conducir la búsqueda de un fundamento absoluto e inmutable, de la misma manera que cuando es un fundamento positivista, me parece inaceptable". ${ }^{44}$ Sin embargo, no cierra la puerta a la posibilidad del fundamento. "Pero esto — continúa diciendo - no significa que la búsqueda de un fundamento no absoluto sea carente de sentido y de alcance". ${ }^{45}$

Perelman recurre como primer paso en la construcción de su propuesta a la aceptación de principios — principios generales del derecho- que nadie tiene el afán de refutar; pero que presentan problemas cuando se trata de convertir esas reglas generales en casos de especie ${ }^{46}$ por la diversidad de interpretaciones que han recibido.

Ante dicha dificultad,

la búsqueda de un fundamento absoluto debe ceder el paso a una dialéctica. $^{47}$ en la que los principios que la elaboren para sistematizar y jerarquizar los derechos del hombre, tal y como los conocemos, sean constantemente confrontados con la experiencia moral, las reacciones de nuestra conciencia. La solución de los problemas suscitados por esta confrontación no será ni evidente ni arbitraria: será (éste es uno de los principales argumentos de la tesis de Perelman) proporcionada gracias a una toma de posición teórica

42 Cfr., ibidem, p. 175. El propio Perelman señala que, "en una visión teocrática de la sociedad, cuando el mandamiento es supuestamente emanado de una fuente perfecta, la norma que establece no puede ser discutida. Si el mandamiento emana de la voluntad general, constituida gracias a un contrato social, la norma que él establece es considerada como obligatoria en virtud del principio pacta sunt servanda. La voluntad del soberano, netamente expresada, dotará a esas normas de un fundamento indiscutible. Veamos como, transfiriendo a la voluntad general las funciones anteriormente cumplimentadas por la voluntad divina (vox populi vox Dei) [...]". Perelman, Ch., "Peut-on fonder les droits de l'homme"?, op. cit., nota 29, p. 69.

43 Idem.

44 Ibidem, p. 70.

45 Idem.

46 Cfr. Ibidem, p. 71.

47 Dialéctica es el método - según Aristóteles - con cuyo auxilio se puede formar toda clase de silogismos sobre todo género de cuestiones, partiendo de proposiciones simplemente probable, y que nos enseñe, cuando sostenemos una discusión, a no adelantar nada que sea contrario a nuestras propias aserciones. Aristóteles, Órganon..., op. cit., p. 89. 
Este obra forma parte del acervo de la Biblioteca Jurídica Virtual del Instituto de Investigaciones Jurídicas de la UNAM www.juridicas.unam.mx

que resultará de una decisión personal, que se presenta por tanto como válida o verdadera para todos los espíritus razonables. ${ }^{48}$ Esta decisión no está en simple conformidad con la evidencia, y no se da por infalible, no corre el riesgo de proporcionar un fundamento a un despotismo ilustrado o instruido, excento de todo control y de toda crítica. Al contrario: las soluciones contingentes y manifiestamente perfectibles presentadas por los filósofos no podrán pretenderse razonables sino dentro de la mesura donde son sometidas a la aprobación del auditorio universal, constituido por el conjunto de hombres normales y competentes para juzgarlo. ${ }^{49}$

Perelman termina su argumentación afirmando que

lo razonable no remite a una razón divina, invariable y perfecta, sino a una situación puramente humana, la adhesión presunta de todos aquellos que son considerados como interlocutores válidos respecto a las cuestiones debatidas. La presunción permite la elaboración de una regla, de una norma, pero que escapa, sin embargo, al control de los hechos: la norma, lo normativo, es inicialmente asociado a lo normal, a lo que es [...]. ${ }^{50}$

El concepto de racionalidad que Perelman sustituyó por el de razonabilidad, y que es el que emplea en su discurso, se elabora, como hemos visto, a partir del "concurso de todos los seres humanos susceptibles de integrase en el auditorio universal y confrontar sus ideas, el conocimiento de sus reacciones afectivas" ${ }^{51}$ De este modo, los derechos humanos sólo serán aquellos a los que razonablemente llegue un auditorio, es decir, el consenso. Esto ayudará, dice Perelman, "al progreso del pensamiento teórico", 52 reconociendo implícitamente la posibilidad de una sucesión progresiva de concepciones más y más razonables; de esta manera, el fundamento propuesto "no será un fundamento absoluto, ni el único fundamento concebible, y que los derechos que permitan justificar no serán definitivos". 53

48 Las cursivas son nuestras.

49 Perelman, Ch., "Peut-on fonder les droits de l'homme"?, op. cit., nota 29, p. 72.

50 Idem.

51 Ibidem, p. 73.

52 Idem.

53 Idem. Las cursivas son nuestras. 
Este obra forma parte del acervo de la Biblioteca Jurídica Virtual del Instituto de Investigaciones Jurídicas de la UNAM www.juridicas.unam.mx

https://biblio.juridicas.unam.mx/bjv

\section{Observaciones a la tesis propuesta por Perelman}

Es claro que algunas de las objeciones que hicimos a la tesis de Bobbio pueden ser aplicadas igualmente a la tesis de Perelman. Veamos cuáles pueden ser.

a) Relativización de los derechos desde lo razonable

Parece que el alejamiento que intenta Perelman, tanto del dogmatismo filosófico como del escepticismo, es legítimo pero, como dice Serna, injustificable. ${ }^{54}$ La expresión que emplea - lo razonable - tiene como objetivo fundamental precisamente ese distanciamiento, en aras de evitar la arbitrariedad en la que pueden incurrir ambos extremos. Sin embargo, habría que decir al respecto que, desde la posición que asume el profesor belga, que es una posición intermedia, dicha arbitrariedad no desaparece del todo. ${ }^{55}$ Hablar de lo razonable en el campo de los derechos humanos es dejar en un hecho real, el consenso, la posibilidad de que el diálogo y la contraposición de argumentos puedan decidir cuáles son derechos humanos y cuáles no. De este modo, sólo el acuerdo al que razonadamente se llegue podrá ser aceptado como instancia última por la que se establezcan o supriman derechos.

Lo anterior tiene un problema de partida: la negación de la verdad como dato objetivo. Si negamos, como lo hace Perelman, la imposibilidad de una verdad dentro de los derechos humanos, hemos de partir exclusivamente de aquello que fácticamente nos presenta la realidad, es decir, del consenso, o sea, de aquello a lo que intersubjetivamente se llegue, subjetivizando y relativizando por tanto estos derechos. Luego entonces, si por fundamento habíamos entendido —en el sentido tradicional de la expresión - aquel dato objetivo que sustenta a los derechos humanos, es claro que la subjetivización planteada por Perelman no encuadra dentro de este sentido de fundamento, a menos que identifique al consenso como un criterio objetivo, cosa que parecería contradictoria.

En último extremo, cualquier edificio de fundamentación que pretendamos construir debe descansar sobre alguna verdad: de lo contrario, los derechos serán siempre una imposición, más o menos solapada, procedente de una

55 Cfr. ibidem, p. 172. 
Este obra forma parte del acervo de la Biblioteca Jurídica Virtual del Instituto de Investigaciones Jurídicas de la UNAM www.juridicas.unam.mx

voluntad que se ha adherido, por fe a determinados postulados, y que utiliza instrumentalmente a la racionalidad. ${ }^{56}$

Parece claro que, desde la óptica en la que Perelman pretende fundamentar los derechos humanos, existe un presupuesto básico, no sujetable al consenso y sin el cual no podría existir el diálogo: el concepto de persona, y, sobre todo, la dignidad de ésta. Es lógico que para que exista un acuerdo deben existir unos hombres (auditorio universal) capaces de racionalmente llegar a un consenso.

Dicho de otro modo, para que pueda existir consenso deben existir unos entes - llamados hombres - dotados de ciertas y determinadas características: la racionalidad, capacidad de lenguaje, etcétera, que les confiere una cierta dignidad y los diferencian de los restantes entes del universo. ${ }^{57}$

\section{b) Razonabilidad vs. objetividad}

Pero hay más, estos "hombres" tienen que mantener entre ellos un punto común de discusión. En el caso de los derechos humanos, será el "argumento suficiente" en favor de ellos. Así, se hace necesario partir, para tal efecto, de un dato precedente: los derechos que le pertenecen a las personas, en definitiva, se requiere tener preliminarmente una concepción antropológica de lo que es la persona y de cuáles son sus derechos. Esto, en mi opinión, nos coloca ante una noción objetiva que, en el discurso, no puede estar supeditada a la arbitrariedad del consenso acordado. De lo contrario, ¿de qué se va a partir?, ¿cuál sería el primer elemento de discusión sin esa concepción de la persona? Por eso, "la idea de consenso no sugiere un valor en sí misma, sino sólo en función de una determinada concepción del hombre" ${ }^{58}$ En definitiva, la respuesta a las anteriores interrogantes parece encontrarse en la idea de dignidad de hombre que, en el supuesto de que fuera aceptada por el consenso planteado por Perelman, ésta no fundamentaría suficiente y satisfactoriamente los derechos humanos. ${ }^{59}$

56 Ibidem, p. 181.

57 Massini Correas, C. I., Los derechos humanos en el pensamiento actual, 2a. ed., Buenos Aires, Abeledo-Perrot, 1994, p. 136.

58 Cfr. Serna Bermúdez, P., op. cit., nota 1, p. 178.

59 Cfr. ibidem, pp. 178-179. 
Este obra forma parte del acervo de la Biblioteca Jurídica Virtual del Instituto de Investigaciones Jurídicas de la UNAM www.juridicas.unam.mx

https://biblio.juridicas.unam.mx/bjv

\section{c) Interrogantes sin respuesta}

Para finalizar, algunas preguntas. Desde la perspectiva de Perelman, es necesario que exista un auditorio universal constituido por "hombres normales y competentes para juzgar". A este argumento valdría preguntarse: ¿cuáles son los criterios con los que se ha de juzgar quiénes son hombres normales y quiénes no?, ¿quiénes realizarían esta selección? Además, ¿existe un punto de referencia a partir del cual estos hombres normales puedan juzgar qué son y qué no son los derechos humanos?

\section{CONCLUSIÓN}

A modo de conclusión, tendríamos que decir que el consenso propuesto por Perelman nos lleva al mismo error que advertíamos en Bobbio: la relativización de los derechos humanos. Desde esta perspectiva relativista,

no es posible otorgar un fundamento sólido a los derechos de las personas, es decir, un fundamento teoréticamente firme, sino que pueda esgrimirse válidamente aun en circunstancias excepcionales o cuando la concreción de los derechos contraríe los intereses inmediatos de quienes deben respetarlos. Y ello es así, porque la relatividad de su fundamento se transfiere, por necesidad lógica, a los derechos fundados; en efecto, es una regla lógica universalmente aceptada que las conclusiones no pueden ser más fuertes que las premisas; así, por ejemplo, de una o varias afirmaciones probables no puede seguirse una afirmación cierta. Del mismo modo, de una afirmación relativa: "los derechos humanos tienen fundamento si y sólo si existe consenso al respecto", sólo podrá seguirse la afirmación siguiente: "tal derecho humano (el derecho a no ser torturado, por ejemplo) estará fundado si y sólo si existe consenso al respecto". Dicho más concretamente, si existe el consenso acerca de que los judíos, los negros, los católicos o los terroristas pueden ser torturados en ciertas circunstancias [...] ellos carecerán - en esas circunstancias - del derecho a no ser torturado. Y carecerán de él toda vez que no existirá el fundamento lógicamente necesario para que este derecho sea tal y pueda, en consecuencia, ser reclamando o exigido. ${ }^{60}$

Habíamos establecido como título del presente artículo la pregunta sobre la posibilidad de que el consenso sirviera para fundamentar los de-

60 Massini Correas, C. I., Los derechos humanos en..., op. cit., pp. 134-135. 
Este obra forma parte del acervo de la Biblioteca Jurídica Virtual del Instituto de Investigaciones Jurídicas de la UNAM www.juridicas.unam.mx

rechos humanos. A la luz de lo que hemos expuesto, parece difícil aceptar dicha postura si, como dice Dworkin, nos queremos tomar en serio los derechos.

\section{BIBLIOGRAFÍA}

"El problema del fundamento de los derechos humanos", Anuario de Derechos Humanos 1, Madrid, 1982.

"Los derechos inherentes a la dignidad de la persona humana", Humana Iura 1, Pamplona, 1991.

"Peut-on fonder les droits de l'homme"? en Droit, morale et Philosophie, 2a ed., París, Librairie Generale de Droit et de Jurisprudence, 1976.

"Presente y porvenir de los derechos humanos", Anuario de Derechos Humanos 1, Madrid, Servicio de Publicaciones de la Universidad Complutense de Madrid, 1982.

"Sobre el puesto de la historia en el concepto de los derechos fundamentales", Anuario de Derechos Humanos 4, Madrid, Servicio de Publicaciones de la Universidad Complutense de Madrid, 1986-87.

"Sul fondamento dei diritti dell'uomo", en Il problema della guerra e le vie della pace, Bologna, Il Mulino, 1979.

AA. VV., Veinte años de evolución de los derechos humanos, México, UNAM, 1974.

BEUCHOT, M., Filosofía y derechos humanos (los derechos humanos y su fundamentación filosófica), México, Siglo XXI, 1993.

BobBIO, N., L'Età dei diritti, trad. cast. R. de Asís Roig, Madrid, Sistema, 1991.

CARPINTERO, F., Derecho y ontología jurídica, Madrid, Actas, 1993.

Derechos humanos. Iuspositivismo y iusnaturalismo, México, UNAM, 1995.

El positivismo jurídico, Madrid, Debate, 1993.

FERnÁNDEZ, E., Teoría de la justicia y derechos humanos, Madrid, Debate, 1991.

Filosofía del derecho y los derechos humanos, Buenos Aires, AbeledoPerrot, 1994.

Guasp Delgado, J., Derecho, Madrid, Hergon, 1971.

HervadA, J., Escritos de derecho natural, 2a. ed., Pamplona, Eunsa, 1993. 
Este obra forma parte del acervo de la Biblioteca Jurídica Virtual del Instituto de Investigaciones Jurídicas de la UNAM www.juridicas.unam.mx

https://biblio.juridicas.unam.mx/bjv

Hoyos Castañeda, I. M., El concepto jurídico de persona, Pamplona, Eunsa, 1989.

Introducción crítica al derecho natural, 7a ed., Pamplona, Eunsa, 1993.

Justice et raison, Bruxelles, Presses Universitaires de Bruxelles, 1963.

La desintegración del pensar jurídico en la Edad Moderna, Buenos Aires, Abeledo-Perrot, 1980.

Lecciones propedeúticas de filosofía del derecho, Pamplona, Eunsa, 1992.

Los derechos fundamentales, 5a ed., Madrid, Tecnos, 1993.

Los derechos humanos en el pensamiento actual, 2a. ed., Buenos Aires, 1994.

MASSINI CORREAS, C. I., El derecho, los derechos humanos y el valor del derecho, Buenos Aires, Abeledo-Perrot, 1987.

NASH, R., "¿Tienen derechos las rocas? Pensamientos sobre la ética del medio ambiente", en M. Mooney y F. Stuber (comp.), Los humanistas y la política, México, FCE, 1984.

Norberto Bobbio: el filósofo y la política, México, FCE, 1996.

PECES BARBA, G., Escritos sobre derechos fundamentales, Madrid, Eudema, 1988.

PERELMAN, CH., Le champ de l'argumentation, Bruxelles, PUB, 1970.

PÉrez Luño, A. E., Derechos humanos, Estado de derecho y Constitución, 4a. ed., Madrid, Tecnos, 1991.

RABOSSI, E., "El fenómeno de los derechos humanos", en Ética, política y derecho, México, UNAM-Siglo XXI, 1991.

SERnA BermúdeZ, P., Positivismo conceptual y fundamentación de los derechos humanos, Pamplona, Eunsa, 1990.

Teoría general del derecho, Madrid, Debate, 1993.

Traitè de l'Argumentation. La Nouvelle rètorique, 2a. ed., Bruxelles, Université de Bruxelles, 1976.

TRUYOL y SERRA, A., Los derechos humanos. Declaraciones y convenios internacionales, 3a. ed., Madrid, Tecnos, 1984.

Una introducción a la ciencia jurídica, Madrid, Civitas, 1988.

Verdoot, A., Naissance et signification del la Déclaration Universelle des Droits de l'Homme, trad. cast., Arzálluz, J., Bilbao, Mensajero, 1969. 


\title{
LA EVOLUCIÓN DEL CONCEPTO DE DERECHOS HUMANOS Y SUS MODERNAS CRÍTICAS
}

Caridad VeLARDE QUEIPO DE LLANO

\begin{abstract}
SUMARIO: I. Origen liberal de los derechos humanos. Relación con la noción de tolerancia. II. Actualidad del modelo liberal de derechos humanos y sus críticas. III. Recuperación de la idea de tolerancia. ¿Una universalidad posible? IV. Bibliografía.
\end{abstract}

A sólo dos años del cincuentenario de la Declaración Universal de los Derechos Humanos proclamada por las Naciones Unidas tras la segunda gran guerra, y dos siglos después de las primeras declaraciones francesa y americana, las perspectivas desde las que cabe estudiar el fenómeno de estos derechos se han multiplicado. Mucha tinta ha corrido al respecto $\mathrm{y}$ no se trata de incrementar gratuitamente la literatura que ya existe, ni de volver a presentar un estado de la cuestión, intento que ha contado ya hasta el momento con muchas y muy buenas aportaciones. En cambio, quizá sea esta una buena ocasión para detenerse a analizar lo que del espíritu que animó a aquellas declaraciones sigue vigente. No deja de ser significativa la evolución del lenguaje de los derechos, no sólo porque cada vez más en documentos de todo tipo se hace referencia a versiones que se alejan del individualismo que originalmente se encontraba en el sustrato de los derechos, sino sobre todo por el cuidado con que se evita añadir el término 'humanos', con toda la carga de significación que esto puede llevar consigo.

Es el nuestro un momento cultural que se gloría de estar poniendo en entredicho las mismas bases en las que se asienta el proyecto ilustrado, a pesar de considerarse su heredero. El acuerdo generalizado que reconocía la legitimidad democrática y la noción de derechos como los pilares sobre los que se asienta la moderna sociedad occidental está siendo sometido a revisión, así como la mentalidad racionalista que los sustenta y la creencia en el progreso indefinido, del cual la versión económica es sólo una de sus facetas. El giro linguístico y las aportaciones de la hermenéutica, 
Este obra forma parte del acervo de la Biblioteca Jurídica Virtual del Instituto de Investigaciones Jurídicas de la UNAM www.juridicas.unam.mx

https://biblio.juridicas.unam.mx/bjv

las tendencias contextualizadoras y las distintas formas de realismo, son algunos de los núcleos de influencia desde los cuales se ha venido minando la confianza en que se haya alcanzado el conocimiento de un modelo de hombre y de sociedad universales en el espacio y en el tiempo.

\section{ORIGEN LIBERAL DE LOS DERECHOS HUMANOS. RELACIÓN} CON LA NOCIÓN DE TOLERANCIA

Los derechos humanos son, como los códigos civiles o la escuela de la exégesis, uno de los productos característicos del pensamiento ilustrado y de la mentalidad liberal en lo que al fenómeno jurídico se refiere. Comprenderlos en toda su extensión exige conocer la incidencia de los planteamientos filosóficos que se encuentran en el origen del liberalismo, así como la relación que necesariamente tiene esta ideología con la noción de Estado. Los derechos humanos son una construcción histórica. ${ }^{1}$ que se sustenta sobre unas determinadas bases filosóficas; ${ }^{2}$ veamos cuáles son los elementos conformadores de aquella noción para poder analizar a continuación lo que de ella queda y hacia dónde se dirigen las críticas en la actualidad.

El fenómeno ilustrado que está en el fondo de los movimientos sociales y políticos del XVIII, es una revolución que afecta al núcleo del pensamiento por lo que genera tendencias en ámbitos diferentes, y propicia asimismo distintas interpretaciones del papel y límites del entendimiento. ${ }^{3}$ Desde un punto de vista político y económico, la distinción entre una Ilustración americana y una continental ha sido ampliamente estudiada, así como su repercusión en las declaraciones de derechos humanos. La primera, guiada por principios individualistas y en la que la clave de determinación de los derechos es la libertad, guardaría sólo un más o menos cercano parentesco con su homónima europea, más predispuesta a ver en los derechos un contenido material, que a considerarlos como simples limitaciones. ${ }^{4}$ En términos económicos, también puede hablarse de diferen-

1 Carpintero, F., Derecho y ontología jurídica, Madrid, 1993, pp. 61 y ss.

2 Cfr. el volumen publicado por la Unesco bajo el título precisamente de Philosophical Foundations of Human Rights. Aquí se sigue la versión castellana de G. Baravalle titulada Los fundamentos filosóficos de los derechos humanos, Barcelona, 1985. Tienen especial interés las páginas a cargo de Ch. Taylor, pp. 52-61.

3 Cfr. Kriele, M., Liberación e ilustración, citada por la versión castellana de C. Gancho, Barcelona, 1982, pp. 17 y ss.

4 Acerca de la tesis ya comunmente aceptada de dos versiones distintas de la Ilustración que 
Este obra forma parte del acervo de la Biblioteca Jurídica Virtual del Instituto de Investigaciones Jurídicas de la UNAM www.juridicas.unam.mx

https://biblio.juridicas.unam.mx/bjv

LA EVOLUCIÓN DEL CONCEPTO DE DERECHOS HUMANOS

cia, en razón de que se dé una mayor o menor libertad a los individuos; o, mejor dicho, en razón de que haya o no una meta común a la que los individuos se tengan que ajustar.

Ahora bien, es posible también establecer entre ambas una distinción según, no ya el contenido de los derechos, sino el método de su obtención, que implica la cuestión de su fundamento. ${ }^{5} \mathrm{Si}$ bien ambas se inspiran en una cierta forma de iusnaturalismo, en el caso de la Declaración francesa se trata de un iusnaturalismo racionalista, ${ }^{6}$ según el cual, la fuerza de la razón es capaz de conocer el mejor derecho posible (podríamos hablar de un iusnaturalismo autónomo con respecto a cualquier instancia externa), en tanto que en el caso americano, se trata de un iusnaturalismo conectado con una norma moral que viene dada y que en último término no se puede independizar del fenómeno religioso. ${ }^{7}$ En tanto que la Declaración francesa es una pretensión abstracta, la americana quiere encontrar el modo de hacer viable la convivencia entre concepciones muy diferentes de la vida buena. La base de este segundo sistema es la tolerancia frente a la pura autonomía continental.

Aunque en la distinción de poderes Locke antecedió a Montesquieu, la asunción francesa de este dogma resultó muy diferente de la anglosajona. En Francia se tradujo en un principio de legalidad que santificaba la

generarán dos formas de entender el liberalismo $c f r$. Negro Pavón, D., Liberalismo y socialismo. La encrucijada intelectual de Stuart Mill, Madrid, 1975. Es interesante la aportación de Hayek, en varios de sus trabajos entre los que podría citarse por ejemplo, The Constitution of Liberty, citada según la versión castellana Los fundamentos de la libertad, Valencia, 1961, tr. de J.V. Torrente. Puede ser útil también consultar el escrito de Gentz, F., "Comparación entre la revolución norteamericana y la revolución francesa”, Cuadernos del pensamiento liberal, núm. 2, marzo de 1986, pp. 55-82.

5 Cfr. la polémica Boutmy-Jellinek, recogida en J. G. Amuchástegui (de.), Orígenes de la Declaración de Derechos del Hombre y del Ciudadano, Madrid, 1984. La discusión se centra en la filiación de la Declaración de Derechos del Hombre y del Ciudadano y sobre si puede atribuirse a influencia americana o, por el contrario, a la ilustración francesa, concretamente a Rousseau. La diferencia entre una y otra concepción es vital porque el punto de partida de la versión de los derechos americana es la idea de libertad individual como contraposición al poder público, que, como consecuencia, debería justificar cada una de esas interferencias en el comportamiento privado. Lo contrario sucede con la versión continental que se funda en una idea fuerte de derechos y precisa la intervención del Estado para reconocerlos y sostenerlos. Otros autores consideran esta tesis demasiado simplista, $c f r$. Peces Barba, "Los derechos del hombre en 1789. Reflexiones en el segundo centenario de la Declaración Francesa”, Anuario de Filosofía del Derecho, VI, 1989, pp. 57-128.

6 Acerca de la distinción entre el iusnaturalismo clásico y iusnaturalismo racionalista, $c f r$. Gil Cremades, J. J., “¿Que es el derecho natural clásico?”, Temis, núm. 23-24, 1968, pp. 51-72; y F. Carpintero, "Los tres iusnaturalismos", Ars Iuris, núm. 12, 1994, pp. 87-106.

7 La obra de Locke ha recibido interpretaciones divergentes pero lo cierto es que el texto del Segundo Tratado del Gobierno Civil es claro al respecto. 
Este obra forma parte del acervo de la Biblioteca Jurídica Virtual del Instituto de Investigaciones Jurídicas de la UNAM www.juridicas.unam.mx

https://biblio.juridicas.unam.mx/bjv

norma emanada del legislador y pretendía independizarla radicalmente de cualquier posible injerencia por parte del Poder Judicial. Parece como si lo que se tratara de proteger fuera la ley misma, buscando en su creación y aplicación un principio racional y científico que ningún criterio político más o menos personalizado pudiera turbar. En el ámbito anglosajón no es tanto esto lo que se proteje como la libertad individual frente a la presumible tendencia a la tiranía del poder público o de otras fuerzas sociales. Por otra parte, la concepción americana determina la justicia de una ley atendiendo a su elaboración democrática como un requisito formal, pero también según el respeto y coherencia con lo establecido en la Constitución. En cambio, la francesa considera justa cualquier norma democráticamente elaborada. Como tal, el Poder Legislativo es absoluto y no hay norma por encima de él que pueda limitar sus competencias, lo que es lo mismo que decir que no tiene límite externo.

Ahora bien, las declaraciones de derechos en sus tres versiones más representativas comparten un elemento común que es su cáracter negativo, de oposición a un peligro encarnado en una forma de poder ilimitado. El concepto mismo exige una noción de Estado con su consiguiente monopolio de la fuerza y, si se trata de darle alcance internacional, una organización supraestatal. El ideal político ilustrado y en general liberal, tiene como fin último el logro de la paz con la consiguiente estabilidad social. Esto exige que el poder esté centralizado, sea cual sea la extensión de ese poder que el Estado ejerza efectivamente. En el fondo es lo mismo que decir que lo público queda reducido a lo estatal. No se reconocen otras esferas de desarrollo o ejercicio de lo público más allá del poder político, o que éste de algún modo no cree, controle o permita. Estas premisas obligan a la teoría política liberal a concentrar sus esfuerzos en el control de la actividad del Estado. No se trata de propugnar exclusivamente el sistema democrático, o de considerar que la democracia sea exclusivamente un participar de algún modo en la toma de decisiones. A esto no se puede reducir la libertad política. Ya lo pusieron de manifiesto Condorcet en su discurso Sobre la libertad de los antiguos comparada con la libertad de los modernos ${ }^{8}$ y Tocqueville en La democracia en América ${ }^{9}$ al hablar de la tiranía de las mayorías. Dicho de otro modo, la simple participación política no supone libertad sino que lo que realmente genera

8 Publicado en castellano en los Cuadernos del Pensamiento Liberal, núm. 7, junio de 1987, pp. 67-78.

9 Cfr. Tocqueville, A. de, De la Democratie en Amerique, París, 1961, pp. 261 y ss. 
Este obra forma parte del acervo de la Biblioteca Jurídica Virtual del Instituto de Investigaciones Jurídicas de la UNAM www.juridicas.unam.mx

https://biblio.juridicas.unam.mx/bjv

libertad en los individuos es que puedan moverse en libertad dentro de la sociedad, y que se vean respetados sus derechos.

Si la idea liberal de Estado y sociedad se asienta sobre dos pilares básicos, las libertades políticas y los derechos humanos, ${ }^{10}$ esos pilares a su vez podrían resumirse en dos principios siempre en equilibrio inestable: libertad e igualdad. Pues bien, las críticas más importantes de que está siendo objeto el liberalismo en este momento se refieren precisamente a ambos, y en buena medida tienden a poner de manifiesto la imposibilidad de hacerlos conciliar en los temas realmente importantes. Un primer nivel de críticas con la consiguiente necesidad de reexplicación por parte de la ideología se refiere a la libertad y a la tolerancia, en tanto que un segundo nivel cuestiona no ya el fundamento o el contenido sino la misma noción de derechos humanos.

Desde el punto de vista de la ciencia jurídica, su carácter definidor es el de tratarse de una noción que se funda en una visión personalista del derecho en lugar de realista. El centro de atención no es la cosa que se debe sino la persona a la que le es debida, o, mejor aún, las vías de que dispone para la reclamación de esa deuda. Baste ver cómo el acento se pone no en los bienes que se protegen sino en la dignidad del individuo, que, por otra parte, no siempre se trata de algo reconocido, sino otorgado. Pero la base en la que se asientan no es sólo personalista sino individualista, en el sentido de que los derechos protegen intereses individuales que, por definición, entran en conflicto con los intereses de otros. Es precisamente el entenderlo en clave de conflicto lo que le da ese carácter abstracto. Tener un derecho no confiere un poder inmediato sobre una cosa, sino que constituye exclusivamente una facultad de reclamación que puede, como se ha dicho, entrar en conflicto con otras. Así, es posible hablar de que el derecho a la vida tenga que ceder ante el derecho de libertad, o viceversa. Precisamente ese carácter abstracto es el que posibilita, e incluso propicia las declaraciones.

Ese subjetivismo tiene una base política en el individualismo y el contractualismo liberales. Con orígenes nominalistas y sustentado en una tesis social contractualista, su incidencia aparece de modo claro en el plano económico, pero también en un plano más general de teoría de los derechos, puesto que implican una postura de los individuos con respecto a

10 Cfr. Habermas, J., "Human Rights and Popular Sovereignty: The Liberal and Republican Versions”, Ratio Iuris, vol. 7, núm. 1, March, 1994, pp. 1-13. 
Este obra forma parte del acervo de la Biblioteca Jurídica Virtual del Instituto de Investigaciones Jurídicas de la UNAM www.juridicas.unam.mx

la organización estatal. Los derechos son poderes de los individuos frente al poder soberano del gobernante. Esto tiene consecuencias, como digo, no sólo económicas, sino de una amplitud mucho mayor, puesto que el liberalismo considera al individuo como un todo tanto frente al gobernante como frente al conjunto de la sociedad que, al fin y al cabo, no es más que la suma de otros individuos como él. Así tiene sentido entender los derechos en clave dialéctica, por oposición a los derechos de otros. Pero no hay que olvidar que, paradójicamente, el individualismo guarda relación directa en sus orígenes con el universalismo que es propio del modo de pensamiento racionalista ilustrado.

En cualquier caso parece que una de las consecuencias comunes a todo el empeño racionalizador de la Ilustración es el tratar de poner por escrito la relación de características del individuo humano que han de ser respetadas por todos los demás. De aquí se deriva la tendencia universalista en lo que al derecho se refiere a la que se ha aludido. Con palabras de Locke:

Desde este punto de vista, todo hombre tiene un derecho a castigar al ofensor y ser ejecutor de la ley de la naturaleza. No dudo que esta parecerá doctrina muy extraña a algunos, pero antes de que la condenen me gustaría que me contestasen por qué derecho cualquier rey o estado pueden condenar a muerte o castigar a un extraño por cualquier crimen cometido en sus paises. ${ }^{11}$

Desde el punto de vista del pensamiento político y jurídico continental, probablemente la primera quiebra del racionalismo ilustrado (cuya traducción jurídica fuera aun en mayor medida que las declaraciones de derechos el esfuerzo codificador que entre otras cosas supone el refrendo del monopolio absoluto de lo jurídico por parte del Estado) vino dada por la oposición de la escuela historicista; frente a la Ilustración del derecho natural racional, que cree haber encontrado la clave para construir el sistema jurídico perfecto, se alza el pensamiento de los que, por el contrario, mantienen la inexistencia de ese derecho abstracto, así como la necesidad de acomodar el contenido de las normas al "espíritu del pueblo".

El liberalismo, en cambio, tiene vocación universal; no se considera a sí mismo un producto cultural, sino la solución a los problemas de dife-

11 Locke, J., "The Second Treatise of Government", Two Treatises of Government, Cambridge, 1988 , p. 272. 
Este obra forma parte del acervo de la Biblioteca Jurídica Virtual del Instituto de Investigaciones Jurídicas de la UNAM www.juridicas.unam.mx

https://biblio.juridicas.unam.mx/bjv

rencias culturales y olvida que en sí mismo también es cultura. La cristalización del liberalismo sobre el papel es abstracta y por tanto irreal, pero sus frutos en la práctica son indudablemente culturales. ${ }^{12}$ Tanto en el nivel político como en el de los derechos el factor fundante del liberalismo, su presunta neutralidad, constituye un espejismo. La propuesta liberal de ofrecer un marco de actuación dentro del cual quepan todas las culturas y todos los planteamientos exige en el fondo pagar un alto tributo pues es a costa de que la organización social no tenga ninguna cultura ni ningún planteamiento. Aparentemente es inocente, pero en la práctica es reductor.

Es muy interesante la percepción de cómo en la historia del pensamiento un objetivismo racionalista, generado en la exigencia de tolerancia, da paso a un escepticismo primero y a un relativismo después. ${ }^{13}$ Es preciso, sin embargo, tener en cuenta que con frecuencia se utilizan como intercambiables nociones que, en realidad, no deberían aplicarse a los mismos fenómenos. Así, por ejemplo, el binomio tolerancia-neutralidad está constituido por conceptos políticos, en tanto que los que constituyen el de objetivismo-relativismo son conceptos éticos. La primera y la segunda parte de ambos binomios se corresponden entre sí, aunque la neutralidad tiene dos lecturas: una se correspondería con el relativismo total, en tanto que la otra se limita a mantener la separación entre moral pública y moral privada. El principal peligro del mundo liberal es el de quedar convertido en una abstracción a pesar de sus orígenes prácticos. No importaría tanto si no fuera por sus promesas y no sirve como justificación apelar a una neutralidad de lo público que no se adecua con la realidad.

\section{ACTUALIDAD DEL MODELO LIBERAL DE DERECHOS HUMANOS Y SUS CRÍTICAS}

Apelar a una noción de derechos humanos implica optar por uno de los siguientes métodos: seguir la vía del consenso, partir de unos bienes humanos básicos o bien, por último, imponer una determinada concepción en ámbitos distintos de aquél en el que se tiene legitimidad. En cuanto a la primera posibilidad, en las modernas sociedades occientales lo que parecía posible está empezando a no serlo precisamente por el creciente

12 Cfr. Arechederra, L., "Revolución, tecnocracia y demagogia", Persona y Derecho, núm. 26, 1992, pp. 29-50.

13 Sobre el paso del objetivismo racionalista al relativismo, $c f r$. Arregui, J.V., y C. Rodríguez Lluesma, Inventar la sexualidad, Madrid, 1995, pp. 104 y ss. 
Este obra forma parte del acervo de la Biblioteca Jurídica Virtual del Instituto de Investigaciones Jurídicas de la UNAM www.juridicas.unam.mx

https://biblio.juridicas.unam.mx/bjv

fenómeno multiculturalista. La tercera tampoco parece aceptable. La segunda, en cambio, ha de ser razonada o rechazada. Cabe desarrollarla según los planteamientos de un racionalismo abstracto o siguiendo unas pautas de caracter realista que, a su vez, pueden basarse en criterios consensualistas, objetivistas. Constituye, por otra parte, probablemente la única posibilidad de intentar escapar al escepticismo de este fin de siglo. ${ }^{14}$

\section{Problemas que se plantean y situación actual}

Los motivos por los que el lenguaje de los derechos humanos se ha visto cuestionado son diversos: para algunos es excesivamente pretencioso y supone una injerencia en asuntos en los que quien habla carece de autoridad. Para otros es más sencillo: el contenido de los derechos varía a tenor de las culturas o las circunstancias históricas. Los argumentos pertenecen, como es obvio a dos niveles diferentes: político el primero, ético el segundo. Mientras a uno le preocupa la legitimidad y la autoridad de la que emanan las normas jurídicas, otro pone en duda la posibilidad de asentarlas sobre fundamentos éticos comunes u objetivos (aunque, esas dos nociones "común" y "objetivo" no son en realidad intercambiables).

El iusnaturalismo racionalista que amparaba las declaraciones de derechos se ha desintegrado. Los que hablan de derechos tratan de hacerlo de un modo contextualizado: referidos a las Constituciones de sus respectivos países o a una tradición cultural determinada. Desde el punto de vista de la teoría del derecho se aduce que la apelación a unos presuntos derechos humanos carece propiamente de carácter jurídico; de ahí la distinción anglosajona, que tan contradictoria suena a oídos continentales, ${ }^{15}$ entre derechos legales y derechos morales reduciendo los primeros a la consideración de derechos subjetivos. ${ }^{16}$ Sólo tienen sentido entendidos como facultades. Alguien tiene un derecho si tiene una posibilidad real de hacerlo valer, de otro modo no se tratará de derecho sino de una ilusión; todo lo más de un derecho moral. Plantear objeciones a este punto de vista exigiría partir de una noción realista y constituiría en consecuencia una enmienda a la totalidad del sistema. A pesar de ello es ésta una de las vías que está siguiendo una amplia línea de pensamiento que

14 En este punto $c f r$. Farrara, A., "Universalism: procedural, contextualist and prudential", en Rasmussen (ed.), Communitarianism vs. Universalism, Cambridge, London, 1990, pp. 11-37.

15 Ollero, A., Positivismo conceptual y derechos humanos, Madrid, 1986.

16 Cfr. Taylor, Ch., "Los fundamentos filosóficos de los derechos humanos. Complemento a la relación del profesor Mathieu”, en AA. VV., Los fundamentos filosóficos..., p. 52. 
Este obra forma parte del acervo de la Biblioteca Jurídica Virtual del Instituto de Investigaciones Jurídicas de la UNAM www.juridicas.unam.mx

https://biblio.juridicas.unam.mx/bjv

trata de recuperar una visión de los derechos en clave de protección de bienes sociales en lugar de intereses individuales. ${ }^{17}$

Una crítica habitual en los últimos años ha sido la que se opone al individualismo liberal, entendido como una forma de egoísmo, poniendo el acento en lo social, ahora desde un punto de vista económico. Dentro de las mismas filas liberales se han alzado voces cuestionando la noción de derechos entendidos exclusivamente como libertades negativas y exigiendo un contenido positivo de los mismos. ${ }^{18}$ Desde instancias más cercanas al republicanismo otros han apelado a la noción de sociedad civil manteniendo la existencia de una obligación por parte de la sociedad de salir al paso de las necesidades de los individuos, obligación que, sin embargo, no necesariamente es responsabilidad directa de los poderes públicos, aunque éstos deberán asumirla de modo subsidiario. Ahora bien, la propuesta de alternativas al individualismo va más allá del terreno estrictamente económico. Es posible trascender la visión de los derechos como exigencias individuales y a determinar desde el punto de vista del interés individual, y esto tiene mucho que ver con una crítica fuerte al universalismo racionalista.

Por último, merece atención la nueva versión del pragmatismo que ha resurgido con fuerza renovada en nuestros días. Rorty, reconocido como uno de sus máximos representantes, se considera a sí mismo liberal, al tiempo que propone un ideal de solidaridad social; pero no le preocupa que ese ideal responda a nada real mientras funcione. La política — dice- sigue un camino distinto del de la filosofía, y las razones por las que se actúa no deben categorizarse como fundamento. Pretende, paradójicamente, una forma de universalismo que excluye intentos fundantes del tipo que sean.

\section{Continuadores de la tradición universalista}

Aunque el universalismo racionalista inicial pertenece a la historia, hoy perviven formas de universalismo de distinto signo y con diferente fortuna. ${ }^{19}$ La determinación de lo que debe entenderse por universalismo

17 Cfr. Raz, J., "Rights and Politics", Indiana Law Journal, núm. 71, 1995, pp. 27-44.

18 Cfr. Waldron, J., "Liberal Rights: Two Sides of the Coin", en Liberal Rights. Collected Papers 1981-1991, New York ,1993, pp. 1-34.

19 Muestra de un universalismo actual es el artículo de Bayefsky, A., "Cultural Sovereignty, Relativism and International Human Rights: New Excuses for Old Strategies", Ratio Iuris, vol. 9. núm. 1, March, 1996. 
Este obra forma parte del acervo de la Biblioteca Jurídica Virtual del Instituto de Investigaciones Jurídicas de la UNAM www.juridicas.unam.mx

https://biblio.juridicas.unam.mx/bjv

no es tarea fácil, sobre todo porque este término puede adquirir su significado en niveles de conocimiento distintos y oponerse a términos que, a su vez, son contradictorios entre sí. Así, universalismo puede oponerse a relativismo, con lo que podría identificarse con alguna forma de objetivismo ético. ${ }^{20}$ Pero puede también oponerse a realismo, lo que le haría significar una forma de abstraccionismo racionalista. Por otra parte, desde un punto de vista puramente pragmático, universalismo puede significar la necesidad de encontrar cauces de actuación que hagan viable la vida política; esto es lo que Rorty, que no es universalista en los sentidos anteriores, defendería.

En este lugar se tendrán en cuenta fundamentalmente las dos últimas formas, que se combinan en un universalismo entendido en un sentido racionalista y al mismo tiempo pragmático, como el intento de construcción de un universo moral en el que una noción como la de los derechos encuentre justificación. En este sentido, el universalismo ha sido representado en estos últimos años fundamentalmente por autores que mantienen lo que se ha dado en llamar un constructivismo ético ${ }^{21}$ como Nagel $^{22}$ o Gewirth, ${ }^{23}$ que siguen de cerca las tesis de Rawls. No proponen tanto la existencia de derechos universales, como la construcción de un sistema universal de derechos. ${ }^{24}$ Lo que a su entender no significa que se trate de un sistema arbitrario sino perfectamente justificable por su deducción a partir de unos presupuestos conceptuales, así como la aceptación de unas bases sociales y funcionales que vienen dadas.

El intento de Rawls y su escuela se caracteriza por un individualismo que otros, entre ellos Habermas, han tratado de corregir. Este autor con su pragmática universal pretende encontrar un sistema universal que no sea ya consecuencia de una actividad individual, sino de un proceso comunicativo, de una actividad dialogal. Intenta por esa vía superar el individualismo de Rawls, pero sin anclarse en el caos relativista al que puede conducir una apelación descontrolada a la hermenéutica.

20 En este sentido, universalismo puede asociarse tanto a una visión positivista del derecho como a un iusnaturalismo.

$21 C f r$. sobre este punto el excelente análisis de Serna, P., Positivismo conceptual y fundamentación de los derechos humanos, Pamplona, 1990, pp. 227 y ss.

22 Cfr. The View from Nowhere, Oxford, 1986 o Equality and Partiality, Oxford, 1991.

23 Cfr. Reason and Morality, Chicago, 1978, The Community of Rights, Chicago, 1996.

24 Acerca de las referencias habermasianas de estos intentos cfr. McCarthy T., Ideales e ilusiones, Madrid, 1992, p. 21; tr. de A. Rivao. 
Este obra forma parte del acervo de la Biblioteca Jurídica Virtual del Instituto de Investigaciones Jurídicas de la UNAM www.juridicas.unam.mx

https://biblio.juridicas.unam.mx/bjv

No obstante, es preciso hacer notar que algunos confunden este debate con otro referido a la posibilidad de establecer la existencia de derechos absolutos, lo que no es lo mismo que universales. Según ese esquema, la cuestión se reduciría a si hay algún derecho que todas las personas, hombres o mujeres, tengan siempre, en cualquier momento de la historia o de su propia biografía, y sean cuales fueren sus circunstancias personales. ${ }^{25}$ Así dicho, la respuesta se hace difícil y pone sobre el tapete la necesidad de determinar cuál sea la naturaleza de los derechos antes de pasar a hablar sobre su contenido. ${ }^{26}$

\section{El universalismo neopragmatista}

En los últimos años la tradición pragmatista se ha visto renovada e implementada por la obra de autores como Rorty o Bernstein, cuyos escritos guardan una indudable relación con los de sus antecesores del pragmatismo clásico aunque recogen necesariamente las aportaciones de la filosofía de la última mitad del siglo. ${ }^{27}$

Aunque el pragmatismo sea habitualmente conocido, desde sus orígenes, como una escuela de pensamiento propia de América del Norte, ${ }^{28}$ no por ello debe considerarse que no tiene interés en el continente por partir y desarrollarse según premisas y tradiciones diferentes. Su importancia radica principalmente en que constituye una de las versiones (y no la menos coherente) del procedimentalismo ético. Su relación, tanto con la filosofía del lenguaje como con la ética utilitarista, lo dota de una mayor proyección de la que a primera vista se puede

25 Cfr. AA. VV., On Human Rights, S. Shute y S. Hurley eds., New York, 1993.

26 Gewirht, "Are There Any Absolute Rights?, Waldron Therories of Rights, Oxford, 1984, pp. 91-109.

27 Resulta sorprendente cómo una filosofía que había ido perdiendo fuerza a lo largo del siglo, ha sobrevivido a las corrientes positivista, fenomenológica, analítica y deconstructivista. Lo que trae al pragmatismo de vuelta, según Goodman, es la percepción de una convergencia profunda en la filosofía del siglo veinte en la que coinciden los pragmatistas clásicos James, Peirce y Dewey con filósofos europeos como Heidegger y Wittgenstein, en cuyas obras emergen nuevos modos de pensar sobre problemas filosóficos en los que comparecen la 'práctica' y lo 'humano'. Cfr. Goodman, R., "Introducción”, Pragmatism. A Contemporary Reader, New York, 1995, pp. 1 y 2.

28 Esto es así entendido de forma habitual, y Peirce, Dwey y James son considerados como los representantes, no solamente del pragmatismo, sino también, de modo genérico, del pensamiento norteamericano. Sobre esta corriente cfr. Gunn, G., Thinking Across the American Grain. Ideology, Intellect, and the New Pragmatism, Chicago, 1992, Bernstein, R., Beyond Objectivism and Relativism. Science, Hermeneutics and Praxis, Philadelphia, 1983; así como del mismo autor The New Constellation. The Ethical-Political Horizons of Modernity-Postmodernity, Cambridge, Massachusetts, 1991. 
Este obra forma parte del acervo de la Biblioteca Jurídica Virtual del Instituto de Investigaciones Jurídicas de la UNAM www.juridicas.unam.mx

https://biblio.juridicas.unam.mx/bjv

percibir. Además, no cabe duda que entre nosotros está comenzando a ser objeto de merecida atención. ${ }^{29}$

Por otra parte, si bien es cierto que se trata de una problemática ética y de filosofía del lenguaje, también es más que evidente la relación de ambas formas de conocimiento con la filosofía jurídica. En cuanto que filosofía del lenguaje, la relación es clara en un momento en el que el pensamiento sobre el derecho ha adoptado el lenguaje como su objeto central de estudio. Pero además, la ética, como diría Nietzcsche, es el banco de pruebas de la filosofía, allí donde se descubren las más ocultas intenciones, y esto afecta a la filosofía jurídica. Hace ya tiempo que se abandonó por imposible el empeño de convertir la iusfilosofía en una ciencia neutra, en una suerte de técnica que garantizara al menos la igualdad y la seguridad. En este sentido, cualquier nueva propuesta ética ha de ser reconocida como materia propia por la filosofía jurídica.

La clave de la posmodernidad es la ironía, la pérdida de la inocencia. ${ }^{30}$ Se persiguen los ideales sabiendo que no se han de alcanzar, y por eso se habla de ellos con una cierta dosis de cinismo. Todo ha sido ya intentado y nada ha funcionado por completo. Proponer una solución sin tener esto en cuenta es una ingenuidad, y la ingenuidad es el único pecado que lo posmoderno no tolera. La posmodernidad no es exactamente una interpretación de la historia sino lo que sucede a la historia misma. No se puede decir que su objeto sea la historia ni que considere al individuo como un ser histórico, y sin embargo, está claro que su aportación se refiere fundamentalmente al tiempo. Es una forma de ver la relación hombre-tiempo que pretende no contar con ella. Es cualquier cosa menos una teoría sobre la historia. En esta lógica no tiene sentido apelar a la variabilidad histórica de la conducta ética, ni siquiera a la idea de tradición. Todos esos conceptos, así como sus implicaciones temporales, dejan de tener sentido desde el momento en que la sucesión histórica no existe. Lo mismo habría que decir de la implicación espacio-temporal de la hermenéutica.

El pragmatismo es una de las perspectivas desde la que se pueden poner de manifiesto al mismo tiempo las insuficiencias del proyecto ilustra-

29 Ciertamente, ha sido más tratado en el terreno de la ética que en el de la Filosofía del derecho propiamente. Muestra de ese interés es Rubio Carracedo, J., "El ethos posmoderno", Philosophica Malacitana, suplemento núm. 1, con el título El giro posmoderno, pp. 175-194. En el campo de la lógica y por su relación con la filosofía analítica lo han tratado, entre otros, Nubiola, J., La renovación pragmatista de la filosofía analítica, Pamplona, 1994.

30 Cfr. Klappenbach, A., Etica y posmodernidad, Alcalá de Henares, 1990, p. 18. 
Este obra forma parte del acervo de la Biblioteca Jurídica Virtual del Instituto de Investigaciones Jurídicas de la UNAM www.juridicas.unam.mx

do y la pervivencia de su propuesta. Si bien perdura el deseo de construir una sociedad en la que los hombres puedan convivir en paz unos con otros, hacerlo tomando como premisa un modelo de hombre que no es real no conduce a ningún lugar; no dejaremos de movernos en el terreno de la utopía. Estudiar el pragmatismo conduce, por lo mismo, a poner de manifiesto las contradicciones internas de la tradición cultural a la que pertenece.

En cuanto a la noción de derechos humanos que el pragmatismo comporta, ésta se justifica por su eficacia y se asienta sobre los caracteres negativos de no universalidad y ausencia de contenido objetivo. La tesis de Rorty tiene su base en una negación de la razonabilidad humana y, en consecuencia, de los comportamientos humanos. Detrás de nuestros parámetros morales de conducta no hay pautas guiadas por razonamientos, sino principios culturalmente asumidos. ${ }^{31}$ Se caracteriza a sí mismo como filosófo posfilosófico, que ha dejado atrás la etapa de la filosofía. Al mismo tiempo es liberal porque establece una rígida distinción entre lo público y lo privado. La filosofía, como la poesía, pertenece al terreno de lo privado, y no puede pensarse que puedan servir para construir con ellas la esfera de lo público.

Valga como ejemplo el conocido fragmento de La filosofía y espejo de la naturaleza, en donde expone y hace suya la tesis Quine-Seller:

La verdad y el conocimiento sólo pueden juzgarse por los parámetros de los investigadores de nuestro propio tiempo.[...] Es sencillamente decir que nada vale como justificación excepto en referencia a lo que ya aceptamos y que no hay forma de salir fuera de las propias creencias o lenguaje para de esta forma encontrar otra prueba que no sea la coherencia. ${ }^{32}$

Probablemente la gran aportación de Rorty sea su pretensión de separar política y filosofía en beneficio de la primera. Los parámetros culturales no pueden juzgarse de forma externa, descontextualizada. No hay más criterio que la coherencia interna de los planteamientos. Ahora bien, si ni las culturas ni los criterios en ellas generados pueden ser juzgados de forma externa, las mismas tesis de Rorty resultan contradictorias, porque constituyen una toma de postura situándose en un sistema que se caracteriza por tendencias universalistas de diverso signo y que porta desde su 
Este obra forma parte del acervo de la Biblioteca Jurídica Virtual del Instituto de Investigaciones Jurídicas de la UNAM www.juridicas.unam.mx

https://biblio.juridicas.unam.mx/bjv

mismo origen la pretensión de haber logrado el criterio de racionalidad. Paradójicamente, aunque él sienta la base de que las culturas no pueden ser juzgadas de modo externo sino conforme a su propia coherencia interna cae, con respecto a la cultura occidental, en el mismo vicio que critica. $^{33}$

Como se ha dicho, Rorty dice ser un liberal: considera que la moral occidental es superior a la de otras culturas, pero que debemos abandonar el empeño de la modernidad de establecer esa superioridad con parámetros racionales; dicho de otro modo, hay que renunciar a buscar un fundamento para la moral occidental. Es preciso no apelar a parámetros transculturales en esa defensa. Es fácil ver la contradicción en los términos que se aloja en esta expresión, ya que si algo es mejor debe haber algún parámetro que lo determine. Si el único criterio es la coherencia interna de los sistemas, entonces en principio no debiera hablarse en términos comparativos; no tiene lugar decir que un sistema es mejor que otro, ni siquiera en razón de sus resultados prácticos. En realidad, no hace otra cosa que seguir las tesis liberales cuando hace afirmaciones como la siguiente:

Thomas Jefferson estableció el tono de la política liberal americana cuando dijo: "a mí no me causa ningún daño que mi vecino diga que hay veinte dioses o que no hay ninguno". Su ejemplo me ayudó a hacer respetable la idea de que la política puede estar separada de las creencias en cuestiones de importancia, que las creencias compartidas por los ciudadanos en estas materias no son esenciales en una sociedad democrática. ${ }^{34}$

Pero las lleva al extremo al sostener que una tesis pragmática que se deriva de lo dicho por Jefferson es que

Cuando el individuo descubre en sí mismo creencias que son relevantes en la esfera política pero que no se pueden defender sobre la base de creencias compartidas por el resto de los ciudadanos, tiene que renunciar a su conciencia por el beneficio público. ${ }^{35}$

33 Como dice McCarthy: "El irónico resultado es que un proyecto diseñado para una franca autoaceptación de nuestra cultura a través de la curación de sus enfermedades filosóficas se ha metamorfoseado en un revisionismo deflacionista apoyado básicamente por argumentos filosóficos". McCarthy, Ideales e ilusiones, p. 26.

34 Rorty, Objectivity, Relativism and Truth, New York, 1991, p. 175.

35 Idem. 
Este obra forma parte del acervo de la Biblioteca Jurídica Virtual del Instituto de Investigaciones Jurídicas de la UNAM www.juridicas.unam.mx

https://biblio.juridicas.unam.mx/bjv

Da la impresión de que confunde los términos, porque una cosa es que el acto de fe no sea cuestión de la autoridad pública, y otra bien distinta que la actuación del poder público pueda ser neutral para lo cual los valores por los que se rige la actuación pública (que no pueden no existir) tendrían que ser absolutamente relativos y sin ninguna clase de fundamento. ${ }^{36}$

De todo lo dicho se deduce que la tesis central de Rorty puede reducirse a dos cuestiones diferentes: en primer lugar, la imposibilidad de fundamentar la moral, unida a un necesario contextualismo y la improcedencia de juzgar de forma externa cualquier sistema. En segundo término, su propia propuesta acerca de la sociedad liberal, que no pretende ser una propuesta justificada sino basada en consideraciones prácticas y no de principio.

En cuanto a los derechos se refiere, no construye una teora de los mismos, ni pretende analizar si su naturaleza es moral o jurídica. Sin embargo, su interés es grande porque la suya es, al menos aparentemente, una crítica a la racionalidad universalista de la modernidad, que es precisamente la que está detrás de un intento de construcción de una política, además de una moral de derechos. En consecuencia, no interesa tanto por sus tesis acerca de los derechos humanos cuanto porque la lógica de su teoría no admite un lenguaje universal acerca de los derechos, al menos no un lenguaje racional, aunque sí uno sentimental fundado en la solidaridad. Lo que dice el neopragmatismo de Rorty en este punto es que no tiene ninguna utilidad práctica plantearse el fundamento de los llamados derechos humanos. A lo único que conduce es a consumir tiempo y energías. No tiene sentido plantearse si en realidad existe algo objetivo que debería inculcarse, fomentarse,... sea cual sea el momento cultural o histórico del que se parta.

La aportación de Rabossi de que el fundacionalismo en los derechos humanos está pasado de moda, me parece verdadera e importante, y será el tema principal que toque en esta conferencia. Yo incrementaré y defenderé esa afirmación de Rabossi de que la cuestión de si los seres humanos tienen realmente los derechos enumerados en la Declaración de Helsinki no merece la pena ser tratada. En particular, defenderé que nada relevante para la

36 No pienso que se pueda mantener en este punto la relación directa de la que habla Rorty en ibidem, p. 177 y la obra de Rawls. Cfr. Mulhall S., S., y Swift, A., Liberal and Communitarians, Oxford, 1992, pp. 232 y ss. 
Este obra forma parte del acervo de la Biblioteca Jurídica Virtual del Instituto de Investigaciones Jurídicas de la UNAM www.juridicas.unam.mx

https://biblio.juridicas.unam.mx/bjv

elección moral separa a los seres humanos de los animales excepto factores históricamente contingentes del mundo, factores culturales. ${ }^{37}$

La idea es proclamar un pragmatismo absoluto sobre la base de que no hay razones para hacer lo que hacemos. La pregunta tiene que dejar de ser ¿qué es el hombre?, con su pretensión de racionalidad, para transformarse en la esteticista ¿qué mundo queremos legar a nuestros nietos? ?3 $^{38}$ En realidad, confiesa, el único verdadero argumento para erradicar el fundacionalismo es que nos quita demasiado tiempo sin conducir a nada, por lo que podría decirse que es un criterio de eficiencia. La preocupación por los otros, que Rorty considera como algo positivo, no debe tratar de operar por una via racional, ni debe buscar una "comunidad global" a través de la universalización de los presuntos "derechos humanos". En realidad, la única solución para aunar sentimientos y hacer posible la convivencia tendría mucho más que ver con la educación que con la imposición.

Las críticas a Rorty no se han hecho esperar desde puntos de vista muy diferentes. Muchos ponen en duda que su argumentación sea coherente con las tesis liberales, siendo así que ése es uno de los puntos en los que él pone un mayor empeño. Desde las mismas filas del neopragmatismo, Bernstein le ha hecho objeto de comentarios no precisamente positivos. ${ }^{39}$ A pesar de todo ello, indudablemente tiene el mérito de haber abierto un debate y de haber puesto sobre el tapete los puntos centrales de la discusión, aunque no puede decirse que sus conclusiones lo hayan cerrado en absoluto.

\section{La crítica comunitarista}

Como es sabido, el comunitarismo no es propiamente una corriente de pensamiento, sino que se aplica a autores muy diferentes cuyo nexo de unión viene constituido por un factor negativo como es la crítica del liberalismo, y en el que el factor positivo es tan difuso como la noción de "comunidad". ${ }^{40}$ Eso explica que en ocasiones se acoja bajo el mismo tér-

37 Rorty, R., "Human Rights. Rationality and Sentimentality”, en S. Shute y S. Hurley (eds.), On Human Rights, New York, 1993, pp. 111-134.

38 Ibidem, p. 122.

39 Cfr. Bernstein, R., "One Step Forward, Two Steps Backward", recogido en The New Constellation, Cambridge, Mass., 1992, pp. 230-257.

40 Sobre la caracterización de este grupo puede resultar de interés el artículo de R. Rorty, "Priority of Democracy to Philosophy”, incluido en el volumen Objectivity..., pp. 175-196. 
Este obra forma parte del acervo de la Biblioteca Jurídica Virtual del Instituto de Investigaciones Jurídicas de la UNAM www.juridicas.unam.mx

https://biblio.juridicas.unam.mx/bjv

mino a autores que ya han encontrado alojamiento bajo otros rótulos intelectuales, como es el caso de R. Mangabeira Unger o A. MacIntyre.

Se trata de un movimiento de corte fundamentalmente anglosajón, nacido en Estados Unidos y Canadá, a cuyas universidades pertenecen sus más importantes representantes. En cuanto a quienes son, de lo ya dicho se desprende que es ésta una cuestión complicada de responder. Aunque en general hay un grupo de estudiosos que son catalogados como tales, no todos ellos se reconocen a sí mismos dentro del grupo, sino que los hay que se niegan a ser etiquetados, como es por ejemplo el caso de MacIntyre. Hay un cierto acuerdo en incluir entre ellos a Charles Taylor, Michael Sandel, Michael Walzer y Robert Bellah. ${ }^{41}$ Indudablemente, parte de la relevancia de las críticas comunitaristas radica en que han sido escuchadas y contestadas; autores como Rawls, Dworkin o Habermas en Europa, han hecho eco de su contenido en sus últimas obras, lo cual, por otra parte, no es más que una muestra de lo atinado de sus críticas.

Charles Taylor quizá sea el único de ellos que se autodenomina comunitarista, e incluye dentro del movimiento a otros. Según sus mismas palabras:

En realidad, el término "comunitarismo" es aplicable a pensadores muy diferentes como Sandel, MacIntyre o yo mismo. Considero el comunitarismo como un tipo de liberalismo entre otros. Se inserta en la tradición del pensamiento de Tocqueville, que fue un pensador liberal. Lo que nos aúna es la crítica del liberalismo estandar. Este factor hace que se considere el comunitarismo como un bloque, aunque nuestra ética se hace desde posiciones muy diferentes, desde la izquierda y desde la derecha. ${ }^{42}$

Esto reafirma que la crítica al liberalismo es la nota que unifica a una serie de autores que, por lo demás, tienen bien poco en común. Partiendo de la misma frase de Taylor antes citada, se puede decir que ese algo común es una forma de liberalismo político. Tocqueville no era un liberal en el sentido pleno de la expresión, sino un representante del liberalismo político, un demócrata que abogaba por la igualdad. Dicho de otro modo,

41 Puede hablarse de una segunda generación, consitituida por el grupo de autores, encabezado por A. Etzioni, que tratan de construir el nuevo discurso de la izquierda y cuyos intereses son fundamentalmente políticos, antes que intelectuales. Indudablemente, presentan un menor interés para quienquiera entender los presupuestos filosóficos del comunitarismo. Cfr. Etzioni, A., Rights and the Common Goods: the Communitarian Perspective, New York, 1995.

42 Cfr. Taylor, "Cross Purposes: the Liberal-Communitarian Debate", en Liberalism and the Moral Life, N.L. Rosenblum ed., Cambridge, Mass., London, 1989, p. 159. 
Este obra forma parte del acervo de la Biblioteca Jurídica Virtual del Instituto de Investigaciones Jurídicas de la UNAM www.juridicas.unam.mx

https://biblio.juridicas.unam.mx/bjv

el nexo central del comunitarismo, si existe, es político y social, y es un intento de recuperar la noción de comunidad como central para entender al individuo.

Su importancia es grande en ámbitos muy diferentes. Así, por ejemplo, en lo que hace a la educación, frente a la pretensión liberal de educar al individuo de una forma neutra, como independiente de cualquier contexto, el comunitarismo propugna la necesidad de remarcar el aspecto social preparando al individuo para ser un buen ciudadano a través, entre otras cosas, del fomento de determinadas virtudes cívicas. Aunque la noción de comunidad es externa a la filosofía jurídica (pertenece a ámbitos afines como son la filosofía social o política) su incidencia en lo que respecta al fenómeno jurídico puede ser decisiva en múltiples aspectos. Sin embargo, el contenido de que se dote a tal noción determina más divergencias que semejanzas en el pensamiento de los autores que la sustentan, pudiendo ir desde tesis que apoyan un multiculturalismo atomizador basado en el respeto a la autodeterminación de las comunidades que se alojen en un mismo ámbito estatal, hasta otras que sostienen que el hecho social debe traducirse en un incremento de la fuerza de la dimensión pública sobre la privada.

La primera versión sería la que promueve la toma de conciencia de las diferencias existentes en el seno de una comunidad que, a su vez, puede mantenerse dentro de los límites del monopolio estatal característico del liberalismo, o bien puede dirigirse a mermar dicho monopolio a través de la atomización de las fuerzas sociales. Las opciones van desde el pluralismo liberal de Walzer, que propone apelar a diversas esferas dentro de las cuales se perseguirán distintas nociones de bien, hasta la promoción de diversas formas de nacionalismo o de unidades sociales de nivel inferior al estatal. Podría decirse que esta postura se mueve en el ámbito de las estructuras políticas. ${ }^{43}$

El segundo grupo de tesis lleva al terreno moral y (paradójicamente, por ser denominado con terminología política) constituye las diversas formas de republicanismo dentro del cual también hay divergencias. Algunos proponen una tesis fuerte a través de la vuelta a los valores que inspiraron los derechos en sus formulaciones iniciales como, por ejemplo, la Constitución americana. ${ }^{44}$ Otras formas constituyen más bien una alterna-

44 En este punto destacan las aportaciones de algunos de los seguidores de L. Strauss como T. Pangel. 
Este obra forma parte del acervo de la Biblioteca Jurídica Virtual del Instituto de Investigaciones Jurídicas de la UNAM www.juridicas.unam.mx

https://biblio.juridicas.unam.mx/bjv

tiva a la posición dominante a través de la propuesta de un perfeccionismo por oposición a la neutralidad del poder público. ${ }^{45}$ Se distinguen, en consecuencia, de un comunitarismo atomizador en que, donde uno pone el acento en la disminución del poder centralizado, otro propone una mayor incidencia de lo social por oposición a lo individual. Esto no significa necesariamente un incremento del poder estatal; en concreto, tiene mucho que ver con la recuperación de nociones, como la de sociedad civil y la protección de instituciones y mecanismos previos a los estatales. ${ }^{46}$

El hecho comunitario cambia de significado con la emergencia de la modernidad. En este momento en el que el fenómeno asociativo irrumpe con fuerza según modelos contractuales más o menos voluntarios, en cuya génesis hay una forma individualista de entender las relaciones sociales, incompatible con formas de corte comunitario que quedan aparentemente obsoletas. ${ }^{47}$ La comunidad se convierte así en un hecho residual, al menos en las sociedades avanzadas. Hablar de comunidad o de la necesidad de su pervivencia, podría ser interpretado como la consecuencia de un afán colectivista, o como un sentimiento nostálgico absolutamente trasnochado y sobre todo ineficaz, y en ese sentido peligroso. Pero los comunitaristas ponen el dedo en la llaga al decir que el debilitamiento de la ideología liberal iría en primer lugar por la vía de una crisis de la ideología del progreso, como ponen de manifiesto movimientos actuales como los distintos ecologismos. Pero en segundo lugar, y esto es más importante, guarda relación con la crisis de la razón pura y el individuo abstracto.

En clave de derechos Waldron pone sobre el tapete una de las cuestiones que más perplejidad suscitan en este debate, que es el papel del consenso social en la determinación de los derechos por oposición a la consideración individualista de los mismos. ${ }^{48} \mathrm{El}$ ejemplo en que se apoya es el de una sociedad en la que se plantee una cuestión moral difícil, sin que se pueda decir con claridad de que exista un daño a terceras personas, como puede ser el de la legitimidad de las relaciones homosexuales. Según él, la postura comunitarista apelaría a la concepción moral que sostenga dicho grupo social. Los liberales, por el contrario, consideran que la

45 Una de las más inteligentes es la de J. Raz.

46 Uno de los trabajos más claros acerca de esas distinciones es el de Gardbaum, S.A., "Law, Politics and the Claims of Community", Michigan Law Review, núm. 90, 1992, pp. 685-760.

47 Sobre este tema $c f r$. las tesis de Hayek, siguiendo en este punto a Popper y su noción de "sociedad abierta", en las que distingue entre modos de organización arcaicos y actuales.

48 Waldron, J., Liberal Rights. Collected Papers 1981-1991, Cambridge, 1993, pp. 168 y ss. 
Este obra forma parte del acervo de la Biblioteca Jurídica Virtual del Instituto de Investigaciones Jurídicas de la UNAM www.juridicas.unam.mx

https://biblio.juridicas.unam.mx/bjv

voluntad de la mayoría no puede vulnerar el derecho soberano de libre elección individual. El concepto liberal de derechos se entiende en clave de intereses individuales, con el consiguiente necesario choque de intereses. La clave de la determinación de lo que deba ser prohibido o permitido no puede ser el principio de daño entendido exclusivamente como el no perjudicar los intereses de otro individuo. Evidentemente, la apelación a una comunidad (a una forma u otra de bien común) puede implicar posturas que van de un mayor o menor relativismo hasta alguna forma de objetivismo. Ahora bien, lo que de un modo u otro plantea el comunitarismo, en primer lugar es la imposibilidad de construir un sistema de derechos sobre la base de un individualismo descontextualizado. Los problemas que genera hablar de derechos serían en buena medida obviados si esa categoría se sustituyera por la de bienes. ${ }^{49}$

\section{RECUPERACIÓN DE LA IDEA DE TOLERANCIA. ¿UNA UNIVERSALIDAD POSIBLE?}

La cuestión estriba en si es posible mantener una forma de universalismo ético sin apelar por ello a un universalismo de derechos. ${ }^{50} \mathrm{O}$, al menos, si es posible conservar una forma de universalidad a pesar de haber rechazado un planteamiento racionalista y estatista de los derechos. Ciertamente, los llamados derechos humanos son contingentes y, por otra parte, no hay garantía de que el texto que los recoja sea el que mejor se adecue a su contenido. Eso es una cosa, y otra muy distinta es que no se correspondan con nada real o, dicho de otro modo, que no haya ninguna realidad que nos permita hablar de lo humano como de aquello que "hay" que respetar y de lo que se deducen obligaciones no sólo morales sino también jurídicas.

El problema es visto con mucha claridad por Ronald Beiner, quien lo resume del siguiente modo:

En el fondo de esta cuestión está lo que podríamos llamar la opción "universalismo/particularismo". Optar totalmente por un universalismo implica alienación, falta de raíces. Optar totalmente por un particularismo implica parroquialismo, exclusivismo y una gran estrechez de horizontes. Sin em-

50 Precisamente lo opuesto a la tesis liberal de Rawls que promueve un universalismo de derechos junto a un relativismo en cuanto a la noción de bien. 
Este obra forma parte del acervo de la Biblioteca Jurídica Virtual del Instituto de Investigaciones Jurídicas de la UNAM www.juridicas.unam.mx

https://biblio.juridicas.unam.mx/bjv

bargo, no está claro que sea viable filosófica o prácticamente una síntesis entre la raigambre particularista y la amplitud universalista. En la práctica, y quizá también en la teoría parece que siempre estamos oscilando entre uno y otro extremo. Esa síntesis, que trata de evadir un cosmopolitanismo liberal y un particularismo no liberal, hasta donde sea posible conseguirla, es lo que yo llamo "ciudadanía". 51

Hablar hoy en día de alguna forma de universalidad en los derechos desde un objetivismo ético exigiría, bien volver a las raíces históricas de la Ilustración, o bien proponer otra solución al margen del proyecto ilustrado. Es preciso plantear la cuestión en los distintos ámbitos a los que afecta que son, no sólo el moral, sino también el político y el jurídico. El problema con el que se enfrenta el poder político, así entendido, y el liberalismo, en definitiva, es la determinación de los límites de lo tolerable. Aquí aparece el derecho en su faceta no dispositiva sino protectora, es decir, la más específicamente atribuida a la autoridad por no poder quedar a merced de la voluntad de los individuos, como sí queda, al menos hasta los límites trazados por las necesidades del tráfico jurídico, la vertiente contractual del derecho. Desde este punto de vista, la recuperación del concepto de tolerancia tiene un interés especial, porque implica simultáneamente una recuperación de la razón práctica y la posibilidad de hablar de libertad en la esfera política. Evidentemente, el gobernante no hace al hombre libre, y concederle una esfera de movimiento autónomo tampoco es precisamente libertad. El gobernante sólo puede actuar o conceder, pero no hacer al hombre de una determinada manera.

La modernidad se apoya como en su quicio en la noción de autonomía, fundamentalmente en sus facetas de principio de conocimiento y criterio de especificación de las ciencias y, en este sentido, clave del progreso de las mismas. Pero es también principio de moral desde el momento en que lo que determina la moralidad de un comportamiento es un principio interno y no la sujección a ninguna instancia externa, sea esta del tipo que sea. Y precisamente la autonomía es la que se ve puesta en tela de juicio por el empeño contextualizador, como se verá a continuación.

La traducción política liberal del principio de autonomía ha sido también el principio de neutralidad. La neutralidad es un espejismo, un imposible, y, en términos lógicos, constituye una contradicción. El poder público, el orden social, las pautas de comportamiento en una sociedad, no 
Este obra forma parte del acervo de la Biblioteca Jurídica Virtual del Instituto de Investigaciones Jurídicas de la UNAM www.juridicas.unam.mx

https://biblio.juridicas.unam.mx/bjv

pueden ser neutrales como ha venido comprobándose en los últimos años. No sólo porque necesariamente a través de su política un gobierno incentivará determinado tipo de conductas sobre otras, sino porque la misma pretensión de neutralidad constituye una opción que excluye la neutralidad misma. Una ética de mínimos ya es una propuesta válida, sean esos mínimos tendentes a facilitar un libre mercado o una moral progresista.

El pluralismo en sí mismo no se compadece con la neutralidad, puesto que no es, como ésta, un principio formal sino sustantivo, y pueden incluso llegar a ser incompatibles. El elemento común probablemente está en que no se imponga a todos una noción de bien, pero pluralismo parece sugerir una consideración sociológica por oposición a meramente racional y, en consecuencia, real. Ahora bien, el pluralismo sería susceptible de ser sometido a crítica, ya que en sí mismo no contiene los límites de lo tolerable. Ni siquiera contiene, como los sistemas consecuencialistas, un principio de determinación de lo éticamente correcto. De una base pluralista no pueden extraerse criterios de justicia porque pertenecen a dos órdenes de conocimiento diferentes.

El universalismo abstracto del que habla la tradición kantiana no tiene por qué ser el único existente. ${ }^{52}$ Ahora bien, cualquier propuesta que se haga en este momento no puede prescindir de los cambios que, tanto el pensamiento político y jurídico como la realidad social misma, han sufrido en los últimos tiempos.

En primer lugar, el individualismo liberal ha muerto. No es posible entender los derechos en esa clave puesto que las pautas de comportamiento moral no son consecuencia de una elección individual sino que son, al menos hasta cierto punto y desde una perspectiva aristotélica, determinaciones sociales. ${ }^{53}$ Eso no significa que sean constructos sociales, sino más bien descubrimientos que el individuo no puede realizar en solitario. No por ello es preciso compartir la tesis progresista de Habermas porque el simple hecho de suceder en el tiempo no puede ser garantía de probidad de una tesis, aunque puede admitirse una cierta idea de progreso

52 En realidad, todos los planteamientos filosóficos (salvo los escepticismos extremos) nacen con una pretensión de verdad. Pero eso no significa pretensión de universalidad. Para que un determinado planteamiento se considere universal se ha de partir de una igual consideración de las personas en un aspecto del conocimiento que afecte a todas ellas. Es decir, deben considerarse como iguales al menos en ese aspecto.

53 En este punto es muy importante la aportación de Raz fundamentalmente en The Morality of Freedom, Oxford, 1986. 
Este obra forma parte del acervo de la Biblioteca Jurídica Virtual del Instituto de Investigaciones Jurídicas de la UNAM www.juridicas.unam.mx

https://biblio.juridicas.unam.mx/bjv

si se entiende la moral en clave de descubrimiento personal en un entorno de tradición cultural.

La onda literaria de la posmodernidad ha tenido el mérito de poner de manifiesto lo problemático de un lenguaje descontextualizado acerca del individuo; trasladado al derecho, esto significa que no tiene sentido la pretensión de elaboración de un código perfecto desconociendo la realidad a la que ha de ser aplicado. En pura teoría jurídica afecta directamente a la interpretación de las normas, sean o no escritas. Pero en lo que hace a los derechos humanos si se acepta ese término se ha de aceptar también que esos derechos existen independientemente de un texto y, en consecuencia, la crítica al racionalismo no puede ir por la vía de la interpretación de ese texto, adopte éste la forma que adopte. Es evidente que quien hoy desee hacer revivir el debate iusnaturalismo-positivismo habrá de hacerlo a través de la dicotomía objetivismo-relativismo.

La moral tiene mucho que ver con la práctica social, lo que, como se vio es muy distinto de decir que sea un constructo social o que varíe del mismo modo que lo hacen los usos sociales. De hecho, como bien puso de manifiesto Mill, pueden estar vigentes en una sociedad normas morales que no se correspondan con usos sociales y que, en consecuencia, sean vulneradas sistemáticamente. Ya se ha dicho que las pautas morales no pueden ser elecciones individuales; la moral es una cuestión de práctica real y de cristalización en el tiempo. No puede ser tampoco el resultado de una moda que fácilmente puede sufrir las influencias de agentes externos. La ciencia es incapaz de establecer reglas fijas aunque el carácter finalizado del hombre sí es capaz de percibir los límites de lo tolerable. Hay que aplaudir la idea de hacer frente a la neutralidad a través de una propuesta perfeccionista en un doble sentido: no sólo que la autoridad no puede limitarse a una actividad de control negativo, sino también que la moral misma implica una búsqueda continua. Como diría MacIntyre, vida buena es aquella dedicada a la búsqueda de la vida buena. ${ }^{54}$

En otro orden de cosas, pese a la tradición de los dos últimos siglos, los derechos no necesariamente han de entenderse en clave de derechos subjetivos, es decir, no lo son porque existan vías para su reconocimiento, sino que éstas responden a exigencias previas de carácter jurídico. Cuestión distinta es la de su posibilidad. Sólo hay derecho cuando hay una obligación correlativa (aunque en ocasiones pueda ser difícil identificar al 
Este obra forma parte del acervo de la Biblioteca Jurídica Virtual del Instituto de Investigaciones Jurídicas de la UNAM www.juridicas.unam.mx https://biblio.juridicas.unam.mx/bjv

titular de esta última), y esto sólo puede darse cuando existe objeto de esa obligación. Otorgar categoría de derecho a imposibilidades sólo contribuye a devaluar el concepto de derecho mismo. La mayor o menor capacidad de protección de los ciudadanos por parte del gobernante se manifiesta en los compromisos que asume frente a los gobernados, y sobre todo, a la credibilidad de aquéllos. De otro modo, se tratará de un desideratum, de mayor o menor perfección en su redacción, pero no cabe duda que es peligroso que el gobernante se comprometa a lo que en realidad no puede hacer.

Para abordar la cuestión de cuál es el método de determinación del contenido de los derechos resulta indispensable ver el nivel de conocimiento científico en el que la noción de derechos humanos debe ser desarrollada. Y lo primero a analizar es si nos hallamos ante una categoría moral o jurídica. A oídos continentales esto suena muy extraño, pero no en la teoría jurídica anglosajona, que sí admite habitualmente la distinción entre derechos legales y morales. En cambio, desde una perspectiva continental, si todos los derechos son jurídicos y no necesariamente deben estar amparados en una norma legal, habría que admitir que hay derechos que son previos a la legislación, y, a continuación, discutir si esto implica una forma de objetivismo en cuanto a los derechos o si, por el contrario, sería compatible con formas de relativismo en el sentido de que los derechos se configuran como tales en el seno de tradiciones culturales que, por tanto, varían necesariamente de unos lugares a otros.

La tesis que aquí se sustenta es que si no es posible determinar lo que sea justo para todos los hombres de todos los tiempos sí lo es, en cambio, la determinación de cuál sea la conducta justa aquí y ahora. Ciertamente, el lenguaje jurídico (lo mismo que el lenguaje moral, pero de una forma aún más limitada) no ofrece una sola respuesta para los problemas con que la razón práctica se enfrenta. Pensar de otro modo nos conduciría, dentro del paradigma liberal, a planteamientos hermenéuticos como los de Dworkin. ${ }^{55}$ En cambio, sí es posible delimitar lo que no pueda ser considerado derecho. Podríamos decir, en consecuencia que, no es posible determinar a priori el contenido de los derechos y sí, en cambio, lo que sea justo en el caso concreto aunque la misma naturaleza no sólo práctica 
Este obra forma parte del acervo de la Biblioteca Jurídica Virtual del Instituto de Investigaciones Jurídicas de la UNAM www.juridicas.unam.mx

sino instrumental del derecho permite que ordinariamente las soluciones sean más de una.

\section{BIBLIOGRAFÍA}

“Are There Any Absolute Rights?", en Waldron Therories of Rights, Oxford, 1984, pp. 91-109.

"Cross Purposes: the Liberal-Communitarian Debate" en N. L. Rosenblum (ed.), Liberalism and the Moral Life, Cambridge, Harvard University Press, Cambridge, London, 1989, pp. 159-182.

"Human Rights. Rationality and Sentimentality", en S. Shute y S. Hurley (eds.), On Human Rights, New York, 1993, pp. 111-134.

"Los tres iusnaturalismos", Ars Iuris, núm. 12, 1994, pp. 87-106.

Beyond Objectivism and Relativism. Science, Hermeneutics and Praxis, Philadelphia, University of Pennsylvania Press, 1983.

Equality and Partiality, Oxford, Oxford University Press, 1991.

Objectivity, Relativism and Truth, New York, Cambridge University Press, 1991.

S. Shute y S. Hurley (eds.), On Human Rights, New York, 1993.

The Community of Rights, Chicago, The University of Chicago Press, 1996.

The Morality of Freedom, Oxford, Oxford University Press, 1986.

What's the Matter with Liberalism?, University of Berkeley, California Press, 1992.

AA. VV., Orígenes de la Declaración de derechos del hombre y del ciudadano, J. G. Amuchastegui ed., Madrid, Editora Nacional, 1984.

ARECHEDERRA, L., "Revolución, tecnocracia y demagogia", Persona y Derecho, núm. 26, 1992, pp. 29-50.

ARregui, J. V. y RoDríGUEZ LluESMA, C., Inventar la sexualidad, Rialp, Madrid, 1995.

BAYEFSKY, A., "Cultural Sovereignty, Relativism and International Human Rights: New Excuses for Old Strategies", Ratio Iuris, vol. 9. núm. 1, March, 1996.

BEINER, R., "Introducción”, Theorizing Citizenship, Albany, State University of New York Press, 1995.

BernsteIn, R., "One Step Forward, Two Steps Backward”, recogido en The New Constellation, Cambridge, The MIT Press, 1992, pp. 230-257. 
Este obra forma parte del acervo de la Biblioteca Jurídica Virtual del Instituto de Investigaciones Jurídicas de la UNAM www.juridicas.unam.mx

CARPINTERO, Derecho y ontología jurídica, Madrid, Actas, 1993.

COnstant, B., "De la libertad de los antiguos comparada con la libertad de los modernos", Cuadernos del Pensamiento Liberal, núm. 7, junio de 1987, pp. 67-78.

ETZIOnI, A., Rights and the Common Goods: the Communitarian Perspective, New York, 1995.

FARRARA, A., "Universalism: procedural, contextualist and prudential", en Communitarianism vs. Universalism, Rasmussen (ed.), The MIT Press, Cambridge-London, 1990, pp. 11-37.

FINNIS, J., "Natural Law and Legal Reasoning”, R. George (ed.), Natural Law Theory, Oxford, Oxford University Press, 1992, pp. 135-157.

Gardbaum, S. A., "Law, Politics and the Claims of Community", Michigan Law Review, núm. 90, 1992, pp. 685-760.

GENTZ, F., "Comparación entre la Revolución norteamericana y la Revolución francesa", Cuadernos del Pensamiento Liberal, núm. 2, marzo de 1986, pp. 55-82.

GEWIRTH, A., Reason and Morality, Chicago, The University of Chicago Press, 1978.

GIL CREMADES, J. J., “¿Qué es el derecho natural clásico?”, Temis, núms. 23-24, 1968, pp. 51-72.

Goodman, “Introducción”, Pragmatism. A Contemporary Reader, New York, Routledge, 1995, pp. 1-19.

GunN, G., Thinking Across the American Grain. Ideology, Intellect, and the New Pragmatism, Chicago, University of Chicago Press, 1992.

HABERMAS, J., "Human Rights and Popular Sovereignty: The Liberal and Republican Versions", Ratio Iuris, vol. 7, núm. 1, marzo, 1994, pp. 1-13.

HAYEK, F. A., Los fundamentos de la libertad, tr. de J. V. Torrente, Valencia, 1961.

KRIELE, M., Liberación e ilustración, tr. C. Gancho, Barcelona, Herder, 1982.

Locke, J., Two Treatises of Government, Cambridge University Press, Cambridge, 1988.

MACINTYRE, A., After Virtue Duckworth, London, 1990.

McCARTHY, T., Ideales e ilusiones, tr. A. Rivao, Madrid, Tecnos, 1992.

Mulhall, S. y SwIFT, A., Liberal and Communitarians, Oxford, Blackwell, 1992. 
NAGEL, T., The View from Nowhere, Oxford, Oxford University Press, 1986.

NEGRO PAVÓN, D., Liberalismo y socialismo. La encrucijada intelectual de Stuart Mill, Madrid, Centro de Estudios Políticos, 1975.

NUBIOLA, J., La renovación pragmatista de la filosofía analítica, Pamplona, Eunsa, 1994.

Ollero, A., Positivismo conceptual y derechos humanos, Madrid, Centro de estudios constitucionales, 1986.

PECES BARBA, G., "Los derechos del hombre en 1789. Reflexiones en el segundo centenario de la Declaración Francesa", Anuario de Filosofía del Derecho, VI, 1989, pp. 57-128.

RAZ, J., "Rights and Politics", Indiana Law Journal, núm. 71, 1995, pp. $27-44$.

RoRTy, R., Philosophy and the Mirror of Nature, Princeton, Princenton University Press, New Jersey, 1979.

Rubio CARrACEDO, J., “El ethos posmoderno”, Philosophica Malacitana, suplemento núm. 1, pp. 175-194.

SERnA, P., Positivismo conceptual y fundamentación de los derechos humanos, Pamplona, Eunsa, 1990.

TAYLOR, Ch., "Los fundamentos filosóficos de los derechos humanos. Complemento a la relación del profesor Mathieu", AA. VV., Los fundamentos de los derechos humanos, Barcelona, G. Baravalle, Serbal, 1985, pp. 52-61.

TocQueville, A. de, De la Démocratie en Amérique, París, Gallimard, 1961.

Waldron, J., Liberal Rights. Collected Papers 1981-1991, New York, Cambridge University Press, 1993.

WALZER, M., The Spheres of Justice, New York, Basic Books, 1983. 


\section{ÍNDICE}

Introducción . . . . . . . . . . . . . . . . . .

Ética, legislación y derecho . . . . . . . . . . . . . .

Jorge ADAME GODDARD

Una nueva propuesta iusnaturalista en la filosofía mexicana para fundamentar los derechos humanos . . . . . . . . . .

Enrique I. AGUAYO CRUZ

Los derechos humanos y el fundamento de su universalidad . . .

Mauricio BEUCHOT

Igualdad y simetría: La selección de los derechos

Francisco CARPINTERO

Los derechos y deberes del hombre . . . . . . . . . . . .

Francesco d'AGOSTINO

Derecho y derechos humanos. Introducción a un problema . . .

Joaquín GARCÍA-HUIDOBRO

Los derechos humanos en la lucha política . . . . . . . . . .

Montserrat HERRERO

Los derechos humanos en una época de crisis . . . . . . .

Ilva Myriam HoYOS CASTAÑEDA

El derecho a la vida en la sistemática de los derechos humanos . .

Carlos I. MASSINI CORREAS

Los derechos humanos entre el tópico y la utopía 
¿Sirve el consenso para fundamentar los derechos humanos? Un breve análisis a dos intentos de fundamentación de los derechos humanos desde el consenso (Norberto Bobbio y Chaïm Perelman) . . . . . . . . . . . . . 197 Javier SALDAÑA SERRANO

La evolución del concepto de derechos humanos y sus modernas críticas

Caridad VELARDE QUEIPO DE LLANO 
Problemas actuales sobre derechos humanos. Una propuesta filosófica, editado por el Instituto de Investigaciones Jurídicas de la UNAM, se terminó de imprimir el 14 de diciembre de 2017 en los talleres de Desarrollo Gráfico Editorial, S. A. de C. V., Municipio Libre 175-A, colonia Portales, delegación Benito Juárez, 03300 Ciudad de México, tel. 5601 0796. Se utilizó tipo Times New Roman en 9, 10 y 11 puntos. En esta edición se empleó papel cream book $70 \times 95$ de 60 gramos para los interiores y cartulina couché de 250 gramos para los forros. Consta de 300 ejemplares (impresión offset). 
a cultura de los derechos humanos en México se vio fuertemente reforzada con la reforma constitucional de 2011 . Ésta no sólo impuso una nueva forma de pensar estos derechos, sino que también implicó la más importante transformación en la reflexión jurídica de este país en los últimos cincuenta años.

Los derroteros por donde ha discurrido esta importante transformación han sido muy variados y de índole muy diversa, lo mismo para aquellos que se despliegan en el ámbito práctico a través de los tribunales, que para los que se desarrollan en el terreno teórico; dada la gran cantidad de bibliografía aparecida en los últimos años, unos y otros han tenido como objetivo común asentar la cultura de los derechos humanos en México, que — digámoslo claramenteaún está por consolidarse. Así, hemos pasado de un pobre conocimiento de estos derechos a una euforia por su significado y aplicación, por lo que, como toda euforia, conviene reflexionar maduramente sobre ellos, para que no hagamos pasar por derechos humanos algo que no lo es.

El contenido de esta obra tiene precisamente la pretensión anterior, esto es, ser una propuesta que intenta arrojar luces sobre dos cuestiones trascendentales para los derechos humanos: su significado y fundamento. Así, los autores están convencidos de que sin una buena teoría en la cual soportar estos derechos no se podrá tener una buena práctica, y mucho menos una eficaz protección de los mismos. Ésta es la propuesta esencial del libro, que apareció por primera vez en 1997 y se reimprimió en el 2000. A lo largo de estos años, el libro no sólo no ha perdido vigencia, sino que, por el contrario, va teniendo cada vez más actualidad.

\section{0}

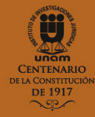

